\title{
Tribes in Modern Yemen: An Anthology
}

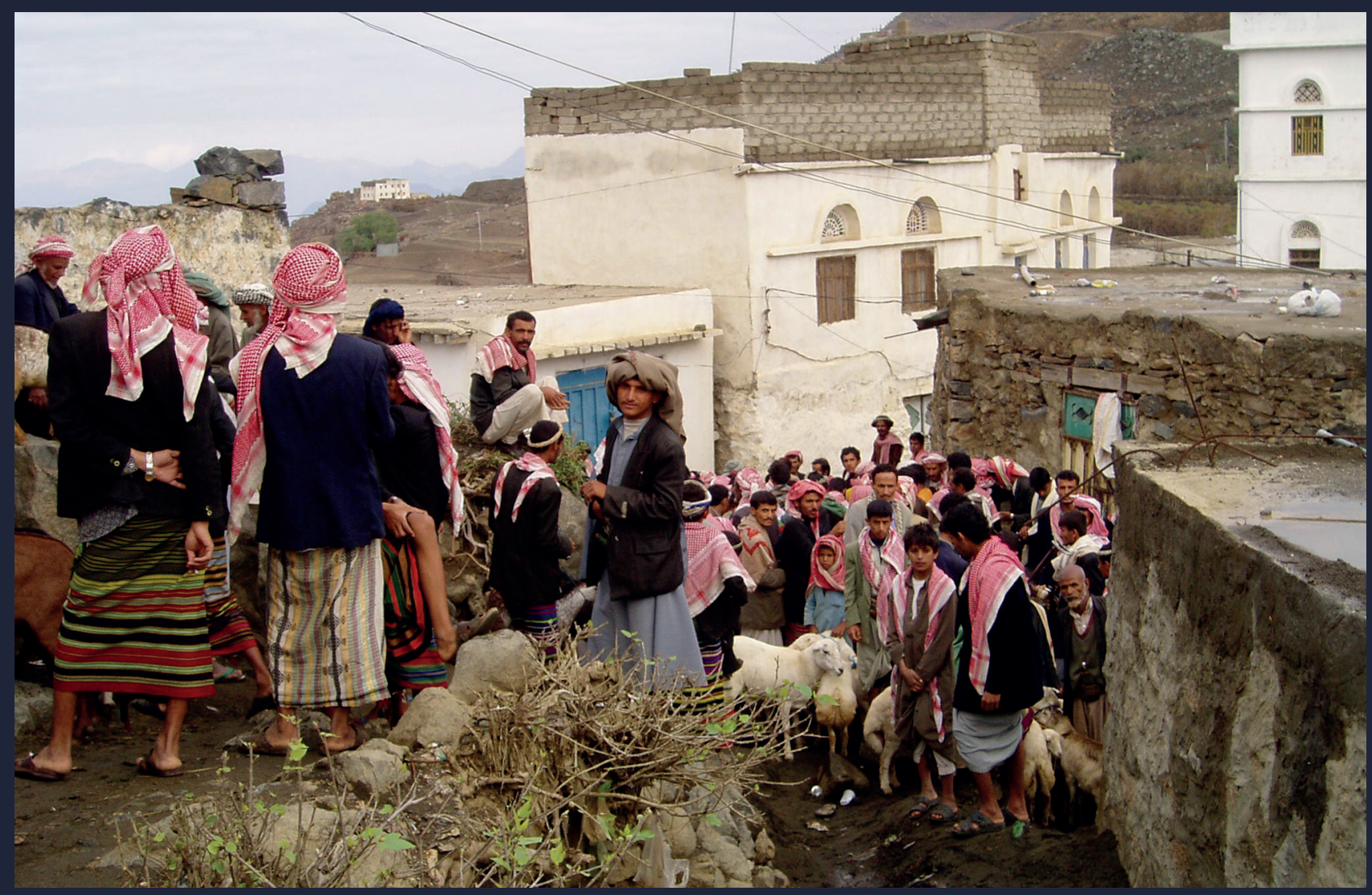


MARIEKE BRANDT (ED.)

TRIBES IN MODERN YEMEN: AN ANTHOLOGY 
ÖSTERREICHISCHE AKADEMIE DER WISSENSCHAFTEN

PHILOSOPHISCH-HISTORISCHE KLASSE

DENKSCHRIFTEN, 531. BAND

SAMMLUNG EDUARD GLASER XVIII 
MARIEKE BRANDT (ED.)

\section{Tribes in Modern Yemen: \\ An Anthology}


Angenommen durch die Publikationskommission der philosophischhistorischen Klasse der Österreichischen Akademie der Wissenschaften:

Accepted by the publication committee of the Division of Humanities and Social Sciences of the Austrian Academy of Sciences by:

Michael Alram, Bert G. Fragner, Andre Gingrich, Hermann Hunger, Sigrid Jalkotzy-Deger, Renate Pillinger, Franz Rainer, Oliver Jens Schmitt, Danuta Shanzer, Peter Wiesinger, Waldemar Zacharasiewicz

Cover photograph: Weekly market in Șa dah province (2006). Back cover photograph: The village of al-Hajjarah (2007); both by Marieke Brandt.

The production of this volume and parts of the research were funded by the Austrian Nationalstiftung FTE in the framework of the New Frontiers Groups (NFG) Programme.

Diese Publikation wurde einem anonymen, internationalen Begutachtungsverfahren unterzogen.

This publication was subject to international and anonymous peer review.

Peer review is an essential part of the Austrian Academy of Sciences Press evaluation process. Before any book can be accepted for publication, it is assessed by international specialists and ultimately must be approved by the Austrian Academy of Sciences Publication Committee.

Die verwendete Papiersorte in dieser Publikation ist DIN EN ISO 9706 zertifiziert und erfüllt die Voraussetzung für eine dauerhafte Archivierung von schriftlichem Kulturgut.

The paper used in this publication is DIN EN ISO 9706 certified and meets the requirements for permanent archiving of written cultural property.

Alle Rechte vorbehalten./All rights reserved.

ISBN 978-3-7001-8619-9

Copyright $(C)$ Austrian Academy of Sciences, Vienna, 2021

Österreichische Akademie der Wissenschaften

Layout: Daniela Seiler, Vienna

Print: Prime Rate, Budapest

https://epub.oeaw.ac.at/8619-9

https://verlag.oeaw.ac.at

Made in Europe 


\section{TABLE OF CONTENTS}

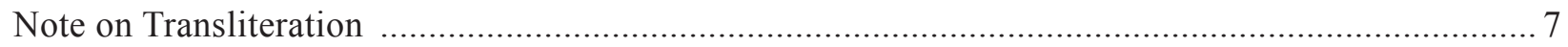

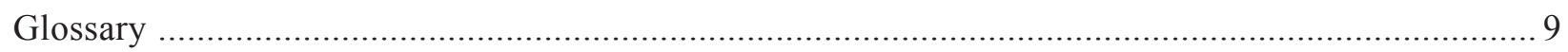

Introduction: The Concept of Tribe in the Anthropology of Yemen

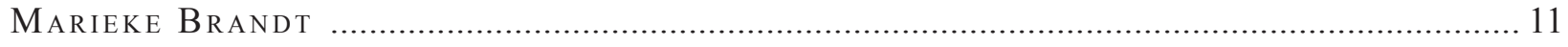

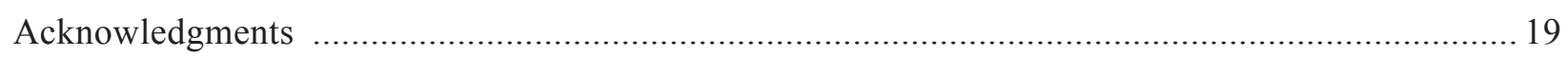

Qabyalah or What Does It Mean to Be Tribal in Yemen?

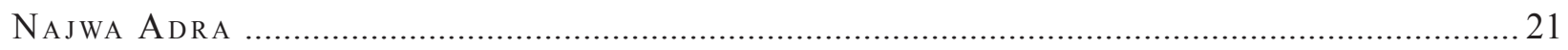

Power as Persuasion in Yemeni Tribal Society

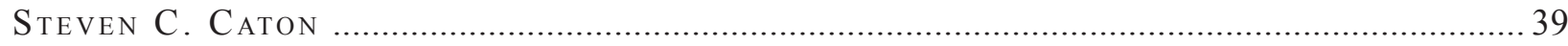

Some Principles and Continuities of Tribal Law

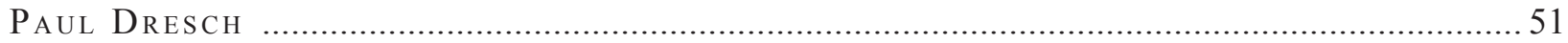

Some Remarks on Blood Vengeance (tha' $r$ ) in Contemporary Yemen

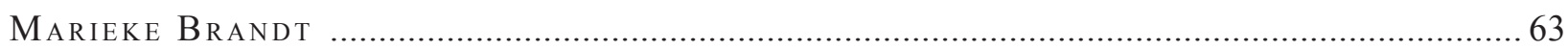

Qabilah, Jirbah and Tanmiyah: Tribes and Agriculture in the Northern Highlands of Yemen

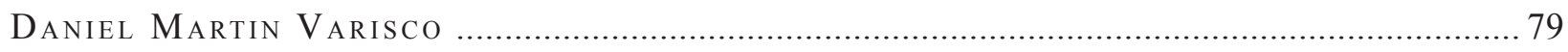

Munebbih's Northwestern Borders Through the $20^{\text {th }}$ Century

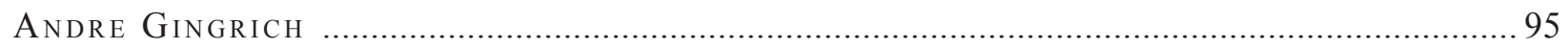

From Bordering to Ordering: The Tribal Factor in Managing the Yemeni-Saudi Border

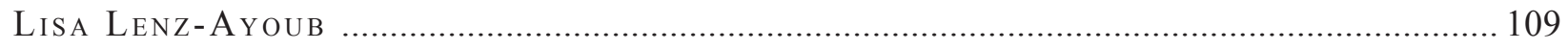

Al-Mawaddah al-Khālidah? The Ḥūthī Movement and the Idea of the Rule of the Ahl al-Bayt in Yemen's Tribal Society

Alexander Weissenburger

Social Restratification in Ḥaḍramawt during the Last 25 Years: An Anthropological Outlook

Mikhail Rodionov

Tribes in the Neo-Liberal Era: Transformation of Yemen's Social Structure

HELEN LaCKNer

Notes on Contributors

Index 



\section{NOTE ON TRANSLITERATION}

For transcribing Arabic, a slightly modified system of the International Journal of Middle Eastern Studies (IJMES) for both written and spoken words has been used. The Arabic t $\bar{a}^{\prime}$ marbütah is rendered $a h$. Initial hamzah is unmarked. Lunar and solar letters remain undistinguished when writing the Arabic article. Common words, such as shaykh, imam, Quran, al-Qaeda, Yemen, Aden, Saudi Arabia, Jeddah, Shiite, Wahhabi, Hadith, etc. are rendered in an Anglicized version. The Arabic bin or ibn ("son of "), where it comes between two names, is often given as simply $b$. The plural of some Arabic words such as shaykh, Zaydī, and Salafî̀ is given in an Anglicized (shaykhs, Zaydīs, Salafīs) version. 



\section{GLOSSARY}

$\bar{a} l$

hijrah

$i b n / b i n$, pls. $a b n \bar{a}$ ' or $b a n \bar{\imath}$

jabal, pl. jibāl

khurüj

madhhab

muhajjar

qabìlah, pl. qaba'il or qubul qabìlì, pl. qabāil

$q \bar{a} d \bar{l}$, pl. qud̄a'

$q \bar{a} t$

sayyid, pl. sādah, adj. sayyid shaykh

'urf, pl. a 'rāf

waqf, pl. awqā $f$

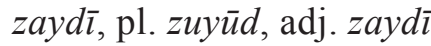

people of; descendants of

person or place under special tribal protection; a settlement or community of $s \bar{a} d a h$ under tribal protection

son

mountain

rising against unjust rulers

school of law

under hijrah protection

tribe

tribesman

hereditary jurist-administrator of tribal descent

Catha edulis forsskål. The chewing of this stimulant plant has a history as a social custom in Yemen

male descendant of the Prophet

tribal leader, representative of a tribal unit

tribal customary law

religious endowment

follower of a branch of Shia Islam whose heartland is in northern Yemen 



\title{
INTRODUCTION:
}

\section{THE CONCEPT OF TRIBE IN THE ANTHROPOLOGY OF YEMEN}

\author{
MARIEKE BRANDT
}

In Yemen, "tribe" (qabīlah) is a historically rooted, emic concept of social representation, even though the polymorphism and ambiguity of the term tribe render the formulation of a universally applicable definition almost impossible. Rooted in remotest antiquity, over the last centuries the concept of tribe in Yemen has undergone transformations, but also featured aspects of longevity and continuity. Today, with the emergence of massive political change, the eruption of popular uprisings, internal conflict, external military intervention and the associated weakness of the state, tribalism seems to be gaining in importance once again, filling in part the void created by the retreating state. It is these present-day expressions of tribalism in Yemen which the chapters of this volume set out to explore.

\section{A Disputed Concept}

There are a number of reasons why it is difficult to work with the concept of "tribe." For historical reasons, anthropology has a special interest in the exploration, but also a specific responsibility for the critical discussion of the concept of tribe. During the period of the Euro-American colonial expansions, the term "tribe" served as a term for societies that were considered "primitive," "uncivilized," or "underdeveloped." At the time dominated by grand theories of social evolution and historical progress, anthropology became a tool to legitimize the rule of the "progressive" societies of the Euro-American area. During the postcolonial era, the concept of "tribe" and the evolutionist world view behind it were critically discussed. As a consequence, the term tribe was widely discredited and abandoned as an analytical term. ${ }^{2}$

A further difficulty consists in the incoherence of the concept of tribe as a sociological term and the associated difficulties of devising a viable definition. In the past, fundamentally different groups from South America to East Asia were freely labelled "tribal," and "tribe" became a kind of umbrella term with little precise meaning. The impossibility of a precise definition, but also the historical (political and ideological) burdens of the term have meant that "tribe" has long been avoided as a social category within Western social and cultural anthropology.

For these reasons, the concept of tribe is no longer considered an analytical term or general comparative category. Much of the scientific discussion focuses on devising a definition of the term tribe that takes into account the differences and varieties in structure and function of such groups in

See, for example, Yapp 1983, 154.

For further details of this ongoing discussion, see the quite different definitions given by Southall 1996; Gingrich 2015; Sneath 2016. Sneath is one of those who are particularly critical of the concept of tribe. He has repeatedly attacked Yemeni scholarship on tribalism and prefers to speak of "principalities" instead. 
different social and political settings, in specific times and regions. Instead of abandoning the term altogether and replacing it with more shallow terms like "community" ${ }^{3}$ or "ethnic group," Gingrich suggests that "an active reformulation where empirically appropriate might be the more productive alternative." ${ }^{4}$ While agreeing that a precise general definition is almost impossible, he advocates for the use of the term as an "equivalent to certain vernacular or national legal terms referring to local conceptions of collective sociopolitical identity." The results are loose working definitions evolving around locally specific notions of belonging, genealogy and descent, territory, collective agency and interaction with the wider world.

\section{Tribes in Yemen}

In many respects, Yemen is a particularly fine example for the emic origin of the concept of tribe. The existence of the principal constituents of the Hamdān ${ }^{6}$ tribal confederation that dominate large parts of highland Yemen - to give but one example - has been proven for pre-Islamic times, and substantial traces of Yemen's pre-Islamic tribal order continued to exist well into the Islamic period. ${ }^{7}$ A comparison with the writings of the $10^{\text {th }}$-century geographer and scholar al-Hasan al-Hamdānī reveals that most (though not all) Yemeni tribes have been sedentary for millennia, and the overwhelming impression is one of minimal change of tribal territories, even if tribal structures have altered or developed from time to time. ${ }^{8}$ In the $20^{\text {th }}$ century, these tribal territories became the basis of the administrative divisions of northern Yemen; the borders of most of today's districts (sg. mudiriyyah) and municipalities (sg. 'uzlah) are congruent with the boundaries of the tribes and tribal sections that inhabit them. ${ }^{9}$ Not only tribal names and structures, genealogies, territories and borders can be traced back over many centuries, but also central principles of tribal customary law ( $u r f) .{ }^{10}$

The tribes of highland Yemen stand out from many other tribal societies of the Middle East also in regard to their recent political history. For centuries, the tribe constituted the organizational unit around which both urban and rural communities converged in Yemen, particularly in the absence of stable centralized states. Before the revolution of 1962, the support of the tribes was the very basis for the rule of the sādah or ahl al-bayt, that is the descendants of the Prophet and pre-republican elite from whose ranks the imams emerged. ${ }^{11}$ Combining the long-existent idea that Yemenis are the "original Arabs" (al- 'arab al- 'âribah) with the genealogical construct that the "true Yemenis" were descendants from Qahțān, the eponym and symbol of unity of the South Arabian tribes, in post-1962 republican Yemen "the tribe" became invoked as the very basis of North Yemeni society.

\footnotetext{
In relation to Yemen, the replacement of the term "tribe" by "community" is propagated by Blumi (2010).

Gingrich 2015, 647.

Ibid.

The grand confederation of Hamdān b. Zayd subdivides into the confederations Hāashid and Bakīl.

Robin 1978, 46-52.

Wilson 1981, 95-96. In some cases, the continuity of tribal names and their related territories spans almost three millennia, see Aston 2014.

$9 \quad$ Matsumoto 1994.

10 On the long-term development of tribal customary law, see Paul Dresch's chapter in this volume.

11 The sādah (sg. sayyid) are the putative descendants of the Prophet Muhammad through 'Alī and Fātimah.
} 
Throughout the $20^{\text {th }}$ century, in many states of the Middle East and North Africa (Iran, Iraq, Libya, Jordan, and Saudi Arabia, to name just a few examples), the relationship between states and tribes was ambiguous and often conflicting, as state authorities manipulated, de- and reconstructed tribal societies in order to turn them into docile tools in the service of the respective government. ${ }^{12}$ This also applies to many areas of southern and eastern Yemen, whose tribes, though historically rooted, have been the target of opposing manipulative policies, first in the course of the British policy of protectorate formation, and later in the PDRY. ${ }^{13}$

In contrast, and compared to the often ruthless interventions of other Middle Eastern governments in their domestic tribal systems, statecraft in northern Yemen left tribalism largely intact. After the September Revolution in 1962, it was due to the physical and ideological weakness of the northern Yemeni republics (YAR and RoY) that - albeit state interference in one form or another was frequent extreme political and ideological manipulations of tribal systems and tribal structures did not take place. After 1962, a system developed in which the republican state (in itself a complicated set of constantly shifting alliances often animated by local and tribal factors) established long-term patronage relationships with tribal elites, without managing to establish consistent control over them. The leitmotif of northern Yemeni state policy towards the tribes was - to give Evans-Pritchard's famous phrase a quite different meaning - that of a "balanced opposition," a kind of equilibrium, a complex bargain between governments and tribes, as competing tribal, religious and political interests agreed to hold themselves in check by a tacit, at times precarious, acceptance of balance. ${ }^{14}$ Today, with the ascent to power of the Hüthīs facilitated by the 2011 "Change Revolution," the war-related tribal mass mobilizations and the disintegration of the state, the relationship of tribes and rulers is again undergoing a process of transformation that in many respects resembles a retrograde step back to the era before 1962 .

The long history of tribes and tribalism in northern Yemen shows that Yemeni tribalism is neither a political or ideological artificially invented concept that has been forced upon the country by foreign powers in order to subjugate and govern local populations, nor a relic of the past whose evolution proceeds vector-like from "archaic" tribes to "modern" societies. The simultaneous presence of various systems and paradigms, and the absence of a teleological sense of history, rather correspond to Khoury and Kostiner's observation that tribes do "not necessarily cease to exist because states were formed." 15 Rather, in highland Yemen, society remains characterized by the permanent but not unchanging coexistence of various paradigms.

12 The studies on state-tribe relations are numerous. See, for example, the chapters in the volumes edited by Khoury and Kostiner 1990a, Abdul-Jabar and Dawod 2003, and Rabi 2016.

13 Bujra 1971; Lackner 1985; Brehony 2011, 69-70.

14 Evans-Pritchard 1949, 59. The term "balanced opposition" is borrowed from segmentary theory, which is regarded as defunct, see Marieke Brandt's chapter in this volume.

$15 \quad$ Khoury and Kostiner 1990b, 2. 


\section{The Chapters}

The collective volume at hand is the result of the workshop titled "Yemen's Living Heritage: Tribes and Tribalism into the $21^{\text {st }}$ Century," which took place in February 2018 at the Institute for Social Anthropology (ISA) of the Austrian Academy of Sciences in Vienna. Its chapters aim at exploring the longevity, liveliness and diversity of tribalism in contemporary Yemen by addressing a broad range of topics, such as the concept of tribe and its historical and present-day dimensions, the changing relationship between tribe and state, the importance of Yemeni customary law and its relation to Islamic and state law, tribal conflict management and conflict resolution, tribal traditions and roles related to territories and borders, agriculture and resource management, cultural practices, and the manifold aspects of social and political change. This volume aims at rethinking and updating research on tribes and tribalism in Yemen, re-connecting the scholarly discourse with the present situation, and providing new input for the discussion of tribalism in the contemporary Middle East.

The first chapter introduces the reader to the concept of tribalness (qabyalah) in Yemen. Qabyalah is a purely Yemeni term and not synonymous with qabaliyyah, which is frequently used to refer to tribalism in the Middle East region. In her article "Qabyalah or What Does It Mean to Be Tribal in Yemen?", Najwa Adra explores the diverse expressions of qabyalah in Yemen and how they play out in everyday life. By reviewing the notions and use of the term qabyalah in various fields - origin, organization, cooperation, customary law, honor, tribal character, work ethics, moral equality, aesthetics, gender roles, etc. - Adra argues that the concept of qabyalah synthesizes the multiple local understandings of tribalism as a moral, social, political, legal, and aesthetic system. Tribal genealogy and descent, while important to some extent, are eclipsed by territoriality and behavior as more important components of identity. Under the onslaught of the turbulent transformation processes of our time, qabyalah proves to be a resilient, but not rigid, concept that is capable of coping with social, economic and political change.

Qabyalah has special notions in the field of tribal leadership whose specific features Steven Caton sets out to explore. In "Power as Persuasion in Yemeni Tribal Society," Caton revisits Khawlān alTiyāl, the site of his initial fieldwork in Yemen in the late 1970s. In the light of what has happened since then, he reflects on the validity of his notion of (tribal) power as consensus finding based on moral suasion, accomplished in large part through communication, especially poetry - an observation that contrasts with more common and dominant scholarly notions of power as a coercive and instrumental force. Caton examines and further sharpens this model through a critical discussion of various theories of discourse and power (specifically those of Foucault and Habermas), before going on to ask what salience this model might have for contemporary Yemeni scholarship, as well as for the future of tribes and tribal leadership in war-stricken Yemen.

In "Some Principles and Continuities of Tribal Law," Paul Dresch explores the features that are at the heart of tribal customary law in Yemen, both in its current and historical forms. By analyzing historical texts and treatises dealing with tribal law in Yemen and comparing them with the present-day contents of customary law, Dresch shows that certain underlying legal principles remain constant for centuries, such as the logic of hospitality, the importance of reciprocal protection and protected space, and the specific "transactional" character that is distinctive for Yemeni customary law. Dresch concludes that tribal law in Yemen is far from changeless but exhibits specific principles that remain consistent for at least seven centuries, down to our own time.

In the following chapter "Some Remarks on Blood Vengeance (tha' $r$ ) in Contemporary Yemen," Marieke Brandt explores the phenomenon of blood vengeance in the tribal societies of highland Yemen. In Yemen's tribal system, the process of taking revenge is governed in great detail by the rules of 
tribal customary law. In recent decades, however, Yemeni statistics observed both an increase in blood revenge cases and their growing non-compliance with the rules of customary law. This chapter argues that the observed increase in revenge cases and their growing non-compliance with tribal customs is caused by societal transformations and, above all, the government's deliberate manipulations of tribal violence that led to a gradual weakening of tribal norms and customs but failed to fulfil the state's obligations to provide an effective apparatus of law and law enforcement able to control violence.

In "Qabilah, Jirbah and Tanmiyah: Tribes and Agriculture in the Northern Highlands of Yemen," Daniel Varisco discusses the historic role of agriculture in relation to tribal identity and tribal customary law against the backdrop of the changes brought about through agricultural development and the current insecurity and open warfare. Throughout history, agricultural activities in highland Yemen were primarily governed by customary law, usually in harmony with Islamic legal principles. For some years, and especially since the beginning of the political, societal and economic transformations brought about by Yemen's "Change Revolution" in 2011, this system has been subjected to a tremendous stress test. In the wake of the current crisis and turmoil, the rural tribal societies of highland Yemen are being forced to cope with dramatic political and economic transformations, in which the set of values embedded in Yemen's qabyalah can help to sustain Yemen's agricultural system and social peace.

The following two chapters deal with tribe-state relations in the area of border management. In "Munebbih's Northwestern Borders Through the $20^{\text {th }}$ Century," Andre Gingrich explores manifestations of state agency and state interventions in Munebbih, a tribe and homonymous area in Yemen's extreme northwest. The importance of this area stems from the fact that some stretches of Munebbih's tribal borders are congruent with the controversial international border between Yemen and Saudi Arabia. Gingrich traces the evolving cooperation process between the Munebbih tribe and the Yemeni state(s) through several stages during the $20^{\text {th }}$ century: first a period of loose contact between the tribe and the state before the mid-1920s, then a phase of beginning but not very close cooperation in the 1930s, and finally, during the Cold War era, a phase of increasing integration of the tribe into the state's efforts to achieve the implementation and protection of its international border. The advancement of state influence from the 1920s until the 1980s mirrors a certain gradually increasing presence in the region by various states, albeit the development was never linear and consistent, but continued to feature fractures and breaks. By reviewing this process, this chapter demonstrates how a focus on tribal borders can reveal other and new dimensions of tribalism and tribe-state relations at large.

In "From Bordering to Ordering: The Tribal Factor in Managing the Yemeni-Saudi Border," Lisa Lenz-Ayoub continues the topic of tribes and border management by paying particular attention to recent developments since the beginning of the $21^{\text {st }}$ century. Lenz-Ayoub shows that the current crisis has led to major changes in the roles and tasks of the border tribes, who have been involved in the guarding and administering of the border from its initial establishment in 1934. Increasing Saudi security concerns, as well as the war raging in northern Yemen, have contributed to the successive formalization, institutionalization and militarization of the Yemeni-Saudi border management at the expense of the long-standing role of the local tribes. Today, with the conflict-induced expulsion of many tribal leaders from the borderlands and the involvement of their tribes in the war, the traditional system of tribal border protection is on the brink of collapse.

Alexander Weissenburger's chapter “Al-Mawaddah al-Khālidah? The Hūthī Movement and the Idea of the Rule of the Ahl al-Bayt in Yemen's Tribal Society" considers another aspect of the current crisis in Yemen, that is the (re)negotiation of the relationship between the tribes and the social stratum of the sādah or ahl al-bayt, the descendants of the Prophet and former elite of the pre-1962 imamate, 
many of whom recently regained power and influence in the Hüthī leadership. Weissenburger analyzes the ideological high-wire act of the Hüthī leaders, who, in addressing their tribal supporters, try to legitimize the re-establishment of the active political leadership and religio-political authority of the ahl al-bayt with recourse to their distinct (foreign) descent, while simultaneously striving to portray Zaydism and Hüthism as indigenous movements, deeply rooted in Yemen. The outcome of this (re) negotiation of the relationship between the tribes and the ahl al-bayt is of great political importance, as it will decide whether the tribes will be willing to support the Hüthī leaders on a permanent basis, beyond the current war.

Throughout the tribal societies of the Middle East, the politics of belonging and processes of identity formation take varying shapes and forms. Mikhail Rodionov's chapter "Social Re-Stratification in Hadrramawt during the last 25 years: An Anthropological Outlook" introduces the reader to the society of the Wādī Haḍramawt in eastern Yemen and, by doing so, also illuminates a specific way Haḍramīs seek to cope with the prevailing rapid social transformation: a return to - and in many ways the reinvention of - tribal genealogy. As such, Rodionov's chapter reveals a seemingly marginal but vital and lively aspect of the Hadrami society, as the most active members of the non-tribal, low-status strata either seek their origin within the tribal context by forging genealogical ties with the "noble" tribes or evade the universe of the social strata by joining radical Islamists. This chapter elucidates the enduring relevance of tribal descent and genealogy and the reasons that compel low-status people to invent their "authentic" descent from Haḍramawt's prestigious tribes.

The last chapter is devoted entirely to the subject of social change. In "Tribes in the Neo-Liberal Era," Helen Lackner presents some of the issues concerning Yemeni social structure and the place of tribes within different approaches to political economy analysis by examining three main trends in Yemen's social transformation in the past half century: First the rise of a new capitalist neo-liberal class, including people of all ascribed social statuses under the Șālih regime. Second, the partial reversal of this trend resulting from the rise of the Hūthīs, who are empowering the sādah or ahl al-bayt as their political leaders, using status ascribed by descent as a rationale for privilege and promotion. Thirdly, it assesses the likely long-term impact of Yemen's transitional period that began in 2011 but has been stalled and overridden by the empowerment of the Hūthīs and the war that began in 2015. Yemen's political transition set in motion a process that addressed issues of representation and led to the political and social recognition of social strata that were increasingly defined by social identity rather than economic interests, such as women, the youth and low-birth-status individuals, but also "civil-society" groups and, to a certain degree, tribes. Against this backdrop, Lackner concludes with an examination of the enduring relevance of the concept of "tribe" in Yemen.

Without in any way claiming to be exhaustive, the chapters of this volume deal with specific case studies of the role and agency of tribes and tribalism in contemporary Yemen. Despite the diversity of these case studies, we can draw two main conclusions. First, rather than being anachronisms or expressions of nostalgia for the past, tribes and tribalism are phenomena that are able to cope with and respond to changing circumstances in their social, political, economic and ecological environments. We see evidence of this in the creative ways Yemeni tribes are dealing with governments and states, in the 
evolution of tribal customary law and its relation to other law systems, the developments in tribal conflict management and conflict resolution, agriculture and resource management, in the dynamic character of tribal genealogies over time and their utilization for establishing and expressing alliance and status, and the liveliness of cultural practices, material culture, popular cultural expressions, aesthetics, etc. These observations correlate to a "dynamic" context of tribalism more than to a purely static context. It is therefore crucial that we do not consider tribe and tribalism as rigid, narrowly defined concepts but rather continue to study the ways in which tribes have evolved and how they manage to adapt to new circumstances and challenges.

Second, despite its ability to change and the impossibility of a concluding definition, tribalness or qabyalah remains an organizing principle, mostly in the sense of giving priority to kinship loyalties and common action with those who are considered fellow tribesmen. Despite - or perhaps because of - rapidly changing environments, the Yemen example shows that tribalism remains available as a principle for organization and mobilization, similar to what Salzman called a "social structure in reserve." 16 Tapper recently suggested that, instead of continuing to look for a concluding definition, it would be more productive to treat "tribe" and "tribalism" as "ideas" or "ideological elements" determining political and social behavior, usually in relation to other ideas to which they stand in relation or opposition, notably the political and economic expediency of the "state" and "rule of law," and the persuasive charismatic inspiration of religious leaders. ${ }^{17}$ And there are signs that in Yemen the tribal matrix - Gellner's "hardy plant of tribalism" - in its manifold forms and expressions was and is able to outlast the political and religious orders evolving around it. This assumption lies at the heart of this volume.

\section{References}

Abdul-Jabar, Faleh and Hosham Dawod (eds.). 2003. Tribes and Power: Nationalism and Ethnicity in the Middle East. London: Saqi.

Aston, Warren P. 2014. "The Origins of the Nihm Tribe of Yemen: A Window into Arabia's Past." Journal of Arabian Studies: Arabia, the Gulf, and the Red Sea 4 (1): 134-148.

Blumi, Isa. 2010. Chaos in Yemen: Societal Collapse and the New Authoritarianism. London and New York: Routledge.

Brehony, Noel. 2011. Yemen Divided: The Story of a Failed State in South Arabia. London/New York: Tauris.

Bujra, Abdallah. 1971. The Politics of Stratification: A Study of Change in a South Arabian Town. Oxford: Clarendon Press.

Evans-Pritchard, Edward Evan. 1949. The Sanusi of Cyrenaica. Oxford: The Clarendon Press.

Gingrich, Andre. 2015. “Tribe.” In International Encyclopedia of the Social \& Behavioral Sciences, $2^{\text {nd }}$ edition, Vol. 24, edited by James D. Wright, 645-647. Oxford: Elsevier.

Khoury, Phillip; Kostiner, Joseph, eds. 1990a. Tribes and State Formation in the Middle East. Berkeley and Los Angeles: University of California Press.

Khoury. P. and J. Kostiner. 1990b. "Introduction: Tribes and the Complexities of State Formation in the Middle

Salzman 1978, 69 .

Tapper 2018. 
East.” In Tribes and State Formation in the Middle East, edited by Phillip Khoury and Joseph Kostiner, 1-22. Berkeley and Los Angeles: University of California Press.

Lackner, Helen. 1985. PDRY Yemen: Outpost Socialist Development in Arabia. London: Ithaca Press.

Matsumoto, Hiroshi. 1994. "The History of 'Uzlah and Mikhlāf in North Yemen." Proceedings of the Seminar for Arabian Studies 24:175-182.

Rabi, Uzi, ed. 2016. Tribes and States in a Changing Middle East. London: Hurst.

Robin, Christian. 1978. "Le problème de Hamdan: des qayls aux trois tribus." Proceedings of the Seminar for Arabian Studies 8:46-52.

Salzman, Philip Carl. 1978. “Does Complementary Opposition Exist?” American Anthropologist 80 (1): 53-70.

Sneath, David. 2016. "Tribe.” In The Cambridge Encyclopedia of Anthropology, edited by F. Stein, S. Lazar, M. Candea, H. Diemberger, J. Robbins, A. Sanchez and R. Stasch, http://www.anthroencyclopedia.com/entry/ tribe.

Southall, Aidan. 1996. "Tribe.” In Encyclopedia of Cultural Anthropology, edited by D. Levinson and M. Ember, 1329-36. New York: Henry Holt.

Tapper, Richard. 2018. “Tribalism in Middle Eastern States: A Twenty-first Century Anachronism?” Middle East Centre Blog, The London School of Economics and Political Science, https://blogs.lse.ac.uk/mec/2018/07/11/ tribalism-in-middle-eastern-states-a-twenty-first-century-anachronism/.

Wilson, Robert. 1981. “Al-Hamdani’s Description of Hashid and Bakil.” Proceedings of the Seminar for Arabian Studies 11:95-104.

Yapp, Malcolm. 1983. "Tribes and states in the Khyber 1838-42." In The Conflict of Tribe and State in Iran and Afghanistan, edited by Richard Tapper, 150-191. London: Croom Helm. 


\section{ACKNOWLEDGMENTS}

This collective volume is the outcome of the workshop "Yemen's Living Heritage: Tribes and Tribalism into the $21^{\text {st }}$ Century," held on 14-15 February 2018 at the Institute for Social Anthropology (ISA) of the Austrian Academy of Sciences in Vienna. The workshop was convened within the framework of the New Frontiers Groups Programmes (NFG) project "Deciphering Local Power Politics in Northwest Yemen," supported and funded by the Austrian National Foundation for Research, Technology and Development for the Austrian Academy of Sciences. The editor gratefully acknowledges the financial support of the funding organization in carrying out the workshop and the production of this volume. With the promotion of this project, both the Austrian Academy of Sciences and the National Foundation for Research, Technology and Development have demonstrated that even in times of war and insecurity, the continuation and advancement of the exploration of Yemen are feasible and necessary. Beyond this, thanks are due to the host institution, the Institute for Social Anthropology, for creating a favorable research environment and for making possible the event that preceded this volume.

Many people have contributed to the making of this volume. My respect and gratitude are expressed to all those who were involved in the process of conducting the workshop and producing this volume, including the workshop's assistants and, above all, the academic contributors to the event and this volume. All of them have demonstrated a great deal of commitment, flexibility, ingenuity and perseverance in advancing Yemeni studies despite the current crisis, which seriously affects and complicates the research conditions for researchers exploring contemporary Yemen that, at the time of writing, became inaccessible to "traditional" ethnographic fieldwork due to armed conflict.

Finally, special thanks are due to Robert Püringer and Ingeborg Lux at the AAS publishing house (Verlag der Österreichischen Akademie der Wissenschaften), who guided the manuscript through the work of publishing.

Vienna, Spring 2021

Marieke Brandt 



\title{
QABYALAH OR WHAT DOES IT MEAN TO BE TRIBAL IN YEMEN?'
}

\author{
NAJWA ADRA
}

What's in a Name? ${ }^{2}$

"Qabyalah" is sharaf" (honor); qabyalah is "așl" (tribal origins/ genealogy). "Qabyalah is 'urf (tribal law) or "shar" wa man'," both of which refer to customary law. One person said qabyalah refers to "al-tanāzul 'alā had," i.e., stepping down rather than perpetuating conflict. Others said simply, "alqabyalah al-dayfah" (qabyalah is hospitality). Some associated qabyalah with tribal heritage, saying the term referred to asläf al-qabā'il (lit., tribal customs or heritage). Others said that "ayyām alqabyalah" (lit. "qabyalah days") refers to the time before effective central government, when tribes did not pay taxes and followed only customary law. At a focus group discussion with shaykhs in Șan 'à', I was told that qabyalah refers to "self-respect" (ihtirām al-nafs) and "respect for women" (ihtirām al$\left.n i s \bar{a}^{\prime}\right)$. These were all responses given to me over the years when I asked Yemenis from a diversity of regions, "What is qabyalah?"4 I have also heard appropriate clothing and demeanor praised as qabyalah. My most poetic response was composed by the late Sayyid 'Abd al-Karīm Muhammad Sharaf al-Dīn from Kawkabān:

'Allim ibnak li-l-shirā'ah wa l-barā'ah

Wa l- 'amal bayn al-zirā'ah

Wa dakhlat al-sūq kulli sā'ah

1 My gratitude, as always, goes to my friends and hosts in al-Ahjur who have been more than hospitable over the years. I thank the Institute for Social Anthropology, Austrian Academy of Sciences for writing support 2018-2019, and especially Andre Gingrich and Marieke Brandt for their encouragement and comments on previous drafts of this chapter. Others who have provided valuable feedback on my work on this topic include Mohammed Jarhoom, Amat Alsoswa, Lucine Taminian, Steven Caton and my husband, Daniel Varisco. My ethnographic research in 1978-79 was funded by a National Science Foundation Grant for Improving Doctoral Dissertation Research. My fieldwork in 1983 was funded by a MEAward, Population Council, and my 2005 field research was funded by the American Institute for Yemeni Studies. Consulting assignments between 1983 and 2005 have also yielded important insights into tribalism in Yemen. Some of the information in this chapter has appeared in my dissertation (1982) and several articles (1998, 2011, 2015, 2016), but this has been reworked and updated.

2 This chapter transcribes dialectical terms as they are pronounced in Yemen. Hence, dayfah instead of diyāfah, mara instead of imra' ah.

3 Qabyalah, pronounced qabwalah in parts of southern and eastern Yemen, is a purely Yemeni term, distinct from the more commonly used qabaliyyah (tribalism).

4 Author's field notes 1979, 1983, 1987, 2005 and CDF focus group, Șan 'ầ', September 2004. 
Teach your son conflict mediation (with an implied pun on poetry), generosity (a pun on bar 'ah dance), agriculture (implying hard work), and frequent visits to the market (in order to remain aware of news and negotiate tribal affairs).

I asked about qabyalah (qabwalah in Yemen's South and East) because it was the most frequently used term I heard in my years of field research among Yemenis who self-identify as tribal, usually with pride, sometimes sardonically when describing questionable or laughable behavior. But what ties these various meanings together? In this chapter, I suggest that qabyalah synthesizes the multiple local understandings of tribalism as a political and legal system, a set of social and behavioral norms, and aesthetic principles. Tribal descent, while important to some extent, is eclipsed by territoriality and behavior as more important components of identity. I also propose that qabyalah is not the only guide to behavior in tribal Yemen but forms one component of a duality that appears to be widespread throughout the Middle East. This duality is not discussed at length in the literature, with the exception of Joseph and Joseph's 1987 study of a similar duality in the Moroccan Rif and my own work (Adra 1982, 1998, 2016). Changes in understandings of qabyalah and potential implications of tribal identity for the development of national identity will be discussed.

I have not always been comfortable with the terms "tribe," "tribal," and "tribalism" as used in anthropology and the media. Too often these terms appear to lump most of the world into a single, "pre-modern" category. In scholarly work and popular understandings, "tribes" are both exoticized and disdained as repositories of "tradition," emotive survivals of a tenderhearted past, or kin-based, irrational advocates of convention, stolidly opposed to "modern" nation states (Adra 2015; for an example of serious misunderstanding from an American leader whom I respect, see Goldberg, 2016). Consequently, many anthropologists argue against using these terms (e.g., Fleuhr-Lobban and Lobban, 2002). Yet no better English term has been proposed to translate the Arabic qabilah (pl. qabä'il) or 'ashīrah.'

Because a large majority of Yemen's 27 million people self-identify as tribal, this is not a category that can be ignored. Over the years, I have come to understand the term, qabillah (tribe) and its variants as referring to indigenous territorial groups that have long co-existed with cities and states. Tribal names have remained consistent over centuries. Some tribal units self-define in genealogical terms but, as is the case elsewhere, genealogies are used flexibly and manipulated to justify new relationships or break off old ones. The vast majority of Yemen's tribes are sedentary agriculturalists with some livestock or engage in fishing along the coasts. Herding is important in the more arid locales. Whereas in the past urban Yemenis did not usually identify as tribal, extensive urbanization in the past 40 years has enlarged the urban population that self-identifies as tribal.

Qabyalah (tribalism) is an all-encompassing Yemeni term that refers to tribal origins, organization, customary law, norms, an egalitarian ethic and aesthetic tribal icons (Adra 1982). ${ }^{6}$ In the words of Muhammad 'Abdallah al-Jawhī, a poet from the Jawhī tribe of Haḍramawt:

Terms such as "clan" and "lineage" highlight genealogy as a primary organizing principle, while genealogy tends to be secondary among Yemen's tribes.

6 In previous work I had framed my discussion of tribalism in terms of values. I thank Andre Gingrich for pointing to "norms" as the more appropriate term. 
He lied who said that al-qabwalah can be met in every valley

It is higher than valleys and black mountains. ${ }^{7}$

This chapter will describe the various facets of tribalism and its antithesis as understood and lived in Yemen in order to explain the implications of tribal identification for daily life and economic and political participation in Yemen. The following sections explore the various components of the Yemeni concept of qabyalah.

\section{Qabyalah as Tribal Origin}

Tribes in Yemen consider themselves Southern Arabs, descended from Qahțān, a son of Noah and brother to 'Adnān, ancestor of the Northern Arabs. This, and membership in a known lineage are sufficient to establish tribal origin $(a s ̧ l)$ and pedigree. Yemeni tribes in the North were historically distinguished from the sādah, descendants of the Prophet Muhammad through his daughter Fățimah and son-inlaw 'Ali ${ }^{8}{ }^{8}$ although there are tribes composed largely of sādah in al-Jawf and the Hadramawt. Also distinguished from tribes were low-status service providers, such as barbers, musicians, butchers, and others who engaged in work historically considered demeaning. Status endogamy remained important in Yemen into the late $20^{\text {th }}$ century. The significance of these ascribed status distinctions has decreased steadily over time due to their legal abolishment after the revolutions in the North (1962) and South (1967) and changing economic conditions that have drawn members of all status groups into similar occupations. ${ }^{9}$ By the turn of this century, cross-status marriage, although not yet common, was accepted by most in the Central Highland Plateau, where I conducted my most intensive field research. As I hope to show below, however, status distinctions, important in urban contexts, were understated in rural tribal villages even in the 1970s. Members of all groups dressed alike, worked and socialized together.

Qabyalah as Tribal Organization ${ }^{10}$

Throughout MENA, tribes are organized into units of increasing size and scope ("segments" in the anthropology literature), with the household (bayt) as the central foundation (Hammoudi 2017; Ibn Khaldun 2015). Because of the widespread use of genealogical idioms, tribes are often described as kin groups. Yet in Yemen and elsewhere, most tribal units are territorial, with kinship terminology providing a metaphor to indicate closeness or distance (e.g., Peters 1967, 262, 279; Varisco 2017, 240). All parcels of land, including tribal territories, grazing land, villages, personal landholdings and sometimes specific trees, are named and their boundaries specified in written deeds. That said, some Yemeni tribes and tribal units, notably in the northern and eastern parts of the country, identify with a putative ancestor as well as territorial boundaries (Dresch 1993b; Weir 2007; Brandt 2014 and 2016; Gingrich 1989).

Al-Sa a b al-Jawhī 2006, 320-321, quoted in Rodionov 2011, 334.

It appears that in Yemen's North, this particular status distinction may have originated with the migration and subsequent rule of sädah in the $10^{\text {th }}$ Century.

9 See Lackner's chapter in this volume.

10 See Adra 1982, 116-133 for details on tribal units and the mutual responsibilities of the members of each unit in al-Ahjur and the Central Highland Plateau. 
Terms given to tribal units differ regionally within Yemen and from those used in other Arabicspeaking countries. In Yemen's far north, for example, units may be distinguished as fractions, e.g., thulth (third), khums (fifth), thumn (eighth), or parts of the body (Brandt 2014; Dresch 1993b; Meissner 1986; Varisco 2017; Weir 2007). Even where units are defined genealogically, however, their boundaries are territorial. The following describes the most commonly used units in Yemen's Central Highland Plateau, specifically al-Ahjur basin. Unit terminology here is relatively straightforward, genealogical at the levels of household and lineage but otherwise territorial.

The household (bayt) usually consists of three generations of kin but may also contain more distant kin or unrelated single or widowed individuals without a household of their own. In al-Ahjur, the household is also known as daymah, the local term for a small room or a woman's cooking area or kitchen. Those who share a kitchen and usually eat together are defined as a household, with the oldest male member considered its leader. Multiple daymahs may share a large house with several kitchens.

The next unit, called a lineage in this chapter but locally known as lahm (with connotations of cleaving or holding together) or habl (lit. rope or tie), includes several households that share a common ancestral name. This group may also include members who migrated to the area a few generations ago. They do not claim to share the same ancestry but were "adopted" into the lineage. If a lineage grows too large to manage easily, it splits into two or more lineages. ${ }^{11}$ Each lineage selects a leader ('âqil in al-Ahjur) who resolves disputes within the group and represents its interests in discussion and debate with other lineages.

Larger and more important than the lineage is the village (mahall), ${ }^{12}$ a bounded territory that includes pasture, access to water and rocky outcroppings considered suitable for housebuilding. ${ }^{13}$ These resources are available to all village residents. However, villagers do not own agricultural land in common, and individuals may own property outside village boundaries. Although a village is defined purely in terms of residence, people often say of their village, "We are all one family," reflecting the reality that families in a village tend to be related due to a preference for village endogamy. Villagers elect a leader who mediates disputes within the village and represents the village in its dealings with other villages, and sometimes the national government and external parties. In al-Ahjur, a village leader is known as shaykh, although elsewhere he (almost always a man) may be known as 'äqil or by another term. Shaykhs and 'àqils lead as primi inter pares without coercive powers. Wisdom, mediation skills and modesty are among the most desired traits in a leader. Village rules and policies are decided by the heads of lineages together with the village shaykh. A cluster of neighboring villages may form a single political unit, sharing a shaykh and responsibilities for protection and cooperation activity (Adra 1982).

The tribe (qabilah) is the next larger unit in the Central Highland Plateau, where this term refers to a bounded territorial unit comprised of a number of villages, water sources and grazing land. ${ }^{14} \mathrm{Al}-$ Ahjur, the site of my most intensive field research, is locally classified as a tribe, loosely connected

11 Descent groups, often called lineages, have continuity over time and may maintain ties and identify with descent groups of the same name who live elsewhere and thus belong to different tribes.

12 Mahall is used in this part of Yemen, but elsewhere qariyah may refer to village.

13 When agriculture was the primary source of subsistence, rural Yemenis did not build houses on arable land, which was considered too valuable to waste on houses. Since the decline of agriculture in the 1980s, however, an increasing number of houses have been built on previously farmed land.

14 Among transhumant herders, tribe may refer to a large area to which they have grazing rights. 
with Banī Mațar, its closest neighbor. However, it is officially classified as a subdistrict ( $u z l a h$ ), of the administrative district (mudìriyyah) of Kawkabān. ${ }^{15}$ Together, the villages of al-Ahjur elect a paramount leader, known as shaykh al-mashayikh. ${ }^{16}$ Paramount shaykhs may be chosen from among candidates with good urban and government connections in the expectation that they will help direct resources to their constituency. The largest tribal unit, the confederation, rarely acts in concert. Al-Ahjur technically belongs to the loose confederation of Bakill. Wider in scope than the confederation is the North-South distinction noted above.

\section{Qabyalah as Cooperation: The Mutual Responsibilities of Tribes and Tribal Units}

Members of tribal units at all levels owe each other specific responsibilities. As the only unit that shares property in common, the household expects its adult members to contribute to feeding and housing the unit and otherwise helping when needed. These responsibilities are assumed but cannot be enforced by anyone outside the household because behavior among close kin falls outside the jurisdiction of tribal customary law. The members of a lineage do not own property in common, but they owe each other help with meeting the requirements of hospitality and other tasks too difficult for a single household to manage (Gingrich 1989). I witnessed a telling example at a wedding in 1979. Soon after I arrived, I left the dance space with another guest to greet the women of the family who were preparing food for the guests. We stopped at the kitchen door where six or seven women were busy baking bread. They welcomed us, but when the groom's mother noticed my companion, she declared, "Greetings my mother's sister's son's wife, come in and knead dough with us." The young girl, who was dressed for dancing, reluctantly admitted, "True, I am the wife of your mother's sister's son" and went into the kitchen to help with the baking (Adra 1982, 133). The failure to honor required obligations (lawäzim) is considered serious.

Responsibilities at the village and higher levels include protection of their territory and of vulnerable persons within this territory. ${ }^{17}$ They also involve participation in conflict resolution and in community projects. In the past, when raids from neighboring regions threatened grain harvests, all of the village households would harvest crops in unison. In case of conflict within a village or between two villages, the entire village participates in the ensuing discussion and mediation to resolve the conflict. The cost of reparations due from the culprits (usually the slaughter of an animal and a monetary fine) are shared by all households in the village(s), while the victims' village(s) shares in the meat provided as reparation. In practice, however, the village is primarily the locus of cooperative activity and the preferred source of marriage partners. ${ }^{18}$ Typically villagers are called to help with building and repairing infrastructure, schools,

15 Nevertheless, village shaykhs of al-Ahjur receive small stipends from the Directorate of Tribal Affairs, as do other shaykhs and tribal leaders in Yemen.

16 When, in the 1970s, the villages were not all able agree on a single paramount shaykh, two were elected, each representing part of the territory.

17 I use the term "vulnerable" rather than "weak," the usual translation of $d a$ ' $\bar{l} f$ ( $\mathrm{pl} . d u^{\prime} a f \bar{a}$ '), the term most frequently used to refer to people owed protection. Protection is owed not only to the unarmed population but also to strangers and guests, including visiting tribal leaders, who are far from weak in their own territories, and members of specific minorities under tribal protection (see also Gingrich 1989, 132).

18 Village endogamy is usually explained by the reluctance of young women to move far away from their mothers. 
mosques, health centers, cisterns and wells. Major projects are organized by the village shaykh and require the labor of a member of each household or a laborer's daily wage if a household cannot contribute labor.

Despite the current warfare, violent conflict is usually rare in Yemen, and tribal units are mobilized primarily for community development and the resolution of conflict between individuals. ${ }^{19}$ Although the constituents of each unit are usually established, the number of people called to help with any given task varies with the situation and need. Smaller groups are called to work on projects that require the aid of fewer people. Activities requiring the cooperation of several villages or of the entire tribe are organized by consensus among village leaders. Built into the system is a flexibility that allows individual and group behavior to adapt to the context and to changing circumstances. Tribal organization, then, is based on sophisticated and flexible organizational principles that enable groups of varying size to mobilize quickly and effectively to protect their territory and accomplish particular tasks. Tribal units are best defined as cooperative units, made up of ever-expanding units, each with its own elected or selected leaders (Adra 1982, 2015, 2016).

In Yemeni terms, to be tribal and possess qabyalah, is to be ready to help whenever help is needed, to understand which circumstances require one's help and to expect similar aid from others. Also expected from tribesmen is active participation in community and tribal affairs. It is often assumed that "group feeling" or "sentiment" ( așabiyyah), based on real or fictive kinship is the basis of "tribal cohesion" (Ibn Khaldun 2015; Black-Michaud 1975; Robertson-Smith 1990, 1, 30). Considering the pre-eminence of cooperative activity in Yemeni tribal life as described above, I suggest that tribes and tribal units are held together not by chauvinist sentiment or allegiance to a leader but by the contractual obligations implied in the system of ever-expanding tribal units or segments. Individuals who leave the community permanently and cut their ties are no longer expected to contribute. Competition between tribal units is also typical. Tribal icons serve to distinguish tribes from each other by headdress, forms of dancing and poetry, and dialects. Villages often distinguish themselves from their neighbors with their own dances and dialectical variations. More recently, some villages have established rules of women's seclusion that differ from tribal traditions or the practices of their neighbors.

\section{Qabyalah as Customary Law ${ }^{20}$}

As noted at the beginning of this chapter, tribal customary law ('urf, shar' wa man', aslāf al-qabā'il) is often perceived locally as synonymous with tribalism. The focus of tribal customary law is conflict resolution through mediation and consensus. Conflict often involves access to scarce resources - water, agricultural property, prime grazing territories. Other frequent sources of conflict include failure to fulfill responsibilities of protection or hospitality, damage to someone's person or property, physical violence, threats of violence and breach of contract. Due process is a paramount concern, with the facile use of force highly sanctioned. ${ }^{21}$ It is significant that one of the responses above to "What is qabyalah?"

19 This and other information I have collected from the field and written sources refute the prioritization of violence attributed to tribal segmentation in Salzman (1978), Meeker (1979) and Black-Michaud (1975).

20 See Adra (2011) for detailed case studies of conflict resolution in Yemen.

21 This norm is enforced from early childhood. Whenever children come to blows, any adult present will physically separate them. Whenever a quarrel between two adults (especially men) becomes heated, they will both shout loudly at each other with the expectation that others within hearing distance will rush in to keep them separate (see also Weir 2007, 42). 
noted "stepping down" (al-tanāzul) rather than perpetuating a quarrel. Customary laws are based on restitution rather than punishment.

Conflict at all levels is mediated by a third party with the goal of establishing consensus and restoring the self-esteem of the aggrieved person. These range from informal mediation within a household and conflicts between married couples to conflict within tribal units and between tribes. ${ }^{22}$ With personal quarrels between two people, this may involve a small gift to atone for an insult. With more serious conflict involving violence or the threat of violence, the entire unit (often one or several villages) participates in debating the alleged behavior of each disputant, a process that may take several days. Generally men meet together, while women meet at a nearby venue to discuss the case (see Adra 1982, 2011). ${ }^{23}$ In the evenings, the discussion continues at home. When men return to the formal deliberations the next day, they bring with them the input of their mothers, wives and sisters (Adra 2011, 3). After consensus is reached, parties deemed guilty are fined reparations that involve cash and/or the sacrifice of an animal. The entire unit to which the culprits belong shares in the expense of the reparations, while the victims' units share in the spoils. Mediators and others impacted by the conflict also receive shares.

The proceedings of each case, however small, are written and stored with the tribal leader, thus providing legal precedent for future cases. All tribes in Yemen possess written documents detailing previous cases, some of which date to previous centuries (Dresch 2006; Weir 2007). Successful mediators, including women, are highly respected, although women mediators often work behind the scenes by convincing parties in conflict to submit to arbitration (Al-Dawsari 2008) ${ }^{24}$ Disputants unhappy with a verdict may pursue the case at a higher tribal level or in government courts. Some intractable cases have been mediated by the former president (but see Brandt in this volume for other cases perpetrated by the government). The highest respect in tribal society is accorded to maräghah, specialist mediators intimately familiar with customary law who consider cases of last resort.

In theory, the village and tribe are perceived as unified wholes in disputes with other villages and tribes, ${ }^{25}$ and a dispute between a resident of al-Ahjur and a member of another tribe involves the entire two tribes. In practice, however, only the families or lineages directly involved join in the conflict and its resolution. Members of the community who have personal alliances or affinal relationships with members of the opposing group serve as liaisons and participate in the mediation process (Adra 1982, 175-177). Feuding is rare among agricultural tribes in the Central Highlands Plateau, especially those watered by permanent springs, but it appears to be more common among tribes on arid land (see Brandt in this volume).

Based on mediation, customary law is restorative, transparent, and locally accessible (Adra 2016, 327). It prioritizes due process and non-confrontational means of expressing anger, often through carefully crafted verse that synthesizes grievances, as Steven Caton $(1987,1990)$ has shown. Customary law is adaptive. Because it has not been formalized, despite efforts to do so over the years, customary

22 In contrast to village and tribal disputes, household and marital disputes do not involve the entire community (Adra 2011).

23 In some cases, older women join men in these discussions (Gingrich 1997). For similar practices among Omani pastoralists, see Chatty 1996, 147, 148.

24 Although much of women's political participation and mediation is informal, it is highly valued and respected locally.

25 In the past, when security was a more serious threat, villages were fortified, and houses were elevated. Living areas were all placed on higher floors. Their windowless lower floors contained regularly spaced small port holes. 
law remains sufficiently flexible to consider extenuating circumstances in any given conflict, and specific rules are amenable to change. In al-Ahjur in the early years of this century, for example, rules specifying reparations for $q \bar{a} t$ thieves were amended to take into consideration changing economic conditions (Adra 2011, 5).

Customary law has maintained security in the rural areas of Yemen for centuries, always in coexistence with urban and religious legal systems, and it continues to maintain security in most parts of Yemen, including conflict zones. State courts in rural areas are understaffed and expensive, and thus do not provide viable alternatives to mediation. When a dispute is taken to a state court, there is a high risk that both parties will be imprisoned, with the burden of feeding them falling on their families, and cases often take months before they are heard.

People being human, there have always been violations of customary law procedures and rules, often leading to long term feuds in areas susceptible to feuding. But severe violations appear to have increased, or they may be reported in the media more frequently than in the past, leading to public censure of tribalism as an institution rather than of the individual criminals responsible for these breaches. Thus, customary law in Yemen articulates principles of tribal identity and honor as discussed in the next section. When a tribesman or woman characterizes qabyalah as law, they mean that legal prescriptions to control their temper, follow due process in resolving disputes and accept reparations rather than pursuing vengeance are all part of what it means to be tribal.

\section{Qabyalah as Honor}

Behavior locally considered honorable (sharaf) includes courage, adherence to one's word (wijh), generosity, integrity, perceptiveness, industriousness, self-restraint during conflict (highlighting the prioritization of due process) and modesty (especially on the part of leaders). Obligations of hospitality are crucial to tribal honor in Yemen, and hospitality is an icon of generosity and protection. This focus on responsibilities towards others reveals significant differences between Yemeni conceptions of honor from those described in the Mediterranean (e.g., Peristiany 1965) and resembles most closely descriptions in Farès (1932) and Lancaster and Lancaster (2011). ${ }^{26}$ In contrast to tribal honor elsewhere in MENA, women are not conceived of as devoid of honor. Women play important roles in ensuring hospitality which reflect on their own honor and that of the men in their households. ${ }^{27}$ The strict constraints to mobility found in the Levant in the name of honor were not traditionally found in rural Yemen. ${ }^{28}$ "A woman with honor (sharaf) can be with a thousand men [without losing her honor]" is a frequently heard aphorism. Honor killing, presumably in response to women's sexual transgressions, was unknown or extremely rare among Yemeni tribes. Honor killing contradicts both the requirement that men protect women under all circumstances and the legal prohibitions against impulsive violent behavior. Although poetry and legend conflate tribal honor with heroism, honor is not glorified locally. In daily life honor simply refers to proper comportment.

See also Dresch's chapter in this volume.

See Gingrich (1989) for an extensive discussion of the rules of hospitality in tribal Yemen.

Urban women historically faced more constraints to their mobility than rural women. 
Qabyalah as Tribal Character and Integrity ${ }^{29}$

I have been surprised over the years by the consistency with which qabyalah is described by tribal leaders from diverse regions in Yemen as denoting tribal integrity. The following, by Aḥmad Muḥammad Jibrān from Rāziḥ, whom I met in London in 1984, is typical: ${ }^{30}$

Al-qabìlī yitarajjal fì l-harb.

Al-qabīlì mitfarris; yitfarris bi-l-nās.

Al-qabìlì ya 'mil țayyib dā'iman.

Al-qabìlì lā yudrub mara mahmā ta 'mil aw qālatlah.

In time of war, a qabill goes to the forefront of the fighting. The qabill is discerning and perceptive, i.e., he scrutinizes people with a clear awareness of personalities and the situation. ${ }^{31}$ A qabìli always does good. A qabīlī never strikes a woman, no matter what she does or says to him.

Variations include: "A qabīlī does not cheat or deceive (mā yikhtansh), nor does he seek evildoing, such as lying, cheating, violent behavior" (lā ysìr fì mahrat al-bațālah). ${ }^{32}$ "Someone with honor who possesses character and integrity" (Muhammad 'Alī al-Ḥammāmī of Hijrat al-Ahjur, 1983). In the early $20^{\text {th }}$ century, Le Comte de Landberg wrote that to say someone has qabyalah is to imply that "they honor the stranger and do not attack his belongings" ( 'indahum qabyalah y 'izzūn al-gharīb mā yit 'addūn fí al-māl haqqah) (1901 (1), 682, cited in Adra 1982, 140).

Similar presumed characteristics of tribesmen in Yemen, although not the term qabyalah, are found in the Arabic historic literature. The $10^{\text {th }}$-century Yemeni historian al-Hamdāni praised the nobility of the tribes of Hamdān, a category that would include present-day al-Ahjur, eulogizing their roles as protectors of the vulnerable:

Wa ahluhu anjad Hamdān wa hamāt al- 'awrah wa man 'at al-jār

(1884, 194, also quoted in Rossi 1948, 9).

And his people, the most intrepid of [the] Hamdān [tribes] protect the deficient and defend the fugitive. (As is common in Arabic poetry, this line is replete with puns. "Anjad" implies "supportive" and "helpful" as well as "intrepid". The term "man"," translated here as "defend," is also a term denoting customary law.

The $9^{\text {th }}-10^{\text {th }}$-century historian and geographer al-Mas ' $\bar{u} d \overline{1}(1965,236)$ also praised the tribes of Hamdān using terminology of honor that would be familiar to contemporary Yemenis:

See Adra (1982, 144-146) for more detail on this topic.

30 My thanks to Shelagh Weir whose hospitality during this visit encouraged a fruitful 3-way discussion on tribalism in Yemen.

31 Words derived from the root, $f-r-s$ may have connotations other than acute perception, including horsemanship and chivalry. The translation used here is that of the tribesman who quoted these qualities to me. Another way to talk about the perceptiveness of $q a b \bar{a}{ }^{\prime} i l$ is to say, "A qabìlī has red eyes" (Amat Alsoswa, personal communication).

32 Adra field notes. 
Abnä' al-layl wa ahl al-nayl

Wa yuwwafün bi-l-dhimār

Sons of the night and people of action

And hand over their cherished possessions yumna 'ūn al-jār

wa yuṭlibūn al-tha'r

[They] protect the fugitive

And demand justice and restitution

Yemeni friends explained this verse as follows:

"Sons of the night" refers to the courage of tribesmen who are not afraid of traveling at night. Tribes are "people of action" in that they do not hesitate to do what is right. The protection of the fugitive, implying all who are vulnerable, is a fundamental obligation of tribes. Generosity, like hospitality, is a tribal norm (this line has also been translated as "meet their debts."). Tribesmen demand justice and restitution for serious infractions of customary law.

Landberg (1901 (1), 682) concurs: "To say that someone has qabyalah (fulān șâhib al-qabyalah) is to say that he is courageous and possesses tribal pride."

Character and integrity are considered even more revealing of tribal identity than origins, as expressed in the following proverb: Idhā yghurrak al-așl mā yghurrak al-fi'l (If you are duped by someone's [pretended] origins, their behavior will establish the truth.) Someone who consistently fails to fulfill tribal expectations may be referred to as lacking in qabyalah (qalīlat al-qabyalah). A person who consistently flouts tribal laws or ignores the mutual responsibilities that define tribal ties will be said to have left tribalism (qad kharaj min al-qabyalah).

\section{Qabyalah's Work Ethic}

Historically, most $q a b \bar{a}$ 'il worked in highland agriculture, herding or artisanal fishing. This work was and remains physically taxing, and hard work was highly valued and associated with piety (Adra 1982, 151). When I asked people at work what they were doing, a frequent response was, "bi nuqșud Allāh" (We are pleasing God). Women would often say, "We complain about fatigue, but it is the road to heaven" (Adra 1982, 151). Even wealthy qabā'il who could afford to hire labor to cultivate their fields tilled the land along with hired laborers. Until the late 1980s, qaba' 'il also played hard, with weddings and other celebrations lasting for days of continuous dancing late into the night. As the economy has become monetized, and food imports have undercut agriculture, this work ethic is no longer so visible in daily life nor so easily detectable among young Yemenis. Nonetheless, industriousness remains an ideal.

\section{Qabyalah and "Moral Equality"}

Underpinning qabyalah is an assumption of "moral equality" (Dresch 1993b, 50). The model for governance is participatory and egalitarian rather than a centralized hierarchy. Despite the existence of established hierarchies among some tribes in which leaders are selected from specific families, tribal leaders in Yemen have long been considered primus inter pares, and modesty is admired in leaders. 
Historical status distinctions described in the literature include an urban elite, the tribal majority and a variety of low-status service providers who were not historically recognized as tribal. ${ }^{33}$ Yet these status distinctions are understated and often challenged in daily life (Adra 1982, 65-82). In Yemen's North, especially in rural villages, people of all status groups work together, share meals around a common dish, attend celebrations together and dress alike. In rural and urban Yemen, it is common to find highstatus hosts serving lower-status guests, and paid household help (technically of lower status) seated among guests and hosts. ${ }^{34}$ Some tribal families, although by no means all, openly disdained low-status service providers, but whenever I heard a woman deride a mzayyinah (low-status musician), someone else would inevitably reprimand the speaker, stating "Al-mzayyinah tirhim" (mzayyinahs deserve our compassion).

In the 1970s and 1980s, rules of status endogamy were strict, reflecting the relevance of tribal descent. By 2005, cross-status marriage was accepted by many, and I was informed of marriages between tribes and urban elite on the one hand, and tribes and former service providers on the other. In another indication of assumed equality among traditional status groups, I was told that one of the new village shaykhs elected at the turn of the $21^{\text {st }}$ century was a member of a historically low-status service category. When I asked how a member of this status group could become a shaykh (a near impossibility according to the previous literature on tribes in Yemen) my 'äqil companion replied, "Najwa, $m \bar{a} h \bar{\imath}-l$ qabyalah?" ("Najwa, what is qabyalah after all?" - Did I not know that all are equal in a tribal system?)

\section{Tribal Icons: The Aesthetics of Qabyalah}

A number of expressive forms serve as tribal icons. These include bar' $a$ h, the signature tribal dance performed by men in much of Yemen. Each tribe performs its own variation of bar' $a$ h, and until the late 1990s bar'ah performance enacted the intense cooperation that holds tribal units together (Adra 1982, 238-288 and 1998). The basic step is relatively easy to perform, but a successful performance requires perfect coordination among numerous dancers following a very fast beat (Adra 1982, 1998). Bar'ah was strenuous, and bar'ah events typically lasted several hours. Along with bar'ah, zämil is a poetic genre closely associated with tribes (Caton 1990). Both bar 'ah and zammil are performed on occasions when a tribe or tribal unit wishes to present itself to the outside world (Adra 1982, 1998). Reinforcing tribal egalitarianism, any man, whether from the community or visiting, is, in principle, welcome to participate in iconically tribal behavior, such as conflict mediation, tribal dances and poetic composition. Whenever I have asked why men not recognized as tribal participate in the bar 'ah dance that is defined by all as "tribal," I have been told, "status distinctions are erased in bar 'ah." Other tribal icons are also male prerogatives. They include the dagger sheath and rifle worn by tribesmen and increasingly by men who did not self-identify as tribal in the past. Dagger sheaths and headdress, like tribal dances and poetry, distinguish tribes and regions from each other. Other traditional icons of tribalism include land ownership and robust but simple rural foods, not necessarily limited to men (Adra 1982, 1998).

Until the 1980s, pariah groups known as akhdām were absent and largely unknown in the rural North.

34 This behavior differs starkly from elite attitudes in some other countries in MENA in which the elite would not consider eating at the same table as the household help. 
The Male Representation of Qabyalah

Although neither women nor men monopolize honor as understood in Yemen, a male public persona characterizes qabyalah, as is clear from the discussion above of tribal leadership, legal process and tribal icons. Men represent the tribe or tribal unit in all formal proceedings. Men preside during formal conflict resolution, although women play important roles in the process as well as in informal mediation. All legal systems in Yemen - tribal customary, Islamic, and State - assume a woman's dependence on her male kin. Thus, women's male kin represent them in all dispute resolutions. The active participation of a woman's kin potentially provides an important source of support. However, women's (and unmarried men's) recourse to justice is limited if they do not have the support of their male kin (Adra 2016, 316).

\section{Formal Ideology and Its Antithesis}

Qabyalah, with its focus on cooperation and self-restraint and heavy load of responsibilities, is a formal ideology that idealizes tribalism and provides a standard for comportment in public, but it does not cover all that is important to Yemen's tribes. Qabyalah coexists with a wide range of behavior and norms that fall not only beyond customary law but beyond qabyalah itself. These contexts, also characteristic of life in rural, tribal Yemen, are locally classified as personal or intimate, foreground autonomous and competitive behavior, and are usually ignored in discussions of tribalism. ${ }^{35}$ Joseph and Joseph (1987), in one of the few published studies of a similar duality in the Moroccan Rif, dub such antithetical behaviors "agonistic." In Yemen, these include money and business transactions, most artistic expression (e.g., music, most genres of dancing and song as opposed to chanted poetry) and personal and intimate relationships (Adra 1982, 1998).

Thus, while hospitality falls under the domain of customary law, as does trespassing on another's land rights or water turns, how any person uses his or her water rations or property is not considered anyone else's business, and irresponsibility in these contexts neither reflects personal or community honor nor can it be legislated by customary law. Although piety is expected of everyone, both lapses in religious observance and extreme conservatism were historically tolerated as personal choices, although there are indications that religious intolerance has increased throughout Yemen with the intrusion of politicized Islam in the past 30 years and especially during the current conflict which warring factions have justified in sectarian terms.

Antithetical contexts reduce the customary restraints on all forms of self-expression, including most dancing and music, love songs, affection between spouses and friends, humor and varieties of play, the behavior of closely related kin (parents and offspring, siblings) to each other, and individual religious observance. Competition in financial and personal affairs allows daily life to proceed and entrepreneurialism to flourish (Varisco and Adra 1984). Poetic, musical and dance events counteract the relentless responsibilities and constraints of qabyalah. Women's dance events are often called nafs, a term that in Yemen is usually glossed as "breath" as in "a breath of fresh air," but which also implies "spirit", "individuality," "competition" and "personal discretion," among other connotations (Wehr

35 I explore this duality at greater length in Adra 1982 and 1998. Explication of this particular duality helps explain the contradictory perceptions of tribes in MENA by external observers, some of whom characterize tribes as essentially cooperative, while others focus on competition between individuals and tribes. Both are correct: tribes in MENA are simultaneously cooperative and competitive. 
1960, 984-985). Women's social gatherings are typically known as tafritah, connoting escape from daily chores. Arguably, these contexts provide release from the stringent requirements of qabyalah.

Within these diverse but clearly bounded areas, the range of acceptable behavior is determined by individual discretion and the dynamics of the particular household. Social disapproval enters the picture primarily when individuals cross the acceptable boundaries between contexts in which self-expression is permitted and accepted and those in which behavior deemed qabyalah is required. Both sets of norms intermingle in daily life, with one or the other prevailing depending on the context. A certain restraint is expected in the presence of people one would like to impress, and issues defined as intimate are not often discussed in contexts defined as public, since etiquette requires they be ignored. However, private property, poetry, dancing, romance within marriage and play are highly valued. They are all considered normal parts of life, but some behaviors are not for overt exhibition. Questionable behavior within and outside of qabyalah, however, is regularly discussed through gossip.

The term qabyalah integrates ideals of tribalism, yet no analogous term represents the domains defined as personal, which extend far beyond Herzfeld's "cultural intimacy" (2015). The diversity of activities locally defined as intimate or personal often involves behavior perceived to be inconsistent with or antithetical to qabyalah, such as folklore that exalts the individual and love songs that glorify handsome heroes and beautiful women. It is perhaps for this reason that such activities do not enjoy the social legitimation or open recognition of qabyalah. Aspects of the culture defined as personal or intimate may or may not be formally acknowledged in local descriptions of their society, and only some of these are considered tribal markers. High-status individuals and older people tend to regard antithetical behavior with ambivalence and avoid overtly competitive behavior or open self-expression in public venues. Marital relations straddle these contextual boundaries: while romance and intimacy are considered deeply personal, the mutual responsibilities of husbands and wives are regulated by custom and the marriage contract. It is significant that the household, the structural foundation of tribal organization, is also the ideal venue for antithetical behavior. Considering the household the most, rather than least, important tribal unit, exposes the potential irony of the household's centrality to both qabyalah's antithesis and qabyalah's norms. From this perspective the household is foundational to the entire cultural duality; not only to qabyalah in tribal praxis. ${ }^{36}$

The Implications of Qabyalah and its Antithesis to Gender Roles in Yemen

As discussed earlier, women are protected by customary law, but their interests must be represented by men in formal contracts and dispute resolution. Legal constraints often serve to disempower women, but a number of safety nets counteract their negative impacts. These include requirements that men financially support the women in their households and support their female kin in disputes with their husbands or in-laws. The component of tribal honor that prohibits tribesmen from assaulting women contrasts with some societies in MENA in which women may be punished for transgressing a family's "honor." Such "honor" killings are rare in Yemen, and it appears that the majority of Yemeni men take the injunction to protect their daughters and sisters seriously (Würth 2005, 304 n. 4). Married women

36 My insight on this point developed through reading Hammoudi's 2017 discussion of bayt as the foundation of both tribal organization and poetry. Hammoudi does not discuss tribal duality or antithetical contexts in tribal life, but I have often wondered at the significance of the term bayt in poetry and its possible connections with the household. 
who feel insulted, or are assaulted, by their husbands or the in-laws with whom they live, have a right to return to their parents' or other kin's home. This move initiates a mediation process between the husband and the woman's kin that may end with reconciliation in return for gifts or in divorce (Adra 2011). (In Yemen's North, divorce is not stigmatized as it is in parts of the South.)

Furthermore, women's participation in the rural economy assures them greater mobility than that enjoyed by their urban sisters. Gender mixing is the rule in villages, and in many villages until the early years of this century women and men danced together all night at weddings and other celebrations. Women inherit and control their own property, and in the Zaydī North, men do not control their wives' property. Although brothers routinely pressure their sisters to cede the management of their inherited land to them, they must ensure their sisters' life-long support in exchange. The majority of women accept this option, but some women refuse it, choosing to manage their own land instead (Adra 2013). From a top-down perspective, women are not legitimized as public personae. Yet women control the household, the foundation of tribal structure; hospitality, one of the most important components of tribal honor; and children, who are very highly valued in this society. The power of women at the grassroots cannot be denied.

Ironically, the duality of norms described above provides women with greater freedom of expression than men. In contrast to Euro-American societies, the primary responsibility for community cooperation and coexistence is assumed by men who serve as tribal icons. This leaves women more room for negotiation within their households regarding the management of their land, economic pursuits, education and mobility. Tribal women are less constrained in their political and social critique and tend to be more outspoken than men, who are restrained by stricter rules of propriety (see Gingrich 1997 for an example.) Women's songs, which are heard by all, can reflect deep personal feelings that would not be considered appropriate in other (public) contexts (cf. Abu Lughod 2016, Joseph 1980). I have begun to explore the possibility that women may symbolically represent qabyalah's diverse antithesis as men represent qabyalah (Adra 1998).

The picture is marred, however, by lack of access to adequate health care and quality education, statistics that place Yemeni women near the bottom of international organizations' gender equality indices. Despite high poverty rates and the negative health consequences of early marriage, rural women in Yemen do not behave like victims. They are unusually assertive, stand tall, walk with long strides and express themselves loudly and with confidence. As Sheila Carapico writes, "Yemeni women may be the most liberated, though not necessarily the most privileged, Arab women" $(1991,15)$.

\section{The Resilience of Qabyalah}

To sum up this discussion, tribes in Yemen are primarily territorial groups, divided into ever-expanding units held together by specific mutual responsibilities. Tribal organization is based on sophisticated and adaptive principles that enable groups of varying size to mobilize quickly and effectively to protect their territory and accomplish tasks that benefit their community. Qabyalah is an all-encompassing Yemeni term that integrates the various components of tribalism: origins, organization, customary law, norms, an egalitarian ethic, patriarchy, and aesthetic tribal icons. Qabyalah coexists with an unnamed set of antithetical norms that encourage competition and self-expression in specific bounded contexts. Women in this patriarchal society find themselves at a legal disadvantage, but they benefit from safety nets, mobility and considerable room for negotiating and bending the rules to accomplish their wishes. 
How have tribal ideology and norms survived the immense social and economic changes of the past 50 years? Will they survive the current conflict? First, it is important to note that norms underpinning qabyalah, such as the importance of social responsibility, flexibility and "situational ethics," reliance on due process and mediation as well as positive valuation of entrepreneurialism and the variety of expressive forms, are pervasive throughout Yemeni society and feed local understandings of fairness and the expected behavior of others. To most Yemenis, this complex of expectation and behavior appears "natural" and understandable.

Economic and social change over the past 50 years has had multiple impacts. New opportunities for tribes to engage in trade and other new professions have propelled cross-status endogamy and the acceptance as equals of formerly disdained status groups. Educational opportunities have expanded for women and men. Many more women now benefit from formal education, and female enrollment in Yemen's universities surpasses that of men. On the other hand, Islamist teachers and curricula have negatively impacted women's agency and voice. Many young tribal women who have completed secondary school now idealize women's seclusion and unquestioning obedience to their husbands as "modern" in contrast to tribal women's mobility and voice. Women's song, poetry and dancing have been curtailed in many villages (Adra 2016).

Massive food imports have undercut local dry farming in highly nutritious grains and seeds, accelerating the erosion of terraces and traditional water conservation methods. These, along with increased cash cropping, which has enriched some communities, have reduced rural women's economic contributions and consequent mobility, because cash cropping is defined as men's work. The traditional work ethic appears to be weaker among the youth, who no longer value agricultural work. Intense bar 'ah continues among some tribes, e.g., the Yāfi', but it has been replaced in other regions with languid performances resembling tribal dances in the Gulf. Older Yemenis are likely to complain that $q a b \bar{a}^{\prime} i l$ are no longer as physically strong as they were a generation ago. They use the term ta'ayyabna (we are dishonored) because they are no longer as hearty and wholesome as they were in the past.

Tribal models of organization that enable groups of varying size to mobilize quickly and effectively to accomplish given tasks, combined with an egalitarian ideology and elected leaders, provide an ideal format for civil society. These institutions provided the model for Local Development Associations initiated by President Al-Hamdī in the 1970s to spur local development efforts. ${ }^{37}$ Customary law continues to maintain security in all areas not ravaged by violent conflict. During the current conflict, tribal leaders have mediated the withdrawal of terrorist groups from cities they had controlled and continue to mediate tribal and intra-tribal conflicts. As Ḥūthī forces marched toward Aden in 2015, several southern tribes organized impressive evacuations from the city. Tribal men and women vote in elections and actively participate in discussions of national and international politics. Most perceive themselves both as Yemeni nationals and as members of tribes. In Dresch's words, "Contexts have changed, not least in that the tribes, and for the first time tribalism, now form part of an explicitly national whole" (1993b, 236). Mohammed al-Zahiri argues that tribes in Yemen continue to perform positive political and social roles that present a check against the misuse of power by so-called modern politicians (2006, 29-30). In 2005, as my friends in al-Ahjur proudly showed me their voting cards and actively debated national politics, they also framed their discussion of recent local changes, including

$37 \quad$ See Carapico 1984 and Swagman 1988 for more information on LDAs. 
the election of younger shaykhs and the revision of laws no longer deemed appropriate, as examples of the dynamic sustainability of qabyalah. They do not perceive tribalism and nationalism as contradictory. Tribe and nation have become two loci of identity, each entailing its own set of responsibilities.

\section{References}

Adra, Najwa. 1982. Qabyalah: The Tribal Concept in the Central Highlands of the Yemen Arab Republic. Ph.D. Dissertation in Anthropology, Temple University.

1998. "Dance and Glance: Visualizing Tribal Identity in Highland Yemen." Visual Anthropology 11:55-102.

2011. "Tribal Mediation in Yemen and Its Implications to Development." AAS Working Papers in Social Anthropology 19:9-10, doi: 10.1553/wpsa19, http://epub.oeaw.ac.at/wpsainhalt?frames=yes.

2013. The Impact of Male Outmigration on Women's Roles in Agriculture in The Yemen Arab Republic. (Report prepared for FAO, Rome, 1983 revised January 2013). Available in pdf at: http://www.najwaadra. net/impact.pdf.

2015. "Don't Throw Out the Baby with Social Evolution. Revisiting 'Tribe' in the Middle East and North Africa" Anthropology News.

2016. "Tribal Mediation and Empowered Women: Potential Contributions of Heritage to National Development in Yemen." International Journal of Islamic Art 5 (2): 301-337.

Al-Dawsari, Nadwa. 2008. "A Story of Tribal Conflict as Told by a Female Tribal Leader." http://yementribalvoices. blogspot.com.

Al-Hamdānī, Abū Muhammad al-Ḥassan b. Ahmad b. Ya 'qūb b. Yūsuf b. Dāwūd (d. circa 970 CE). 1884. Geographie der Arabischen Halbinsel, I. (Edition of Sifat Jazīrat al- 'Arab). D. H. Müller, ed. Leiden: E. J. Brill.

Al-Ṣa 'b al-Jawhī, 'Umar Aḥmad Abū Bakr bin. 2006. Șafahāt min ta'rīkh al-jawhiyyīn. Mukalla: Dār Ḥaḍramawt li al-dirāsāt wa al-nashr.

Al-Zahiri, Mohammed. 2006. "La société yeménite entre politisation de la tribu et marginalization des ONG." In Société civile, associations et pouvoir locale au Yémen, edited by Sarah Ben Nefissa, Maggy Grabundzija and Jean Lambert, 29-30. Șan' $\bar{a}$ ': CEFAS.

Black-Michaud, Jacob. 1975. Cohesive Force: Feud in the Mediterranean and the Middle East. Hoboken: Blackwell.

Brandt, Marieke. 2014. "The Contemporary Structures and Historical Formation of the Khawlān and Jumā' ah Tribes in Șa dah, Northwest Yemen." Anthropology of the Middle East 9 (1): 59-82.

2016. "Heroic history, disruptive genealogy: Al-Hasan al-Hamdānī and the historical formation of the Shākir tribe (Wā' ilah and Dahm) in al-Jawf, Yemen." Medieval Worlds 3:116-45.

2017. Tribes and Politics in Yemen. A History of the Houthi Conflict. London/New York: Hurst/Oxford University Press.

Carapico, Sheila. 1984. The Political Economy of Self-Help: Development Cooperatives in the Yemen Arab Republic. Ph.D. Dissertation, SUNY Binghampton.

1991. "Women and Participation in Yemen." Middle East Report 173: 15.

Caton, Steven. 1987. "Power, Persuasion and Language: A Critique of the Segmentary Model in the Middle East." International Journal of Middle East Studies 19 (1): 77-101.

1990. "Peaks of Yemen I Summon" Poetry as Cultural Practice in a North Yemeni Tribe. Berkeley: University of California Press.

Chatty, Dawn. 1996. Mobile Pastoralists. Development, Planning and Social Change in Oman. New York: Columbia University Press.

Dresch, Paul. 1993a. "A Daily Plebiscite: Nation and State in Yemen." Revue des mondes musulmans et de la Méditerranée 67 (1): 67-77. 
1993b. Tribes, Government and History in Yemen. Oxford: Clarendon Press.

2006. The Rules of Barat. Tribal Documents from Yemen. Șan'ā’: Centre Français d’Archéologie et de Sciences Sociales.

Farès, Bishr. 1932. L'Honneur chez les Arabes avant l'Islam. Paris: Librairie d'Amérique et d'Orient AdrienMaisonneuve.

Fluehr-Lobban, Carolyn, and Richard Lobban. 2002. 'From Social Type to Social Process: Placing 'Tribe' in a Historical Framework." In The Archaeology of Tribal Societies, edited by William A. Parkinson, 13-33. Ann Arbor: International Monographs in Prehistory.

Gingrich, Andre. 1989. "The Guest Meal Among the Munebbih. Some Consideration of Tradition and Change in 'aish wa milh in Northwest Yemen." Peuples Méditerranéens 46: 129-149.

1997. "Inside an Exhausted Community.” In The Ethnography of Moralities, edited by Signe Howell, 152177. London: Routledge.

Goldberg, Jeffrey. 2016. “The Obama Doctrine. The U.S. President Talks Through His Hardest Decisions about America's Role in the World." http://www.theatlantic.com/magazine/archive/2016/04/the-obamadoctrine/471525/.

Hammoudi, Abdallah. 2017. Al-dākhilī wa al-khārijī fil-tanẓīr lil-zāhirra al-qabaliyya. Khuța fì țarīq ta’sīs khiṭāb anthrūpūlüjī mustaqil. (Emic and Etic in Re-theorizing “Tribe": A Step Toward an Anthropological Discourse.) Translated from French to Arabic by Mouldi Lahmar. Omrān 5 (19): 11-56.

Herzfeld, Michael. 2015. "Intangible Delicacies: Production and Embarrassment in International Settings." Ethnologies 36: 41-57.

Ibn Khaldun, 2015. The Muqadimmah: An Introduction to History. Franz Rosenthall, trans., edited by N. J. Dawood. Princeton, NJ: Princeton University Press.

Joseph, Roger and Terri. 1987. The Rose and the Thorn: Semiotic Structures in Morocco. Tucson: University of Arizona.

Joseph, Terri Brint. 1980. "Poetry as a Strategy of Power: The Case of Riffian Berber Women.” Signs 5 (3): $418-434$.

Lancaster, William and Fidelity. 2011. Honour is in Contentment. Life Before Oil in Ras Al-Khaima, UAE and some Neighboring Regions. Berlin: De Gruyter.

Landberg, Le Comte de. 1901. Études sur les dialectes de l'Arabie Méridionale. Leiden: E. J. Brill.

al-Mas 'ūdī, al-Hasan. 1965. Murūj al-Dhahab. Beirut: Al-Jāmi'ah al-Lubnāniyyah.

Meeker, Michael. 1979. Literature and Violence in North Arabia. Cambridge: Cambridge University Press.

Meissner, Jeffrey R. 1986. Tribes at the Core: Legitimacy, Structure and Power in Zaydi Yemen. Ph.D. Dissertation in Anthropology, Columbia University.

Peristiany, J. G., ed. 1965. Honour and Shame. The Values of the Mediterranean Society. London: Weidenfield and Nicolson.

Peters, Emrys. 1967. "Some Structural Aspects of the Feud among the Camel-herding Bedouin of Cyrenaica." Africa 37: 261-282.

Robertson-Smith, William. 1990. Kinship and Marriage in Early Arabia. New Edition. London: Darf Publishing, Ltd.

Rodionov, Mikhail. 2011. "Contemporary Tribal Versions of Local History in Hadiramawt." Proceedings of the Seminar for Arabian Studies, 41:333-337.

Rossi, Ettore. 1948. "Il Diritto Consuetudinario delle Tribu Arabe del Yemen.” Rivista degli Studi Orientale 23 (1): $1-36$.

Salzman, Phillip Carl. 1978. “Does Complementary Opposition Exist?” American Anthropologist 80: 53-70.

Swagman, Charles. 1988. Development and Change in Highland Yemen. University of Utah Press.

Varisco, Daniel Martin. 2017. "Yemen’s Tribal Idiom: An Ethno-Historical Survey of Genealogical Models.” Journal of Semitic Studies 62 (1): 217-241. 
Varisco, Daniel Martin, and Najwa Adra. 1984. "Affluence and the Concept of Tribe in the Central Highlands of the Yemen Arab Republic.” In Affluence and Cultural Survival: 1981 Proceedings of the American Ethnological Society, edited by Richard F. Salisbury and Elisabeth Tooker, 134-149. Washington, DC: The American Ethnological Society.

Wehr, Hans. 1960. A Dictionary of Modern Written Arabic. J. Milton Cowan, ed. Snowball Publishing.

Weir, Shelagh. 2007. A Tribal Order: Politics and Law in the Mountains of Yemen. Austin: University of Texas Press.

Würth, Anna. 2005. "Mobilizing Islam and Custom Against Statutory Reform: Bayt al-ta'a in Yemen." In Le shaykh et le procureur. Systèmes coutumiers et pratiques juridiques au Yémen et en Égypte, edited by Baudouin Dupret and François Burgat, 289-308. Paris: Centre d'études et de documentation économiques, juridiques et sociales. 


\title{
POWER AS PERSUASION IN YEMENI TRIBAL SOCIETY
}

\author{
STEVEN C. CATON
}

Introduction

Who among the contributors to this volume and its readers, who came to Yemen forty or more years ago, could have imagined the country come to the tragic state it is in today? What I write about is a Yemen I knew in the past, and I ask the question, "Is that past still possible in Yemen today?" I hope it is, and I will explain why in this essay's conclusion.

I came to Yemen for the first time in 1978, on a vacation trip from Saudi Arabia, where I was working in the Department of Antiquities and Museums as an assistant to its then director, Dr. 'Abdullah al-Mașrī. The reason for the trip was, one might say, exploratory. I was advised by Professor McGuire (Mac) Gibson from the University of Chicago who was doing research in the kingdom at the time, that if I wanted to study oral tribal poetry in the Arabian Peninsula for my $\mathrm{PhD}$ dissertation in anthropology and linguistics, perhaps I was better off not doing so in Saudi Arabia, as had been my original intent, but in Yemen, where modernization had not yet swept away the country's cultural legacies, and where the tribes still flourished. When I got off the plane and saw the Old City of San ' $\bar{a}$ ' looming darkly against the pale dawn, my heart literally raced, and I decided on the spot that I would heed Mac's advice.

The site of my fieldwork was around $60 \mathrm{~km}$ northeast of the capital, in a tribal region known as Khawlān al-Ṭiyāl, where I was told over and over again the "best poets" lived who still composed in the ancient poetic tradition. I was also told, however, that I would never be able to carry out my research. I assumed this meant I would never obtain official permission from the Yemeni government, but my interlocutors had a more sinister meaning in mind, and ran the side of their two fingers across their throat to signal what the tribes would do to me if I lived among them. To the incredulous question of why the tribes would do such a thing, I was told they were a "violent" people, "lawless" and "irrational." To be sure, this admonition gave me pause, but when I spoke to men who identified themselves as "tribal," they derided this as calumny coming from urban people who were hostile to their ways. They insisted I would be welcome. I eventually did go to Khawlān, though I ended up living in a hijrah village or sanctuary inhabited by sādah (sg. sayyid, descendants of the Prophet Muhammad) and had to venture out from there to attend tribal ceremonial events in which poetry was produced and to meet wellregarded tribal poets whose oeuvre I recorded.

People's lives in the hijrah and its surroundings were suddenly shattered by the abduction of two young tribal women, allegedly by a young sayyid man from the sanctuary, which precipitated a conflict that engulfed the entire region. The father of one of the missing girls, who was also a shaykh of a local tribe, came into the hijrah and raised his jambiyyah (dagger) in the air, while intoning the ritual words "I challenge you!" (meaning that he held them responsible for this heinous crime). He handed the dagger to a third party standing by who was to serve as the initial arbiter of the dispute. Then the shaykh made another pronouncement: if the girls and the boy were not found by sundown, there would be war between the shaykh's tribe and the hijrah. From the start what I call "symbolic violence" was performed 
by the ritual challenge and by the shaykh and his military supporters taking positions on the mountain tops surrounding the sanctuary to signal both the seriousness of the offense to his and his tribe's honor as well as their preparedness to fight to restore that honor if the parties to the abduction were not apprehended. As the deadline for meeting his demand elapsed, despite the efforts of search parties combing the region to find the young man and the two young tribal women, an armed confrontation was "staged" with the sanctuary and its armed supporters that ended after twenty-four hours with a truce. I say staged because it was clear that, although the sanctuary was fired upon and the sanctuary fired back, care was taken not to take the violence too far. After this staged armed confrontation, the mediation process got started in earnest, though it would not have a successful conclusion (if one can even speak of a conclusion to these kinds of conflicts) until six months later, and after several rounds of interlocking violence and mediation that escalated in their scale with each successive round.

It had not been my original intent, of course, to study this event (Caton 1999), which happened unexpectedly while I was conducting fieldwork on tribal poetry, but as I was living in the midst of the controversy that imperiled my neighbors, not to speak of threatening to bring my fieldwork to an end, I could not help but be aware of it, and when I realized that the genres of poetry I was analyzing were constantly referring to the event and its uncertain outcome, I determined to focus my attention on it. My book Yemen Chronicle (Caton 2005) is an account of that event.

In this essay I want to revisit that event and examine it through the lens of a model of power as persuasion that I developed in a couple of publications (discussed below), though I also hope to sharpen that model here by a deeper engagement with various theories of discourse and power (specifically those of Habermas), before going on to ask what salience that model might have both for contemporary Yemeni scholarship as well as for the political future of tribes in Yemen.

\section{Two Idea Types: Power as Persuasion, Power as Coercion}

I published this model for the first time in 1987 in an article entitled "Power, Persuasion, and Language: a critique of the segmentary model in the Middle East" in which I critically examined the anthropological model of tribe going as far back as the classic statements by Evans-Pritchard (1940) and Ernest Gellner (1969). My aim was to reveal in that model what I called a contradiction or tension between a dominant scholarly notion of power as coercive force on the one hand (corresponding to the cultural stereotype that the only thing tribes understand is the use of force) and the far less prevalent notion of power as consensus based on moral suasion, accomplished in large part through communication, especially poetry. After arguing that both these understandings of power have to be kept in view if politics is to be understood in the tribal context, I did a cultural interpretation (following Clifford Geertz 1973) of persuasion; that is, interpreting what the communicative act of persuasion might mean in the subjective view of the actors involved in the dispute mediation.

I realize now, however, that what I was proposing in that 1987 paper might be better served by framing it as a Weberian ideal type of persuasion. This is not the place to go over Weber's fragmentary discussion of what he meant by the ideal type (Weber 1949, 1968); suffice it to say that I mean by it a constellation of traits, derived from empirical investigation, that have some sort of affinity with each other, usually based on logical coherence. Thus, for persuasion, I would argue, the ideal type consists of at least three traits. (1) There are agents who think of themselves as autonomous social actors, however defined in local cultural terms, because, as I wrote at the time, "an actor would only try to persuade someone he could not or should not compel. In other words, actors must believe that they are 
in some sense free to accept or reject political policies and that their decisions matter in the decisionmaking process" (Caton 1987, 96); (2) While there are men of power to be sure, they are ideologically constituted as "first among equals," and they are enjoined to govern by consultation and consensus rather than by coercive will or the use of force. (3) Communication between agents consists of what I called cultural "forms of speaking," especially poetry, though including also genres such as sworn oaths, proverbs, challenges and counter-challenges, and legal discourse such as sworn testimony, legal judgments and so forth. In hindsight, I realize that I left out "forms of writing" that are part and parcel of persuasive processes which Dresch (1989), Weir (2007) and especially Messick (1993) have examined in works that came out after my article was published, and I left out image-media such as videos and social media, which have increasingly become part of the tribal communicative sphere since I did my original fieldwork in 1979-81.

To continue with my argument, this ideal type of power is the dialectical opposite of the one the literature on tribes has tended to elucidate. The latter ideal type is instrumental rather than moral/suasive and focuses on (1) the monopoly of the instruments of violence in the hands of powerful shaykhs and their supporters; (2) the consequent military as well as political-economic means at the disposal of such shaykhs to coerce others, including buying their allegiance; and (3) the use of kinship and marriage relations to create alliances and curry favors. In this type, forms of speaking like poetry are little more than epiphenomena or idle pastimes, and certainly of little or no consequence in the weighty task of governance. They are treated either as minor entertainment or of purely ceremonial significance or, if connected to the art of rule at all, as praise poems to the rulers.

What, then, according to my argument, is the epistemological status of these two ideal types? It would be a mistake, it seems to me, to assume that the moral/suasive type is somehow closer to the subjective view of the actors (Verstehen) and the instrumental/coercive type closer to the investigator's explanation of what is "actually" going on (Erklären). I argue that the instrumental/coercive type is also a subjective/interpretive one, in the sense that tribal actors understand other people's actions in those terms and their understanding of it (Verstehen) is communicated in genres such as poetry.

For example, in the protracted dispute I introduced above, the negotiations dragged on for months because the plaintiff in the case refused to agree to a settlement despite the best-faith efforts of the negotiators working within the legal-moral system to bring the conflict to an end. Thus, suspicions were aroused over his recalcitrance, and an interpretation based on an instrumental and coercive understanding of power as force began to circulate; namely, that the shaykh and the tribe supporting him wanted to derail the negotiations in order to tip the conflict into open warfare, an armed conflict the tribe was confident it could win because of its superior military strength, and with the aim of plundering the sanctuary and gaining political ascendancy in the region. This interpretation spurred a mobilization of a yet larger contingent of regional tribes coming to the defense of the sanctuary in order to stop the opposing tribe from imposing its will by force. In the end, the latter was beaten back, but - and this is important for my argument - the latter went back to negotiations with the hijrah as demanded by their opponents, and the dispute was eventually settled in accordance with tribal law (settled, yes, though not entirely ended as it turned out). Also important to note is that the tribes that mobilized in defense of the sanctuary did so not to coerce their opponent into submission to their desired instrumental aims but to continue with the mediation process, trusting that the outcome would be amenable to all parties concerned. Force, if anything, was used to reconstitute the moral order of persuasion, not to supplant it. 


\section{A Dialectic Between and Within}

In a very real sense, then, force and persuasion are in dialectical tension with each other in the dispute mediation, but to grasp this point more subtly we need to complicate what we mean by force, as being dialectically both a symbolic gesture of violence like a threat and an enactment of armed violence against the other. Consider, for example, one of the prototypical acts of challenge and response in everyday life in Yemen: a man feels that his honor has been impugned by an alleged crime against him (say, the failure to repay a debt). Going up to the man with whom he has this dispute, he withdraws his jambiyyah from its sheath and raises it aloft while uttering the words "I challenge you! (ana d $\bar{a} \bar{l} \mathrm{l} l-a k)$ " Taking out his dagger in turn, the man indexed by this formulaic challenge is honor-bound to respond, "And I am respectful! ( $w$-anā muhtarim)" The two men then hand over their daggers to a third party, usually a male bystander, who is honor-bound to accept them as guarantors of the peace and to act as mediator of the dispute. This exchange of challenge and response and the handing over of weapons to a third party who must act as mediator is a profound ritual, the equivalent of a Durkheimian social fact if there ever was one. The third party, for instance, cannot refuse to act as mediator on the grounds that he is too busy or unqualified (for instance, that he does not know tribal law, because someone else more knowledgeable may be consulted to help adjudicate the dispute). At this point in the proceedings a crowd usually gathers around the plaintiff, the defendant and the mediator to hear the discussion and to offer their own views on who is at fault and who is innocent. Some among them might even provide circumstantial testimony or shed light on the character of the two parties. Eventually, the mediator must pronounce judgment. He will have learned enough from the crowd around him to know what the consensus view is of the guilt and innocence of the litigants (which is usually a matter of degree rather than a simple dichotomy of guilty/not guilty), and he should know enough about tribal law to set the terms of reparations, including fines. Usually that settles the matter and the daggers are returned to their scabbards; but if either of the litigants (and usually it is the plaintiff) feels that his grievances have not been adequately heard or redressed, he has the option of taking the case to the next level in the adjudicative process, a hearing, as it were, in front of a $q \bar{a} d \bar{l}$ or judge. The larger point is that the moral imperative to resolve differences peacefully runs deep in everyday life; the use of actual force (as opposed to threatened force) being a last resort rather than the option of first choice. When the shaykh came into the hijrah to throw out his challenge, the sädah were honor-bound to submit to negotiation and make amends in accordance with tribal law.

But this was not to be a quick or easy process, for a whole host of reasons I discuss elsewhere (Caton 2005). The initial round of mediation failed, and the shaykh led his tribesmen in an attack against the hijrah that left two dead and several wounded among his men. After that, a second round of mediation began, with ever-more powerful regional shaykhs participating in the negotiations, but after several weeks it too failed to lead to a mutually satisfactory conclusion, at which point a very large contingent of armed men on the side of the hijrah attacked the shaykh and his village for not agreeing to a settlement even though this was what tribal law demanded. The shaykh agreed to submit to a third round of mediation, this one presided over by the paramount shaykhs of the Hāshid and Bakīl tribal confederations, who threw all their moral authority as well as their military might behind the successful conclusion of the conflict. What this example makes clear are the successive gradations (specifically, the scaling up) in the dialectics between the symbolic show of force versus its actual performance with the intent to coerce.

To provide a more nuanced understanding of this dialectic, we have to consider forms of speaking as possible forms of force (otherwise we are in an untenable position of claiming that force only entails 
weapons or the threatened use of weapons). Recall in Evans-Pritchard's ethnography of the Nuer (EvansPritchard 1940) the leopard-skin chief, the religious figure who helps adjudicate disputes. He does not have armed supporters to back his verdicts, he is without power in a brute material sense. However, he is not powerless, for if the disputants refuse to accept his verdict, he can curse them. The curse is the religious equivalent of the physical use of arms. The curse is believed to have severe repercussions for those who have been cursed, including grievous physical and mental harm that fall upon those who have been cursed, and thus is not performed lightly. So too an opponent may be cursed in Yemeni tribal poetry, though never gratuitously so, for there has to be a justified provocation for resorting to such a violent form of language. One can shame the opponent by saying that his dignity has been sullied because of the wrong he has committed; to call him a "horse's ass" is to ridicule him and provoke a physical assault, and is therefore considered beyond the pale. Of course, it is possible that that may be the intention behind the humiliation, for it is hard to imagine those who resort to such an extreme form of speaking being naïve about its consequences, but not necessarily so. One does not utter the curse or the vilification out of the blue; one arrives at it, gradually. Here we come to the idea of gradation, enunciated above in the discussion of force, and of scaling up. Exerting moral pressure upon the other entails ratcheting up the criticism, and with each successive round of challenge-and-retort this pressure and counterpressure becomes more heated and nears the tipping point, where shaming spills over into cursing. When the curse is finally performed, it vilifies the other, who now has no choice but to respond in kind, terminating the round of verbal challenges and retorts and initiating the exchange of physical force. Just as there is sometimes a fine line between a symbolic show of material force and the exercise of physical force to do real harm to others, so there is a fine distinction between criticizing someone by calling them to account for their heinous actions in order to get them to mediate and cursing them, thereby casting them out of the moral community and ending any further discussion. But, as I said, one arrives at that point, if one arrives at it at all, gradually, not precipitously.

Now that we have grasped the analytical distinctions between and gradations in a show of force and the exercise of it, between an invocation to mediation and a curse to end it, we can see the dialectic between these ideal types of power unfolding more complexly and subtly in dispute mediations. A show of force (the threat) initiates a round of mediation in which linked poetic performances exhort the litigants to come to terms and ultimately to accept them; but if that fails, a new show of scaledup force (more armed opponents facing off) is performed, precipitating another round of mediation, this one involving more powerful mediators and often more skillful and compelling poets shaming the parties who have done wrong and who continue to refuse to accept a peaceful settlement of their differences. If the parties remain recalcitrant to a peaceful resolution in that mediation process, they might find themselves cursed by the mediators and the show of violence may now tip into the "real thing," or armed confrontation with the aim to maim or kill. One has now reached an extreme in both physical violence and language, and the dialectic seems to have ground to a halt. The moral and political community is in crisis. What will save it, if anything can, are the highest-level shaykhs in the region and the country who throw all their moral authority, and sometimes also their physical power, behind the resolution of the conflict. Some conflicts in the past may have reached that point, but I think not many of them. The conflict between the sanctuary and the tribes did reach that point, though catastrophe was averted in the end. 
Theoretical Interlude on Discourse and Power: Foucault and Habermas

The ideas I put forward in the late 1980s and early 1990s of power being exercised in tribal society through a rhetoric of persuasion and not just the exercise of coercive force provoked little reaction, except perhaps one of mild skepticism (expressed in personal communication rather than in print). Any number of reasons might have been behind this skepticism, not the least being an incredulity that poetry could serve as a vehicle for power (as opposed to, say, legal instruments) which is deep-seated and widely held in our Western political tradition. I was making the argument that poetry could do just that, if one expands one's definition of poetry to include not just a finished text but also a multi-media, oral composition performed in key institutional contexts such as weddings and religious ceremonies. Another problem, as I see it, was that theories of language that incorporated power in their purview and that I relied upon in my analysis were relatively uncommon at the time. There was work on pronominal switching of tu/vous to signal differences of power and status (Brown and Gilman 1960) and the lectures of Austin (1962) on performative utterances, but key theoretical texts on which my thinking depended such as Vološinov (1986) and Bakhtin (1981) were only just being translated and more widely read.

However, a deeper reason for the skepticism toward a notion of power as persuasion may have had to do with Foucault's theory of discourse and power which was widely influential from the 1970s until today. It was incompatible with the concept of power I was developing by deflecting attention away from concrete acts of inter-subjective communication and from intentional, sovereign acts of power to something else entirely, something that it is fair to say we hadn't clearly seen or appreciated before. The following discussion may come across as a bit of a tangent, but I hope it will clarify how I was thinking about discourse and power by comparing it with a very different theory of these same notions that was dominant in anthropology and political theory at the time that I was writing up my research on Yemen.

First, Foucault shifted the meanings of what we generally understand by discourse, and though there is not enough space to go into the details of his arguments, I want to give a cursory summary to illustrate my point. In Archaeology of Knowledge Foucault distinguished between what he called énoncé (enunciation), or concrete acts of communication, which he consigned to the field of linguistics, and what he called discourse; that is, statements derived from a corpus of texts that are much more ill-defined or fluid than concrete speech utterances but that nevertheless form an ensemble or set of connections and are historically crucial in constituting certain objects of knowledge, methods, procedures, and subjects. Less interesting to Foucault were those utterances that could be attributed to specific individuals to whom one might (or might not) attribute specific intentions, or to persons addressed by those individuals and how they might interpret or take up the utterances (Austin 1962), or a situation of utterance (Malinowski 1923) which the utterances index in some fashion or other (Silverstein 1976), and so forth. As Foucault's thinking on discourse developed, it expanded beyond the ensemble of statements to be extracted from written texts to include practices or techniques that these texts talked about and which over time became techniques of power for various institutions in society such as the clinic (Foucault 1975) and the prison (Foucault 1979).

As Foucault's thinking on discourse evolved, so did his thinking on power. It should be apparent from what I said above about his bracketing of the énoncé that the kind of power he had in mind was not exercised intentionally by actors through concrete signifying practices or what he called in one of his lectures (7 January 1976) power's "internal point of view." 
Let us not, therefore, ask why certain people want to dominate, what they seek, what is their overall strategy. Let us ask, instead, how things work at the level of ongoing subjugation, at the level of those continuous and uninterrupted processes which subject our bodies, govern our gestures, dictate our behaviors, etc. ... we should try to grasp subjugation in its material instance as a constitution of subjects. ... I believe that we must attempt to study the myriad of bodies which are constituted as peripheral subjects as a result of the effects of power (Foucault 1980, 97-98; emphasis in the original).

Power in this sense as material practices that subjugate (later usage would be discipline) our bodies, is understood to be diffuse or capillary, constantly circulating, and fragmentary rather than unitary (Foucault 1980), and though its political effects are not necessarily imagined or intended, they are nonetheless palpable and substantial.

The question remains as to the relationship of these two sorts of power to each other: sovereign power on the one hand and disciplinary power (or what eventually came to be called bio-power) on the other. Was sovereign power simply to be replaced by bio-power? It seems not, for Foucault was not claiming that sovereign power was merely an ideology and that somehow "real" power was biopower; rather, he was arguing that disciplinary power operated under the radar of sovereign power and therefore was more difficult to detect if one used sovereign power as one's primary analytical lens. Moreover, according to Foucault, disciplinary/bio-power seems to have gained in importance since the rise of modern society, and therefore has epistemological privilege for students of the latter.

This new type of power, which can no longer be formulated in terms of sovereignty, is, I believe, one of the great inventions of bourgeois society. It has been a fundamental instrument in the constitution of industrial capitalism and of the type of society that is its accompaniment. This non-sovereign power, which lies outside the form of sovereignty, is disciplinary power (Foucault 1980, 105).

Put this way, one could view Weber's analysis of the rise of capitalism in the West as a result of a Protestant ethic that disciplined the mind and body (Weber 2009), an ethical disciplining that then migrated into the economic sphere where it affected the rise of capitalism by creating certain kinds of disciplined economic subjects.

If Foucault's periodization is correct and disciplinary power really is an invention of bourgeois society, then does it make sense to use this notion of power to grasp tribal society? Insofar as the tribes of Yemen have been impacted by modernity (and they certainly have), would it not be reasonable to suppose that techniques of bio-power have found their way into their society, requiring us to go beyond the sovereignty model that so far has dominated their study? And what would such a bio-power study of the tribes look like? Or, if Foucault is incorrect in his periodization and origins of disciplinary power, how might we recognize it in places like Yemen? Brinkley Messick (1993) has arguably provided a Foucaultian analysis of scriptural or textual culture among the literary elite in Yemen, but I am not sure that anyone else has done the same for Yemeni tribal groups, or if it even makes sense to apply a disciplinary lens to our understanding of power in the Yemeni tribal context.

Counterposed to Foucault's model in the 1970s and 1980s was that of Jürgen Habermas, especially as articulated in his work The Structural Transformation of the Public Sphere (1962; first published into English in 1989). It is fascinating to see how diametrically opposed the two are in their thinking about discourse and power. If Foucault argued that disciplinary/bio-power was the invention of the 
bourgeoisie, Habermas argued that the bourgeoisie invented its opposite, so to speak, a democratic public sphere, that is, a society of property-owning, educated individuals that arose in tension with the state (which they saw as hampering their interests) and who engaged in "rational" critical discourse about how the economic and political orders should be run, about the rights and responsibilities of individuals in those orders, and so forth. It was assumed that those individuals who took part in those debates and discussions were more or less "equal," and that they would attempt to persuade each other as to the correctness of their views by a reasoned appeal to fact and truth. These debates and expressions of opinion took place in a "free" and "independent" press, in debating societies, public lectures, salons and so forth, comprising a forum or sphere that was "public" for all to read and, in theory, to participate in (so long as they were property-owning males, of course). Habermas traces the rise of this bourgeois public sphere in the early to mid-nineteenth century and its rapid decline only a couple of decades later, attempting to understand the conditions of possibility for its emergence and its eventual demise. In today's world of "fake news" and "fake facts," with democratically elected leaders spreading disinformation in their wars against their opponents, Habermas' focus on the public sphere and communicative discourse seems more salient than ever before.

What Habermas' training in the Frankfurt School did not prepare him for was a theoretical understanding of communicative action, which was needed in order to grasp how debate operates in the democratic public sphere. For this, he turned (Habermas 1994, 1987), rightly, to pragmatic theories of language; that is, of speaking that is inter-subjective and grounded in concrete contexts of social interaction. His coverage was wide-ranging and deep, including not only Austin but also the pragmatists like Peirce and Dewey. But communicative action in the public sphere, as Habermas saw it, also required a theory of language that was self-referential - that could take speaking itself as an object of description and ultimately of criticism - for that is what debate is all about, speaking to the communicative expression of divergent points of view. George Herbert Mead was helpful here, but so too - and perhaps especially so - would have been Bakhtin (1981) and his idea of dialogicality (and his comments on authoritarian discourse), which, as far as I know, Habermas did not consult. Dialogicality refers to the fact that in every utterance is already embedded a "reply" to a previous said of discourse, not to mention an anticipation of an "answer" to one's own utterance, thus rendering speaking debate-like at its very core.

Habermas' ideas about the public sphere based on critical communicative action, if also necessarily untethered from the particular history of its emergence in the rise of the European bourgeoisie, would have been extremely useful to my analysis of Yemeni tribal poetry that is audio-taped, sold in audiocassette stores throughout the country and then circulated in the national public sphere (Caton 1990). Regrettably, I did not start thinking about Habermas' theory of communicative action and the public sphere in relation to my own research until after I had published my book. How were his ideas relevant? After the 1962 Yemeni revolution, tribes were eager to participate in an emergent national public sphere, one that was not reliant on print and the newspaper but on the cassette tape and cassette tape player which became a widely accessible technology in the 1970s. Through this media they could express their views on national events and policies and try to shape them. Of the three poetic genres that constitute what I call a system of tribal genres, it is the qașidah that was audio-taped and then circulated, and no doubt for the reason not only of its cultural symbolic value or artistic prestige in the Arabic literary tradition but also because its composition is not crucially tied to a performative situation, as is the case for the bālah and the zammil. It is the text (nașs), the product of an individual compositional process, that is esthetically prized in the qașidah, and it is this text that can be most easily extracted from a context of creation, written down or taped and then passed around or listened to on audio-cassette players by 
audiences everywhere, tribal and non-tribal. For example, a well-regarded poet representing the views of his tribe would compose a qașidah poem weighing the pros and cons on a particular issue and then make an argument as to why his group came down on one side or another of the debate. This poem would then be set to music by a professional tribal singer (mulahhin) who would perform it in front of a tape recorder, and the tape would then be sold in local markets all around the country. The tape might then be heard by another poet, representing a different tribe, who might feel inspired to respond with a poem of his own, the two poems linked as a "challenge" and a "response." The second poem might then be sung by the same singer and the two appear on the same cassette tape, again to be sold in various outlets. And so it might continue, with a "chain" of such poems responding to each other and constituting a lively debate between presumably equal actors trying to persuade each other about the rightness of their positions. In this fashion, tribes from across Yemen could hear what each was saying about particularly urgent topics (the policy of rapprochement between the two Yemens in the 1980s, the prohibitive rise in "bride price," the scourge of revenge killing or tha' $r$, and so on). Not just tribesmen but also non-tribesmen listened to these debates in order to get a sense of what the tribal public sphere was debating. Miller (2007) expanded this analysis of poetry's production for and in the Yemeni oral/ aural public sphere by showing how diasporic poets participated in and widened the borders of the public sphere beyond Yemen in the 1990s and later.

\section{Power as Persuasion: Its Past and Future on the Arabian Peninsula}

Two questions about the notion of power I put forward for Arabian tribes interested me, and both might be said to be temporal: the first was how far back the existence of this power extended into Arabia's past; the second was whether it still existed in the contemporary period .

I found the answer to the first question in research by the linguist Samuel Liebhaber on Mahrī, one of six modern South Arabian languages still spoken in the Arabian Peninsula today. His focus is on the qașidah as it is composed by Mahra (or Mehri) speakers in the Mahra Province of southeastern Yemen and in the Dhofar Province of southwestern Oman.

In his article "Rhetoric, Rite of Passage and the Multilingual Poetics of Arabia: A thematic reading of the Mahrī Tribal Ode" (2013) Liebhaber argues for a "common core" to be found in Mahrī poetry, other contemporary vernacular poetry such as Nabațī written in Saudi Arabia and the Gulf, and the ancient pre-Islamic qașìdah. By "common core" he means "a common conception of human society that is structured around the conflicting obligations of feuding and feud-mediation" $(2013,118)$. He grounds part of his analysis of this common core in Susan Stetkevych's application of the Van Gannep paradigm of rites of passage to pre-Islamic Arabia (Stetkevych 1993), with feud beginning as a breach of the moral order that requires "mature males" to repair (i.e., males who have been properly initiated into the moral order). Indeed, my analysis of the bālah performance at the wedding samrah bears this out, for although it is subjectively understood as a "game" to divert or entertain the groom, I argued that it is also a profound allegory about the dangers of heedless youths pushing symbolic violence too far and plunging it into feud and how they require mature males to reign them in (Caton 1990). Explained in this way, one can see how this performance genre is a kind of rite of passage for youths who must learn to submit to the tribal order.

The other underpinning of Liebhaber's analysis is more directly connected to my own work, for he cites both my 1987 article and my 1990 ethnography of poetry as the basis for understanding the language of Arabian poetics as mediation: 
I will draw from Steven Caton's ethnographic analysis of Yemeni tribal poetry from Khawlān al-Tiyāl. Arguing against a strictly coercive definition of power in tribal societies, Caton has demonstrated that the "rhetoric of persuasion" embodied in the poetic practices of northern Yemeni tribesman is more relevant to the management of social welfare than coercion (Liebhaber 2013, 119).

What Liebhaber then goes on to show, through an extended analysis of two Mahrī poems and a comparison with some pre-Islamic odes, is that a notion of social maturity tied to honor on the one hand and collaboration to resolve differences peacefully on the other, based on persuasion and consensus rather than force, are at the heart of the "common core." In sum, he suggests that power as persuasion is deeply embedded in the tribal moral order of Arabia, going back centuries, even cutting across different languages within the Arabian Peninsula. There is, then, a historical depth to the kind of power as persuasion I had encountered in contemporary tribal Yemen about which I had no inkling before Liebhaber's analysis.

But there is every reason to question whether such a concept of power has any salience in contemporary tribal Yemen, given the changes the country has undergone since the 1980s. For one thing, both the position and structure of the shaykh's power seem to have undergone a profound shift since that time, away from a status of "first among equals" to one of greater power based on ties to the central state on which the tribes depend for essential goods and services crucial to their economic development. As has been argued above, persuasion, if it is to be real, presupposes actors who are more or less equal and not in a relationship of domination and subordination to one another. And did the strategy of the Șālih regime of sewing discord among the tribes as a way of weakening them and thereby of mitigating their opposition to its rule exert such stresses on the mediation system that it could no longer handle the disputes (both in volume and intractability) coming its way? And what of the concomitant rise in sales of armaments to Yemen, much of which ended up in the hands of the tribes: did the moral imperative to resolve disputes by mediation and consensus give way to the instrumental use of force to coerce one or more parties to do the bidding of the other? In such circumstances the odds do not look good for a power based on persuasion rather than coercion or force.

It was heartening, therefore, to encounter it in the revolutionary rhetoric of the 2013 Yemen "Change Revolution." One of the most iconic moments of that revolution was when thousands of tribesmen joined the protesters in Change Square by laying down their weapons at the entrance to Șan ' $\bar{a}$ ' University. It was a symbolic gesture of their commitment to non-violent protest. They later composed zāmil and other poetry while marching in the streets of Șan ' $\bar{a}$ ', as described in an article, "Poetry of Protest: Tribes in Yemen's 'Change Revolution"” (Caton, El-Eryani and Aryani, 2014). Many Yemenis were amazed to see tribesmen laying down their arms, and yet it is in keeping with the rhetoric of persuasion that I have outlined.

It is Ross Porter in his yet unpublished book manuscript, 'Being Change' in Change Square: An ethnography of revolutionary life in Yemen (2019, forthcoming), who picks up the model of power as persuasion and develops it subtly and insightfully for the Yemeni Arab Spring.

I have found Caton's work on tribal poetry to be particularly useful for developing an explanation for the most celebrated of revolutionary moments in 2011: when several large tribal delegations came into the Square announcing a rejection of their former way of life. Where dialectics and a mutual respect for autonomy lies at the heart of successful conflict 
mediation, the emergence of a political system (especially post-unification) committed to increasingly coercive tactics resulted in a perpetual state of war... The ideals of tribalism became increasingly difficult to uphold in the face of what was seen as oppression (thulm) (Porter 2018, 37).

In other words, the Șālih regime's tendency of increasing authoritarianism, in which coercion rather than persuasion was the tactic of rule, became intolerable, and the tribes in the Change Revolution reverted to their understanding of power as persuasion to assert another, more peaceful way to imagine the political order.

Tragically, the aftermath of the Change Revolution has plunged Yemen into a bitter, protracted and bloody civil war between the Hūthīs and their Iranian supporters on one side and the Saudi/UAE coalition backing President-elect Hādī on the other. There is no need here to go into the details of this conflict which have been fully analyzed elsewhere (Brandt 2017). What this conflict has led us back to is a notion of power in which force predominates over persuasion, even begging the question of whether persuasion still exists. I want to remind us that there was another, even bloodier and more protracted civil war in Yemen from 1962-1970, and yet the model of power as persuasion survived. One might hope the same will be true now. It is clear after several years of inconclusive fighting that neither side can win by use of force alone, and at the time of writing this essay there seem to be fitful efforts at a truce in order to begin the long, difficult process of mediation and negotiation. Without such a process one cannot see how a lasting peace can be achieved.

Epilogue

Let me conclude, then, with a hopeful anecdote. Speaking recently to a political scientist who works for the International Crisis Group, one Yemeni shaykh from Khawlān said to her that the shaykhs had decided that the fighting in the civil war would not spread to their region. Disputes would have to be resolved without arms or the coercive use of force. Perhaps the political model I have sketched in this paper is not defunct after all.

\section{References}

Austin, John. 1962. How To Do Things With Words. New York: Oxford University Press.

Bakhtin, M. M. 1982. The Dialogic Imagination: Four Essays. Translated by Caryl Emerson and Michael Holquist. Austin: University of Texas Press.

Brandt, Marieke. 2017. Tribes and Politics in Yemen: A History of the Houthi Conflict. London/New York: Hurst/ Oxford University Press.

Brown, Roger; Gilman, Albert. 1960. "The Pronouns of Power and Solidarity." In Style in Language, edited by Thomas A. Sebeok, 253-276. Cambridge, MA: MIT Press.

Caton, Steven C. 1987. "Power, Persuasion, and Language: A Critique of the Segmentary Model in the Middle East." International Journal of Middle East Studies 19:77-102. 1990. Peaks of Yemen I Summon: Poetry as Cultural Practice in a North Yemeni Tribe. Berkeley: University of California Press.

1999. “'Anger be now thy song': The Anthropology of an Event.” Occasional Paper 5, School of Social Science, Institute for Advanced Study, Princeton, NJ. 
2005. Yemen Chronicle: An Anthropology of War and Mediation. New York: Hill and Wang.

Caton, Steven C.; Al-Eryani, Hazim; Aryani, Rayman. 2014. "Poetry of Protest: Tribes in Yemen's 'Change Revolution'." In The Political Aesthetics of Global Protest: the Arab Spring and Beyond, edited by Prina Werbner, Martin Webb, and Kathryn Spellman-Poots, 121-144. Edinburgh: Edinburgh University Press.

Dresch, Paul. 1989. Tribes, Government and History in Yemen. Oxford: Clarendon Press.

Evans-Pritchard, E. E. 1940. The Nuer. New York and Oxford: Oxford University Press.

Foucault, Michel. 1972. The Archaeology of Knowledge. New York: Pantheon Books.

1975. The Birth of the Clinic: An Archaeology of Medical Perception. New York: Vintage Books.

1979. Discipline \& Punish: The Birth of the Prison. New York: Vintage Books.

1980. Power/Knowledge, edited by Colin Gordon. New York: Pantheon Books.

Geertz, Clifford. 1973. The Interpretation of Cultures. New York: Basic Books.

Gellner, Ernest. 1969. Saints of the Atlas. Chicago: University of Chicago Press.

Habermas, Jürgen. 1989. The Structural Transformation of the Public Sphere: An Inquiry into a Category of Bourgeois Society. Cambridge, MA: MIT Press.

1984. The Theory of Communicative Action, Volume One: Reason and the Rationalization of Society. Boston: Beacon Press.

The Theory of Communicative Action, Volume Two: Lifeworld and System: A Critique of Functionalist Reason. Boston: Beacon Press.

Liebhaber, Samuel. 2013. "Rhetoric, Rite of Passage and the Multilingual Poetics of Arabia: A Thematic Reading of the Mahri Tribal Ode." Middle Eastern Literatures 16 (2): 118-146.

Malinowski, Bronislaw. 1923. "The Problem of Meaning in Primitive Languages." In The Meaning of Meaning, edited by C. K. Ogdon and I. A. Richards, 296-336. New York: Harcourt, Brace and World.

Messick, Brinkley. 1993. The Calligraphic State: Textual Domination and History in a Muslim Society. Berkeley, CA: University of California Press.

Miller, Flagg. 2007. The Moral Resonance of Arab Media: Audiocassette Poetry and Culture in Yemen. Cambridge, MA.: Harvard University Press.

Porter, Ross. 2018. “'Being Change'in Change Square: An ethnography of Revolutionary Life in Yemen.” Unpublished Ms.

Silverstein, Michael. 1976. "Shifters, Linguistic Categories, and Cultural Description.” In Meaning in Anthropology, edited by Keith H. Basso and Henry A. Selby, 11-55. Albuquerque, N.M.: University of New Mexico Press.

Stetkevych, Suzanne. 1993. The Mute Immortals Speak: Pre-Islamic Poetry and the Poetics of Ritual. Ithaca: Cornell University Press.

Vološinov, V. N. 1986. Marxism and the Philosophy of Language. Cambridge, MA: Harvard University Press.

Weber, Max. 1949 “'Objectivity' in Social Science and Social Policy.” In The Methodology of the Social Sciences, edited by Edward A. Shills and Henry A. Finch, 49-112. New York: Free Press.

1968 Chapter 1, "Basic Sociological Terms," In Economy and Society, Vol. 1, edited by Guenther Roth and Claus Wittich. New York: Bedminster Press.

2009. The Protestant Ethic and the Spirit of Capitalism. New York and London: W. W. Norton \& Co.

Weir, Shelagh. 2007. A Tribal Order: Politics and Law in the Mountains of Yemen. Austin: University of Texas Press. 


\title{
SOME PRINCIPLES AND CONTINUITIES OF TRIBAL LAW
}

\author{
PAUL DRESCH
}

Yemen is unusual in having a long written record of a type of law that its adherents and practitioners, as well as hostile critics, distinguish from sharī ah discourse. It is not unique in having texts on "customary" rules, of course. While there is argument to be had over how much of Indonesian adat was written and how law-like it was until the Dutch set about it, there is no denying the record of, say, Maghrebi or Daghestani non-Islamic law. (Claims that the Maghrebi version was wholly invented by the French, we should note, withstand little scrutiny). Certain forms of Yemeni tribal law are distinctive, however, showing principles of sociality that are not conspicuous elsewhere, and so is its longevity. What I wish to examine is a tradition, or set of traditions, that is far from changeless but that exhibits specific principles consistently for at least seven centuries, down to our own time. ${ }^{1}$

The present volume focuses on present-day concerns. In doing that, it is always sensible to assess what is new and what is not. Modern political language has a genius for disguising its own longterm roots, which include a rather Hobbesian view of state authority, and for claiming that practices disliked by the world's current powers are "traditional," when in fact they are responses to modern politics. But I am not aiming here for an antiquarian corrective. The Yemeni material on law is of interest in itself, and the lessons it has to teach run deeper than current affairs. While its study suggests seeking "the solace of the past in the unspeakable present" (Mundy 2013), the principles at issue are themselves timeless.

At the turn of 1937-38, while based in San' $\bar{a}^{\prime}$, Ettore Rossi acquired four manuscripts, which he describes in Rivista degli Studi Orientali as follows.

1) Copy of a Kitāb al-sinnah (according to the local pronunciation) wa-l-șà 'ibah wa-l- 'urf $a l-j \bar{a} r \bar{\imath}$ attributed to the naqūb 'Abd al-Rabb Ibn Ḥātim Șayyāț. There are twenty-seven pages copied for me in quasi-dialect Arabic from a manuscript dated 1059 AH [AD 1649]

$\cdots$

I have discussed recent tribal law in publications over several decades now. Constraints of space mean I must take much of this as read. More regrettably still, I must leave out references to authors such as Muhammad al-Sudumī whose work deserves notice. 
2) A miscellaneous MS, not dated, probably from the 12th century $\mathrm{AH}$, containing ... eleven folios of an unheaded treatise, whose title cannot be established, the work of $q \bar{a} d \bar{\imath}$ Aḥmad 'Alī bin Zinbā' ... At folio 10 there are reported some passages from a Kitāb alman' of qāộ̀ al-Ḥusayn ibn 'Umrān ibn al-Fāḍil al-Yāmī.

3) A MS of 49 folios divided in two parts: the first, unheaded, is titled Kitāb al-tabyin fi l-man' and perhaps is the work of one Yahyā al-Qaḥtānī from the region of al-Bayāḍ [38 folios]; the second, incomplete, is entitled Talqīh al-hukkām.

4) A Kitāb al-aslāf $w a-l-a$ ' $r \bar{a} f w a-l-t \bar{a} g h \bar{u} t$ by an unspecified author, copied from an original in the archive of a tribal chief; in all, 37 folios in horrible script, stuffed full of errors ....

(Rossi 1948, 17-18)

Rossi knew that he had made an important find, and he quotes from Kitāb al-tabyin at length, reproducing its list of ten major topics: the refugee or protégé; the travelling companion; the ally; the person under safeguard; the namesake; the person connected by brotherhood; the guest; the servant; the affine or in-law; and the inviolability of territory. Unfortunately he did nothing more with these texts before his death in 1955. But he did provide photostats to Bob Serjeant after the latter returned from Hadiramawt.

By then Serjeant had found in Tarīm a much fuller, older and more elaborate text, entitled Kitāb al$\bar{a} d \bar{b}$ b wa-l-lawāzim fì hukm al-man', which he describes, albeit briefly, in the Bulletin of SOAS (Serjeant 1950, 589-91) and which he dates to about AD 1320. For decades, with this and Rossi's material in mind, he referred to a "tribal law corpus" he was editing (see Serjeant 1991). Unfortunately nothing came of it before he died in 1993, and I am now trying to edit all this material before the curse that stopped Rossi and Serjeant dead catches up with me. It has so far been slow work. Locating Rossi's manuscripts in Rome proved oddly difficult, and Kitāb al-tabyin, the text he quotes from most in his article, is now missing; fortunately there exists a transcript of Kitäb al-tabyin in Serjeant's hand, but most of Serjeant's material, including the photostats of Rossi's texts and the original of Kitāb al-ādāb, is missing from his archive in Edinburgh. ${ }^{2}$ If some department of the Vatican is not behind this, or some remnant of the Knights Templar, it can only be the Order of the Illuminati.

A transcript that Serjeant made of Kitāb al-ādāb runs to 146 pages. The original comprised 88 folios. There are missing margins and missing pages (the photocopy that he gave me is itself very faint in places), but most of it is there, and at the start is substantially the same list of ten major topics as in Rossi's Kitäb al-tabyinn. ${ }^{3}$ Indeed these form the headings of well-organized chapters. The list occurs

2 Thanks are owed to Giovanni Canova for locating three of Rossi's texts at l'Istituto per l'oriente in Rome when others there had forgotten they existed. I am also grateful to several people (most recently Marilyn Booth) who, over the years, have asked for me about the Edinburgh archives.

3 To be exact, Kitā $b$ al-ādāb lists the ten $u s ̦ \bar{u} l$ as the protégé, the travelling companion, the ally, the person under safeguard, the namesake, the guest, the hired man (al-ajīr, where Kitāb al-tabyīn has mutakhaddim), greeting (saläm), the affine or in-law, and truce or peace (sulh). In fact, a section on the inviolability of territory comes between that on greetings and that on in-laws (Serjeant n.d., 76-7). 
in a much rougher, muddled form in the second of Rossi's finds, the Bin Zinbā' text. ${ }^{4}$ Probably Bin Zinbā', which is less well written, derives largely from Kitāb al-tabyīn, and both of them plainly derive in the end if not from Kitāb al-āa $\bar{a} b$ then from texts very like it. All three are in the nature of treatises or summaries, as is Kitāb al-sinnah, a rather crudely composed text (not related directly to any of the above) that dates to the mid-seventeenth century and comes from Khawlān al-Ṭiyāl (Dresch 2017).

Other genres at other dates are a help in reading what Rossi and Serjeant found. For example, eighteenth-century "pacts" ( qawä id) from Jabal Baraț (Dresch 2006) contain terms and ideas that occur in early texts, and certain of the terms were familiar to older men at Barat from disputes in their own youth. Parallels and clues to the pacts are meanwhile found in hijrah documents (1070/1660 onwards) from Barat that Qadi Ismā' îl al-Akwa' published (al-Akwa' 1993). Fragments of the qawā 'id, and indeed of Kitäb al-tabyin, have shown up in notes I have seen, and even conversations I have had (sometimes with men who could not read), in several places, and how such fragments may be transmitted I have no idea. They surfaced sometimes in discussions of contemporary disputes in roughly the period 1977-2007, and much that was said and done in such disputes evokes echoes of much earlier reports and texts.

I do not mean by this that nothing changes. Nor do I mean only that particular terms drop out of use and become unintelligible. In the earliest texts, for example, certain wrongs are recompensed twofold (muthannā). In the seventeenth-century Kitāb al-sinnah, as in Qadi Ismā'îl's texts, one also finds recompense fourfold (marb $\left.\bar{u}^{\prime}\right)$, which does not show up in earlier material, and in the Barat qawā'id (mid-eighteenth century) certain wrongs, such as placing a jidhn against a fellow-Muhammadī in Dhū Muhammad's market, are paid for eleven-fold (muhaddash, sic). ${ }^{5}$ Despite the danger of circularity, one is inclined to place texts in sequence by the presence or absence of fourfold penalties and to treat the image of eleven-fold payment as recent. ${ }^{6}$ I doubt very much that the changes relate to monetary inflation. Although Kitäb al-sinnah carefully specifies which kind of buqshah (a small brass coin) is meant for certain payments (Dresch 2017, 12-13), several texts, when discussing blood money, reproduce lists verbatim of how many sheep or bulls are equivalent to how many camels, and how many silver or gold coins equate to each, although the prices of livestock and the value of silver in terms of gold varied over time. More likely the addition of fourfold and eleven-fold penalties represents an "internal" development, stressing certain wrongs rhetorically. As we shall see, the principles that determine when multiple recompense is due at all, and whom it goes to, remain very much the same.

4 This is the text that Abū Ghānim $(1985,363-84)$ reproduces as an unsourced photocopy. He adds to the text a note, for which I see no warrant, that it is known as $q \bar{a}$ 'idat al-sab 'inn.

$5 \quad$ For the jidhn, see Dresch 1987, 2012, 169. The main Barat text here dates to 1211/1796. It derives from an agreement among Dhū Muhammad in 1177/1763, and behind that in turn lay a market guaranty, demanding payment fourfold. Pace Abū Ghānim $(1985,385)$, Dhū Husayn have no part in it. Because Yemen is inaccessible at present, and the book therefore hard to find, I have placed Dresch 2006 on Academia.edu. For a much broader range of material, see Shelagh Weir's archive (Weir 1996, 2007).

6 The absence of fourfold payments in Kitāb al-ādāb and Kitāb al-tabyīn is surprising when one remembers how widespread the formula is elsewhere - Jordan (Jaussen 1908), the desert of Egypt (Murray 1935), the Old Testament and classical Roman law. Another absence is a standard amount for minor "shame" or 'ayb, which in recent times has been 88 thalers among the central Ḥāshid tribes and 110 thalers in Bakīl. 
The nature and place of formalized "custom," set out in texts, require noting. Obviously, first, these are partial laws. At no date do they claim to address everything, and we can be fairly sure (for recent centuries we can be entirely sure) that other topics, such as inheritance, were addressed in terms that attach to sharí 'ah discourse; other topics again, such as grazing and runoff, which may in practice have been distant from learned intervention, were equally distant from the concerns of the Rossi and Serjeant material or the Barat pacts. ${ }^{7}$ Obviously, also, learned persons, such as Zaydī imams, often condemned tribal practice as țaghtut. All too many authors fail to think further. In most literature on most parts of the Middle East, indeed, work on the relation between "Islamic law" and "customary law" is weak, and much of it is pointless, not least because authors fail to see that the usual position in shari 'ah discourse is that whatever is not contrary to shari 'ah principles is available for the shari 'ah judge to use, and "Islamic law" (the practice of judgement through sharī'ah) thus encompasses much custom. Still, customary law may be distinct from $\operatorname{sharī'}^{\prime} a h$ on several grounds.

Early texts say explicitly that in such-and-such circumstance, he of the shar' (a person following law that attaches to sharī'ah discourse) does this, he of the man '(the person following what I think of as tribal law) does that (Dresch 2012, 159, 160). For example, in the case of someone who in error kills his own guest,

Among those of the shar ' his blood-money goes to the [victim's] kin. If it is deliberate, [the killer] is killed in return, With he of the man 'he owes the wound-price if [the offense] is in error, and a penalty like the wound-price; as for if he kills his guest deliberately, among those of the man 'there is no absolution for him among the Arabs ...(Serjeant n.d., 68)

Those of the man ' are those of tribal standing. Their law, although it is not sharī'ah, is not seen as unIslamic. In fact, Kitā b al-ādāb's opening sections argue, in sophisticated terms, with detailed hadìthcitation, that law of this kind ( $h u k m$ al-man ) is that part of Arab law from before Islam that the Prophet of God approved and is therefore right for Muslims of a certain kind to follow. ${ }^{8}$ But a great many topics default to other domains of argument. The law discussed in the texts at hand concerns only specific types of relation among specific types of person.

The same is true, although the relations at issue are different, of the non-sharī'ah Maghrebi law made famous by Hanoteau and Letourneux, documented in datable form further west by Montagne, and recently examined by Judith Scheele (2014). Such texts in northern Algeria have little to say even about the management of pasture (almost nothing about compensation tariffs between sets of people), but a great deal to say about disorderly conduct within the village. Scheele shows how they carve out from a world of movement and migration a set of bounded identities that center on a makhzan or common treasury. Delicts result in a fine that goes to a village council. In Yemeni material, by contrast, it is

$7 \quad$ Kitāb al-ādāb mentions only obligations that arise from herding one's flocks together; the Barat qawā id mention only that one needs five witnesses a side if a border is disputed. On the other hand, Kitāb al-ādāb does include sections on, for instance, inheritance and trusteeship (wișāyah), although there seems nothing self-consciously distinct from sharì $a h$.

8 This text, unlike others, is replete in its opening parts with citation and with literary echoes. The marginal notes, often hard to read, suggest Serjeant spent considerable effort pursuing these. The striking thing about the text itself, however, is that an educated person thought non-sharī'ah law worth serious attention, whereas in recent times, as Rossi makes clear (1948), it was not. Are there parallels elsewhere in the Islamic world? 
nearly all recompense to persons, and the word "fine" is usually out of place. As Frank Stewart pointed out some years ago (Stewart 2000, 890), Maghrebi law of a non-Islamic sort is to do with community, Mashreqi law is to do with transaction. What, then, is the basis of transaction?

A number of early texts from Yemen use the phrase hukm al-man', which Ibn al-Mujāwir records circa AD 1200. As Rossi notes, the term man ' (or man 'ah) already appears in al-Hamdānī (soon after AD 900) with what looks to be the relevant sense, which is not "forbidding" or "prohibiting," but "protection" or "defense"; it works like French, in fact (défendre and se défendre, as well as défense de), and when the Șifah praises tribesmen of Barat as anjad hamdān wa-humät ul- 'awrah wa-mana 'at $u l-j \bar{a} r$, it plainly means "defenders of the protected person" (Rossi 1948, 9). ${ }^{9}$ In law texts the word is sometimes used in a general way, such as when the only people who can swear as witnesses are specified as those who "act on" or "value" the man "by keeping their word and rejecting evil, but usually it attaches to specific persons and signifies a capacity (both a right and an obligation) to defend others. ${ }^{10}$ Tribesmen have man: Hereditary servitors, for example, do not. The law primarily governs relations among persons of tribal standing, and where others are concerned, it is with reference to such persons. ${ }^{11}$

Some of the relations are symmetrical, so the duties of protection that I owe to my in-laws or my sworn ally are the same duties that they owe to me. Others are asymmetrical. If I, as a tribesman, am protecting a non-tribal servitor (a market-person, let us say) and then wrong him by wounding him or taking his goods, I owe him the usual recompense twofold; if he wrongs me, by contrast, he owes me just the usual recompense. But protégés (jīrān, pl. jār) can also be morally my equals. The cases that most interest me as an anthropologist, and that I think are distinctive, are those where the roles of protector (mujawwir) and protégé (jār) are contextual and can be reversed, such that, in theory, I can protect you in my space today - as my guest, for example - and you can protect me in your space tomorrow. ${ }^{12}$ I would owe you twofold for a wrong in the first case; you owe me twofold in the latter, and texts are explicit that this is because of "protection right" (jiyār or jiwār). It is mutual recognition of our capacity to protect that makes us tribesmen. Each of us recognizes, also, that if some third party wrongs a protégé then they owe not only compensation to the protégé but also amends to the protector.

What makes us members of specific tribes is that specific sets of people are implicated in our exercise of protection, and we in theirs. "The neighbor / protégé (jār) of one of them is the neighbor / protégé of them all," as Bin Zinbā' says (Abū Ghānim 1985, 365). Or, "a man gives escort by his tribe, from them

$9 \quad$ Rossi also provides a citation from al-Mas 'ūdī. Dozy gives an example, and Lane's supplement mentions it. Obviously the meanings of "forbidding (to others)" and "protecting (from others)" overlap, but the early Yemeni meaning seems not to be all that widespread. The term is very prominent in Kitā b al-ādāb and Kitāb al-tabȳin but not in Bin Zinbā', although the last appears to draw heavily on Kitāb al-tabyīn.

10 An interesting use occurs, midway between generality and a personal attribute, in Kitāb al-tabyīn (Rossi n.d, 22) when passing a traveler on to another escort: in yusallim-hu ilā man 'ah mithla-hu lam yalzam-hu shay fí-mā jarā 'alay-hi.

11 This is not (pace Weir 2007, 156) "exoticizing" tribal law. The status of guest, for instance, may be conferred by an invitation from a woman, an immature youth, a dependent protégé or even a servitor or slave, but the duty of protection devolves on an adult male of tribal standing. Among those excluded from giving oaths in questions of blood debt are not only Jews and Christians but also the coward and the merchant (Rossi n.d., 73).

12 Pitt-Rivers (1977) attaches this idea of alternating roles to "the law of hospitality." His ideas on "women and sanctuary" are also relevant. Martha Mundy $(2013,5)$ relates how her own work in Yemen (1995) was informed by the idea of the state "vouchsafing" the "internal governing" of households, a pattern which recurs in many traditions, as in Western Europe. The question then becomes how such spaces relate to each other, which is where we encounter tribalism as distinct from other forms of sociality where domestic space is recognized. 
and on them" (min-hum 'alay-him), meaning he is answerable for wrongs by them and against them that concern an escorted traveler, as they are with respect to him (ibid., 367) "And likewise the protégé, the in-law, the namesake ..." and so on through the list. But this is a radically decentered system, with no one person or group in charge. Enforcement of the rules is thus addressed in a language not of power and obedience but of reputation and loss of standing.

If a member of my tribe robs or injures my protégé, he owes twofold (in later material often more than that), as I would myself - unless, that is, the offender can swear he did not know the person was under my protection. In that case, he owes just the usual recompense. But if, in either case, members of my tribe refuse to make reparation, they have committed shame ( $\left.i^{\prime} t \bar{a} b \bar{u}\right)$. In fact they are dughmān (sg. adgham, presumably meaning "blackened"), as they would be if they deliberately, knowing who he was, killed my protégé, or as I would be if I did so, and adgham meant in effect "outlaw," someone with no right to give or take protection (Dresch 2014, 117). The only absolution (naqā) for someone who deliberately kills a protégé is that he kill himself. Failing that, his own group must kill him or hand him over to the dead man's kin, and if they do not, then they themselves are guilty of shame, and on its goes. If this all sounds too dramatic to be plausible, we should nonetheless note the logic. Protection is what, following Jeremy Waldron on American law, I have elsewhere called an "archetype" (Dresch 2012 , 156), something on which other laws depend. We should also note that plausibility is no safe guide to anything. ${ }^{13}$ If we had only scattered ethnographic reports that elsewhere in the world people are executed with a cocktail of chemicals one would not use on a sick cat, we might wrongly assume that the reports were false.

The word adgham is no longer current. The same idea, however, is apparent, for instance in the Barat qawa' $i d$, in the way the verb dakhkhana is used ("blackening," as with smoke from a fire), and one doubts that the effects of such blackening by bayd $\bar{a}$ ' wa-khiyār in recent centuries would have come as a surprise to early students of Kitāb al-ādāb. ${ }^{14}$ Again, man 'in the Barat material is not used in Rossi's sense and the root gives us only manū', meaning people of a locally specific status who bear arms but depend on Dhū Muhammad for their right to do so, and in-laws (even that last meaning was obscure to younger people when I worked there). Yet if we trace the word sinnah, we find it tracking the same concerns as man 'does in texts from centuries before. Those who commit shame lose their sinnah, their right to take and give protection, ${ }^{15}$ just as they lose their status in, for instance, the Bin Zinbā' text. "As for one who commits shame," says Bin Zinbā', "protecting him is not valid. If a protector gives him protection, [the protector] is shameful like him" (Abū Ghānim 1985, 363). Even the famous "return of greeting" - al-salām 'alaykum, 'alaykum al-salām - which normally makes one safe, is not valid (la yajuz). The same is true today, although judgements of who has really committed shame vary, as

13 There are certainly unfamiliar ideas in the early material. For example, payments are due for attempts to bury a man alive. Other passages raise problems of interpretation, as where amends are specified in the case of man ramā țayiran l-rājil 'alā dāri-hi (Abū Ghānim 1985, 380). In a marginal note, Serjeant has the highly unlikely heading of "Throwing poultry" crossed out in favor of "Shooting birds". Even then, I am not yet sure what the passage means.

14 Bayda 'wa-khiyār is a process of summonsing persons who have defaulted on a serious obligation such as escort, and if they fail to respond, they become liable to wounding or killing without recompense (Dresch 1987, 2017, 15-16). For a lively account of such "blaming" see Glaser (1913, 76-7, 86, 103-4).

15 The French translation of Ḥabshūsh (1995) I think slightly misunderstands the basic meaning of "something right because established practice," thus, for instance, right payment for a wrong. For the argument beyond this, where the term attaches to a person rather than an action, see Dresch $(2006,75-7)$. 
presumably they always have done. One man's wronged soul who deserves our support may be another man's villain. The salient cases of shame, however, as opposed to mere wrong, or even oppression (zulm), are those in breach of obligations such as escort and hospitality.

All our material, at whichever date, shows a concern for protected space. Physically this may be anything from the territory of a tribe to the house of a tribesman, each of which determines who is liable for what degree of payment or payment of what sort. However, space of a more abstract kind is at issue, too, in that responsibility for escort, for example can be exchanged, passed on, or rejected among members of the same tribe (Dresch 2012, 149). Also, several such spaces may be at issue simultaneously, so "If a man offends against three obligations (maläzim), for example he offends against a man who is under safeguard, and is another man's guest, and is in the guaranty of a group's market, he owes [for] three obligations" (Abū Ghānim 1985, 376). ${ }^{16}$ In each case the offender owes amends to the protector, or set of protectors, and these cases are to be distinguished from the give-and-take of compensation.

Interestingly, one finds a moral imperative to separate asymmetric relations from symmetrical claims. As we suggested earlier, the asymmetric responsibility of protector (mujawwir) for protégé $(j \bar{a} r)$, whether permanent or contextual, is an archetype, a pattern or principle on which other laws depend. To sanction the use of violence against, say, one's guest or refugee, would, in effect, be selfcontradictory. Indeed, if someone, for whatever reason, is my protégé and wrongs me and refuses to make restitution, then it is only after his "sending away" (tarhīl) that I can claim against him (Dresch 2012 , 156). So long as he is with me I must protect him against others and cannot enforce a claim I have against him personally. Once he is out of my moral space, I do so as I would against sā'ir al-nās, that is, anyone on earth.

\section{I I}

Collective moral space turns on the "inviolability of territory" (hurmat al-watan). Not only must the members of a tribe resist armed incursions by another tribe across its borders, but they must respond to wrongs done within the border to third parties by persons unrelated to themselves. ${ }^{17}$ Such persons owe the tribe amends. "The tribe," of course, may subdivide, with one part taking sides with party A in some dispute, another with party B, but whichever divisions are invoked, the logic is always the same. It is shameful to give help to those who themselves have committed shame, and to refuse help to those who have not. Around this turn legal specificities such as those of escort. Given the inherent pluralism of the tribal world, questions of right and wrong often produce divided views, but the presumption is that protection is valid unless reason exists to deny the protectors' own legitimacy.

Rulers are supposed to protect their subjects, to protect what these days are spoken of as their subjects' rights. Tribal shaykhs may be spoken of in the same terms. The householder, meanwhile, is

16 Also Rossi (n.d., 68). This should be distinguished from multiplying amends fourfold or eleven-fold. The safeguard (dhimmah) might be from one set of people, the host from another, and the market guarantors from a third. In each case the person or persons whose protection was violated would be owed amends equivalent to the cost of the damage, theft or wound, in other words payment twofold.

17 For parallels to this concern with moral sovereignty, not just vulnerability to aggression, see Jaussen $(1908,208-14)$ and Murray $(1935,315)$. In the Yemeni case, the phrase hurmat al-wațan, with the meaning outlined above, recurs at all dates. For an example, see Abū Ghānim (1985, 364, 371). 
supposed to protect his guest. But the difference between centralized and decentralized ideals has long attached to different parts of Yemen, and at the start of Kitāa al-ädāb we are told that

it will not do to reject the laws of protection (lā yajūz al-qadah fi ahkām al-man 'ah) because through them are preserved safeguards, strongholds, markets, caravans, sanctuaries (or women, perhaps; hurum) and houses, especially in the highland areas (nujūd al-buldān). As for the lowlands (tahä'im), God has given through authority (sulțān) what is not given through the Qur'ān [alone], for they [sultans or rulers] have political influence and detailed control over their subjects' affairs. (Serjeant n.d., 3)

In the former type of case (the imagined "highlands"), we find claims of tribal solidarity built around common protection of markets, hijrahs and dependent people, as well as territory, ${ }^{18}$ and breach of such protection by members of the tribe or by outsiders demands amends. However, while disagreement between tribes leads to conflict of a kind one needs only a map to follow, disagreement may as easily occur within a tribe. In cases of intransigent conflict with fellow tribesmen one could move elsewhere, of course. That is implicit in a good deal we find about "one seeking refuge" (al-mutajawwir). But claims to refuge can be divisive, as when a man who had wronged a Jew under Nihm's protection in the nineteenth century took refuge with Khawlān al-Ṭiyāl and the two tribes were placed at odds until Nihm convinced Khawlān he was in the wrong (Habshūsh 1995, 70-71). How, then, does such morality play out to different constituencies?

If someone is seen locally to have behaved abominably in local terms, they will be refused protection and told to move on, but there are very few circumstances in which anyone but a family of tribal status who themselves have been wronged directly can demand that a "foreign" refugee (one not from the protector's own group) be handed over. Even this is a delicate subject, comparable perhaps to dealing with a serious offence by a hereditary protégé. "Protecting him is disgrace, and sending him away is absolution", says Bin Zinbā'; "it is said that handing him over (taslìm-hu, i.e., to the offended party's kin) is valid. The more correct thing (al-aṣwab) is to send him away" (Abū Ghānim 1985, 363). When the claim is made in nontribal terms, perhaps by persons outside the tribal world, there is often trouble. Enraged sultans and imams are easy to find in the chronicle literature. The civil war of the 1960s was colored by this kind of issue, and the beginnings of "the Hūthī rebellion" some fifteen years ago were an object lesson to any government, though obscure to 'Alī 'Abdullāh Șālih, in how not to act. ${ }^{19}$ One could go on multiplying cases.

Relations with the outside world only highlight issues that inform both argument and agreement among the tribes themselves. Suffice it to say that a tribe that cannot offer refuge is not a tribe. No more is a man who cannot take in guests a tribesman. The details of law on escort, refuge, and hospitality all

18 The salience of refuge and protection generally are well documented, as is the importance of agreements to protect in common certain places and persons (see e.g. Weir 2007, 82, 123-4, 127 and passim). The Barat qawā'id (Dresch 2006) provide a condensed example. They also discuss, more unusually, the need to retrieve one's own tribesmen if they feel aggrieved and seek refuge elsewhere.

19 Demands that persons be handed over were one aspect of protection and tribalism encountering statist authority, another was the offer of protection on the state's behalf. I cannot forget Mujāhid Abū Shawārib in 2004 suggesting that "al-Ḥuthī" come to Șan 'à' under Mujāhid's safe conduct and the suggestion being snorted aside. 'Alī 'Abdullāh preferred a fight. In the catastrophe that grew from there, it is striking how often "tribal values," "tribal governance," or simply "tribalism" turn on the claim that refuge should be respected (Weir 2007, Brandt 2017). 
turn on the same archetype, and the principles whereby morality and protection are equated outlast the specific terms used. Martha Mundy, a very scrupulous author much concerned to distinguish the present from the past, thus mentions the term man ' $(1995,29,54,248 \mathrm{ff}$.) and forgets to stress that it is archaic, the meaning unknown to most people these days in most parts of Yemen. ${ }^{20}$ Only a small-minded person would complain. She is surely right to mention the idea, which is not obscure and is a large part of what tribalism itself is about.

I V

By "tribe" I simply gloss qabilah. ${ }^{21}$ In many parts of Yemen the Arabic term is used of, among other things, rather large sets of people, each distinct from other sets of the same kind, such as Arhab or Khārif, or Bakīl and Ḥāshid, and one of the topics the present volume highlights is variation in the forms of tribal identity. It really is about time we addressed this. The "follow-up" to early work somehow never happened, and monographs (mine, Steve Caton's, Martha Mundy's, to name a few) have sat unchanged on the landscape like so many fossil coprolites. That is not, I am sure, what any of us wanted, but in the absence of further thought, it is easy for readers unfamiliar with Yemen to assume that one account must be right and another wrong. Life is not that simple.

It is no use popping up at seminars to say that, for example, Jabal Rāzih is different from Sufyān. ${ }^{22}$ One would hardly expect it not to be, with terraced cultivation and trade routes in one, barren scrub in the other. Sufyān and Banī Șuraym are different again. Caton's account (1990) suggests that Khawlān al-Tiyāl may differ from what I lived with; Andre Gingrich on Munabbih (1987) is different from both. But what we all find, wherever we work, is that one cannot reduce tribes to solidary groups or the product of authority. For one thing, they are too long lasting. Were they simply groups of a kind that might derive from biology or from predatory alliance, then demography, famine, and sheer entropy would make the present-day map very different from that of Qāsimī or medieval times. In fact, they are strangely similar, and changes seem to have occurred by discrete quanta (Dresch 1989, chap. 9). ${ }^{23}$ But some obvious forms of politics move to different rhythms.

20 As Serjeant notes $(1950,591)$, Landberg's Glossaire includes mana' $a$ with the meaning of "to place [oneself] under protection." Weir $(2007,158)$ reports man 'in Rossi's sense from Rāziḥ. I never encountered it spontaneously used in this sense anywhere between Șa 'dah and Șan ' $\bar{a}$ ' or in the Upper Jawf.

21 The English term tribe has certain patterns of use, of course, as do German Stamm, Latin tribus, Arabic qabīlah and so forth. The patterns are not congruent. Tribus, for example, was used of the Romans themselves (and of sundry defunct Italian peoples), while other groups might be populi or gentes. If one browses the Loeb parallel text of Pliny, however, one finds "tribe" used on the facing page quite arbitrarily. Much general academic talk of tribes strikes me as akin to examining the Roman world through the English translation.

22 One can safely take Rāzih as a point of reference because we now have Weir's fine account of the area (Weir 2007). If we are looking for a simple explanation of relative degrees of practical hierarchy, we do not have to look very far - "just add water" - but the way in which a single set of terms encompasses different views of right order has hardly been examined yet. The suggestion that "Dresch ... explicitly denies the relevance of ecology" (Weir 2007, 2) is too extreme. Were that my view, I would not have discussed different forms of territoriality at length (1989) or provided such tedious detail on Barat (2006). What I would deny is that tribalism can be reduced to ecology.

23 In what al-Hamdānī depicts as the heroic age, there is an imagery not only of shared descent but of movement and conquest. See Mahoney (2016), Heiss (2018). Later such imagery recedes, although there may have been as many people moving from place to place, particularly in times of famine. Nor is change uniform. The area around al-Bawn, for instance, takes its present form later than do areas nearby. 
We all know that before Islam Hamdān was the name of a dynastic line, and only late in the day did it become the name of a set (a tribe) comprising Hāshid and Bakīl. We know of great family powers in al-Hamdānı̄'s time. We know, more recently, that several important shaykhly houses first appear in the record at the time of the Qāsimī expansion into Lower Yemen, and their prominence depended on wealth from beyond tribal territory (Dresch 1989, 204-12). Great shaykhs, in short, are an essential part of political history. Marieke Brandt (2019) has worked on the murder, in 1972, of Nājī al-Ghādir, whose prominence in the civil war depended on external funds, without which people starved. While Nājī rose and fell, however, Khawlān remains, and, whatever the political fortunes of its members, when disputes arise with members of Murād or 'Abīdah, or Bal Ḥārith in the other direction, or further afield, it matters that Khawlān and its constituent tribes exist.

The way in which it matters is apparent not only from ethnography in recent decades but from Habshūsh's account (1995) and, beyond Khawlān, from Glaser (1913). When somebody commits a wrong, others are implicated. Quite who is implicated in which way is a matter of claims and counterclaims, with rights of protection (mutual or asymmetric) being asserted, denied, or changed in form. Both Habshūsh and Glaser show what happens when a path to agreement is not evident. When sets of people find collective honor at stake, then ordinary life becomes impossible, and members of one set simply cannot be seen in the space of the other set. Many of us will have encountered instances where the alleged wrongdoer therefore has to disappear from view, either staying inside his own house indefinitely or moving outside the immediate moral world. Lower Yemen and the western mountains are usually far enough. ${ }^{24}$

In all of this, in all our sources, there is an appeal to "customary" law, hukm 'urfi. The law is not identical from place to place, nor is it changeless over time; least of all does it provide means to predict what happens. The early texts themselves, meanwhile, provoke historical questions. They ascribe to shaykhs greater prominence than one would now expect, they refer to sultans, who may be figments of wishful thinking or may denote a reality lost to other sources, and they mention ahl al-amr wa-lnahy, people concerned with Islamic righteousness, but give no indication who they may have been. ${ }^{25}$ Through all of this, however, they are consistent on protection. They are consistent on the principle that if I wrong my protégé, I owe him at least twofold; if you wrong my protégé, you owe to him recompense and a multiple of that recompense to me. We are defined by the spaces we control. And although new "custom" can come into being, these principles are treated as timeless, as given by the order of things, not by anyone's decision.

Law texts such as Kitāb al-tabyin by themselves are merely philological puzzles. Some cannot be dated at all; others may reproduce concerns that do not change, precisely because no one but an antiquarian ever found them important. ${ }^{26}$ Two things makes them interesting: one is the set of assumptions

24 Elsewhere (Dresch 2006, 199) I mentioned a friend from Barat living in Lower Yemen as the result of an intractable dispute, and pointed out that if I knew where he was, then so did others. (Since then he has been killed, but by a close kinsman, not his declared enemies). The principle at issue was "out of sight, out of mind." The same is true of seeking refuge with a nearby tribe. A contrast may be drawn with current absolutism and its insistence that enemies be hunted to the world's end (Dresch 2014, 124).

25 In both Kitāb al-āda $\bar{b}$ and Kitāb al-tabyīn there is discussion of dīwānīs, plainly mercenary soldiers in the employ of sultans or chiefs. Their rights and duties, too, are encompassed in hukm al-man'. I can see no clue as to where and when they might have been employed.

26 Nearly all the treatise material I have mentioned, as distinct from pacts and signed agreements, lacks explicit dates of 
they embody; the other is their congruence with other types of source. The details and the terms shift, but I doubt there is anything in the principles I have tried to set out that one could not illustrate, at any period, from fragmentary accounts in chronicles, in "lives" of imams, or in tarājim literature, quite apart from dispute documents of the kind that we usually have only for recent centuries. They reflect the assumption that tribalism is a matter of mutually recognized, yet indefinitely divisible, moral spaces.

As soon as one turns to law, somebody will say, "Yes, but what really happens?" At best this is an uninteresting question, and at worst it is wrongheaded. Demands for supposed "realism" ignore the local categories at issue and assume a world of asocial individuals who must somehow be disciplined through power. In reality, there are no such creatures. Yet the ideology of the North Atlantic states works as if such creatures were entirely real. This is so not least in law, where, despite the salience of "corporate persons," the dominant theme, increasingly, is of isolated natural persons answerable to state authority and protected by state authority from their equally asocial fellows.

I began by saying that modernist political discourse disguises its own longevity. The current global empire, like older empires of more limited extent, retains the assumption that somebody must be in charge. Empires, no doubt, tend that way. But the sheer naturalness of the assumption in the present case is buttressed by an enormous literature that identifies morality and law with centralized authority, regardless of political form; the idea seems equally natural in the work of J. S. Mill, in Hobbes and Locke, and in theorists of monarchy who preceded them, as if life could not be otherwise. The obvious question from within such a view of life is always, "Who is in charge? Who makes the rules here?" Usually it is not the question one needs to ask in rural Yemen. More to the point is, "Who are your guests, and why?"

References

Abū Ghānim, Faḍl. 1985. Al-Bunyah al-qabaliyyah fí al-yaman, bayna l-istimrār wa-taghyīr. Damascus. Mațba at al-kātib al-' arabī.

al-Akwa', Ismā'̄il 'Alī. 1993. Al-Madkhal ilā ma 'rifah hijar al- 'ilm wa-ma 'āqil-hu fỉ al-yaman. Damascus: Dār alfikr; Beirut: Dār al-fikr al-mu āṣir.

Brandt, Marieke. 2017. Tribes and Politics in Yemen: A History of the Houthi Conflict. London/New York: Hurst/ Oxford University Press.

2019. "A Tribe and its States: Yemen's 1972 Bayḥān Massacre Revisited.” Middle Eastern Studies 55 (3): 319-338.

Caton, Steven. 1990. "Peaks of Yemen I Summon": Poetry as Cultural Practice in a North Yemeni Tribe. Berkeley: University of California Press.

Dresch, Paul. 1987. "Placing the Blame: a Means of Enforcing Obligations in Upper Yemen." Anthropos 82:427-443. 1989. Tribes, Government, and History in Yemen. Oxford: Clarendon Press.

composition or copying. Most of these texts, though not all, have parts missing, particularly at the start and finish. For the moment, I doubt the lack of dates has any great significance. There is little doubt, however, that passages may be copied from other works without necessarily being understood. 
2006. The Rules of Baraț: Tribal Documents from Yemen. Șan'ā': Centre Français d'Archéologie et de Sciences Sociales, Deutsches Archäologisches Institut.

2012. "Aspects of Non-State Law: Early Yemen and Perpetual Peace." In Legalism: Anthropology and History, edited by P. Dresch and H. Skoda, 145-72. Oxford: Oxford University Press.

2014. "Outlawry, Exile, and Banishment: Reflections on Community and Justice." In Legalism: Community and Justice, edited by F. Pirie and J. Scheele, 97-124. Oxford: Oxford University Press.

2017. “Rossi’s Kitāb al-sinna: a seventeenth-century note of tribal law in Yemen." Arabian Humanities 9. http://journals.openedition.org/cy/3489.

Gingrich, Andre. 1987. “Die Bani Munnebih des nördlichen Khawlān: Einige vorläufige Ergebnisse ethnologischer Forschung in der AR Jemen.” Sociologus 1 (37): 89-93.

Glaser, Eduard. 1913. Eduard Glasers Reise nach Marib, edited by D. H. Müller and N. Rhodokanakis, Vienna: Alfred Holder.

Habshūsh, Haȳ̄m. 1995. Yémen, edited and translated by Samia Naïm-Sanbar. Arles: Actes Sud.

Heiss, Johann. 2018. "Migrations and Federations: the Origins of the Tribal Federation of Khawlān According to al-Hamdān̄̄." The Medieval History Journal 21 (2): 365-379.

Jaussen, Antonin. 1908. Coutumes des Arabes en pays de Moab, Paris: Gabalda.

Mahoney, Daniel. 2016. “The Political Construction of a Genealogy from Early Medieval South Arabia.” In Meanings of Community Across Medieval Eurasia: Comparative Approaches, edited by E. Hovden, C. Lutter and W. Pohl, 163-82. Leiden: Brill.

Mundy, Martha. 1995. Domestic Government: Kinship, Community and Polity in North Yemen. London and New York: I. B. Tauris.

2013. The Solace of the Past in the Unspeakable Present: the Historical Anthropology of the "Near East," third annual Goody Lecture, 18 July 2013, Max Planck Institute for Social Anthropology. https://www.eth. mpg.de/3790211/Goody_Lecture_2013.pdf.

Murray, G.W. 1935. Sons of Ishmael. London: George Routledge.

Pitt-Rivers, Julian. 1977. The Fate of Schechem, or the Politics of Sex. Cambridge: Cambridge University Press.

Rossi, Ettore. 1948. "Il diritto consuetudinario delle tribu arabe del Yemen." Rivista degli Studi Orientali XXIII: 1-36.

n.d. Kitāb al-tabyīn fi l-man', transcribed by R. B. Serjeant, Serjeant archive, University of Edinburgh GB 237 Coll-1062, Box 7.

Scheele, Judith. 2014. "Community as an Achievement: Kabyle Customary Law and Beyond." In Legalism: Community and Justice, edited by F. Pirie and J. Scheele, 177-200. Oxford: Oxford University Press.

Serjeant, R. B. 1950. "Materials for South Arabian history (part two)." Bulletin of the School of Oriental and African Studies 13 (3): 581-601.

1991. Customary and Sharī ah Law in Arabian Society. Aldershot: Variorum Reprints.

n.d. Kitāb al-ādāb wa-l-lawāzim fi hukm al-man', photocopy transcription in the possession of Paul Dresch.

Stewart, Frank. 2000. “Urf (Arab Customary Law).” In New Encyclopaedia of Islam 10, edited by P. J. Berman et al., 888-892. Leiden: Brill.

Weir, Shelagh. 1996. "Documents from Rāzị̣ as Anthropological and Historical Sources." Proceedings of the Seminar for Arabian Studies 26:167-73.

2007. A Tribal Order: Politics and Law in the Mountains of Yemen, London: British Museum Press. 


\title{
SOME REMARKS ON BLOOD VENGEANCE (THA ' $R$ ) IN CONTEMPORARY YEMEN
}

\author{
MARIEKE BRANDT \\ Amā al-tha'r fa-huwa sharr lä budd min-hu li-l-hafäz 'alä l-hayyāh. \\ "Blood revenge is an inevitable evil in order to stay alive."
}

\section{Introduction}

Blood revenge (tha' $r$ ) is a customary social activity of great violence, which nevertheless involves the careful following of culturally prescribed rules. Tribal customary law ('urf) considers blood revenge a legitimate - albeit rather rare - form of physical violence, which means that if killer kills victim, then it is in certain circumstances legal for a member of the victim's group to kill a member of the killer's group - and, in particular, the killer himself. ${ }^{1}$ The rancorous deed of taking revenge is interconnected with strong feelings of justice and moral order. This short definition already indicates that the concept of blood revenge seems to combine a number of contradictions; an ambiguity that a shaykh of the Wầ ilah put in a nutshell by telling me: "Blood vengeance is an inevitable evil in order to stay alive." In the rhetorical figure of an oxymoron, he conveyed an ostensible self-contradiction - that is, homicide in order to protect life - to illustrate the paradox of blood vengeance.

I started to take an interest in the phenomenon of blood vengeance when I worked on my book on the Șa 'dah wars (2004-2010) and the history of the Hiuthī conflict, whose local roots go back to the mid1930s (Brandt 2017a). In order to understand the matrix of this war, on the local and community level, I was not only interested in exploring the positions taken by certain individuals and groups, but also their very motivations for adopting those positions. My particular interest in family histories, phenomena of longue durée, and the eternal question of the "why" revealed that in most cases family and tribal patterns of alliance and enmity preceded and determined the political and sectarian array of the actors. A notable, albeit extreme example is the historical feud between the tribes al- 'Ușaymāt and Sufyān that arose in the $19^{\text {th }}$ century from a territorial conflict, which itself had roots in the struggle for influence and leadership between two prominent shaykhly lineages that goes back to the time of the first Ottoman

1 I would like to thank the participants of the workshop "Yemen's Living Heritage: Tribes and Tribalism into the $21^{\text {st }}$ Century" (14-15 February 2018), in particular Andre Gingrich and Najwa Adra, for their comments on the manuscript draft of this article. Special thanks go to my Yemeni informants, who prefer to remain anonymous. The Austrian Nationalstiftung FTE and the Institute for Social Anthropology at the Austrian Academy of Sciences supported this research. This brief summary of the concept of blood revenge is based on the definition given in $\mathrm{EI}^{2}, 2000$, Vol. X, pp. 442-43.

2 Due to the current inaccessibility of the research area, this chapter is based on a mixed-method approach, consisting of literature-based research and digital anthropological fieldwork (distance approach). For further details on digital fieldwork in wartime Yemen, see Brandt 2017b. 
period (1538-1635). Down to the present day, this feud continues to force these tribes into diametrically opposed political and sectarian positions: whatever happens, Sufyān will always do the opposite of al'Ușaymāt. Antagonisms of this kind are the tangled underwood of political history in Yemen.

The deep currents of enmity, retaliation and feuding usually remain elusive for the external observer. Rarely will they suddenly become as evident as in the assassination of Yemen's former president 'Alī 'Abdullah Șālih in December 2017 by the Ḥūthīs, after which Șāliḥ’s son Aḥmad declared, "We will take revenge on the enemies of the homeland and of humanity, and we will see their punishment" (Almasdar Online 2017). Șāliḥ's death itself and the media display of his body were considered the revenge for Ḥusayn al-Ḥ̂thī's killing and the media display of his corpse during the first Șa dah war in 2004. In fact, the close-up images of the slain Ḥusayn al-Ḥuthī and 'Alī 'Abdullah Șāliḥ that were circulating in the media, both men killed by a gunshot point blank to the head, displayed a certain degree of similarity: parity had been restored, in more than one sense.

Customary practices of blood revenge can be observed in many societies all over the world. To this day, traces of this pattern of thinking and behavior can be found in the most surprising places. We recall when, in May 2011, former US president Obama announced that Osama bin Laden had been killed in Abbottabad, Pakistan, he issued a declaration that "Justice has been done." The next morning the New York Post headline read "Osama bin Laden Dead: Got Him, Vengeance at Last! The U.S. Nails the Bastard" (Hénaff 2011; Dumouchel 2012). More recently, we read in the news that, in a bizarre attempt at atonement, the Saudi government offered blood money (diyah) as a financial compensation to the family of journalist Jamal Khashoggi, who was killed in October 2018 in a Saudi consulate (Middle East Eye 2018). Despite the diversity of these cases and their contexts, it becomes clear that blood vengeance is still, albeit difficult to frame theoretically, an existing legal and cultural phenomenon.

This chapter aims at gaining a deeper understanding of the phenomenon of blood vengeance in the tribal societies of contemporary Yemen, with a particular focus on tribal highland Yemen north of Șan ' $\bar{a}$ '. It discusses the legal basis of blood revenge in tribal customary law, and explores the reasons for the changes that the practice of blood revenge has undergone in recent decades. By looking more closely into the topic, it becomes clear that talking about blood revenge is not that simple, and that an ethnographically informed analysis of the phenomenon has to take into account the wider ethnographic context and the theoretical framework that evolved around it. Although the definition of blood revenge given at the beginning of this chapter may sound quite clear, the Yemen example underscores the observation that in reality things are less tidy than in theory. The process of "dilapidation" and "degeneration" of the practice of blood vengeance recently observed in Yemen illustrates the problem that blood vengeance remains a polymorphous phenomenon whose ambiguity continues to obstruct the generation of a viable theoretical framework. By considering the Yemen example, this chapter argues that the impact of socio-political change and massive politicization of conflict render the scientific consideration of the phenomenon of blood revenge more difficult than ever.

\section{A Disputed Concept}

The reception of the concept of blood vengeance has experienced a changeful destiny that bears similarities to the reception of the concept of "tribe." Both concepts received much attention in the early $20^{\text {th }}$ century, in the context of massive cultural contact through colonialism. Both concepts were then questioned and even avoided for decades, but have experienced a kind of renaissance in recent years. Today anthropology, history, criminology, theology and other disciplines are active in the study 
of modern and medieval blood revenge. The topic has created a huge literature, but this amount of work has not yet brought about an accepted definition. Because of the difficulties in definition, and its inherent polymorphism, blood revenge, like tribe, remains a controversial concept.

Further ambiguity is added by the fact that in anthropology, the discussion of blood revenge and feuding is closely tied to segmentary theory. Segmentary theory was introduced in the beginning of the $20^{\text {th }}$ century by Émile Durkheim (1893). In the anthropology of the Middle East, segmentary theory is associated with the works of Edward Evans-Pritchard (1940) and Ernest Gellner (1981). According to segmentary theory, a segmented society is not governed by central political institutions, but is subdivided into mutually equivalent solidary groups (that is, lineages or segments or clans) that are organized in the form of a nested hierarchy. The broad idea of segmentary theory is, or was, that in the absence of effective leaders, order and the balance of power are maintained by collective action: equivalent groups at different levels of the system mobilize in response to threats, then dissolve when they abate. In considering the phenomenon of blood revenge, segmentary theory has been used to conceptualize the composition of vengeance groups and groups that raise the blood money (diyah, the material compensation paid by the killer or his group to the kin group of the victim in order to avoid revenge killing). In practice, however, things prove to be less tidy than suggested by segmentary theory, and on most occasions segmentary theory fails to fully explain the complex mobilization patterns that take place in the vengeance process. The variables not considered by segmentary theory include, for example, the fact that mobilization due to common descent does not necessarily take place along purely "segmentary" patterns, as Emrys Peters (1967) has observed among the Bedouins of Cyrenaica and John G. Hartley $(1961,184-87)$ among the Nahd tribe of Haḍramawt. Shelagh Weir $(2007,191)$ argues that in the tribal society of Rāzih, collective segmentary mobilization is counteracted by the tribal imperatives of conflict diffusion and mediation. Steven Caton $(1987 ; 1990$; and his chapter in this book) observed that in Khawlān al-Ṭiyāl and elsewhere in tribal Yemen, a powerful driver of collective mobilization in times of conflict is persuasion through language and poetry, rather than segmentarism. What we all find, wherever we work, is that tribes and descent communities cannot always be reduced to mere solidary groups. On the other hand, on a structural level, the perceived common ancestry of tribal societies indeed corresponds to the common visual representation of tribes as nested hierarchies or "segmentary groups," hence the concept of segmentation remains a useful tool for illustrating the treelike structures and genealogies of tribes that divide and subdivide in the manner of the branches of a tree, though there is no central and pre-eminent trunk, all branches being equal. Paul Dresch $(1986,309)$ therefore suggested that although segmentary theory (which deals with sequences of events) should be applied with due caution, the simpler structural idea of segmentation (which deals with formal relations) that underlies it retains an explanatory value.

Another reason that complicates the scientific consideration of blood vengeance and blood feud is that the subject at first glance seems to confirm negative prejudices against tribes and tribalism and their perceived "cruelty" and "violence." Negative views are widespread among non-specialist foreign observers and have a long tradition even in Yemen, especially in urban areas and in less tribal Lower and Southern Yemen, whose populations in history have repeatedly been raided by northern tribes. ${ }^{3}$

On these raids of the northern tribes, in particular the tribes of al-Jawf, on Șan ' $\bar{a}$ ' and Lower Yemen, see, for example, al-Amri 1985; Dresch 2006, 67-69. 
The imams of Yemen, whose power ultimately depended on the tribes' support, condemned tribal customary law as țaghūt (roughly: "idolatrous practice") and tried to replace it with Islamic law (Rossi 1948; Rathjens 1951). After the revolution of 1962, intellectual authorities such as Ahmad Muhammad Nu'mān $(1965,33)$ and others continued to communicate prevailing apprehensions and fears. Today, in times of foreign intervention and civil war, Yemen's northern tribes have again suffered a loss of image and are blamed for the violence and atrocities that are inflicted on Yemen's population on behalf of the Hūthīs, even though tribesmen in 2011 played a central role in the support and protection of Yemen's "Change Revolution" (Adra 2016).

\section{Blood Vengeance}

In Yemen, as in many tribal societies of North Africa and the Middle East, blood vengeance is an honorbound concept. Jamous (1992) describes honor (sharaf) as a cultural entity that governs the life and the beliefs of individuals within these societies: Honor defines the encompassing ideology of a society and is embedded in its social structure, whose coherence as a whole it renders comprehensible. In tribal Yemen, the honor of an individual is simultaneously part of the tribal section's or tribe's collective honor, and vengeance is a response to the perceived violation of individual or collective honor. ${ }^{4}$ Individual and collective honor can be infringed by disgraceful action or talk (subsumed by the term 'ayb), and the infringement of honor requires amends. For this reason, not only physical harm must be repaired, but every harm affecting individual or collective honor, either by financial or physical compensation.

The "negative balanced reciprocity" inherent in the concept of blood revenge, particularly of blood feud (see below), is a salient feature of many societies characterized by weak or absent state power and competing factions or kin groups for which individuals feel their principal social belonging and obligation; honor is typically a moral value of paramount importance. Marshall Sahlins (1965), drawing on Marcel Mauss (1990, orig. 1925), argued that negative reciprocity entails an exchange of harmful actions between two distinct parties. A particular person harms a member of another family; the harmful act might be theft, the destruction of property, or a physical assault, all having the effect of lowering the social prestige or honor of the victim since he and his family are made to appear as weak and defenseless. In retaliation, members of the bereaved family harm the perpetrator or a member of his family, thereby demonstrating strength and determination to defend the family (or group) and its honor. This "exchange of harms" has a tendency to escalate: harm turns into vengeance, vengeance turns into feud, and feud can wipe out an entire family or group. Examples of such social settings in European history are Corsica (Wilson 1988), Friuli (Muir 1993), and Calabria (Brögger 1971).

In Yemen, the process of blood vengeance is governed in detail by the rules of tribal customary law ('urf), hence it would be wrong to equate blood vengeance with lawlessness or social disorder. Blood revenge is more a process than an isolated event, and the rules of the process differ from tribe to tribe. A comparison of more recent Yemeni studies on tribal customary law written by Faḍl Abū Ghānim (1985), Rashād al- 'Alīmī (1988) and Muḥammad b. 'Alī Șayyād (2014) shows that there are differences between the tribal societies of Yemen regarding their customary legislation: Sufyān has other rules and procedures than Arḥab; Khawlān al-Ṭiyāl has others than Murhibah. Hence, also contemporary local

On the concept of honor in tribal Yemen, see Dresch 1989, 38-74; Weir 2007, 49-51; Adra 1982, 142-144. 
customary law documented in different areas and among different tribes by Dresch (1989 and 2006) and Weir (2007), has its peculiarities in terminology and procedures. Furthermore, the consideration of the history and roots of Yemeni customary law, as undertaken by Dresch (see his chapter in this volume), opens up a universe of complexity and detail. In any case, and to sum it up, the process of managing and implementing vengeance involves complex rules and rituals and the involvement of many persons in different functions: mediators, arbitrators, guarantors, solidary groups, and vengeance groups.

In Yemen, blood vengeance becomes the means of choice to restore individual or collective honor only in connection with certain cases of homicide. Yemeni customary law distinguishes between accidental and deliberate homicide. ${ }^{5}$ In order to set the penalties related to homicide, customary law classifies killings into a number of categories - three, in most but not all cases - that depend on the types of ' $a y b$ (disgrace) exhibited by these homicides. The different types of ' $a y b$ are assigned colors (white, red, black, sometimes yellow) that determine the gravity of the infringement: white 'ayb designates the least severe form, black 'ayb the morally most reprehensible kind of homicide. ${ }^{6}$ The colors of ' $a y b$ are also applied to other misconducts like theft, looting, or even lying and false testimony. I am well aware that this is a much-generalized depiction of the intricate and locally diverse classifications and rules of Yemeni customary law in regard to homicide. As mentioned above, Yemeni tribes differ in their legalistic conceptions, interpretations and practices.

Accidental killing (qatl khața') is usually considered "white disgrace" ('ayb abyaḍ). White 'ayb can be unintentional homicide such as a traffic accident, but also homicide during a war, that is, in a situation where those involved know that it will be necessary to kill people. White 'ayb usually results in the amount of a single unit of blood money (diyah) that the culprit has to pay to the family of the victim to avert his killing in revenge. Although the amount of the diyah differs from tribe to tribe, it always takes, in the words of Weir $(2007,162)$, the form of "a massive sum" and "weighty deterrent." In 2018, one unit of diyah in al-Jawf amounted to approximately 6 million Yemeni Riyals. ${ }^{8}$ In addition, fines must be paid to the leaders of the tribe in which the homicide took place. These payments can take different material forms: money, food, animals, sometimes rifles. In many cases of white ' $a y b-$ a tragic, unintentional accident, for example - tribal customs encourage a further reduction or even revocation of the penalty. The reduction of the punishment aims at maintaining the (good) relations between the families of the victim and the offender. If it comes to the payment of blood money, it is usually paid in several installments, also with the aim of maintaining contact and communication between the families involved.

5 The following elaboration is mainly based on the above-mentioned Yemeni studies by Abū Ghānim (1985, 251-298), al- 'Alīmī $(1988,69-74)$ and Șayyād (2014). Other highly recommended sources on Yemeni contemporary customary law are Dresch (1989 and 2006) and Weir (2007). In addition to accidental and willful killing, al- 'Alīmī (1988, 70) refers to the third category of "hidden killing" (qatl majhūl), that is, if a corpse is found but no culprit can be identified. In this case, the responsibility for enacting the material compensation for the victim's family lies with the tribe on whose territory the body was found. The categories qatl khata' and qatl 'amd roughly correspond to the categories of negligent homicide and murder that are adopted by many other legal systems all over the world.

6 On the notions of "black" and "white" in the moral system of Yemen's tribal societies, see also Dresch 1987.

7 The concept of financial compensation through diyah is not only part of customary law, but also - in principle - part of Islamic jurisprudence also practiced in Yemen. We will briefly return to this matter further below.

8 According to a source from al-Jawf. In 2018, six million YR approximately equated to 24,000 USD. 
The second category of homicide falls within the scope of "red disgrace" ('ayb ahmar). Red 'ayb includes, for example, the victim of an accidental killing being a child or a woman, whose life often but not always - is valued at four times as much as a man's life, or homicide that occurs in the course of a mediation or arbitration process during which, according to customary law, the parties to the conflict are obliged to refrain from vengeance. The penalty for red ' $a y b$ is the payment of fourfold blood money, that is, the culprit is obliged to pay four diyah to the family of the victim in order to settle the blood debt and prevent a killing in revenge. ${ }^{9}$

The third type of homicide is willful or deliberate killing (qatl 'amd). Willful killing divides into two subcategories: First, manslaughter or heat-of-passion killing, when a defendant is provoked to commit a homicide or when a provocation induced rage, anger, or fright. Second, murder (qatl nakir), considered the most reprehensible type of homicide, especially if it features aspects of treachery (khiyānah) and betrayal (ghadr). Willful killing falls into the category of "black disgrace" ('ayb aswad). Each aspect of black ' $a y b$ in a crime requires the payment of eleven-fold diyah by the slayer or his kin to the slain's group in order to avert the slayer's killing in revenge. If a crime displays multiple features of black 'ayb, the penalty will increase accordingly. Particularly disgraceful crimes can result in penalties of multiple eleven-fold diyah that have an enormously deterring effect. Moreover, the higher the diyah, the less likely the peaceful solution of the case through material compensation becomes, and compensation in kind - tha' $r$ - is imminent. The rule of eleven-fold multiplication of the diyah according to the aspects of black 'ayb displayed by a "black" crime is called hukm al-muhaddash. ${ }^{10}$

Particularly disgraceful aspects that fall into the category of black 'ayb are, for example, the willful murder of a person who belongs to a group that enjoys special protection, as the imperatives of protection occupy a central place in tribal law in Yemen (Dresch 2015, 60-65 and his chapter in this volume). A breach of the duty of protection can be the killing of a guest (qatl al-dayf), a protégé (qatl haliff, that is a person who enjoys the protection of a tribe but does not belong to it by blood), a fellow traveler (qatl al-sayr), or a sayyid with hijrah protection. ${ }^{11}$ Black 'ayb is also the killing of a mediator, arbitrator or guarantor during a truce or during the process of customary mediation or arbitration. Also, killings that take place in special protected places are considered as black 'ayb, for example on public streets, in markets, hijrahs or in places where customary law is dispensed - places that are, according to customary law, neutral zones (manātiq muhâayyidah) whose inviolability is in the public interest. ${ }^{12}$ Black 'ayb are also particularly infamous crimes, such as rape with murder, murder with burning or hiding of the victim for reasons of concealment, looting with murder, armed robbery with murder, etc.

During the fieldwork for my book on Yemen's Șa dah wars, I was told about a case of blood revenge in 'Amrān that happened in the 1980s. An unarmed 14-year-old, who happened to be the son of a shaykh,

9 In this regard, there are differences between the tribes' customary laws. Dresch $(2006,90)$ confirmed the payment of fourfold diyah for a woman in central and eastern highland Yemen, whereas Weir $(2007,162)$ observed that in Rāzih a woman's diyah was up to half of that of men.

10 According to local sources, the original expression is probably hukm al-ahad 'ashr (lit. "the rule of the eleven") which would have evolved into hukm al-muhada'sh or hukm al-muhaddash.

11 The sāda (sg. sayyid) are descendants of the Prophet Muhammad through his daughter Fātimah. By virtue of their "noble" descent, they form a distinctive social stratum. A hijrah (pl. hujar) is a place or a person under special tribal protection.

12 By virtue of its hijrah status, in past times Șan 'à' was called makhzan al-ru' $\bar{u} s$ (head store) - a metaphor for its status as a sanctuary for those threatened by blood revenge, see 'Umar 2004, 186-87 and Serjeant 1983, 39-43. 
was killed on the public highway after he had taken his murderer along in his car. ${ }^{13}$ In their wrath, the shaykhs of the slain victim's tribe resorted to a hardline interpretation of tribal law and calculated the penalty for this crime 59-fold: 4 diyah for killing an adolescent, 11 diyah because of killing him without cause, 11 diyah for killing him on a public road, 11 diyah for killing a travel companion, 11 diyah for the killer's initial denial of guilt, 11 diyah for the concealment of the crime and the long-time exposure of the victim's corpse to decay in the sun. The penalty for the murder amounted to 372 million Yemeni Riyal (at today's values) to be paid by the slayer or his kin to the kin of the slain in order to prevent his murder in revenge. Since the crime was particularly disgraceful, and because the blood money has not been paid, the victim's people had little option but to seek vengeance in kind, and the slayer was shot dead by relatives of the victim. In another case that happened in 2013 in Hadramawt, the killing of a prominent shaykh at a security checkpoint resulted in a diyah debt of 1 billion Yemeni Riyal plus 20 cars plus 202 rifles. $^{14}$

Although responsibility for homicide and the duty of exacting vengeance fall directly on the close agnatic kin of the slayer and the slain, the communities to which the two parties belong are, in one way or another, involved in the process that ensues. The vengeance group (awliy $\bar{a}$ ' al-dam, lit. "custodians of the blood") will almost always include the closest adult male agnates of the slayer and the slain. The vengeance group also functions as a blood-money group, and has explicit rules regulating such matters as the distribution of the received blood money among its members and the circumstances under which members are to contribute to blood-money payments. Beyond this, and as we have seen in the discussion of segmentary theory, there is a great deal of variability as to who else belongs to the vengeance group: the killer's family, the tribal segment, or the whole tribe? Dresch $(1989,84)$ observed different categories: If a man kills an outsider inadvertently, the blood money would be raised by his section. If he kills in defending his honor, then the whole tribe should contribute. If he kills deliberately and/or treacherously, he should be left to pay by himself with whatever help he can muster from his kin and neighbors. The same indeterminacy extends to the question of who is obliged to kill in revenge and who is liable to be killed. The kinsmen of a slain man will try to kill the slayer, but they have a right to kill any of his close agnates. In other words, the mobilization patterns of blood revenge do not actually work out in a purely "segmentary" way. This ambiguity in regard to the composition of vengeance groups has been observed in many tribal societies in and beyond South Arabia.

Blood debt is not time-barred. Many years can pass between a homicide and its vengeance. In the 'Amrān case referred to above, the boy's kinsmen were able to hunt down and kill the slayer, who had influential protectors, only ten years after the murder. The long breath and longevity of blood vengeance is expressed in the proverbial saying "Revenge is a drop of blood that does not rot nor decay" (al-tha' $r$ nuqtat dam là tata'affan wa lā tasūs).

13 This case was narrated to me by one of the involved shaykhs. The murder of the boy was the beginning of an epic blood feud between two shaykhly families, which claimed dozens of deaths and is still unresolved.

14 At that time 1 billion Yemeni Riyāl amounted to approximately 5 million USD, see al-Aḥmadī 2014. 


\section{Blood Feud}

If we accept blood vengeance as a mechanism for the customary restriction of violence, we must face the fact that it can also be a factor that contributes to the continuation of violence. In certain cases a revenge killing does not lead to the restoration of balance (mizzān) between the groups involved, but causes further violence. This can happen, for example, if the offender's group considers itself unjustly charged or does not agree with the level of the penalty. The implementation of the vengeance process, too, can lead to further conflict, because in order to restore its honor, the dishonored group sometimes exaggerates it, and thus, with its vengeance, it does not repair but in fact further destroys the possibility of a balanced degree of violence. In such a case, the kinsmen of the (slain) slayer might not recognize parity but insist on renewed retaliation on the original victim's kin to wipe out the perceived violation of their honor. Through this process of "negative reciprocity" (Sahlins), blood revenge can develop into a cycle of retaliatory violence and permanent hostility that leads to a succession of murders, called a blood feud.

In the course of a blood feud, larger groups are at risk of being ensnared in the chain reactions of reciprocal violence. By wreaking vengeance indiscriminately on any member of the rival group, a blood feud is difficult to channel into litigation; a dispute between two families may be checked at any stage but it becomes increasingly difficult to do so as the involved groups expand. These intra- and intertribal feuds can span generations. ${ }^{15}$ A study on tribal feuding in the governorates of al-Jawf, Ma' rib, and Shabwah found that of the 164 deadly conflicts involving the tribes in these governorates, only 35 were reported by the shaykhs to have started between 2001 and 2005, while 22 had started between 1996 and 2000, 14 between 1991 and 1995, 26 between 1986 and 1990, and 67 in 1985 and earlier. One conflict was stated by the shaykhs to have remained unresolved for 92 years (NDI 2007, 10-12). ${ }^{16}$ In addition, there are countless "ancient" enmities between tribes that periodically flare up and claim scores of victims in their course. Some of these feuds are of indeterminate age and were precipitated by rivalries or conflicts over land or resources, with each tribe claiming ownership. In the course of these feuds, the original causes of the dispute fade into the background and are overshadowed by the immediate impact of reciprocal revenge killings. Examples are the feuds between Sufyān and al- 'Ușaymāt, al- 'Ușaymāt and 'Udhar, Sufyān and Arḥab, Dhū Ḥusayn and Dhū Muḥammad, Wā'ilah and Dahm, Hamdān al-Jawf and Shawlān, Khawlān und Qayfah, Āl Ḥajayzah and Āl 'Umayrān in Ma' rib, etc. However, albeit these eruptions of violence are always marked by martial rhetoric, large groups are seldom mobilized over a long period of time. As Caton (1987, 1990 and his chapter in this book) notably observed, despite their often alarming appearance and the eruptions of violence they cause, tribal values strongly condemn the heedless use of violence and warn against pushing violence too far, instead opting for solving problems through communication and persuasion.

Despite the considerable longevity of these feuds, the Hadramawt example shows that there are examples for successful mediation between the feuding groups. In $19^{\text {th }}$ century Hadramawt, the struggles

15 Gellner $(1981,97)$ recalled an anthropologist doing fieldwork in Hadramawt, observing negotiations for the settlement of a feud, and hearing to his astonishment that one of the deaths had been caused by an arrow - a weapon not in use in the region for a very long time: the accountancies of reciprocal killing stretched back right into an age of long-past military technology.

16 In his Esquisse (1972), Bourdieu presented similar material on these "chronic" conflicts. 
for power that preceded the establishment of the Qu'ayțī and Kathīrī states had created intertribal fighting that continued well into the $20^{\text {th }}$ century. Tribal fighting led to blood debts and feuds, in which any males of the tribe guilty of a killing were liable to being killed at the age of 15 . The insecurity produced by feuding paralyzed the country and obstructed agriculture and other forms of productive activity; many Hadramis emigrated either to escape the fighting or to make money to help their tribe finance its participation in the fighting (Boxberger 2002, 40). In his study on the settlement of this feud, 'Abd al- 'Azīz al-Qu'ayțī (2009) describes how by the mid-1930s, Britain's geopolitical interest in bringing stability to the region coincided with the urgent desire of leading Hadramis to establish peace and security in their turbulent homeland. After a long and arduous mediation process, the rulers of the Qu'ayṭ̂̄ und Kathīrī statelets, supported by the British official Harold Ingrams, succeeded in negotiating a truce, signed by some 1400 tribal leaders. ${ }^{17}$ Hartley $(1961,192)$ argues that this initiative succeeded in ending hostilities because the tribesmen wanted peace and because the British authorities, together with the Qu'ayțī and Kathīrī rulers, had the power to effect settlement by force if necessary. Examples like the "Ingrams Peace" disprove the thesis of Black-Michaud (1975), who holds that a blood feud is by definition "interminable."

Blood debt is one of the few factors that can bring about a consensual shift of boundaries between hostile tribes or segments (Dresch 1982, 98); borders that are otherwise often stable over hundreds of years. Since in Yemen, the protected space on which honor depends is often identified with territory, infringements of honor and the blood debt resulting from them can be compensated for by land transactions. An example from the history of Yemen is the feud between Sufyān and Dhū Muhammad. In the tenth century CE, Sufyān had a strong presence in northern al-Jawf. In a battle between both tribes, Sufyān killed 112 Dhū Husayn, whereas Dhū Husayn killed 70 Sufyān. Hence the death of 42 victims had to be avenged by Dhū Ḥusayn on Sufyān. In consequence, Sufyān withdrew from northern al-Jawf, and Dhū Husayn took the Sufyān territory in al-Jawf as material compensation for the unavenged death of 42 of their members (Brandt 2016, 135).

A similar case from present-day Yemen is the feud between $\bar{A} 1$ Talīd and Āl Thābit, both of them segments of the Jumā'ah tribe in western Șa dah province. In 1934, the Treaty of Țâ' if that defined the border between Yemen and Saudi Arabia placed Āl Talīd on the Saudi side of the boundary but failed to demarcate this section of the border on the ground due to tribal conflict. Over the decades, the feud between $\bar{A} 1$ Talīd and Āl Thābit sparked chain reactions of reciprocal violence claiming dozens of lives. In 2005, shaykhs of the neighboring tribes successfully managed to arbitrate in this conflict. The customary settlement provided for the cession of territory from $\bar{A} l$ Talīd to $\bar{A} l$ Thäbit, in order to settle the blood debt and thereby restore the balance between the tribes. The shift of the tribal border between $\bar{A} 1$ Talīd and Āl Thābit, an intertribal border that constitutes a part of the (ceasefire line and) state border between Yemen and Saudi Arabia, has brought about an adjustment of the course of the international border recognized by both governments (Brandt 2017a, 79, 85-86; al-Fayfī 2009).

Basically, however, blood vengeance and blood feud are worst-case scenarios that seem to occur far more frequently in arid and steppe areas of Yemen. Among the sedentary tribes of highland Yemen with their well-defined borders and strong agricultural background, blood revenge, feuding, and armed raids are rather rare. Tribal law and custom, while ready in the proper circumstances to countenance and

17 On the settlement of these feuds, see also Harold Ingram's account (1942, 258-311). 
regulate blood revenge, do not encourage it, and instead offer a variety of institutions and procedures whose effect is to produce peaceful settlements. Beyond this, Islamic jurisprudence also strongly discourages blood feuds: The Prophet Muhammad wishes his followers to live in friendship (Surah 8, 72). Hell awaits those who try to complicate things again (Surah 2, 178-179). Honor does not justify any exaggeration. Only the deliberate killer should be killed; the tribal custom of exacting vengeance on any member of the slayer's agnates is in contradiction with Islamic law. Since its foundation, Islam has sought to contain and limit the scope of blood revenge and tried to promote communal cohabitation. The concept of blood money recommended by the Quran aims to terminate the potential spiral of violence at an early stage. Islamic law recommends diyah solutions through financial compensation to the victim or the heirs of a victim in the cases of murder, bodily harm or property damage and strongly discourages equal retaliation (qișass ) through revenge. ${ }^{18}$ Scholars upholding Islamic law condemn the customary practices of killing a member of the kin group of the killer, reciprocal killings and multiple revenge (such as hukm al-muhaddash) as țăghūt (Rathjens 1951; Dresch 2006, 90).

\section{Exploiting Violence}

The Weberian understanding of statehood suggests that the customary practice of blood vengeance declines as the state consolidates its monopoly on force. According to this understanding, there is a straight path from blood vengeance to policing, that is from clan or tribe societies to societies whose public force is executed by a specialized body of law enforcement (Weber 1922, 561). Weber sees blood vengeance as a tool of political violence that has been successively eliminated by the monopoly of violence of the modern state and its most visible organ of representation, the police. The Weberian understanding of statehood regards blood revenge as a form of violence regulation that loses importance in societies where an effective apparatus of law and law enforcement is able to wield control; societies that Girard $(1972,38)$ called sociétés policées.

Against this background, it is an interesting fact, and one worth noting, that national statistics from the period between the 1994 civil war and the 2011 "Change Revolution" observed two trends in Yemen: first, an increase in blood revenge cases in Yemen, and second, the growing non-compliance of these revenge cases with the rules of tribal customary law. ${ }^{19}$ According to these studies, the observed "degeneration" (tafassukh) of the process of blood revenge manifested itself in the fact that revenge killings increasingly began to take place in public places such as markets, towns, and public roads, whose inviolability is anchored in tribal customary law, and that the violence of retaliation was no longer exclusively directed against the slayer and his agnates, but also against women and children. As a result, in some areas, the balance (tawāzinn) and stability (istiqrār) of the tribal societies of Yemen have been undermined and public life paralyzed, similarly to what happened in Hadramawt in the late $19^{\text {th }} /$ early $20^{\text {th }}$ century. State-sponsored studies mainly blame this development on the "predominance of tribalism" (haymanat al-nizām al-qabalī) and "negative traditions of tribal customary law" (al-taqālìd

18 Tyan 1963, 350-352; Schacht 1993, 185.

19 See the collective volume Zāhirat al-tha'r fì al-Yaman edited by Nașr Ṭaha Mușțafā (2004) and sponsored by the Șālih government. According to IRIN (2010), revenge killings in the three governorates al-Jawf, Ma'rib, and Shabwah claimed the lives of 4,698 people between 1998 and 2008 . 
al-silbiyyah li-l- urf). ${ }^{20}$ These statistics should be considered with caution, because they cover only a few governorates and because there are no figures on the years preceding unity in 1990, a phase in Yemeni history that was also marked by tribal unrest. ${ }^{21}$ The evidence should nevertheless make it possible to deduce at least two reliable aspects, namely that in some places in rural highland Yemen, cases of blood vengeance seem to be increasing at the expense of diyah solutions, and that the process of blood revenge increasingly disregards the rules of tribal customary law.

Tribal customary law encourages peaceful settlements and discourages revenge solutions. Hence, the causal link between "negative traditions of tribal customary law" and the "degeneration of blood revenge" established by the studies referred to above is not fully convincing; it rather reiterates the aforementioned negative prejudices of urban elites against tribes and tribalism and their perceived "cruelty" and "violence." Rather, the answer to this question should be sought in the recent political history of Yemen. Considering the recent past, and, above all, the relationship between the tribes and the republican state, reveals that the rising number of blood revenge cases and the growing disregard of customary rules governing the process of taking revenge can be interpreted as a consequence of incomplete state formation. The policy of patronage in particular, favored by the republican government at the expense of state and institution building, contributed to the weakening of the implementation of tribal customary law.

In its effort to build a modern state, over the years, the government under 'Alī 'Abdullah Șālih, who ruled Yemen from 1978 (1990) to 2012, received enormous amounts of foreign budgetary and advisory support. Yet the government's efforts in state and institution building and provision of administrative and legal services were focused on the capital, the surrounding areas ( $\operatorname{tawq} \operatorname{San}$ ' $\bar{a}$ ') and a few other revenue-generating and easy-to-govern urban centers such as Ta'iz and its surroundings in Lower Yemen, Aden and the port city of al-Hudaydah. Beyond these areas, the republican government relied on the policy of patronage of the tribal leaders. Patronage of the shaykhs by the rulers - whether Zaydi imams or the Ottomans - has a long tradition in Yemen and was continued largely uninterruptedly by the republic, with the difference that after 1962 the tribal leaders attained far more political power and participation than during the Zaydī imamate, where leadership positions in the government and administration were almost invariably ascribed to the social stratum of the sädah. After the unification of North and South Yemen in 1990, Yemen evolved into a multi-party system with an elected parliament and president, and an independent judiciary only on paper. Power and wealth continued to be produced and transmitted through the highly informal, yet deeply patterned web of tribally and regionally based patronage relationships. ${ }^{22}$

Patronizing the tribal leaders took place at the expense of real state and institution building and had far-reaching consequences in the rural areas of highland Yemen. At this point, we have to understand that the empowerment of tribal leaders in national politics should not be equated with the empowerment of tribalism and the tribes. This apparent contradiction is due, on the one hand, to the concerns of the republican government that the enlarged role given to the shaykhs after 1962 would jeopardize the supremacy and (precarious) power monopoly of the state. For this reason, the government worked

20 This tendency is particularly noticeable in the contributions of the collective volume edited by Mușțafā (2004).

21 On these conflicts that shook large parts of highland Yemen in the 1980s, see 'Abd al-Salām 1988, 91; Dresch 1995, 45-46 and 2000, 180 .

22 On the system of patronage in Yemen, see Phillips 2008; Longley Alley 2010. 
on the weakening of the tribes' strength and the destruction of their unity. Rather, the informal ruling system used by the Șālih regime aimed at fomenting conflict and disorder among the tribes, thereby breaking up larger concentrations of tribal power, and preventing tribal communities from linking up and possibly turning against the government. ${ }^{23}$ In the Weberian tradition, the modern state is seen as an entity that claims the monopoly of the legitimate use of physical force and control of violence within a given territory. In Yemen, the republican government might have held the tools for controlling violence in its hands, but it was not in its interest to employ them. The excessive feuding, which has bedeviled the strong tribes of al-Jawf for decades, is a consequence of the state's policy of divide et impera.

On the other hand, patronage, however much yearned for by individual shaykhs, was a double-edged sword: rather than "nurturing" the tribal system, patronage was meant to drive a wedge between the patronized shaykhs and their tribal home constituencies. For the shaykhs, the elevation and insulation from their tribal communities and their daily affairs was a mixed blessing, as the influx of wealth and the orientation towards the capital weakened their influence among their tribes and undermined their ability to mediate and arbitrate in tribal disputes. By no means did this affect all shaykhs, as many of them remained esteemed leaders closely connected to their tribal home bases, who continued to perform diligently the central tasks of their tribal office: representation and conflict resolution. However, the orientation of many minor and major shaykhs towards national politics and their dissociation from their tribal home bases weakened the tribes' ability to resolve their conflicts according to tribal customary law. We have seen that the process of tribal mediation and arbitration - avoiding and managing blood revenge, in particular - involves a profound knowledge of complex rules and procedures and the diligent and incessant commitment of many persons in different functions, such as mediators, arbitrators, guarantors, solidary groups, and vengeance groups. In the process of tribal conflict resolution, the shaykhs take over a central role as representatives, guarantors, mediators, arbiters, and judges of appeal. The alienation between shaykh and tribe, along with concurrent processes of urbanization, migration, and social change, weakened the customary system of conflict management without offering viable alternatives, because the judicial system of the state remained dysfunctional (al-Zwaini 2012). From the point of view of the state, this, too, was a welcome effect because tribes without strong leaders were weak and fragmented and did not pose much of a threat.

As a result, people began to enforce a kind of "self-help" or freelance revenge that disregarded tribal rules, practices and traditions, and that transformed blood vengeance from an "accepted marginal case" into a "common pathology" ('Umar 2004, 175). In this way, the process of vengeance ran the risk of degenerating into a random process, ungoverned by the tribal rules, procedures, and morals that have always been associated with it. Many contributions in the Yemeni media describe the dire consequences when customary methods of containment and resolution are flouted: cases of disproportionate force, random killings, the targeting of women and children, lootings and destruction (al- 'Asālī 2009; Ghazwān 2010; al-Dawsari 2012). In some areas, the void in tribal conflict resolution caused by the absence of effective tribal leaders, as well as the lack of legal alternatives caused by the dysfunctionality of the judiciary of the state, generated a situation of dilapidation and chronic feuding,

${ }_{23}$ The "politics of permanent crisis" shaped not only state-tribe relations, but also the relationship of the Șalih government with foreign states, see Phillips 2011. 
in which the feuding groups even began to target each other's cattle and sheep. ${ }^{24}$ This feuding situation more closely resembled the seemingly unbalanced outbursts of violence in medieval Europe than the revenge processes governed by tribal customary law. ${ }^{25}$

Since the turn of the millennium, the troubled situation caused by the weakening of tribal conflict management - along with political, sectarian and economic grievances - has been one of the entry gates through which the Hūthī movement has been able to extend and consolidate its influence in many conflict-ridden tribal areas of northernmost Yemen. The Hūthīs are a Zaydī political-religious movement that pursued an agenda of grievances against the Șālih government before they themselves became the dominant power in northern Yemen in 2014. ${ }^{26}$ The eponymous al-Ḥuthī family, whose members are leading the movement, belongs to the social stratum of the sädah. Due to the sādah's traditional function as learned men of Islamic law, sādah affiliated to the Hūthī movement were strategically deployed to act as mediators, negotiators, and arbiters according to Islamic law in tribal conflicts, thus filling the vacuum created by the disinterest of many shaykhs and the dysfunctional judicial system of the state (Brandt 2017a, 143-144).

Today, however, fourteen years after the eruption of the Ḥutthī conflict in 2004, and four years after the beginning of the Saudi-led military intervention in Yemen, the situation is marked by random violence more than ever before. Through the brutality of the war and heterogeneity of the involved warring parties and their numerous, diverging objectives and motivations, as well as the rising phenomenon of warlordism and war profiteering, the situation became a kind of "hybrid" war whose tribal, political, ideological, military, sectarian, and personal elements keep fluctuating. Again, the brutalization of the current war is not caused by tribal norms, but rather by their erosion.

\section{Conclusion}

In rural highland Yemen, the customary practices of blood vengeance, feuding and peacemaking are rooted and bound together in the overarching concept of tribe. And just like the concept of tribe, vengeance and feuding cannot be considered as phenomena isolated from the prevailing socio-political realities. The mutual interplay of ordering and disordering impulses of both tribalism and the state cannot be understood from one direction. Political realities shape the way tribal communities cope (or fail to cope) with conflict, and the undercurrents of tribalism and feuding determine Yemen's complex sociopolitical dynamics and the way they play out in everyday life. This becomes particularly evident in the changes that tribal conflict resolution has undergone in recent decades in Yemen. This chapter argues that the state-sponsored weakening of the rule of tribal customary law and the negative repercussions on customary conflict resolution are a consequence of the state's policy of divide et impera in the tribal areas of Yemen.

Beyond the local focus, the Yemeni example mirrors the general observation that blood vengeance is a polymorphous phenomenon whose ambiguity continues to obstruct the generation of a viable theoretical framework. Whenever we go beyond the lowest common denominator - that is: "killer gets killed" -, we find ourselves confronted with the difficulty that blood revenge and blood feud, albeit

For the Habūr case, see Brandt 2017a, 136.

On the manifold forms of blood vengeance and feud in medieval Europe, see, for example, Roche 2010.

On the history of the Hiuthī conflict, see Brandt 2017a. 
being concepts of practical concerns, are rather difficult to frame theoretically. Today, in the age of migration, urbanization, socio-political change and massive politicization of conflict, the framing and definition of the concept and its theoretical discussion become ever more difficult.

The consideration of blood revenge in Yemen reveals the multi-dimensional, even contradictory, nature of its socio-cultural framework: the tribes. In talking about tribe, vengeance, and feud, we inevitably encounter difficulties and criticism, but there is no better alternative that would not imply a descent into arbitrariness. We always have to take into account that people, their ideas, their customs, their physical, social and political environments interact in dynamic ways, with multi-directional consequences. Given the complexity of human reality that social anthropology sets out to investigate, and, in particular, with investigating tribes and tribalism and their diverse manifestations and customs, we must meet the double challenge of increasing our awareness of socio-cultural and political complexity and closing off a manageable portion for presentation.

\section{References}

'Abd al-Salām, Muhammad. 1988. Al-jumhuriyyah bayn al-salțanah wa l-qabīlah fì al-Yaman al-shamālī [The Republic between Sultanate and Tribe in Northern Yemen]. Cairo: Sharikat al-amal li-1-tibā'ah wa l-nashr wa l-tawzī' .

Abū Ghānim, Faḍl. 1985. Al-bunyah al-qabaliyyha fì l-Yaman bayn al-istimrār wa l-taghayyir [The Tribal Structure between Continuity and Change]. Șan'ā': Dār al-Hikmah al-Yamāniyyah.

Adra, Najwa. 1982. Qabyala: The Tribal Concept in the Central Highlands of the Yemen Arab Republic. Ph.D. thesis, Temple University.

2016. "Tribal Mediation and Empowered Women: Potential Contributions of Heritage to National Development in Yemen.” International Journal of Islamic Architecture 5 (2): 301-337.

Al-Aḥmadī, 'Ādil. 2014. "Al-taḥkīm al-qabalī yu 'akkr al-thawrah wa l-qānūn fî l-yaman” [Tribal arbitration distorts the revolution and the law in Yemen]. Alarabi, 31 March 2014.

al- 'Alīmī, Rashād. 1988. Al-qadā' al-qabilī fì al-mujtama 'al-yamañ̄ [The Tribal Judiciary in the Yemeni Society]. Șan 'à' : Dār al-Wādī li-l-Nashr wa l-Tawzì' .

Almasdar Online. 2017. "Aḥmad 'Alī 'Abdullah Șāliḥ yatawa id bi-l-tha'r li-wālidihi” [Aḥmad 'Alī 'Abdullah Șaâliḥ vows to take revenge for his father]. 5 December 2017, almasdaronline.com/article/95917.

al-Amri, Husayn Abdullah. 1985. The Yemen in the $18^{\text {th }} \& 19^{\text {th }}$ Centuries: A Political \& Intellectual History. London: Ithaca Press.

al- 'Asālī, 'Abd al- 'Azīz. 2009. "La 'nat al-tha'r: al-asbāb, al-natā'ij, al- 'ilāj”" [The curse of vengeance: causes, results, treatment]. Sawtshouraonline.com, 14 April 2009.

Brandt, Marieke. 2016. "Heroic History, Disruptive Genealogy: Al-Hasan al-Hamdānī and the historical formation of the Shākir tribe (Wā’ ilah and Dahm) in al-Jawf, Yemen." Medieval Worlds 3:116-45.

_ 2017a. Tribes and Politics in Yemen: A History of the Houthi Conflict. London and New York: Hurst/Oxford University Press.

_ 2017b. "Delocalization of Fieldwork and (Re)Construction of Place: Doing Ethnography in Wartime Yemen." International Journal of Middle East Studies (IJMES) 49 (3): 506-510.

Black-Michaud, Jacob. 1975. Cohesive Force: Feud in the Mediterranean and the Middle East. Hoboken: Blackwell. Brögger, Jan. 1971. Montevarese. A study of peasant society and culture in Southern Italy. Oslo: Universitetsforlaget.

Bourdieu, Pierre. 1972. Esquisse d'une théorie de la pratique. Précédé de Trois études d'ethnologie kabyle. Geneva: Librairie Droz. 
Boxberger, Linda. 2002. On the Edge of Empire: Hadhramawt, Emigration, and the Indian Ocean, 1880s-1930s. Albany: SUNY.

Caton, Steven. 1987. "Power, Persuasion, and Language: A Critique of the Segmentary Model in the Middle East.", IJMES 19:77-102.

1990. Peaks of Yemen I Summon: Poetry as Cultural Practice in a North Yemeni Tribe. Berkeley: University of California Press.

al-Dawsari, Nadwa. 2012. "Tribal Governance and Stability in Yemen." Carnegie Endowment for International Peace 24, https://carnegieendowment.org/2012/04/24/tribal-governance-and-stability-in-yemen-pub-47838.

Dresch, Paul. 1982. The Northern Tribes of Yemen: Their Organization and their Place in the Yemen Arab Republic. $\mathrm{PhD}$ thesis, St. Catherine's College, University of Oxford.

1986. "The Significance of the Course Events Take in Segmentary Systems.” American Ethnologist 13 (2): 309-324.

— 1987. "Placing the Blame: A Means of Enforcing Obligations in Upper Yemen." Anthropos 82 (4/6): 427-443.

1989. Tribes, Government, and History in Yemen. Oxford: Clarendon Press.

— 1995. "The Tribal Factor in the Yemeni Crisis." In The Yemen War Of 1994: Causes and Consequences, edited by Jamal S. al-Suwaidi, 33-55. Abu Dhabi: The Emirates Center for Strategic Studies and Research.

2000. A History of Modern Yemen. Cambridge: Cambridge University Press.

2006. The Rules of Barat: Tribal Documents from Yemen. Șan' $\bar{a}$ ': CEFAS/DAI.

— 2015. "Written Law as Words To Live By." In Legalism: Rules and Categories, edited by Paul Dresch and Judith Scheele, Oxford: Oxford University Press.

Encyclopedia of Islam $\left(\mathrm{EI}^{2}\right)$. 2000. Tha' $r$, 2 ${ }^{\text {nd }}$ edition, Vol. X: 442-43. Leiden: Brill.

Evans-Pritchard, Edward Evan. 1940. The Nuer: A Description of the Modes of Livelihood and Political Institutions of a Nilotic People. New York and Oxford: Oxford University Press.

Dumouchel, Paul. 2012. "Revenge or Justice? Obama Gets Osama.” Contagion: Journal of Violence, Mimesis, and Culture 19:9--17.

Durkheim, Émile. 1893. De la division du travail social. Paris: Alcan.

al-Fayfī, Aḥmad. 2009. "Inhā al-khilāf bayn qabīlatay Āl Talīd wa Āl Thābit" [Solution of the dispute between Āl Talīd and Āl Thābit]. Alriyadh, 9 December 2009, http://www.alriyadh.com/2005/12/09/article114024.html.

Gellner, Ernest. 1981. Muslim Society. Cambridge: Cambridge University Press.

Ghazwān, Muḥammad Ghālib. 2010. “Al-tha'r raddat tughadhīhā al-sulțah” [Revenge fuelled by the government]. Mareb Press, 8 October 2010, https://marebpress.net/news_details.php?sid=27999.

Girard, René. 1972. La Violence et le Sacré. Paris: Grasset.

Hartley, John G. 1961. The Political Organization of an Arab Tribe of the Hadhramawt. PhD thesis, London School of Economics.

Hénaff, Marcel. 2011. "Terror und Rache: Politische Gewalt, Gegenseitigkeit, Gerechtigkeit - zehn Jahre danach." Lettre International 94:11-21.

Ingrams, Harold. 1942. Arabia and the Isles: Its History and Its People. London: Murray.

IRIN. 2010. Revenge killings keep children out of school. 8 November 2010. http://www.irinnews.org/report/91020/ yemen-revenge-killings-keep-children-out-school.

Jamous, Raymond. 1992. "From the Death of Men to the Peace of God: Violence and Peace-making in the Rif." In Honor and Grace in Anthropology, edited by John G. Peristiany and Julian Alfred Pitt-Rivers, 167-192. Cambridge and New York: Cambridge University Press.

Longley Alley, April. 2010. "The Rules of the Game: Unpacking Patronage Politics in Yemen.” Middle East Journal 64 (3): 385-409.

Mauss, Marcel. 1990 [1925]. The Gift: The Form and Reason for Exchange in Archaic Societies. London: Routledge. 
Middle East Eye. 2018. "Saudi Arabia to pay compensation to Khashoggi family", 6 November 2018. https:// www.middleeasteye.net/news/saudi-arabia-pay-compensation-khashoggi-family-and-fiancee-says-turkishofficial-2016567611.

Muir, Edward. 1993. Mad Blood Stirring: Vendetta \& Factions in Friuli during the Renaissance. Baltimore: Johns Hopkins University Press.

Mușțafă, Nașr Țaha (ed.). 2004. Zāhirat al-tha'r fì l-Yaman [The phenomenon of blood vengeance in Yemen]. Șan'ā': Dār al-Kutub.

National Democratic Institute for International Affairs (NDI). 2007. "Yemen: Tribal Conflict Management Program: Research Report." https://www.ndi.org/sites/default/files/Conflict\%20Management\%20Program\%20 Research\%20Report\%20March\%202007.pdf.

Nu 'mān. Aḥmad Muhammad. 1965. Al-atrā́f al-ma niyyah fì l-Yaman [The involved parties in Yemen], Beirut: Mu'assassat al-Ḍabbān.

Peters, Emrys. 1967. "Some Structural aspects of the feud." Africa XXXVII (3): 261-282.

Phillips, Sarah. 2008. Yemen's Democracy Experiment in Regional Perspective: Patronage and Pluralized Authoritarianism. London: Palgrave.

2011. Yemen and the Politics of Permanent Crisis. London: Routledge.

al-Qu 'ayțī, 'Abd al- 'Azīz. 2009. Ihlāl al-salām fì Hadramawt: dirāsah tārīkhiyyah li-tajribat Hadramawt fì al-qadà' 'alā al-tha' $r$ al-qabalī, 1933-1953 [Establishing peace in Hadramawt: a study of Haḍramawt's experience in eliminating tribal feud, 1933-1953]. London: Arabian Publishing Ltd.

Rathjens, Carl. 1951. "Taghut gegen scheri’ah.” Jahrbuch des Linden-Museums, Stuttgart: Linden-Museum.

Roche, Thomas. 2010. "The Way Vengeance Comes: Rancorous Deeds and Words in the World of Orderic Vitalis." In Vengeance in the Middle Ages: Emotion, Religion and Feud, edited by Paul R. Hyams and Susanna A. Throop, 115-136. Aldershot: Ashgate.

Rossi, Ettore. 1948. "Il diritto consetudinario delle tribù arabe del Yemen." Rivista degli Studi Orientali 23:1-36.

Sahlins, Marshall. 1965. "On the Sociology of Primitive Exchange." In The relevance of models for social anthropology, edited by M. Banton, 139-236. London: Tavistock.

Șayyād, Muḥammad b. 'Alī. 2014. Wathīqat al-qawāid: al-marja iyyah al-urfiyyah li-kāfat al-qabā'il alyamaniyyah [The document of the rules: The customary reference of all tribes of Yemen], San 'à': Maktabat Khālid b. al-Walīè.

Schacht, Joseph. 1993. An Introduction to Islamic Law. Oxford: Oxford University Press.

Serjeant, R. B. 1983. "Șan 'à', the 'Protected' Hijrah.” In Șan 'ā': An Arabian Islamic City, edited by R. B. Serjeant and Ronald Lewcock, 39-43. London: World of Islam Festival Trust.

Tyan, Emile. 1963. "Diya." in Encyclopaedia of Islam, Second Edition, edited by P. Bearman, Th. Bianquis, C. E. Bosworth, E. van Donzel, 350-352. Leiden: Brill.

'Umar, 'Alī Ahmad. 2004. Mawqi al-tha'r fì manzūmat al-qiyam al-ijtimā'iyyah [The role of revenge in the social value system]. In Z̄ähirat al-tha'r fĩ l-Yaman [The phenomenon of blood vengeance in Yemen], edited by Nașr Țaha Muștafāā, 167-89. Șan' 'à': Dār al-Kutub.

Weber, Max. 1922. Wirtschaft und Gesellschaft. Tübingen: Mohr.

Weir, Shelagh. 2007. A Tribal Order: Politics and Law in the Mountains of Yemen. Austin: University of Texas Press.

Wilson, Stephen. 1988. Feuding, conflict and banditry in nineteenth-century Corsica. Cambridge: Cambridge University Press.

al-Zwaini, Layla. 2012. "The rule of law in Yemen: Prospects and challenges." HiiL Rule of Law Quick Scan Series Yemen. 


\title{
QABİLAH, JIRBAH AND TANMIYAH: TRIBES AND AGRICULTURE IN THE NORTHERN HIGHLANDS OF YEMEN
}

\author{
Daniel Martin Varisco
}

The stereotypical image of an Arab tribesman is a nomadic Bedouin mounted on a camel in the desert. To be tribal in Yemen, however, is to be sedentary and most often to engage in agriculture. This is especially the case in the highlands with its fertile valleys that have been cultivated for several millennia since the ancient kingdoms of South Arabia. The civil society throughout the Islamic era in the highlands has been tribal, especially in the northern area where the Zaydī imamate was established during the late $9^{\text {th }}$ century. Throughout Yemen, agricultural activities were primarily governed by tribal customary law ('urf), usually in harmony with Islamic legal principles. Irrigation from springs, wādī flood flow, and wells was shared according to customary procedures, as was the ownership and sale of land. Local markets, where agricultural produce was traded, were also subject to customary tribal law. This article discusses the historic role of agriculture in relation to tribal identity and tribal customary law against the backdrop of changes brought about through agricultural development and the current insecurity and open warfare. This includes the decline in water tables, land grabbing, the cash cropping of $q \bar{a} t$, and reliance on imported foodstuffs. Although agriculture has declined in recent years, there is potential for sustainable development of Yemen's agriculture into the future.

\section{Introduction}

During much of the Islamic era, Yemen served as the breadbasket of the Arabian Peninsula, the vast majority of which is arid and inhospitable to sustainable agriculture. With its natural water sources of sufficient rainfall in the southern highlands, major wādīs toward the coasts, highland springs, and available ground water, farming became the primary economic livelihood in Yemen well before the Islamic Era. The ingenuity in creating massive and small-scale irrigation systems and turning mountain slopes into terraced gardens is well documented and still evident as one travels through the country. By the $10^{\text {th }}$ century CE, Yemen had become an area rich in crops (Varisco 2009). During the Rasulid Era $\left(13^{\text {th }}-15^{\text {th }}\right.$ centuries CE) a wide variety of crops were cultivated, providing the state with food for its people and a significant source of taxes (Varisco 1994b). Food production was generally adequate for the local population and some foods were exported, including to Mecca. In this sense, the history of Yemen cannot be written without major attention to its agriculture over the centuries.

The focus of this study is on the role of agriculture in the northern highlands, including the regions of Șan' $\bar{a}$ ', Hajjah, Șa 'dah and the Jawf. Unlike the southern highlands, rainfall was limited, forcing a need to develop innovative techniques in dry farming and water runoff harvesting and limiting the range of crops grown. Those areas with springs and groundwater accessible through wells allowed for more stable cultivation. The most difficult ecological zone was the Jawf, the region that borders the famed "Empty Quarter" of the Arabian desert. The population in the north was overwhelmingly rural, 
tribally organized and self-sufficient. There was never a strong central state in control, even after the revolution that toppled the Zaydī imamate in 1962. Apart from the construction of the new Ma'rib dam, inaugurated in 1986, the northern governorates of Yemen did not receive as much development aid or investment in agriculture as the southern highlands and coastal Tihāmah.

\section{Qabīlah: The Idea of Tribe in the Northern Highlands}

In cultural terms, Yemen has a resilient tribal tradition, primarily rural, that persists into the present. Unfortunately, there is often confusion as to what it means to be tribal in Yemen. The population in most of Yemen has been sedentary for centuries, if not millennia. There are a few pockets of Bedouin nomads on the fringe, but to be a tribesman in Yemen has almost always been to belong to a settled farming community. This has implications on the role of customary law, which in most of the highlands is more attuned to the security needs of agriculturalists than pastoralists, to protection of land and markets rather than safekeeping of domestic animals. Tribal polity is stronger in the north than southern Yemen, which in places has more of a patron/client relationship, and the Tihāmah coastal zone, which has experienced the most foreign contact historically. Unlike in most other parts of the Middle East, tribalism in Yemen has never been subdued by the state, despite attempts by former president 'Alī 'Abd Allāh Șālih to forge a party-based nationalism. Events since the Arab Spring and subsequent civil war resulting from the Saudi-led coalition bombing campaign have in some ways bolstered tribal sensitivities at the local level, but the prolonged insecurity and politicized polarization present a major challenge to the future of tribe-state relations.

The nature of tribalism varies throughout Yemen, although there is a long, shared history in genealogical terms. Yemen was the ancestral home of Qahțān, the founder of the "Southern Arabs," which figure in tribal identity throughout the Arab Peninsula and much of the Arab world. It is important to note that tribal genealogy in Yemen, as elsewhere in the Arab world, is a contested issue. The Yemeni savant al-Hamdān 1 (1940), writing in the $10^{\text {th }}$ century, was critical of Arab authors who made errors regarding early Yemeni genealogy. As is clear from the observations of multiple anthropologists working in Yemen, most ordinary tribesmen have a limited knowledge of their direct ancestors (Varisco 2017). This is due in part to the fact that written genealogies of tribesmen are rare, but also because the "tribe" in Yemen has more of a geographical locus than a kinship focus. Some tribal names extend back more than two millennia in the same region (Robin 1978).

There are several terms used in the literature for tribal groups and divisions, but it is universal to refer to the individual male as a qabìli and a female as bint al-qabìlì. Despite limitations as a political or social category, there is no substitute for translating Arabic qabīlah into tribe (English), tribù (Italian), tribu (French and Spanish), or Stamm (German) and qabīli as tribesman. The plural form qabā'il is even referenced in the Quran (Șürat al-Hujurāt 49:13). In Arabic lexicons qabïlah is defined as those who descend from a single father or ancestor (banu $a b$ wăhid). It is interesting to note that the verbal form $(q-b-l)$ has a wide range of meanings, including to come face to face or in contact with, to receive hospitably, consent, power, and guarantee: all of these could be applied to Arab tribes. When a tribesman in Yemen is asked for his tribe, he invariably refers to one of the ancestral tribal names or even the tribal confederations of Bakīl, Ḥāshid and Khawlān ibn 'Āmir which comprise most of the northern tribes. ${ }^{1}$

For details on the tribes near Șa dah, see Brandt 2017; Gingrich 1994; and Weir 2007. For tribes in the highlands of Yemen as a whole, see Dresch 1989, who also discusses the information from tribes in the work of al-Hamdānī. A master list of Yemeni tribes can be found in the geographical lexicon of al-Maqhafĩ (2002). 
At the lower levels, the most important reference is to the extended lineage of 5-7 generations, i.e., those in the memory of someone living. Since most tribes are sedentary, there is less need for the type of fusion and fission that has been noted for nomadic Bedouin (Peters 1960).

In a political sense, belonging to a tribe provides a community of support as well as a mechanism for maintaining allegiance. At the local level, the lineage may define a marriage pool, work parties and either a war or defense grouping. The basic principle of organization is based on consent rather than dictation. In theory the shaykh of a tribal segment is a first among equals, although there are also shaykhly lineages, which are more common when tribesmen are sedentary (Dresch 1989, 89). In his work among the Banī Hushaysh, Walter Dostal noted that the qualities of a tribal shaykh should be a good character, experience, a sense of justice, and the ability to negotiate (Dostal 1974, 8). Customary law, which in Yemen was at times written down, applies to all sorts of misbehavior and criminal acts, with shame and the threat of expulsion from a tribe working to mitigate disputes. In the northern area of Yemen, tribes were traditionally responsible for protecting the Zaydī sādah - who usually lived in an area known as a hijrah -, Jews, and those who were too weak to defend themselves.

To situate the role of the tribes in northern Yemen, it is important to place them within the total social structure. An elaborate and influential scheme of the highland Yemeni social structure of the past was presented by Eduard Glaser (1885b, 202), who traveled extensively in the Zaydī area over a century ago. Although he was not a trained anthropologist, he recognized a distinction between rural and urban areas and proposed three descriptive, hierarchical models: rural, urban, and generalized. While his rationale for distinguishing categories is not always clear, he presents the basic model of a social structure with the sādah (sg. sayyid) descendants of the Prophet Muhammad at the top, tribes in the middle and a range of client groups, freed slaves and Jews at the bottom. ${ }^{2}$ The sayyid was granted a higher status, on religious grounds, than the tribesman, although this did not mean that tribesmen considered themselves inferior. ${ }^{3}$ In the Zaydi areas the sayyid had a higher status than religious scholars of tribal origin, who are called $q u d \bar{a}^{\prime}$ ' (literally, "judges") in Yemen. Client groups performed ritual and menial tasks, such as circumcision, butchering animals and growing vegetables. For Glaser, freed slaves were ranked above the akhdām, a group of poor blacks who performed menial and degrading tasks. The Jews were held in least esteem, even though they might be wealthy merchants.

The general ordering of social categories is not something that Glaser or later anthropologists started. It reflects an emic distinction with a ring of truth, but also one that varied between regions and even within the northern parts of Yemen. Status was clearly important in arranging the group, often based on perceived genealogical ranking; there were urban/rural distinctions and no group existed in isolation from the others. Not every segment of society has been committed equally to a particular emic model of status. Claims of a specific descent often serve to cover up inequality for economic or political opportunities. Thus, no single scheme of the social structure is valid perpetually, nor can it be assumed

2 In al-Ahjur, northwest of Șan' $\bar{a}$ ', where I conducted my fieldwork, a threefold distinction was made between $s \bar{a} d a h$, $q a b \bar{a} ' i l$ and banū khüms, the last covering several client groups that performed circumcisions, played music, grew vegetables and shouted praise (Varisco 1982a, 154-179). See Dresch 1989, 118-123 and Rathjens 1951:177-179 for a discussion of the relation of weak client groups to tribes. Tobi 1999, 142-156, examines the relationship between Yemeni Jews, tribes and the Zaydi elite in the northern highlands.

3 The social hierarchy does not necessarily reflect the socioeconomic aspects of individuals and there were indigent and politically marginal members of the sādah and quạa ', as noted by Haykel 2002, 206. 
to be accepted by all involved. A model of social structure is simply a convenient way of categorizing; it is most often used to justify the power and prestige of those groups at the top end of a hierarchy or those who benefit the most.

Another way of looking at tribalism is to focus on core tribal values, a notion called qabyalah in Yemen's North. In her extensive discussion of Yemeni qabyalah, Najwa Adra $(1997,87)$ notes that it

refers to proper behavior according to accepted standards and to a tribal esthetic. Honorable behavior, especially that which involves interaction with other families or groups, or contexts in which mutual responsibilities are called upon, where the welfare of the group is involved and where presentation of self is important, is described as qabyalah... For the tribal population of the northern highlands qabyalah represents the good, the true and the beautiful.

Central to the concept is the sense of honor, at least within the group. These values support group cohesion and allow for maintaining a civil society in the absence of a central government. The principles of qabyalah, more general than specific aspects of tribal law ('urf), were expected of tribesmen and admired in those from other social categories.

\section{Jirbah: Traditional Agriculture before Development Impact}

The primary economic activity of northern Yemeni tribesmen has been agriculture, notably the production of cereal grains and a few legumes on an agricultural field (jirbah). The vast system of highland terraces, still visible although in decline, was developed and maintained over centuries. Unlike the coastal region, where wādī flow from the highland escarpment allows for flood-based (sayl) irrigation, the majority of northern highland agriculture was based on dry farming, water runoff harvesting, limited local wādī flow and small-scale spring irrigation (ghayl). Until the 1970s, when pumpwells began to proliferate in the highland valleys, wells were primarily used for small garden plots, especially near major towns (Gingrich and Heiss 1986, 27). The major obstacle to cultivation was the relatively low annual rainfall, which could vary widely from year to year. Total annual rainfall in the Sa 'dah basin for 1983-1991 averaged only $129 \mathrm{~mm}$ (Lichtenthäler 2000, 143). Dry farming was possible due to the ingenuity of farmers in choosing drought-resistant crops, like sorghum and barley, and increasing the moisture in fields through water runoff harvesting. ${ }^{4}$ The goal of such a source is to channel slope flow by arranging a line of rocks or small channels to direct it to cultivable fields. An added advantage is that the runoff often carries with it organic content that increases the soil fertility. This must be done in such a way that the field is not flooded to the extent of erosion, since the farmer will not be present when the rain falls. Runoff rights in the Șa dah region became even more important as the groundwater declined through the unregulated sinking of tubewells (Lichtenthäler 2016, 26). There are also a few underground gravity-flow channels in parts of Yemen similar to the anat and falaj systems elsewhere in the Middle East. ${ }^{5}$

$4 \quad$ For detailed analysis of Yemen's runoff harvesting, see Eger 1987, 1984; and Hovden 2006. Runoff harvesting in al-Ahjur is discussed in Varisco 1982a, 209-212.

5 I observed such an underground channel from a spring cistern in al-Ahjur, although the local inhabitants had no idea how old it was. Similar systems in the Harāz area are discussed by Vogel (1988). 
The traditional agricultural methods changed little over the centuries until after the civil war in the north, with the introduction of modern pumpwells and mechanization. While cultivation on the steep terraces still required animal draft power and hand tillage, the proliferation of wells opened up field systems in the central plains where tractors could be used. One of the reasons for the long-term continuity of the traditional agricultural system was that it was well adapted to the local environment. Field systems could be created and maintained by the household, in which men, women, and children were actively involved in cultivation and the care of family livestock. The tools were usually made locally, using wood from regional trees for plow beams, yokes and handles (Varisco 1982b). For hand tillage the most important tool was a mafras, a type of mattock with a narrow adze-shaped blade on one side. Those with access to a smith would have iron plowshares, but pointed wooden shares were also used. Draft animals on large fields consisted of bulls and at times camels, but for steep terrace systems, donkeys were more common. Local pasture and fodder from sorghum stalks and leaves was generally sufficient for these animals, but some lucerne ( $q a d b)$ was grown where there was perennial flow from springs or wells.

The dominant crop in the northern highlands, given the subsistence economy of the past, has been sorghum (dhurah), a versatile cereal grain which can be cultivated at up to 3,000 meters elevation. ${ }^{6} \mathrm{~A}$ Yemeni proverb states that sorghum is as important for food as a woman is to running the household (al-bayt al-mara'ah wa-al-habb al-dhurah) (al-Akwa' 1984, I, 304). ${ }^{7}$ Sorghum adapts well to drought and is able to survive on as little as $250 \mathrm{~mm}$ per year. The sorghum plant consists of a central stalk, leaves and a head or panicle of grain near the top. In the highlands the head is densely packed with seed kernels. The basic distinction of the variety is by color (white, yellow, red), but there are many names for local varieties. Sorghum provided for a variety of uses. The nutritious grain, threshed with the use of a flail on a stone floor, could be ground into flour for bread or for a local porridge known as 'așid. The leaves, often stripped before the harvest of the heads, along with the upper part of the stalk provided fodder for animals. The bottom part of the stalk, when dried, serves as firewood for the tannür oven. Sorghum grown on rainfed land may be less than a meter high and has less fodder value than that grown with irrigation.

The two other important cereal grains in northern Yemen have been wheat (burr) and barley (sha 'ir), which are limited to higher elevations above 1,000 m. In the past emmer wheat (Triticum dicoccum), known locally as 'alas, was cultivated. Emmer is a hulled variety with two or three grains in each envelope. It must be crushed manually by a mill rather than threshed by draft animals. While emmer required more work, there is almost universal agreement in Yemen that it made the best bread (alWāsi' 1 1948:138). Barley is more drought resistant and tolerant of soil salinity than wheat, but not as able to withstand the cold as winter wheat varieties. A huskless barley variety known as sult was also grown. Maize is a relatively recent addition to Yemen, but gained in popularity on irrigated land in the highlands after the 1960s civil war.

\footnotetext{
${ }_{6} \quad$ Kopp 1981 provides estimates for the production of sorghum in all regions of Yemen. For details on the history of sorghum production in Yemen, see Varisco 1985. It is important to note that British scholars often referred to sorghum as "millet," but this should not be confused with the millets (Pennisetum and Panicum) in Yemen.

7 It should be noted that rural tribal women enjoyed much greater freedom than their urban sisters (Rathjens 1951, 184). In tribal customary law, offenses against women were severely punished (Rossi 1948,24).
} 
Apart from the cereal grains, other traditional crops included legumes, such as lentils ('adas), broad beans (bāqilla $\left.{ }^{\prime}\right)$ and cowpeas (dijr); the latter two were often intercropped with sorghum on irrigated land. The northern part of Yemen in the Șan ' $\bar{a}$ ' and Șa dah basins was especially famous for its varieties of grapes in areas above $800 \mathrm{~m}$ (Kopp 1981, 99). Coffee was grown on the Western Escarpment between 1,000 and 2,000 m, where the ascending mists provided a perfect location. Qāt (Catha edulis) production was limited until the 1970 s, when its production and use greatly increased. ${ }^{8}$ Several kinds of fruit and nut trees were also cultivated, but only in limited quantities. Lucerne ( $q a d b)$ was cultivated where there was perennial water. Only a few vegetables were cultivated, mainly in gardens irrigated from hand-dug wells. Tribesmen usually considered cultivation of vegetables as having less honor. ${ }^{9}$ In the northern highlands these vegetable farmers include a servile group known as qashshām, ${ }^{10}$ in reference to someone who grows and sells qushsmī, the Yemeni term for a long, white radish also known as fijl. In the valley of al-Ahjur the qashshām also cultivate the leek (karrāth or qushmi akhdar) and the scallion (bașal). It is wrong to assume that the status of the qashsham is related specifically to the vegetables he grows. Tribal farmers grow radishes, leeks, and scallions for their own household consumption. The difference is that the qashsham grows and sells vegetables as a profession; he continually deals with the market. Nor can the vegetables he grows be stored from year to year, as cereal crops and legumes can. It is this association with mundane concerns in commerce that has been considered beneath the dignity of a tribesman. Perhaps another reason for the low status of the qashsham was the association of vegetable farming with the Yemeni Jews, who also cultivated these vegetables. The qashshäm generally lived near or in a market town. In the past he did not own land, but was a share-cropper.

\section{'Urf and Shar'̄'ah: Tribal Customary and Islamic Law}

The Islamic legal tradition ( sharì $^{\prime} a h$ ), including the formal texts of fiqh, provide only a few rules or principles for agricultural production and irrigation, building on relevant traditions from the Prophet Muhammad. In Yemen, as in many parts of the Islamic world, there is a balance between formal Islamic law and customary law and practice, usually known as 'urf. ${ }^{11}$ While there have been elements of tribal customary law that have been criticized by Islamic scholars, both Zaydī and Shāfi ' $\overline{1}$, in the past, these related to issues like the denial of inheritance rights to women and resolution of blood feuds rather than how farmers practice agriculture and allocate irrigation water. ${ }^{12}$ Yemeni tribesmen vigorously reject the idea that 'urf goes against shari' ah (Weir 2007, 148). It was often the case that customary law was preferable over Islamic law because tribal decisions tended to focus on compromise and healing a social breach; decisions were usually made sooner with less expense than a formal Islamic court (Meissner 1986, 271).

8 For the role of $q \bar{a} t$ in the northern highlands, see Shelagh Weir (1985). The debate over the use of qāt in Yemen is discussed in Varisco (2012).

9 It is reported that during the 1970s in al-Maḥābishah, near Hajjah, tribesmen did not sell their own produce in the market, nor would they sell anything sold by weight (Meissner 1986, 197-198).

10 The low status of the qashsham is reflected in a Yemeni proverb recorded by Goitein 1934, 44: "The daughter of a qashshām and I paid the price for an Imam's daughter (bint al-qashshām ushrat shart bint al-imām)."

11 For the relationship between 'urf and sharī'ah in Yemen, see Donaldson 2000, 45-51; Dresch 2006; 1989,184-188, 229; Maktari 197); Rathjens 1951; Rossi 1948 and Weir 2007, 143-225.

12 Such violations of Islamic law were referred to as țăghūt; see Rossi 1948, 9-18 for an extended discussion of this issue in Yemen. 
Customary practices from the very beginning of Islam are relevant for understanding irrigation in an Islamic context. There are several major hadìth sources providing the overall principles; these were clearly based on customary practices at the formation of Islam (Varisco 1982a, 229-244). Muhammad said that "Muslims share in three things: water, pasture, and fire" (al-Muslimūn shurakā' fì thaläth al$m \bar{a}$ ' al-kala ' wa al-nār). This was considered an inalienable right, although there was a hierarchy of needs, starting with water for drinking, then for watering animals, ablutions, and irrigation. Muhammad also noted that whoever held back surplus water would have that amount of mercy withheld from him on the Day of Judgement. In this sense, water is an ownerless resource (res nullius), except for water in a given container or removed from a well on the land a man owns. The point is that water is a shared resource with concomitant obligations, a contractual agreement rather than ownership per se.

It is also important to recognize that access to water cannot be separated from the overall process of resource allocation, including land. In general, water rights are attached to land rights. Islamic jurists have usually argued that a water share (shirb) cannot be sold separately from the land it is meant to irrigate, nor can it be inherited separately from land (Abū Yūsuf 1985, 55). In Yemen it has often been possible to sell or rent a specific time share. The majority of cultivable land in northern Yemen is privately owned (milk), usually verified by documents, although some endowment (waqf) land is leased. Communal land is for pasture rather than agriculture. It was possible to obtain unowned land through a process known as ihyāt al-mawät (the revival of wasteland). In the Zaydī highlands this is accomplished by the following: plowing (harth); planting or sowing (zar); cutting down trees (qat ${ }^{\circ}$ al-ashjār); leveling the land (taswiyyat al-ard̦); building a wall or bounding a field (ittikhādh a 'rām aw sūr 'alayha a); digging a trench (khandaq); or placing markers on the borders of a plot (darb a ' lām fi jawānibhāh tumayyizhāh 'an ghayrihā) (al-Samāwī 1974, 214). This became a development problem in the Șa dah region, as noted by Lichtenthäler $(2016,27)$, where most of the land was not cultivated and not owned.

A well-known Islamic legal point, also reflected in customary law, is the right of pre-emption (shuf'ah). The Zaydī jurist Ibn Miftāh (1357/1938, III, 206) defined shuf'ah as the pre-eminent right of a shareholder in the purchase of a property (al-haqq al-sābiq li-milk al-mushtarā li-l-sharīk). Under Zaydī law there are four cases in which the right of shuf'ah is said to apply (al-Murtaḍa 1975, V, 6):

1. joint ownership (khaltah);

2. partnership in water allocation (shirkah fi shirb);

3. partnership in a road or access route (shirkah fi tarīq);

4. adjacent neighbors (jiwār al-mulāṣiq).

The purpose of this doctrine is to protect the rights of shareholders who entered into a contractual agreement in relation to shared property, such as a spring, well, or qanat. There is a recognition that the right to a share of water involves an investment in a distribution network over land to exploit water for irrigation. In the customary law of the Banī Hushaysh this right is known as juwārah, in which land for sale must first be offered to a fellow tribesman (Dostal 1974, 3; see also Dresch 1989, 81 and Meissner 1986, 259). Similarly, if a tribesman is in debt to someone in another tribe, the creditor only has a limited right to use his land and cannot take it over (Kopp 1981, 136). ${ }^{13}$

13 Shuf'ah in Wādī Zahr was restricted to joint ownership after the 1962 revolution, according to Mundy 1979, 183 , note 10. 
Since the Muslim community shares the resource water, there must be some way of providing fair access to that resource. This is covered by the idea of a harim, a type of buffer zone around a water source. The term harim literally refers to something which is inviolable; thus, the idea that it is forbidden to exploit this land in any way that limits access for legitimate purposes. Although the land of the harim may be owned, the owner is not at liberty to do with it as he pleases. The physical extent of a harim varies from source to source and school to school. The Prophet Muhammad is reported to have said that the harim of a spring ('ayn) should be 500 dhira ' ' or about 325 meters on all sides (Abū Yüsuf 1885, 57). This refers to space within which it is forbidden to look for new water and does not mean that the land must be left vacant. In Zaydī Yemen, the harìm of a well on open land was usually 60 dhiră ' 39 meters) if for irrigation or 40 dhira ${ }^{\prime}$ ( 26 meters) if it is used for pasture and flocks. These distances were suggested when all wells were hand dug and are obviously insufficient with the appearance of tubewells which can mine much deeper aquifers.

Another legal issue relating to agriculture is the need for an agricultural contract (Donaldson 2000). As defined by the Zaydī jurist al-Samāwī $(1974,209)$, the contract (muzāra 'ah) is for the rental of land in which the landlord receives a fixed share of what is grown on the land and the tenant receives a fixed share of what is grown according to a mutual agreement. The land can also be leased for a designated sum of money, in which the tenant keeps all that he produces. The legal texts usually leave the determination of the amount of each share up to the parties involved. However, Muhammad is quoted as forbidding an agricultural contract in which the tenant only receives a third or fourth (al-Sayāghī 1968, III, 650). Such a contract is only permitted if it is a special case of long-term arrangement (Zayd ibn 'Alī 1966, 284). The rental agreement must be free of risk (bi-kull shay' mimma laysa gharar), according to al-Sayāghī. If a tenant is bound to pay off two-thirds of his crop, and it is a poor crop, he may not have enough for his own family's needs. In practice, the specific shares agreed upon in the contract will vary depending on the nature of the crop, land, region, and the simple law of supply and demand.

Given the importance of both cultivable land and water for agriculture, it is not surprising that customary law provided mechanisms for the mitigation and resolution of disputes. A study at Șan' $\bar{a}$ ' University concluded that $70-80 \%$ of conflicts in rural Yemen related to water (Giesecke 2012, 2). ${ }^{14}$ A perennial problem when water is shared along a watercourse is the proverbial upstream/downstream conflict. In a dispute over the use of flood flow to irrigate date palms, the Prophet Muhammad ruled that the higher fields should be watered before the lower in a gravity-flow system (al-Māwardī 1960, 180). This principle is often followed in Yemen, especially when there is sufficient water to share. As noted by Lichtenthäler $(2000,145)$ in the Șa dah region, for local narrow wādīs where it was difficult to expand the land area, the water demand for the flow was limited and thus there was no hindrance to downstream use of the flow. There are exceptions along the major wādī systems in the Tihāmah, where historical precedence can override location. Similarly, this rule does not apply when water is extracted from a stationary source, like a cistern or spring in which shares are designated by a certain time period or an amount of flow to a specific set of fields.

14 This figure appears to be exaggerated, as cases of theft are also common; see Weir 2007, 195-206. 
Tanmiyah: Agricultural Development and Change

During the Mutawakkilite Kingdom of Yemen under the imams Yahyā and Aḥmad, there was virtually no development of agriculture in the northern highlands (Varisco 2018). The civil war, which lasted from 1962 to 1969, further prevented development. In the early 1970s UNDP created the Tihāmah Development Authority (TDA) and the Southern Uplands Rural Development Program (SURDUP) to coordinate agricultural and infrastructure development due to the weakness of the central government ministries. The Northern Regional Agricultural Development Project, established later, provided only minimal support to farmers north of Șan' $\bar{a}$ ', with hardly any near the Șa 'dah region. Strengthened by support from USAID in the 1980s, the Ministry of Agriculture gradually increased its extension services, but the most effective development came from specific bilateral projects, such as the Yemeni German Plant Protection Project based in Șan'ā', a German-funded agricultural station in al-Bawn north of Șan ' $\bar{a}$ ' and the Dutch Rangeland Project in Dhamār.

While multiple foreign experts descended on Yemen to advise on agricultural development, little progress was made. In part this was due to the corruption of officials in government circles, but also to consultant recommendations that often failed to take into consideration the specific social and economic context of Yemen. For example, in the late 1970s the University of Arizona carried out a sorghum improvement project for USAID, which turned out to be mainly an opportunity to expand their seed bank with no practical results for Yemeni production of sorghum. In the mid-1980s an economist visiting Șan' $\bar{a}$ ' from Washington suggested that Yemen stop growing sorghum, still its main crop, without realizing that, in addition to its subsistence value for households, the fodder value made it at times a cash crop. In their brief roadside perspectives, foreign consultants often marveled at the ingenuity of the terrace system, but were unable to see the value of indigenous practices or recognize the important role that women played in the agricultural system. It was assumed that Yemenis were still quite "primitive" and needed to adopt Western modes of production. As a result, "modernizing" Yemeni agriculture was often little more than importing expensive machinery that could not be maintained, pesticides, seeds and fertilizers (Morris 1991; Varisco 1994a).

The most significant change in all of North Yemen after the civil war was the rapid and unregulated proliferation of tubewells. The amount of land irrigated by wells expanded from $3 \%$ of the total cultivated area of the Yemen Arab Republic in 1973 to 37\% of the unified Republic of Yemen in 2003, with a major decline in dry farming from $84 \%$ to $45 \%$. It is estimated that some 800 drilling rigs operated in Yemen by 2000 and $99 \%$ of all water extracted from wells was unlicensed (Giesecke 2012, 3). In 2005 there were as many as 55,000 active wells in Yemen, the vast majority tubewells. By 2014 it is estimated that there were 100,000 operating farm wells, irrigating $40 \%$ of the country's cultivated area (Ward 2014, 91). As has been pointed out for years, Yemen is literally running out of water as it consumes more than the annual recharge. In the Șan' $\bar{a}$ ' basin it is estimated that by 2007 abstraction exceeded recharge by five times (al-Ameri 2011, 21). Adding to the water crisis, it is estimated that the overall efficiency of surface irrigation is only $30-40 \%$ and a mere $4 \%$ of the total irrigated area $(25,000$ ha or 344,691 ha in 2005) applied improved systems of pipe and sprinklers (al-Asbahi 2005, 3).

In the delicately balanced terrace systems in Yemen, erosion is an ever-present danger. If fields near the top of a terrace sequence are not maintained, there can be a domino effect with collapsed walls and migration of soil below. There has been extensive erosion of highland terraces, exacerbated during the civil war and the subsequent out-migration of many Yemeni tribesmen for work abroad in the 1970s and 1980s (Hovden 2006, 49). To some extent, maintenance of the terraces was left to women, but the level 
of out-migration for work led to the widespread abandonment of more marginal terraces (Adra 2013). Another cause of neglect of rainfed terraces has been the switch to newly cultivated land in the central plains due to the ability to pump water from tubewells. Socioeconomic change is also a factor, as the previous tradition of young men continuing in the agricultural work of their fathers and grandfathers has changed with other forms of making a living or migration to urban areas.

Sharecropping is still widespread in Yemen, although the relative loss of manpower for traditional agriculture has had an impact on sharecropping contracts. In 1978, in the village of al- 'Urrah in Wādī al-Ahjur, the rental fee on irrigated land was a quarter of the crop for sorghum (dhurah), maize (rümī), or wheat (burr). The share for growing barley (sha ${ }^{i} r$ ) was only an eighth on irrigated land. Land cultivated with a cash crop, such as coffee or $q \bar{a} t$, went for a third of the harvest. Residents noted the rental fee for most crops was a third in the days of the imams before the 1962 revolution. This indicates that they were better off, in terms of the contracts, than they were before the revolution with major changes in the economy.

Crop choice has also changed in major ways since the formation of the Yemen Arab Republic. The most important example is production of $q \bar{a} t$ trees, increasing from 8,000 ha in 1970 to 103,000 ha in 2000. The demand for $q \bar{a} t$ leaves, a stimulant that has been used in Yemen for five centuries, rose with the influx of cash remittances into the rural sector and expanded or new cash-producing livelihoods in urban areas. It is estimated that as much as $40 \%$ of Yemen's irrigation water, mainly from pumpwells, is devoted to $q \bar{a} t$. Growing $q \bar{a} t$ in new areas was facilitated by expansion of the road network in Yemen, since the leaves must be marketed fresh. It is often assumed that the increase in $q \bar{a} t$ trees was at the expense of coffee, for which Yemen has long been famous. ${ }^{15}$ Coffee and $q \bar{a} t$ arrived in Yemen about the same time via a Șūfi network in the $15^{\text {th }}$ century (Varisco 2012, 71). While the coffee trade from Yemen's port of Mocha was once the major source, it was long ago eclipsed by coffee production worldwide. It is obvious that some farmers growing qāt could cultivate coffee, but the decline in Yemeni coffee has more to do with market forces, given the high cost per kilogram of Yemeni beans. It is also important to note that $q \bar{a} t$ can be grown in a wider variety of ecozones than coffee, which does best on the slopes of the Western Escarpment where there is mist.

North Yemen before the 1962 revolution was generally self-sufficient in food production. There was even limited export to nearby Saudi Arabia. However, the major increase in population and decline in local agriculture have today made Yemen dependent on food imports. It is estimated by the United Nations that Yemen's dependence on food imports is $80-90 \%$, a drastic situation exacerbated by the recent humanitarian crisis in which food and medical supplies have barely been allowed into areas controlled by the Hūthīs. With the decline in rainfed production, there is less cultivation of wheat and barley. In the 1960s, the United States, in their "Food for Peace" program, shipped white flour to Yemen. ${ }^{16}$ Although not as nutritious as the local varieties of wheat, the subsequent import of cheap

15 By 1983 in the Republic of Yemen the cultivated area in the northern governorates of Hajjah, al-Jawf, al-Mahwīt, Ma'rib, Șa 'dah, and Șan ' $\bar{a}$ ' for coffee was 14,082 ha, while there were 35,070 ha for qāt (YAR 1983). Before the 1960s there was virtually no cultivation of $q \bar{a} t$ in the Șa dah basin, although there was in the mountain area of Rāzih to the west (Lichtenthäler 2016, 120).

16 In al-Ahjur during the late 1970s imported wheat, whether in reference to seed or flour, was locally known as kanada or kanadī. This is not, in fact, an Arabic term, but actually the Arabization of the last name of the American president John F. Kennedy, whose name in Arabic appeared on the bags of wheat shipped to Yemen in the early 1960s. 
foreign white flour made it less profitable to grow wheat, even at the household level. Demand in urban markets for vegetables, such as potatoes and tomatoes, caused an increase in their production, invariably with pumpwell irrigation, but marketing was generally insufficient.

It appears that grape production, which is especially important in the Șa 'dah region, rebounded after the 1962 revolution. By 1998 Yemen ranked sixth among Arab countries for grape production, with increased production annually. In the 2003-2004 season, however, a major decline in grape production was reported, from 168,800 tons in 2003 to 104,100 tons in 2004 and a reduction in area from 22,200 ha to 12,000 ha (USAID 2005, 2). Most grapes are consumed locally, either fresh or as raisins. In 2003 Yemeni export of grapes amounted to only $4 \%$ of the total export of agricultural products. Efforts by the Tihāmah Development Authority led to an increase in tropical fruit production in the coastal region, especially bananas and papayas. Shelagh Weir $(2007,20)$ reports that bananas gained more commercial value in the 1970s since their leaves were used to wrap qāt in bundles.

The pace of socioeconomic change after the end of the Zaydi imamate in the north facilitated a rethinking of traditional status distinctions. Although sādah were integrated into Yemeni society following the civil war, they no longer had the level of prestige afforded them in the previous millennium, nor were they in principle under the protection of the tribes with the formation of the modern nation state. Tribes maintained their influence in rural areas, although the role of important shaykhs was often co-opted by the central government and tribal militias were created to counter what was often perceived as government interference. Officially, the traditional low-status groups were now afforded equal rights as citizens. The emergence of a cash economy lessened the dependence of such groups on the tribes. The demand for some services, like the music of the muzayyin, allowed some to accumulate wealth. Vegetables were no longer the exclusive domain of the qashshām. During the 1990s a village in Wādi al-Ahjur elected a qashsham as their shaykh, something that would not have happened during the imamate. Old status markers were still hard to overcome, as social barriers in marriage often continued (Kopp 1981, 141).

\section{The Future of Agriculture in Northern Yemen}

To predict the future of agriculture in Yemen is as fraught with uncertainty as planning the rebuilding of the state after the events of the disastrous campaign waged since 2015 by the Saudi coalition against the Hüthīs. The long and rich tradition of agriculture in South Arabia suggests that there is hope for sustainable production, but this will have to be with far more efficient use of the dwindling water resources. A major hurdle results from the large population, currently estimated as high as 28 million in 2018 and estimated to be over 47 million by 2050. The fact that the bulk of Yemen's population is still rural suggests that agriculture at the household level is not going to disappear soon. There is sufficient fertile land for production, but the overdrawing of groundwater resources severely limits expansion. The potential for increased dry farming, especially using runoff water harvesting techniques, is one of the few options available. Such agriculture would have to focus on traditional subsistence crops, which could at least provide food for the table. However, the reliance on food imports and loss of interest in the hard labor with minimal returns of past practices work against such a revival.

The current war that has created one of the worst humanitarian crises of the 21 st century and has so devastated Yemen's infrastructure and economic base negates virtually all the previous development efforts since the founding of the Yemen Arab Republic. The collapse of the state has resulted in an almost total inability of ministries to assist Yemen's agricultural systems. The expected massive pouring 
in of millions of dollars in post-conflict aid will not magically recreate a new verdant Yemen, especially given the likelihood of continued corruption due to the sheer amount of aid provided. The best hope for reviving agriculture in Yemen is to build on and improve the systems that were developed over centuries (Varisco 1995, 1992). This includes an expansion of water runoff harvesting, which was widely practiced in the pre-Islamic era, as well as more efficient use of wadi flood flow and spring systems. It is absolutely necessary to monitor groundwater extraction, but this will be one of the most difficult challenges facing the post-conflict government.

While some foreign observers routinely blame Yemen's problems on its tribal past, the centuries of tribal governance as the main civil society in rural areas and the role of customary law in resolving disputes over natural resources should not be dismissed. The set of values embedded in Yemen's qabyalah can serve as a basis for renewing the social contract in a country ravaged by conflict and outside intervention. The traditional value of cooperation at the local level, which stimulated most rural development in the 1970s and 1980s, can provide a safety net. Adapting long-standing tribal values to the needs of modern agricultural production can correct past policies that led to the loss of smallholdings and the consolidation of land by elites around unregulated tubewell systems. Building on the indigenous agricultural knowledge of Yemeni tribesmen that worked in the past does not mean returning to the past. ${ }^{17}$

The future of Yemen's current population, which is overwhelmingly young, must include a vibrant agricultural sector regardless of the obstacles. There are few other options for economic survival. Yemen's oil and gas production, severely curtailed by the current war, is limited; the income from this, even if not reduced by corruption and patronage, is not a solution. There is little opportunity for industrial expansion, especially given the reluctance of firms to invest in a country with such a conflictridden history and lacking in basic infrastructure. Since the expulsion of perhaps as many as 800,000 Yemeni workers from Saudi Arabia and the Gulf States in the first Gulf War, there is little demand for unskilled Yemeni labor in nearby countries. Concerns about terrorism also severely limit the ability of Yemenis, especially young men, to migrate outside of Yemen for jobs.

So what is the best way forward? More than anything else, the future of Yemen must be managed by Yemenis themselves and not by the dictated policies of neighboring countries and major development organizations. Regional politics and the dominant economic role of oil and gas work against the sustainable rebuilding of Yemen. The lack of leadership, with political operatives more interested in promoting their own agendas than the good of the people, does not bode well for the success of a future government. Should Yemen remain fragmented and not reunify, the future seems even more dismal. The current war has been particularly damaging to the northern parts of Yemen with the historic town of Șa 'dah decimated and most of the regional infrastructure, hospitals and schools damaged or destroyed. The psychological damage of trauma from the war, especially for children, is an additional negative consequence.

One ray of hope is the accumulated indigenous knowledge about Yemen for each microzone. While it is not possible to simply return to the traditional methods, largely a function of subsistence production, it is possible to improve local production at the household level and create sufficient surplus for local

17 An example is the indigenous Yemeni knowledge regarding plant protection methods, which reduces the need for imported and dangerous pesticides (Varisco 1995). 
distribution. Until such time as there is a government capable of providing assistance and effectively monitoring water extraction, production needs and marketing, the resilience of tribal customary law in the north can provide temporary relief. The Islamic principles of water resource use, when properly applied, were created to ensure sustainable use. Convincing young Yemenis to stay on the farm or take up farming may be a difficult task, but there are few other viable options for the majority. A millennium ago the Yemeni savant al-Hamdānī $(1983,317)$ called his homeland the Verdant Yemen (al-Yaman al$\left.k h a d r \bar{a}^{\prime}\right)$. It is well worth the effort, no matter how difficult in the future, to keep Yemen verdant with a sustainable agricultural system and the maximum of self-reliance that has sustained the people of Yemen throughout their history.

References

Abū Yūsuf, Ya qūb ibn Ibrāhīm (d. 113/731). 1885. Kitāb al-Kharāj. Būlāq: al-Maṭba a'ah al-Mīrīyah.

Adra, Najwa. 2013. The Impact of Male Outmigration on Women's Roles in Agriculture in the Yemen Arab Republic. FAO report. http://www.najwaadra.net/devrprts.html.

1997. "Dance and Glance: Visualizing Tribal Identity in Highland Yemen." Visual Anthropology 11:55-101.

al-Akwa', Ismā '̄il ibn 'Alī. 1984. Al-Amthāl al-Yamāniyyah. Șan à̃': Maktabat al-Jīl al-Jadīd.

al-Ameri, Ahmed. 2011. Regional Stable Isotope and Hydrochemistry Investigation in Yemen and in the Representative Area "Sana'a Basin." Ph.D. Dissertation, Institut für Geologische Wissenschaften, Freie Universität Berlin.

al-Asbahi, Qahtan Yehya A. M. 2005. Water Resources Information in Yemen. IWG-Env, International Work Session on Water Statistics, Vienna, June 20-22 2005. millenniumindicators.un.org/unsd/environment/envpdf/pap_ wasess3a3yemen.pdf.

Brandt, Marieke. 2017 Tribes and Politics in Yemen: A History of the Houthi Conflict. London/New York: Hurst/ Oxford University Press.

Donaldson, William J. 2000. Sharecropping in the Yemen: A Study in Islamic Theory, Custom and Pragmatism. Leiden: Brill.

Dostal, Walter. 1974. "Sozio-ökonomische Aspekte der Stammesdemokratie in Nordost-Yemen," Sociologus 24 (1): $1-15$.

Dresch, Paul. 1989. Tribes, Government, and History in Yemen. Oxford: Clarendon Press. 2006. The Rules of Barat: Tribal Documents from Yemen. Șan 'a'’' CEFAS.

Eger, Helmut. 1984. "Rainwater Harvesting in the Yemeni Highlands." Yemen Studien 1:146-169.

Giesecke, Craig. 2012. Yemen's Water Crisis: Review of Background and Potential Solutions. Washington, D.C.: USAID Knowledge Services Center.

Gingrich, Andre. 1994. Südwestarabische Sternenkalender: Eine ethnologische Studie zu Struktur, Kontext und regionalem Vergleich des tribalen Agrarkalenders der Munebbih im Jemen. Wiener Beiträge zur Ethnologie und Anthropologie, 7. Vienna: Institut für Völkerkunde.

Gingrich, Andre; Heiss, Johann. 1986. Beiträge zur Ethnographie der Provinz Șa 'da (Nordjemen). Vienna: Austrian Academy of Sciences.

Goitein, Shelomo Dov. 1934. Jemenica: Sprichwörter und Redensarten aus Zentral-Jemen. Leipzig: Harrassowitz.

Grohmann, Adolf. 1930-34. Südarabien als Wirtschaftsgebiet. 2 vols. Brunn: Rudolf.

al-Hamdānī, Abū Muhammad al-Ḥasan. 1983. Șifat jazīrat al- 'Arab. Edited by M. al-Akwa'. Șan'ā': Markaz alDirāsāt wa-1-Buhūth al-Yaman̄î.

Haykel, Bernard. 2002. "Dissembling Descent, or How the Barber Lost his Turban: Identity and Evidence in Eighteenth-Century Zaydī Yemen." Islamic Law and Society 9 (2): 194-230. 
Hovden, Eirik. 2006. Rainwater Harvesting Cisterns and Local Water Management. M.A. Thesis, Faculty of Mathematics and Natural Sciences, University of Bergen.

Ibn Miftāḥ, Abū al-Ḥasan 'Abd Allāh. 1938. Sharḥ al-azhār al-muntaz' min al-ghayth al-midrār al-mafātị̣ likamā' 'im al-azhār fì fiqh al-a 'imma al-ațhār. Cairo: Maṭba' at Hijāzī.

Kopp, Horst. 1981. Die Agrargeographie der Arabischen Republik Jemen. Erlanger Geographische Arbeiten, 11. Erlangen.

Lichtenthäler, Gerhard. 2000. “Power, Politics and Patronage: Adaptation of Water Rights among Yemen's Northern Highland Tribes.” Etudes Rurales 155/156:143-166.

2016. Political Ecology and the Role of Water: Environment, Society and Economy in Northern Yemen. London: Routledge.

MAF. 1983. Summary of the Final Results of the Agricultural Census in Eleven Provinces. San' $\bar{a}$ ': Ministry of Agriculture and Fisheries, Department of Planning and Statistics.

Maktari, Abdulla. 1971. Water Rights and Irrigation Practices in Lahj. Cambridge: Cambridge University Press.

al-Maqhafì, Ibrāhīm Aḥmad. 2002. Mu 'jam al-buldān wa-al-qabā'il al-Yamaniyyah. Șan'ā’' Dār al-Hikmah.

al-Māwardī, 'Alī ibn Muḥammad. 1960. Al-aḥkām al-sulțāniyyah. Cairo: Maṭba at Muștafā al-Bābī al-Ḥalabī waAwlādih.

Meissner, Jeffrey R. 1986. Tribes at the Core: Legitimacy, Structure and Power in Zaydī Yemen. Ph.D. Dissertation, Columbia University, New York.

Morris, Timothy. 1991. The Despairing Developer: The Diary of an Aid Worker in the Middle East. London: I. B. Tauris.

Mundy, Martha. 1979. “Woman's Inheritance of Land in Highland Yemen.” Arabian Studies 5:161-187.

— 1989. "Irrigation and Society in a Yemeni Valley: On the Life and Death of a Beautiful Source." Peuples Méditerranéens 46 (1): 97-128.

1995. Domestic Government: Kinship, Community and Polity in North Yemen. London: I. B. Tauris.

al-Murtạ̣ā, al-Mahdī li-l-Dīn Allāh Aḥmad ibn Yạ̣yā. 1975. Kitāb al-Baḥr al-zakhkhar. Beirut: Mu'assasat alRisālah.

Peters, Emrys. 1960. "The Proliferation of Segments in the Lineage of the Bedouin of Cyrenaica." The Journal of the Royal Anthropological Institute of Great Britain and Ireland 90 (1): 29-53.

Rathjens, Carl J. 1951. "Tâghût gegen scherī‘a.” Jahrbuch des Linden Museums, N.S. 1:172-187. Stuttgart.

Robin, Christian. 1978. "Le problème de Hamdān: des qayls aux trois tribus." Proceedings of the Seminar for Arabian Studies 8:46-52.

Rossi, Ettore. 1948. "Il Diritto consuetudinario delle tribù arabe del Yemen.” Rivista degli Studi Orientali 23:1-36. al-Samāwī, 'Abd al-Wahhāb ibn Muḥammad. 1974. Al-ta 'āmul fì al-Islām. Cairo: Dār li-1-Ṭibā'ah.

al-Sayāghī, Sharaf al-Dīn al-Ḥusayn ibn Aḥmad. 1968. Al-rawḍ al-naḍ̄r. Al-Ṭā’ if: Maktabat al-Mu’ayyad.

Tobi, Yosef. 1999. The Jews of Yemen: Studies in their History \& Culture. Leiden: Brill.

USAID. 2005. Grape Subsector Assessment Report for the Yemen Agricultural Support Program. Burlington, VT: ARD, Inc.

Varisco, Daniel Martin. 1982a The Adaptive Dynamics of Water Allocation in al-Ahjur, Yemen Arab Republic. Ph.D. Dissertation, Philadelphia, University of Pennsylvania, Philadelphia, Anthropology.

— 1982b. "The Ard in Highland Yemeni Agriculture." Tools and Tillage 4 (3): 158-72.

— 1985. "The Production of Sorghum (Dhurah) in Highland Yemen.” Arabian Studies 7:53-88.

— 1992. "The Future of Terrace Farming in North Yemen: A Development Dilemma." Agriculture and Human Values 8 (1/2): 166-172.

— 1994a. "Land Use and Agricultural Development in the Yemen Arab Republic." In Anthropology and Development in North Africa and the Middle East, edited by Muneera Salem-Murdock and Michael M. Horowitz, 292-311. Boulder: Westview Press. 
1994b. Medieval Agriculture and Islamic Science: The Almanac of a Yemeni Sultan. Seattle: University of Washington Press.

— 1995. "Indigenous Plant Protection Methods in Yemen.” Geojournal 37:27-28.

_2009. “Agriculture in al-Hamdān̄̄’s Yemen: A Survey from Early Islamic Geographical Texts.” Journal of the Economic and Social History of the Orient 52 (3): 382-412.

— 2012. "Qāt and Traditional Healing in Yemen.” In Herbal Medicine in Yemen, edited by H. Schönig and I. Heymeyer, 69-102. Leiden: Brill.

- 2018. The State of Agriculture in the Mutawakkilite Kingdom of Yemen, 1918-1962: A Documentary Overview. Österreichische Akademie der Wissenschaften/Austrian Academy of Sciences, AAS Working Papers in Social Anthropology 32. http://epub.oeaw.ac.at/wpsa32.

Vogel, Horst. 1988. "Impoundment-Type Bench Terracing with Underground Conduits in Jibal Haraz, Yemen Arab Republic." Transactions of the Institute of British Geographers, New Series, 13 (1): 29-38.

Ward, Christopher. 2014. The Water Crisis in Yemen: Managing Extreme Water Scarcity in the Middle East. London: I. B. Tauris.

al-Wāsi '̄̄, 'Abd al-Wāsi' ibn Yaḥyā. 1948. Tārīkh al-Yaman. Cairo: Maṭba 'at Hijāz̄̄̄.

Weir, Shelagh. 1985. Qat in Yemen. London: British Museum Press.

2007. A Tribal Order: Politics and Law in the Mountains of Yemen. Austin: University of Texas Press.

YAR. 1983. Summary of the Final Results of the Agricultural Census in Eleven Provinces (Dhamar, Hodeidah, Hajjah, Mahweet, Taize, Ibb, Sa'ada, al-Beida, Sana'a, al-Jawf and Ma'rib). Șan 'à': Department of Planning and Statistics, Ministry of Agriculture and Fisheries.

— 1974-1975. Statistical Year Book. Șan 'à' : Yemen Arab Republic, Central Planning Organization.

Zayd ibn 'Alī (d. 122/739). 1966. Masnad al-Imām Zayd. Beirut: Dār Maktabat al-Hayāt. 



\title{
MUNEBBIH'S NORTHWESTERN BORDERS THROUGH THE $20^{\mathrm{TH}}$ CENTURY
}

\author{
Andre Gingrich
}

Any nuanced and balanced academic understanding of tribalism in southwest Arabia during the $19^{\text {th }}$ and $20^{\text {th }}$ centuries up to the present requires examination of different perspectives. While seeking to agree on a main set of useful working definitions for tribes and tribalism in these Yemeni contexts - not an easy task in its own right ${ }^{1}$ - scholars therefore have to recognize the validity and richness of these different perspectives, at least in so far as they relate to fluid and multi-facetted ethnographic realities.

\section{Introduction}

Anthropological research since the 1980s has focused on various aspects for elucidating the tribal phenomena under scrutiny in Yemen. Scholars have analyzed a wide variety of crucial dimensions, such as the agency of tribal leadership (Dresch 1989), or specific courses of events and processes within their contexts in the past (Heiss 2018) and the present (Brandt 2017). Other authors have focused very appropriately on tribal and non-tribal material conditions and related expertise (Varisco 1983, 2009; Gingrich and Heiss 1986a), on tribal idioms and genealogies (Heiss 1998; Varisco 2017), on the fluidity of contested social interactions (Weir 2007), or on artful performance in dance (Adra 1998, 2016) or poetry (Caton 1993) for exploring tribal norms and values. This subtle and sophisticated pluralism of perspectives and its ensuing rich harvest of ethnographic and historical insights indeed belong to the best that anthropology and its neighboring fields have had to offer for assessing tribes and tribalism in the region. The present text is firmly rooted in this particular pluralist and ethnographically informed research legacy of more than two generations of socio-cultural anthropologists. While this chapter in a way is a tribute to that legacy, it also takes its main inspiration from it for proposing some advances and innovations.

In a nutshell, the following text ${ }^{2}$ seeks to enrich the pluralism of perspectives by adding the dimension of tribal experiences from the periphery, in two senses of that word. I will discuss Munebbih ${ }^{3}$ tribal

For Yemeni contexts I usually prefer the indigenous definition: i.e. those major social units locally referred to as qabīlah; see also my IESBS entry (Gingrich 2015).

2 I thank Marieke Brandt (ISA at the OeAW), as this volume's editor and host of the conference preceding it, for her valuable feedback. The helpful comments by all conference participants are appreciated, in particular by Steven C. Caton (Harvard). I also gratefully acknowledge the helpful suggestions and assistance provided by Mehmet Emir, Johann Heiss (both: ISA at the OeAW) and Dave Westacott concerning an earlier version of this chapter.

3 The present text uses a simplified version of IJMES transliteration rules except for the accompanying map (relying on an earlier publication in German, and therefore using the German DMG transliteration system). Additional exceptions include Anglicized terms (e.g. Zaydīs, Ḥūthīs) and a few instances of my own versions for the vernacular forms of local names (e.g. am Jalsa, Munebbih). 
perspectives, that is, views from a Khawlān al-Shām tribe ${ }^{4}$ in Yemen's most remote northwest corner. Within the Munebbih, my focus will, in turn, be on their even more peripheral section of 'Ayyāsh in the hilly western and northwestern parts of Munebbih territories bordering the B. Mālik to the west (today on Saudi territory). This (inter)tribal border, later on also a state border, will thereby be at the center of my discussion throughout this chapter's three main parts: following this introduction, the second part will outline some insights on the 'Ayyāsh borderlands from my Munebbih fieldwork in the 1980s. In the third part, I will then try to assess the impact of state influences on the local intertribal border situation in this particular section during three consecutive transformation processes in the $20^{\text {th }}$ century. The three processes of border changes addressed in this third part are:

1. the end of Ottoman rule and the subsequent Idrīsi presence after the end of WWI;

2. the results of the Saudi-Yemeni war of the 1930s with its subsequent ceasefire and border commissions; and

3. the consequences of the 1962-1970 Yemeni civil war with its implications for the northwestern Munebbih border along their 'Ayyāsh section's territory.

Finally, this chapter's fourth part will briefly offer some conclusions from the previous analysis with a focus on the periphery in tribal territoriality, on intertribal border zones and with regard to specific aspects of tribal honor in these contexts. A summary will then, fifth, comment on the local situation during the current conflict at the time of writing (i.e., in early 2019), by addressing certain long-term features of intertribal and state relations in this particular region in contexts of recent and contemporary history.

\section{Fieldwork Insights on the 'Ayyāsh Section of Munebbih}

Readers may or may not recall from previous publications (e.g., Gingrich 1993) that the Munebbih basically inhabit one of the high, isolated mountains more than $2000 \mathrm{~m}$ above sea level situated in the eastern Tihāmah - i.e., the coastal lowlands along the eastern Red Sea shores - immediately in front of the highlands' actual plateaus and mountain ranges. The upper tributaries of the Wādī (flood valley, here: W.) Jīzān (or: Jayzān, also: Jāzān) and of the W. Ḍamad are adjacent to the lower slopes of the Munebbih mountain (Jabal, or J. Munebbih) on its north and south sides respectively. Still referred to as al- 'Urr in al-Hamdānī's times ( $10^{\text {th }}$ century CE), J. Munebbih is situated between J. Fayfă' to the west and J. Rāziḥ to its south, but it is far less accessible from the outside than J. Rāziḥ.

As in most cases of these isolated mountains in the eastern Tihâmah, throughout the $19^{\text {th }}$ and $20^{\text {th }}$ centuries the majority of the Munebbih resident population inhabited the most fertile upper ridges and slopes. Wherever possible, terraced fields cover the mountain surface from its highest elevations (except for the highest mountain peak al- 'Urr, see Gingrich 2002 and 2012) to its lowest slopes, with ensuing environmentally based variations. In general, the residents of the upper and western slopes

This vernacular reference to the "northern" Khawlān was by far the most commonly used verbal designation during the 1980s. By its implicit distinction against Khawlān al-Ṭiyāl (to the east of Șan' 'à') the term Khawlān al-Shām basically implies a regional focus. Since the 1980s, however, together with changes in literacy and the media landscape, the designation Khawlān b. 'Āmir has come to be more commonly used. This shift reflects explicit allusions to genealogical time (as opposed to tribal space) and to literary sources. 
mostly enjoy healthier and somewhat safer lives as well as better agricultural yields than those living on the eastern and lower slopes. The inhabitants of low-lying slopes usually have better but more exposed access to communication lines toward the outside world, while animal husbandry also plays a greater role for them.

The tribal section of 'Ayyāsh primarily live in the lower, hilly western and northwestern parts of Munebbih territory between 500 and $900 \mathrm{~m}$. above sea level. A few scattered parts of their section's high territories, however, extend up to areas just below J. Munebbih's second highest peak, i.e. its northern summit, J. am Khudhullah. Otherwise, however, their main tribal territories lie right on the lower mountain slopes and at their foot above the upper banks of W. Damad and its tributaries (for a rough overview, see the map accompanying this chapter). Growing $q \bar{a} t$ or coffee is not possible here. The cultivation of cereals (primarily sorghum and emmer) and of garden products, however, is yielding rich results. Primarily this is based on the good usage of sayl (seasonal flood) runoff and of regulated floods, but it also relies on well-maintained cisterns and a number of springs. The 'Uyyūn 'Ayyāsh (i.e., 'Ayyāsh springs) in fact are quite famous in the region, representing this section's special pride, with the thermal springs of am Waghra in W. Qaffa right at the border being the best known among them. The 'Uyyūn 'Ayyāsh provide additional income for many residents, because, in peaceful times, they also represent a point of attraction for visitors even from the wider regional neighborhood, as was already pointed out to Philby $(1952,542-44,546)$ in the 1930s.

Some of these springs provide hot mineral-water basins within small sub-tropical gardens (Gingrich 1989: 41, 69). They have been a travel destination of hope and fascination for many people from all over the region seeking treatment and healing, especially for women hoping to fall pregnant. With Mislān as the main 'Ayyāsh settlement, more than two dozen small, fortified villages and hamlets on hilltops overlook fairly large and shallow terrace areas, which then intersect at the outer margins with vast zones of grazing grounds. All 'Ayyāsh households are sedentary hoe-and-ard horti- cum agriculturalists, but they also raise goats, sheep, camels and mules. By contrast, the closest neighbors of 'Ayyāsh to the west, the B. Mālik - and, in particular, two of their subsections - are mostly semi-nomadic inasmuch as they cannot regularly rely on shifting hoe cultivation, but primarily raise small livestock.

In terms of tribal affiliation, the 'Ayyāsh are composed of two subsections (am Mushammar and am Hilf). One of these has more land on the lower slopes, and consequently a longer part of the intertribal border. Nevertheless, the other section also controls a smaller, albeit significant, part of the Munebbih northwest border with the outside world, while most of their lands lie at somewhat higher elevations.

All the 'Ayyāsh are part of the Munebbih's Sha'sha' moiety, and together with all of the Munebbih, they belong to the Furūd tribes of Khawlān al-Shām. By contrast, their western neighbors from B. Mālik belong to the Yahāniyyah tribes of Khawlān al-Shām (Gingrich and Heiss 1986b, 46, 56; Gingrich 1989, 159-164). Immediately above most of the 'Ayyāsh territories, the slopes are too steep and barren for any other Munebbih settlements. In that sense, the 'Ayyāsh have represented the somewhat isolated but fairly powerful Munebbih outpost section to the low-lying northwest. The 'Ayyāsh do not have one overall section chief, but the two subsections' chiefs are reported to have mostly collaborated with each other quite well.

At the time of my fieldwork, the 'Ayyāsh were clearly much more affluent economically and stronger in demographic and military terms than their semi-nomadic B. Mālik neighbors below them. In fact, during my fieldwork phrases like "those below us who are living up here in 'Ayyāsh country" were not only an occasional expression of social distinction about other residents in the adjoining lower Tihāmah lands. This was also a visual reference, whenever my hosts sat down with me in the evenings on the 
roofs of their towers and houses. While drinking tea and discussing the rising and setting of stars as my main research interest at the time, we also contemplated and interpreted the landscapes below us. "This is all Khawlān country" was the consensual phrase, and fingers described the huge ranges from J. Fayfā' a distance away in front of us, across B. Mālik country below us, to J. Munebbih behind us where - in our upward perspectives - wall above wall of terraced fields looked like an insurmountable stone fortress for anybody approaching from the west. "Down there far below us" in the dry intertribal border zones with small fields and large pastures, a single tree provided ample shade in the evening light. Shajjar am $\mathrm{Jalsa}^{5}$ indicated a specialized neutral zone for meetings and negotiations, set aside right along the 'Ayyāsh and Munebbih intertribal border with their northwestern neighbors.

In addition to this neutral meeting ground, the intertribal borders along major parts of this section ${ }^{6}$ were to an extent openly permeable. Interactions across the intertribal border were regulated by customary law contracts, and mostly related to grazing rights. In the long run, these local border contracts between the 'Ayyāsh and some of the neighboring subsections from B. Mālik either had to be renegotiated, or they could be confirmed and continued whenever necessary. Sometimes renegotiations were preceded by violent clashes, but mostly they followed mere threats or tensions under peaceful circumstances. On a few occasions these renewals of local border contracts were even enhanced and strengthened through intertribal marriage. These border renewal contracts were signed by the shaykhs of the different subsections involved and by additional local guarantors from elsewhere in the immediate neighborhood. Only a few of these intertribal border renewal contracts were also signed by the two shaykh al-shamal (i.e., paramount tribal chiefs) of the Munebbih and the B. Mālik, but hardly ever by the distant representatives of the Zaydī and Sunni religious elites (e.g. on J. Rāziḥ or in the coastal Tihāmah (Dostal 2011).

Not a single unit of police, customs or army was mentioned or became visible between J. Fayfä' and the lower slopes of J. Munebbih during the mid- and late 1980s. This was something of a contrast to the low border zones of J. Rāzih to the south, where Johann Heiss and I had visited a somewhat dilapidated and neglected Yemeni state border control post in a low-lying western Rāziḥ section in 1983.

\section{Historical Vignettes of 'Ayyāsh Border Constellations}

This third part briefly examines three historical vignettes from the $20^{\text {th }}$ century related to changing intertribal border sections and alternating states' influence in the 'Ayyāsh area.

Vignette 1: Late Ottoman and Idrīsì Period, 1900-1924

Following the Ottomans' 1848 establishment of their (second) period of colonial administration in the region, they sought to provide a regional infrastructure that suited their commercial and military interests. Between the Tihāmah's Red Sea shorelines and the high mountain ridges and plateaus of southwest Arabia, Ottoman initiatives opened and maintained a number of fortified supply routes in a

5 See Behnstedt 1987, and examples for as well as modifications to Behnstedt's rough outline in Gingrich 1989: 168-172, 576-578 (notes 126-138), for specificities in the Munebbih vernacular. These also include the (wider regional) prevalence of $i m$ or am as the definite article.

6 As discussed in historical vignette 2 of this chapter's next section, other parts of this border continued to be regulated more strictly at the time of my fieldwork sojourn. This was the enduring outcome of a contract element from the later part of the 1930s, following the ceasefire agreement and its implementation procedures after the Saudi-Yemeni war of those years. 
general west-east direction. This type of quasi-colonial development accelerated especially after the opening of the Suez Canal in 1869 (Blumi 2010). One of these new fortified routes went via Mìdī to Rāziḥ, another led from Jīzān via Abū 'Arīsh to Abhā. From the 1870s and 1880s, the Ottoman administrative and military presence was therefore active in the wider vicinity to the west, south (coast and routes via Rāziḥ) and east (Șa 'dah and outposts) of Munebbih territory, thus having an impact upon supply lines and goods of relevance for them. Nevertheless, apart from this circulation of new goods I am aware of no extant record of any immediate administrative or military Ottoman presence in the rough intertribal terrain between J. Fayfă' and 'Ayyāsh or Munebbih in general. Taxation paid to the Ottomans may have occurred very occasionally through tribal leaders, while Zaydī religious or legal influence was also minimal. Old hosts of mine said in the 1980s that their grandparents had referred to the late Ottoman years as very peaceful. The Ottomans seem to have left the 'Ayyāsh essentially to themselves to pursue their tribal interests, I was told, and health tourism to the 'Uyyūn 'Ayyāsh flourished, even by families coming from as far away as Jizān and al-Hudaydah. In addition, some of my hosts referred to local families' histories that also included extra income sources from transporting coffee (acquired from the upper Munebbih slopes and through related local markets) and selling it to coastal merchants. From these local accounts it is possible to tease out a growing 'Ayyāsh entanglement in regional and trans-tribal commercial activities, within a much wider but partially loose Ottoman administrative network over the entire region.

After Ottoman rule in 'Asīr, Jīzān and Yemen collapsed in 1918, the Idrīsī (i.e. Muhammad ibn 'Alī and, as of 1923, al-Hasan) sought to establish themselves not merely spiritually, but also as a (small) buffer principality in this region. To an extent this was realized primarily in the coastal areas between the Zaydīs - now newly in control in the southeast - and the re-emerging Āl Sa' ūd power (Wahhabis) in the north and northwest. The Idrīsī managed to sustain their regional mini-state with some limited success until the late 1920s, but they came under increasing pressure from the Saudis until gradually giving in by 1930 (Baldry 2015; Bang 1996). In the sense that the Idrīsī realm in the Khawlān alShām western areas extended from the coast around Jīzān in the west to the peaks of Munebbih in the east from 1919 until the late 1920s, the Idrīsī mini-state did in fact operate for a brief decade as a regional state successor to the Ottomans. For some time the Munebbih leadership accepted that 'Ayyāsh supplied and supported Idrīsī forces, perhaps also in view of continued tourism from the coast to its hot springs. The Munebbih shaykh al-shamal Ibn 'Awfān even hosted a tiny Idrīsī armed force on top of its main mountain peak al- 'Urr with an eye to keeping the Zaydīs to the east (Jumā'ah) and south (Rāziḥ) at bay. That small Idrīsī outpost built a stone cistern on the al-'Urr plateau, which was shown to me as testimony to the friendly features in Idrīsi-Munebbih relations. Yet in sum, the fragile, brief and volatile Idrīsī presence among the 'Ayyāsh and Munebbih did very little to actually change the intertribal border zone - which is precisely one of the reasons why both the Ottoman and Idrīsī presence were still remembered with some sympathy in the days of my fieldwork. By and large, it seems that the 'Ayyāsh experienced Ottoman and Idrīsī activities in their region as encounters with "states as distant umbrellas," gradually approaching local arenas but primarily protective of them from afar, leaving most local affairs to the locals but controlling some of the wider infrastructure (see also Blumi 2009). It is also noteworthy that both the more distant Ottoman as well as the less distant Idrīsi presence represented variants of Sunni theological orientations that primarily advanced from the west and locally encountered some sympathy. That local sympathy for "Sunnis to the west" corresponded to the fact that those "states as distant umbrellas" had left the Munebbih intertribal borders along their "Ayyāsh section undisturbed and intact on the ground. 
Vignette 2: From the 1934 War to Philby's Border Commission

The main components of the 1934 Saudi-Yemeni armed conflict have been analyzed repeatedly as to its crucial motivations, sequences, outcome and consequences (e.g., Baldry 1985; Dresch 2000). While proWahhabi military and tribal forces moved southward in the Tihāmah (i.e. beyond Mīdī toward al-Hudaydah) as much as in the highlands (down to Abhā, Zahrān, and Najrān), the tribal leadership of the Munebbih declared that they would defend their territories "against the invaders from Riyāḍ," as they phrased it." They also indicated their readiness to accept Zaydī support. By contrast, the Ahl Fayfă' signaled their readiness to cooperate with Ibn Sa 'üd's forces as long as their local habits were respected - which is why they were subsequently allowed to continue growing $q \bar{a} t$ until at least into the 1990s. Meanwhile, the B. Mālik by reputation seem to have declared their own stand as "neutral." Consequently, the Fayfă' and B. Mālik territories, at first merely in a formal and superficial sense, thereby became part of the young Saudi kingdom's new southwestern territories. By contrast, the Munebbih - at first also merely in a similarly superficial sense - remained in the other new post-Ottoman realm of the recently independent northern Yemeni kingdom, whose centers had been controlled by the Zaydī Imams since 1918.

Several years later, as a by-product and result of the Yemeni-Saudi armistice negotiations and ceasefire agreement of 1934, a Saudi border commission led by King Sa ūd's adviser H. St. J. B. Philby sought to establish and demarcate the provisional state border on the ground. Actually, this state contract-based ceasefire line in the region was marked by means of numbered stone pillars (Philby 1952: 507, 515, 541), most of which had disappeared during the time of my fieldwork in the 1980s. In the absence of any other state representatives or corresponding documents related to local contexts, that Saudi border commission mostly relied on existing intertribal 'urf contracts, or on intertribal negotiations imposed by the commission itself, along the entire western Munebbih tribal border including 'Ayyāsh. In doing so they also changed rights over two major grazing grounds. Until then these two pastures had been basic 'Ayyāsh property with renewable usage rights for the B. Mālik. Now, the border commission promoted their transformation into permanent B. Mālik property under 'urf and bilateral state law. The chiefs of all subsections involved signed the relevant documents, as did the two shaykhs al-shamal concerned, together with nominated state representatives from the region. If I am not mistaken, then this must have been one of, if not the first occasion when 'Ayyāsh representatives were informally assigned the task of henceforth guarding the ceasefire line along their section not only for themselves and the Munebbih, but also for the distant Zaydī imamate state's centers. The 'Ayyāsh had been entrusted with a new task - that is, acting as informal and semi-official guardians of a contested state frontier.

In turn, the accomplished redefinition of the relevant border section resulted in a small but clear expansion of B. Mālik territory on behalf of the Saudis, to the disadvantage of 'Ayyāsh for Munebbih and Yemen. Other intertribal grazing rights across the ceasefire line in this region (involving other Munebbih sections) were left as they were by the commission. The previously strong Munebbih outpost position by 'Ayyāsh, however, was limited and confined in these two parts (and another, smaller one) of the intertribal border. Seen from the 'Ayyāsh perspective, this certainly represented a case when the young Saudi state served as a substantial force in support of their B. Mālik opponents, while no other tribal or state force

These accounts rely on Italian summaries of contemporary developments in the (pro-Mussolini) Italian journal Oriente Moderno, 1931-35. Those printed overviews were primarily authored by the well-known Arabist and Yemen expert Ettore Rossi, who obviously relied on local agents on the Zaydī side and their reports to him. 
had effectively stepped in to support the 'Ayyāsh. In theory at least, this 1936/7 border redefinition also transformed parts of a fluid territorial boundary into a state line, which henceforth could be used to cut off the 'Ayyāsh from their long-established connections to the western lowlands. In practice, however, the changes were less dramatic. B. Mālik could merely continue their use of those pastures but now without consulting with the 'Ayyāsh-and the 'Ayyāsh continued all their other tribal transactions across the ceasefire line throughout the following thirty years, until the imamate began to collapse.

\section{Vignette 3: 'Ayyāsh during the 1962-70 Civil War}

Early on in northern Yemen's civil war of the 1960s, shaykh al-shamal Ibn 'Awfān declared that Munebbih would remain neutral in the ongoing conflict (Gingrich 1993). To a significant extent, this had to do with the fact that until then the Munebbih had actually never accepted any sādah presence or settlement on their territory, and in fact continued not to do so thereafter. Although Munebbih suffered from some Egyptian air raids because of their neutrality, remaining neutral during the early phases of the civil war simply continued that basic stand of keeping the Zaydī sādah at bay. By the mid-sixties, Ibn 'Awfān then openly sided with the distant republican government in Șan 'à'. The secular and weak republic represented a more interesting ally, in particular since the neighboring Khawlān al-Shām tribes to the south and east (i.e. Rāzih and Jumā'ah) continued to be closely allied with the royalist cause.

During that period, before and immediately after the 1967 Egyptian withdrawal from the civil war, 'Ayyāsh effectively helped to cut or block all efforts at supplying arms from the Saudi Red Sea coast to the royalists' remaining strongholds on the plateau. Not for the first time in their history, armed raids and guerrilla expeditions thereby became part of the Munebbih image as fearless and dangerous warriors in the wider region. Because of their exposed position and their familiarity with the hilly western Tihàma terrain, 'Ayyāsh played a significant role in those armed anti-royalist guerrilla campaigns along and beyond the ceasefire line.

For many years - in fact, for two decades until the time of my own fieldwork - the Munebbih therefore came to be known as the republic's most reliable if not exclusive tribal ally in the northwest. With the end of the civil war, the republic's position gradually stabilized. During the early 1970s, the Șan' $\bar{a}$ ' government officially upgraded several tribal chiefs in the northern provinces, Ibn 'Awfān for Munebbih among them, as official border guardians on behalf of the republic. Eventually, this went together with regular payments from Șan' $\bar{a}$ ' for Banū 'Awfān, who redistributed substantial parts of those sums to the chiefs of subsections along the ceasefire line, such as those of 'the Ayyāsh. Local tribesmen were thereby in some sense promoted by and on behalf of the state - if not partially integrated as auxiliary tribal state forces in the absence of the distant state's regular forces.

Henceforth, armed 'Ayyāsh tribal members would not merely act as guardians of their own western border as the entire tribe's border zone, but also as semi-official guardians of the Yemeni republic's northwesternmost border. Although on the ground this was as invisible as Eric Wolf's (and John Cole's) proverbial "hidden frontier" (Wolf and Cole 1974), the contracts from 1937 and from 1972 were still in effect during my fieldwork sojourn, and cash continued to flow from Șan ' $\bar{a}$ ' through the Munebbih shaykh al-shamal to the 'Ayyāsh shaykhs.

Once again during the $20^{\text {th }}$ century, 'Ayyāsh and Munebbih had thereby redefined their position regarding their border with the B. Mālik. From a fortified, neutral tribal enclave under siege between the royalists and the republicans in the early days of the civil war, they were now promoted to quasiofficial state guardians of that border, or, as they preferred to see it: they continued to take care of their own border with some additional help from a distant state as their ally. 


\section{Conclusions}

We have seen through the 'Ayyāsh example that the tribal border usually features no specialized, manmade markers on the ground, but rather renewable contracts on shared usage rights combined with occasional symbolic natural landmarks for orientation and neutral zones, such as the "Shajjar am Jalsa." We also saw that in terms of agreements, all contracts are signed by the representatives of local sections and subsections, sometimes together with the shaykh al-shamal or his plenipotentiary. This sheds some additional light on the contractual status of tribal representatives. The signatures on contracts redefining intertribal border sections imply that legally and symbolically, the representatives of (sub-) sections in border regions not only have to stand for their personal as well as their (sub-) section's honor, but more frequently than others also for their overall tribe's collective honor. After all, a tribe's territorial integrity is also part of a tribe's name, standing, and reputation.

In principle, it is valid for any Munebbih tribal man (and in a somewhat different way also for a tribal woman) that they not merely represent and defend their personal honor and reputation but also that of their family, (sub-) section, and sometimes, of the entire tribe if facing challenges from members of other tribes. Yet in practical terms, the challenge to defend one's overall tribal honor occurs only rarely for average Munebbih tribal members, since the majority of them live in the densely populated highest mountain ridges. Consequently, they would only occasionally face external challenges to their overall tribal affiliation and its name, such as on market days, during military campaigns, or while peacefully travelling elsewhere. By contrast, the shaykh al-shamal and his personal representatives (from Banū 'Awfān, such as one of his brothers or sons) and the tribal member from an intertribal border section such as 'Ayyāsh regularly have to engage with external challenges to overall tribal honor. They answer to this task, however, from different relational positions and hence by different means.

A high-ranking Banū 'Awfān member represents a chiefly lineage whose members have been "protected" by all major sections of the Munebbih for at least four centuries. The tribal protection for the paramount chiefly lineage implies that they need protection - in a strict sense, they are supposed primarily to stand up not for their narrow personal interests but for overall tribal interests to the outside (i.e., vis-à-vis other tribal leaders or governments) as well as internally (by mediating and solving internal tribal conflicts at the highest level). The need for continuous tribal protection for the Banū 'Awfān, for their permanent overall tribal representation, becomes symbolically and materially evident in the escorts. These armed guards are composed of Banū 'Awfān and armed tribesmen, who always accompany the shaykh al-shamal on his missions (Gingrich 2011). Ibn 'Awfān therefore never himself fights with arms, but only by means of law and diplomacy. He represents overall tribal honor that is transferred to him by the sections' commitment to protecting the paramount chiefly lineage. In this sense, the shaykh al-shamal's main task in representing overall tribal honor is the maintenance or establishment of peaceful solutions.

This is not the primary assignment of those tribal members such as the 'Ayyāsh, who live along an intertribal border zone. Differing in this regard from the Banū 'Awfān and the majority of average tribal members in the central and upper Munebbih territories, the 'Ayyāsh are rarely confronted with any intra-tribal tensions or conflicts. Yet similar to the Banū 'Awfān, they more or less regularly face external challenges to which they have to answer for themselves and, simultaneously, for the overall tribe and its territorial and symbolic integrity. What for an average tribal member may occur only occasionally while otherwise being just a theoretical principle is therefore a regular element of tribal honor on the territorial periphery. Along the intertribal border, tribal members regularly have to answer external challenges in peaceful or violent ways, addressing them and defending their (sub-) section's as 
well as the overall tribal integrity, name and reputation. This implies a potential for the emergence of tribal war leaders, who may temporarily become military leaders for larger tribal groups of armed units.

A number of additional features underpin and inform these specificities of intertribal borders and their interface with conflict, peace, and contracts. In a spatial and temporal sense, tribal borders include broader zones of mutuality and of neutrality, as well as shorter time rhythms for renegotiations or renewals. This is implied in the short annual or biannual cycles for renegotiating co-usage of grazing grounds, and for more enduring border changes after armed conflicts. The notion of a more volatile, broad, frayed and permeable border "zone" thus might be more appropriate for intertribal borders, ${ }^{8}$ in contrast to ideas about any enduring intertribal border "lines" in space.

For the different forms of state interventions in this particular area during the $20^{\text {th }}$ century, the present text has addressed various manifestations of state agency: A first historical vignette discussed gradually approaching "state umbrellas" before the mid-1920s. First elements of new states appearing as an "auxiliary force" on one side at the expense of the other in intertribal affairs of the mid- and late 1930s were identified in the second vignette. This highlighted ensuing transformations of provisional and flexible 'urf contracts into supposedly permanent treaties, including linear instead of zonal claims (between numbered stone pillars) on the ground. The third vignette from the Cold War period demonstrated, first, how the local presence of states as auxiliary forces expanded, but also how local tribal sections were transformed more intensely than previously into auxiliary forces for states in the region. This also included the contractual and financial integration of tribesmen as guardians not only of their intertribal border but also, based on that, as official republican border guardians - while in fact they sought to continue treating the border as a zone rather than a line.

A certain gradually increasing presence in the region by various states therefore cannot be denied, if these three vignettes are compared over the flow of regional history between the 1880s and the 1980s. Yet this progressively linear aspect of a general increase in state presence is not the only tendency that becomes apparent - and perhaps not even the most important one. In addition to the linear tendencies of increasing state presence, one may also detect fractures and breaks interrupting any linear advancement of state influence from whatever side. Some of these ruptures were unique, but several of them displayed strong elements of redundant rhythms over time that recall the French bon mot "plus ça change, plus c'est la même chose." They suggest alternating but recurrent cycles of peripheral tribal agency with state interventions in the region.

Sometimes, state claims on intertribal border zones may turn out to be highly compatible with tribal aspirations, as was the case during the Idrīsin interlude as well as during my fieldwork in the 1980s. These were two periods when the state powers in question sought stability for themselves during periods of weakness in their distant centers. At times, however, tribal and state interests in the region have, in fact, been almost irreconcilable, such as during the civil war of the 1960s or during the Hūthī wars and the ensuing Saudi involvement since 2015. In these almost irreconcilable constellations, shifting alliances between local tribal leaderships (that themselves changed in the course of events) and specific state interests as pursued on the ground and (since the 1960s) by air, as well as by changing media outlets, became the notorious general pattern of interaction.

Philby's $(1952,548)$ description of the phenomenon in the same region used the wording that "the tribal areas on either side were running in complicated strips". 
Within today's contexts of the wider confrontations between the Hūthīs and the Saudis and their respective supporters in the north and beyond, for all I know the Munebbih territory has basically been cut up. These are now two artificially separated tribal subterritories under opposing military and religious influence, with a small neutral zone under Banū 'Awfān administration in the middle. In fact, the Banū 'Awfān have turned out to be the one chiefly lineage in the entire (Yemeni side of the) Khawlān al-Shām region who have managed to remain in office, while most other established chiefs' families have been driven out in the course of the Ḥuthī wars (Brandt 2014). The Banū 'Awfân's resilience, and the tribal majorities' willingness to identify with them and support them, thereby defines a potential for a future symbolic and material Munebbih integrity amid factors opposing such potentials. After all, tribal administrative and political partition is continuing at the time of writing.

The easternmost, low-lying slopes of Munebbih (facing Jumā'ah) are controlled by Hūthī supporters, whereas the west with "Ayyāsh is part of a formally "demilitarized" zone imposed by Saudi military forces. Effectively they seem to be controlled by groups promoting a stronger and more enduring Saudi presence. As encountered by most resident groups in the region, previously unknown threats of observation and military drone strikes have to be coped with by the Munebbih sections on both sides. Simultaneously, and for the first time in their history, 'Ayyāsh have been transformed into lukewarm Saudi auxiliary forces. It seems that women attending 'Uyyūn 'Ayyāsh has been prohibited, and it remains doubtful whether the nearby Saudi military presence will invite any new visitors from the coast.

These are definitely times when tribalism and state influences in such intertribal-cum-state border areas do not co-exist well with each other at all. In one way, the current "territorial division of Munebbih" maybe has to be seen as a radical implementation of what had informed the intentions of state interventions all along in these border lands, ever since the early $20^{\text {th }}$ century: basically, they always followed a hegemonic "divide and rule" general state logic. In another way, however, the current "territorial division of Munebbih" may very well be seen as just as provisional and temporary as all the other previous state interventions have been since the 1870s - waxing and waning, coming and going. 


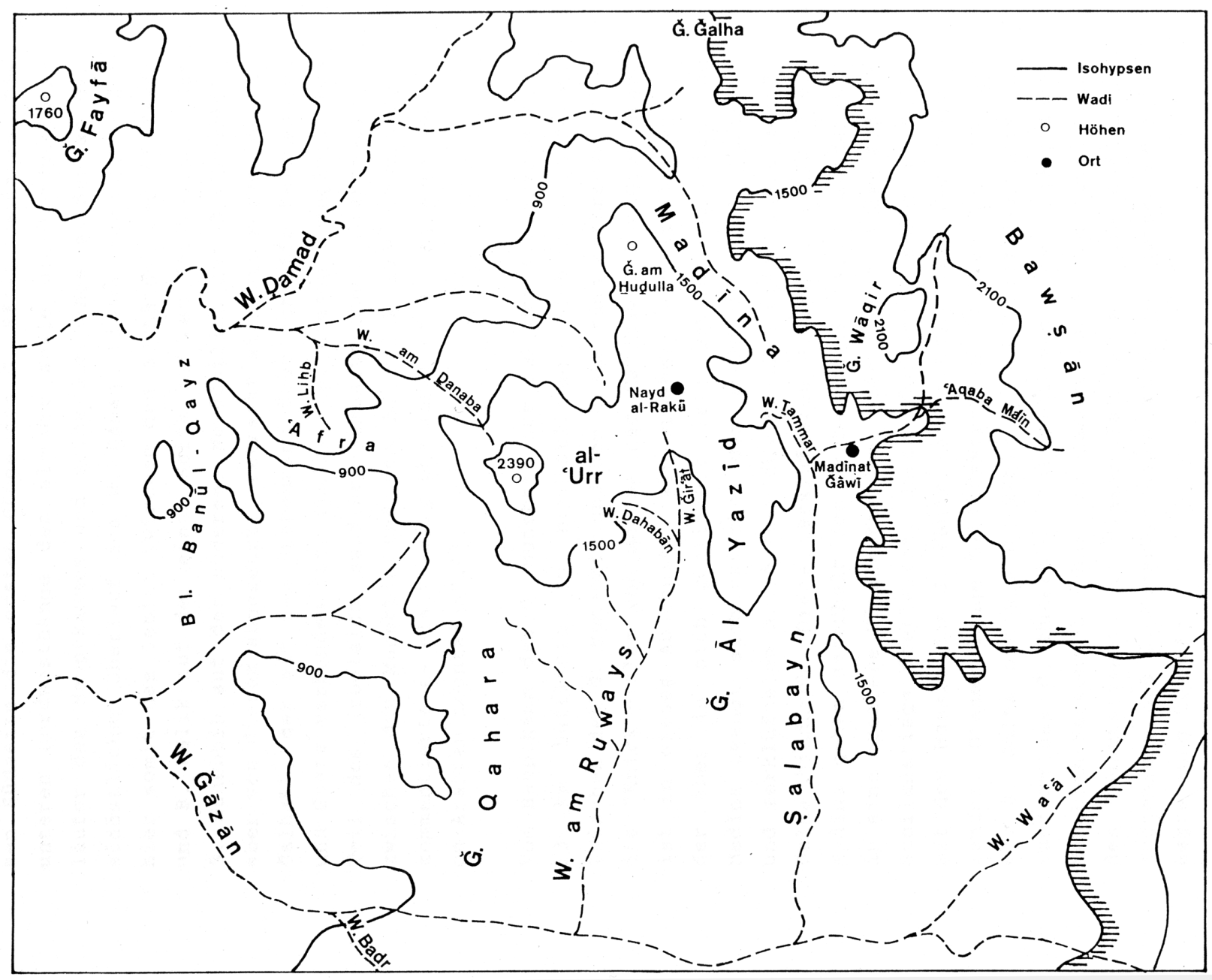

Map: Jabal Munebbih

\section{References}

Adra, Najwa. 1998. "Dance and Glance: Visualizing Tribal Identity in Highland Yemen.” Visual Anthropology 11:55-102.

—2016. "Tribal Mediation and Empowered Women: Potential Contributions of Heritage to National Development in Yemen.” International Journal of Islamic Art 5 (2): 310-319.

Baldry, John. 1985. "The History of the Tihamah from 1800 to the Present." In Stone, Francine, ed., Studies on the Tihāmah: The report of the Tihämah expedition 1982 and related papers: 45-50, Burnt Mill: Longman.

—2015. The Idrisi Emirate of South East Arabia Giado (Libya), Jizan (Saudi Arabia) \& Sana'a (Yemen), 17671973. Istanbul: Isis Press.

Bang, Anne K. 1996. The Idrīsì State in 'Asīr 1906-1934: Politics, Religion and Personal Prestige as Statebuilding Factors in Early Twentieth-Century Arabia. Bergen: Center for Middle Eastern and Islamic Studies.

Behnstedt, Peter. 1987. Die Dialekte der Gegend von Şa'da (Nord-Jemen). Wiesbaden: Harrassowitz.

Blumi, Isa. 2009. "The Frontier as a Measure of Imperial Power: Local Limits to Empire in Yemen, 1872 to 1914." Proceedings of the British Academy 156:289-304. 
2010. Rethinking the Late Ottoman Empire: A Comparative Social and Political History of Albania and Yemen, 1878-1918. New York: Gorgias Press.

Brandt, Marieke. 2014. “The Irregulars of the Șa dah War: 'Colonel Shaykhs' and 'Tribal Militias' in Yemen's Hūthī Conflict (2004-2010).” In Helen Lackner, ed., Why Yemen Matters: A Society in Transition: 105-122, London: Saqi.

2017. Tribes and Politics in Yemen: A History of the Houthi Conflict. London/New York: Hurst/Oxford University Press.

Caton, Steven C. 1993. "Peaks of Yemen I Summon”: Poetry as Cultural Practice in a North Yemeni Tribe. Berkeley, Los Angeles: University of California Press.

Dostal, Walter, ed. 2006. Tribale Gesellschaften der südwestlichen Regionen des Königreiches Saudi Arabien (Sozialanthropologische Untersuchungen, Veröffentlichungen zur Sozialanthropologie Vol. 8), Vienna: Verlag der ÖAW.

Dresch, Paul. 1989. Tribes, Government, and History in Yemen. Oxford: Clarendon.

2000. A History of Modern Yemen. Cambridge: Cambridge University Press.

Gingrich, Andre. 1989. Der Agrarkalender der Munebbih: Eine ethnologische Studie zu sozialem Kontext und regionalem Vergleich eines tribalen Sternenkalenders in Südwestarabien. Post-doc. diss., University of Vienna.

— 1993. "Tribes and Rulers in Northern Yemen.” In Andre Gingrich, Sylvia Haas, Gabriele Paleczek and Thomas Fillitz, eds., Studies in Oriental Culture and History: Festschrift for Walter Dostal: 253-280. Frankfurt, New York, Vienna: Peter Lang.

2002. "Regen Gottes, Land der Ehre: Konzeptualisierungen von ,Natur' bei den Munebbih des Nordwestjemen." In Andre Gingrich and Elke Mader, eds., Metamorphosen der Natur: Sozialanthropologische Untersuchungen zum Verhältnis von Weltbild und natürlicher Umwelt: 143-159. Vienna, Cologne, Weimar: Böhlau.

— 2011. "Warriors of Honor, Warriors of Faith: Two historical male role models from south-western Arabia." In Maria Six-Hohenbalken and Nerina Weiss, eds., Violence Expressed: An Anthropological Approach: 37-54, Farnham: Ashgate.

2012. "Paradise Lost, or Paradise Regained? Conceptions and Ideologies of Himah as a Ritual Site in the Highlands of South-Western Arabia.” In Gabriela Kilianová, Christian Jahoda, Michaela Ferencová, eds., Ritual, Conflict and Consensus: Case Studies from Asia and Europe, Veröffentlichungen zur Sozialanthropologie 16:65-74, Vienna: Verlag der ÖAW.

2015. "Tribe." In James D. Wright, ed., International Encyclopedia of the Social \& Behavioral Sciences, $2^{\text {nd }}$ edition, 24: 645-647. Oxford: Elsevier.

Gingrich, Andre and Johann Heiss. 1986a. "A Note on Traditional Agricultural Tools in Şa da Province (with special reference to the ard)." In Proceedings of the Seminar for Arabian Studies 16:51-63.

1986b. Beiträge zur Ethnographie der Provinz Şa'da (Nordjemen): Aspekte der traditionellen materiellen Kultur in bäuerlichen Stammesgesellschaften (Veröffentlichungen der Ethnologischen Kommission No. 3). Vienna: Verlag der ÖAW.

Heiss, Johann. 1998. Tribale Selbstorganisation und Konfliktregelung: Der Norden des Jemen zur Zeit des ersten Imams (10. Jh.), doc. diss., University of Vienna.

2018. "Migrations and Federations: The origins of the tribal federation of Khawlān according to al-Hamdānī." The Medieval History Journal 21 (2): 365-379.

Philby, Harry St. J. B. 1952. Arabian Highlands. Ithaca: Cornell University Press.

Varisco, Daniel M. 1983. "Sayl and Ghayl: The Ecology of Water Allocation in Yemen.” Human Ecology 11:365-383.

— 2009. "Agriculture in al-Hamdān̄̄s Yemen: A Survey from Early Islamic Geographical Texts.” Journal of the Economic and Social History of the Orient 52 (3): 382-412.

- 2017. "Yemen's Tribal Idiom: An Ethno-Historical Survey of Genealogical Models.” Journal of Semitic Studies 62 (1): 217-241. 
Weir, Shelagh. 2007. A Tribal Order: Politics and Law in the Mountains of Yemen, Austin: University of Texas Press.

Wolf, Eric R. and John W. Cole. 1974. The Hidden Frontier: Ecology and Ethnicity in an Alpine Valley. New York: Academic Press. 



\title{
FROM BORDERING TO ORDERING: THE TRIBAL FACTOR IN MANAGING THE YEMENI-SAUDI BORDER
}

\author{
Lis a LenZ-Ayoub
}

\section{Introduction}

This chapter aims at a closer consideration of the different border management practices at the YemeniSaudi border and its transformation throughout the $20^{\text {th }}$ century and until today. Particular attention will be paid to the shifting importance of the local tribes in managing the border. The $21^{\text {st }}$ century has marked the beginning of major changes in the tasks of the border shaykhs (tribal leaders) and their tribes, who have been responsible for the guarding and administering of the border from its initial establishment in 1934. Increasing Saudi security concerns, as well as the conflicts raging in northern Yemen, have contributed to the successive formalization, institutionalization and militarization of the Yemeni-Saudi border management at the expense of the long-standing role of the local tribes. Today, with the conflict-induced eviction of many shaykhs from their territories, the traditional system of tribal border protection has collapsed.

By understanding the essence of border making as power strategy (Popescu 2012, 8), the chapter illustrates drastic power transformations in the securing of the Yemeni-Saudi border, shifting from relative tribal autonomy and responsibility, and close cooperation between tribe and state, towards the increasing exclusion of the border tribes from active bordering processes and practices. The theory of border studies has extensively addressed this phenomenon. In the 1990s, border studies faced a major paradigm shift that has led to the understanding of borders as processes or practices that can be produced by different actors on multiple levels. Newman and Paasi (1998) suggest that borders and their meanings are historically determined and thus, a focus should be put on how boundaries and their narratives of inclusion and exclusion are produced. Following this perspective, a debate on "bordering" (Van Houtum and Van Naerssen 2002) which takes account of the socially constructed character of borders as vantage points would be fruitful for further reflection. Borders are continually enacted, created and maintained by local "borderwork," the informal and formal labor of borderland residents. In this view, it becomes clear that local actors are not always passively subjected to borders and bordering processes from above; rather, they are enrolled and engaged in the active remaking of political and social borders (Rumford 2008; Lamb 2014). Border communities are often perceived as isolated, sometimes autonomous groups far away from the power center of a state. However, it will be shown that in specific regional and historical contexts, these communities can fulfill the function of an important cooperation partner for the central government and gain certain benefits from this collaboration. Especially when the influence and control of central authorities was considerably marginal at the margins of a territory and political power was rather concentrated on local or regional levels, central state powers considered the establishment of dependable and cooperative local networks an effective strategy to extend their state authority (Hignett 2008, 35). Strategic communities for the explicit purpose of defending the 
border either had to be created in the first place, or the central power had to co-opt already existing communities. This could not have been done without offering these communities a series of enticements or providing them with certain privileges in return for their cooperation ${ }^{1}$ (Hignett 2008, 50-51). The following case studies elucidate different forms of border management that reflect the three phases in the transformation of the Yemeni-Saudi border management.

In the first case study, Gavrilis (2008) explores the Greek-Ottoman border throughout the $19^{\text {th }}$ century. The successful management of this border originated from the fact that both state authorities had more or less completely delegated the border administration to local authorities. In particular, these local authorities, who were instructed to administer and secure the border, consisted of a group of former bandits, mercenaries and domestic police units. For the first decade after the demarcation of the GreekOttoman border, the border administration of the two states depended to a considerable extent on a local level and was outsourced from the central governments' agendas and responsibilities. The border guard institutions on both sides collaboratively developed innovative policing tactics such as the coordination of border patrols or regular meetings in order to effectively guard the common border.

In the second ethnographic sample, Reeves (2014) focuses on the recent "borderwork" that takes place in the borderlands between Kyrgyzstan and Tajikistan. The majority of the border guard members are single men who were raised up in a social system strongly based on age hierarchy. Economic contexts given, border guards establish manifold social relationships with the inhabitants of the border region in which they are deployed. Encounters among the border villagers and the border guards include receiving gifts such as tobacco or gasoline, transportation services between the village and the border post and the exchange of news and gossip. Reeves highlights the uncertain and negotiable functions and associations with the act of border guarding. Apparently, border guards are often suspected of and associated with corruption. Similarly, the border guard's authority is perceived as frangible and often becomes the target of subversive attempts (Reeves 2014, 175). Border guards are bearers of the variable permeability of the borders they are monitoring. They are expected to know who and what can transcend the border without further examination. Social customs, rather than border authorities, often determine who is able to cross through unchecked. In practice, this requires the ability to memorize a high number of names, persons, vehicles and their connected social status (ibid, 176).

The third case study by Maurer and Sälter (2011) exemplifies a central state-controlled border management that totally excludes local border communities. From the 1950s, the East German Border Guard was not only responsible for preventing citizens from fleeing to West Germany but was also expected to serve as an initial front-line defense in case of war. The Ministry for State Security (the "Stasi") surveilled and controlled the distribution of conscripts. Family links to West Germany usually caused the deployment of the conscript far from the actual border (Maurer and Sälter 2011, 26).

What these border case studies show is an essential differentiation between three distinct stages of border management. The first phase embraces managing a border relatively autonomously on a local level. This form includes close cooperation between local border communities and the central government as well as the provision of incentives such as certain privileges to the border residents in return for their

E.g. economic privileges such as land, hunting and fishing rights that were granted to ethnic or social groups in the borderlands, but also important financial subsidies in money or grain as well as the yielding of considerable degrees of domestic autonomy and self-government. 
services at the borders. In a second stage, professional border guards supplied by the state successively replace local border guards and centralize certain border practices such as the administration or crossborder movements. The third level comprises the efforts by the state to fully control its national borders through centrally regulated border practices such as the deployment of trained soldiers without any social relationships to the border area. These three different stages roughly correspond to the development of Yemeni-Saudi border management, which will be examined in more detail below.

\section{The Yemeni-Saudi Border Region}

The Yemeni-Saudi border region surrounds a border spanning more than 1,800 kilometers from the Red Sea to the border triangle with Oman encompassing strategically and economically significant land and maritime territories between Northern Yemen and Southern Saudi Arabia. For an extended period of time, large stretches of the international border remained undefined and unfixed due to the active involvement of the borderland tribes within both countries in establishing and securing the border. Only in 2000, did the Treaty of Jeddah permanently define the exact location of the common borderline. On the Yemeni side, the governorates of Hajjah, Șa dah, al-Jawf and Haḍramawt directly adjoin the international border, neighboring the Saudi provinces of 'Asīr, Jīzān, Najrān and al-Sharqiyah. The present study focuses on the western part of the disputed boundary mainly for two reasons. Firstly, the northernmost Yemeni border province of Șa dah is far more populated than the eastern border regions, and secondly, the tribal societies of the western border region (i.e. mainly the eight tribes of the Khawlān bin 'Āmir confederation as well as the Bakīlì tribes Wā'ilah and Dahm) have been studied extensively in recent decades (see, for example, Gingrich 1993; Lichtenthäler 2003; Weir 2007; Brandt 2017). This provides access to a research area that has to be studied at a distance due to the insecure and unstable political situation on the ground ${ }^{2}$.

The majority of Șa 'dah's population is tribal and associated with the confederations of Khawlān bin 'Āmir and Bakīl. The confederation of Khawlān bin 'Āmir subdivides into eight main tribes (five of them located in Yemen), which further subdivide into moieties and subtribes or segments. Given the historically weak influence of the Yemeni state in its northern peripheries, the members of the tribal borderland communities have, for long periods of history, lived and acted with a relatively high status of autonomy. This was partly based on their economic independence due to farming and livestock supplemented by extensive regional trading. Historically, the region of Șa 'dah was closely linked by official and unofficial commercial activities along ancient trade routes with the areas that are today the Saudi provinces of 'Asīr, Jīzān and Najrān. These trading activities were dominated by tribal groups and families who established extensive trade networks across the border. Socially, qabyalah provided a traditional and yet locally diverse system of tribal leadership and customary law as well as social structure, norms and rules (Adra 1982). The tribal societies along the common border with Saudi Arabia have historically entered into very different relationships with overlords and states - be it their relationships with the former religious elite ${ }^{3}$ in imamic Yemen or the Republic after 1962 (Gingrich

The present study is based on literature research supplemented by numerous written online interviews with local informants, namely influential shaykhs from the border region, via WhatsApp.

3 For over a millennium, parts of Northern Yemen were ruled by an imamate established by Zaydi imams in the $9^{\text {th }}$ century in Yemen. The sādah (sg. sayyid) claimed legitimate rule by their descent from the Prophet Muhammad through the line of the Prophet's daughter Fāṭimah and his son-in-law 'Alī Ibn Abū Ṭālib (see Dresch 2000, 15). 
1993). Before the September Revolution of 1962, which led to the overthrow of the last imam and the establishment of the Yemeni Republic, the imams depended on the loyalty of the tribal elites to provide military strength for their governments. They therefore pursued a precarious policy of cooperation and coercion vis-à-vis the tribes, which optionally consisted of patronage, military subjugation, and/or hostage taking (Dresch 1991, 257; Weir 2007, 287ff).

The initial establishment of the Yemeni-Saudi border in 1934 bisected the Khawlān bin 'Āmir and parts of the Bakīl confederation. The territories of three tribes of the Khawlān bin 'Āmir confederation, Fayfā', Banī Mālik and Balghāzī, are located in Saudi Arabia due to Yemen's cession of land to the Saudi kingdom in 1934. The territories of the tribes of Munabbih, Rāziḥ, Khawlān, Jumā'ah and Sahār are located on Yemeni land (Gingrich 1993, 258). In addition to the division on the confederation level, the tribal territories of the Jumā' ah and the Bakīlì Wā'ilah tribe have been bisected by the border on a subtribal level (Brandt 2017, 27). However, strong tribal links, facilitated through descent, kinship and marriage relations, remained vital across the international border (ibid, 77).

\section{The Introduction of the Border}

The initial establishment of the international border between Yemen and Saudi Arabia after the SaudiYemeni War of 1934 was part of the peace negotiations between the two countries competing over the provinces of Najrān, 'Asīr, and Jīzān. The post-war Treaty of Țā' if first officially defined the boundary between the Yemeni imamate and the kingdom of Saudi Arabia on the map along the so-called "TTầ' if Line" 'between the Red Sea coast to the west and Jabal al-Tha'r near Najrān city to the east. The division was implemented by an international border demarcation committee headed by Harry St. John Philby in which some shaykhs of the border tribes were actively involved. However, parts of the central mountainous section of the borderline remained undefined because the committee could not access them due to tribal conflicts (Philby 1952; al-Enazy 2005). The exact course of the Ṭâ' if Line, therefore, was of vital importance for the central governments of both Yemen and Saudi Arabia and the local tribes. In practice, however, after its initial establishment in 1934, the border remained invisible for the local border population since moving across the border for visiting relatives, herding cattle and engaging in cross-border trade were everyday practices and were legally guaranteed in the stipulations of the border treaty.

The period after the Saudi-Yemeni War marked the beginning of a close relationship between the Saudi government and the Yemeni borderland tribes. From 1934 onwards, the Saudi kingdom pursued a policy of alliance and patronage in the common borderlands aiming at ensuring the loyalty of the Yemeni border tribes. Through the integration of Yemeni borderland shaykhs into Saudi patronage networks, the Saudi kingdom aimed at securing the stability of the new controversial border with the support of its local tribal aides (Brandt 2017, 78). As a legal basis for Saudi Arabia's political strategy, special and unusual provisions regarding the rights of the borderland tribes were included in the Treaty of Țầ if and its appendices. Appendix 3, Article 1 (1936) granted borderland residents the right to cross the border through certain checkpoints without restrictions, whereas other Yemeni citizens were obliged to enter Saudi Arabia with regular passports and visas. From the tribal perspective, the Saudi cooperation strategy and the establishment of the international border was highly beneficial as long as their legal rights to cross the border were guaranteed (Brandt 2017, 79). 
Competing over Tribal Support

The TTâ' if Treaty of 1934 was concluded as a temporary settlement that had to be renewed every 20 lunar years. These renewals took place in 1953 and 1973 after periods of severe tensions and deep political disagreement between Yemen and Saudi Arabia. Moreover, the Saudi kingdom's vulnerability towards violence and instability in Yemen became evident during the 1962 Yemeni revolution and the ensuing civil war that led to the abolition of the imamate and the establishment of the Yemeni republic. Saudi Arabia's initial considerations of the Yemeni war as a domestic matter changed when Egyptian troops targeted Saudi border towns in air raids in November 1962. During the civil war, the established patronage networks with the borderland tribes proved highly beneficial for the Saudi government because loyal border tribes functioned as buffer zones between Saudi Arabia on the one side, and Yemen's republicans and its Egyptian allies on the other (Badeeb 1986, 51). After the civil war, Șa 'dah's tribal leaders continued to benefit from Saudi subsidies that contributed to the image of the Saudi kingdom as supporting and protecting the interests of Yemeni borderland tribes. Its major financial concessions to the borderland shaykhs granted Saudi Arabia an influential stake in Yemen's north and solidified a secure boundary. From a tribal perspective, Saudi subsidies enabled border shaykhs to extend their local power and to acquire additional sources of income and influence (Brandt 2017, 83).

The 1960's civil war marked the beginning of a new political era in Yemen that had repercussions on Yemeni and Saudi border politics concerning their common, still unsettled boundary. The development that set in after the fall of the Yemeni imamate resembled the situation in many other regions of the world. With the consolidation of the Yemeni nation state and the rise of a national awareness, the Saudi government reinforced its central objective of securing the loyalty and cooperation of the Yemeni borderland shaykhs and their tribal allies for the sake of securing and stabilizing the Yemeni-Saudi border. The fledgling and vulnerable Yemen Arab Republic (YAR), on the other hand, also attempted to patronize the northern tribes for its own interests. For some of the border shaykhs, the newly established government of the YAR offered the opportunity for extending their power and influence on the national level. In the YAR, for the first time ever, tribal leaders were incorporated in the government. The resulting relationship of mutual loyalty between the state and some of the border shaykhs and their tribes enabled the government to gain influence in the tribal peripheries of the country (Brandt 2017, 57). Against this background, local tribal leaders of the border regions such as the senior shaykh of the Munabbih tribe during the 1970s, were assigned to act on behalf of the republican state. The northern and western borders of Munabbih's tribal territory were congruent with the - in parts still undefined - international border with Saudi Arabia, and the republican government authorized the Munabbih to monitor and secure these parts of the international border as an "auxiliary police force" (Gingrich 2011, 43). Competition over tribal support and loyalty by the Yemeni and the Saudi governments has led to the engagement of some shaykhs in double-dealings, receiving lucrative subsidies from both sides of the border (Brandt 2017, 83).

\section{Determining the Boundary}

The Treaty of Jeddah in 2000 marked the next step in the development that led from a Yemeni-Saudi border policy focusing on tribal cooperation and patronage networks towards a border management strategy aiming at more strictly guarding and monitoring the national borders with Yemen. Under the 
government of 'Alī 'Abd Allāh Șālih, ${ }^{4}$ the Treaty of Jeddah was signed in 2000. The Jeddah Treaty integrated the regulations and all appendices of the Țầ if Treaty altering the terms as final, permanent and non-renewable. In addition, despite the resistance of the opposition parties, the Saalih government abandoned Yemen's former territorial claims to the regions of 'Asīr, Jīzān, and Najrān. The three contested regions permanently belong to the Saudi kingdom and formerly undefined segments of the land and the sea border are now defined by their exact location in geographical coordinates rather than by ambiguous tribal affiliations. Still, the provisions of the Treaty of Jeddah, like the Treaty of Țà' if, grant the borderland residents the right to cross the border without restrictions through designated border checkpoints (al-Enazy 2002, 70). Nevertheless, the final demarcation of the boundary obliterated the former active involvement and participation of the border tribes in the political debates and negotiations on the border. The Saudi argument for justifying this step was the need to improve the security and stability situation (Brandt 2017, 86-87). After the signing of the Treaty of Jeddah, which permanently demarcated and fixed the previously largely undefined border, the prior informal cooperation between the Saudi and the Yemeni government and some of the borderland tribes became formally institutionalized.

\section{The Institution of the Yemeni-Saudi Border Guard}

In 2003 the joint Yemeni-Saudi Border Guard (haras al-hudūd) was established, a regular army unit consisting of soldiers with a local background positioned along the international boundary, particularly in the mountainous regions of the Țâ' if Line border segment. The main driver for the establishment of the joint Border Guard institution and the fostering of mutual cooperation between Yemen and Saudi Arabia was the high increase of illicit cross-border movements such as the smuggling of weapons, explosives, and drugs as well as the illegal immigration to the Saudi kingdom. According to the website of the Saudi Ministry of Interior, King 'Abd al- 'Azīz laid the cornerstone for the present Border Guard already in 1913 by establishing patrols and centers for guarding the eastern coast. Concentrating predominantly on watching and controlling the maritime coasts of the Saudi state, the former "Directorate of Coast Guard" was transformed into the armed "General Directorate of border armed-force, and coasts and seaports guard" in the early 1960s, which in the early 90s became the "General Directorate of Border Guard". The Border Guard is supposed to maintain the security of the kingdom's sea and land borders. It is subdivided into nine different key departments, among them the separated subsidiaries of 'Asīr, Jīzān and Najrān. All of them consist of different sectors guarding a stipulated length of kilometers of the border demarcation. These sectors also include several centers. According to the website, the Sharürah sector is the biggest sector guarding the border with Yemen, which is responsible for guarding about $1013 \mathrm{~km}$ on land, and it includes 17 centers (MOI 2018). Whereas the Saudi Ministry of Interior provides an elaborate website for the Saudi Border Guard, ${ }^{5}$ there is no equivalent for the Yemeni Border Guard. According to one of my informants, who was an officer in the Yemeni Border Guard for five years, the main tasks of the Yemeni Border Guard encompass securing the boundary, monitoring transgressors and the controlling of smugglers. He states that the Yemeni Border Guard consists of 30,000 members deployed among numerous units along the Yemeni-Saudi and the Yemeni-Omani borders.

$4 \quad$ From 1978 'Alī 'Abd Allāh Șāliḥ was president of the Yemen Arab Republic (North Yemen). He became Yemen's first president after unification in 1990. In February 2012 he was succeeded by 'Abd Rabbuh Manșūr Hādī.

5 The official website of the Saudi Border Guard publishes current reports of people and goods that have been prevented from entering the Saudi kingdom. They also stated there that 52 women joined a security inspection training course in 2017. 


\section{The Fortification of the Border}

Despite the overall progress of the joint Yemeni-Saudi Border Guard institution in curtailing illegal border-crossings, it was difficult for both countries to fully control their joint borders due to the rough terrain (Brandt 2017, 84). More importantly, the weakness of the Yemeni state meant that the chances of success for a joint border management were minimal (Rossiter 2017, 32). In order to control the threats deriving from the permeable border, the two national governments took certain joint and individual steps in the years after the signing of the Jeddah Treaty such as constructing watchtowers along the border, establishing joint patrols, increasing security coordination and exchanging information on contraband and border-crossers (al-Rammah and Awass 2009, 6). Thereby, the two governments successively withdrew the task of border control from the borderland shaykhs and put the more centralized institution of the Yemeni-Saudi Border Guard in charge of controlling the border. Meetings between the Yemeni and Saudi authorities were held regularly, such as the periodical meetings of the Yemeni-Saudi Coordination Council or those of the border officials. The border authorities consisted of three different social levels, comprising the Yemeni-Saudi joint committee (whose meetings are presided over by the Yemeni and Saudi interior ministers), and the second and third-rank joint committee. The latter is made up of representatives of the border guard bodies of the two countries. Saudi Arabia, for its part, installed permanent watchtowers, built up its border guard units and intensified the patrols, and laid barbed wire along some parts of the border. At a cost of $\$ 8$ billion, electronic equipment has been installed, such as thermal cameras which detect living or moving objects at a distance of 5 kilometers (al-Rammah and Awass 2009, 6). These joint and individual measures curbed - according to the Saudi government - all kinds of smuggling operations and the movements of illegal border-crossers on both sides (al-Rammah and Awass 2009, 8). The increasing regulation and securing of the border negatively affected the constant trade relationships that had historically kept the Șa 'dah region flourishing, thereby imposing major challenges for the local population in pursuing their commercial activities and interests (Blumi 2011, 111).

As a result of Saudi Arabia's increased perception of the cross-border movements as a threat to Saudi internal affairs and security, the kingdom started to complete the demarcation of the border as concluded in the Treaty of Jeddah with the support of international companies. As a further step, the kingdom also launched the construction of a border fortification which further induced the physical implementation of the boundary. This endeavor aimed at preventing alleged threats identified by the Saudi government such as a flow of economic refugees, al-Qaeda fighters, smuggled weapons and drugs as well as the potential spillover of political events inside Yemen from entering the Saudi kingdom. The physical implementation of border fortifications starting in 2003 marked another turning point in Saudi border policy. The Saudi intention was to fix the long undefined and unimplemented border, which had been open for borderland residents' crossings and partly depended on tribal territorial negotiations. With this controversial measure, Saudi Arabia provoked some of the borderland tribes such as the Wa' ilah, who reacted with fierce resistance and sabotage of the border fortification works. In the Treaty of Țâ' if and its border regulations, parts of traditional Wa' ilah territory were assigned to the Yām tribe. Consequently, members of the Wā' ilah tribe are still fighting against the demarcation of the border right up until today. The Wầ ilah consider the provisions of the Treaty of Jeddah, including the Saudi border fortification project, a violation of the tribes' legal rights to cross the border in exchange for their loyalty to the Saudi kingdom (al-Enazy 2005, 14; Brandt 2017, 77-80).

Since the eruption of armed conflict in the border region in 2004, the Yemeni regime has increasingly lost control of its northwestern periphery. The emerging power vacuum led to the expansion of the 
Hūthī movement in Yemen's north. Many of the important tribal leaders in Șa 'dah, and especially from the border region, were displaced and fled to Saudi Arabia. The former powerful positions of Șa 'dah's tribal leaders generated through close cooperation with the Yemeni and the Saudi states were weakened in the wake of the Hiuthī movement's growth. Its attraction to those who felt economically, politically and religiously marginalized has led to internal tribal conflicts and the dissociation of many formerly influential shaykhs from their tribes (Brandt 2017, 37). The Saudi kingdom, having invested in the establishment of cooperation with these shaykhs since the initial introduction of the border, welcomed them with open arms in Saudi Arabia, formally continuing their policy of co-option. Nevertheless, the expulsion of Riyadh's tribal cooperation partners from the border areas had a major impact on Saudi Arabia's border policy, as it led to the weakening, if not elimination, of those cooperation and securing practices with the borderland tribes which had been established and maintained by Saudi Arabia for decades (Brandt 2017, 96).

\section{Recent Developments at the Yemeni-Saudi Border}

Since the seizing of power by the Anșār Allāh or Ḥūthī movement, the Yemeni Border Guard has split up into several political fractions. The pro-Hādī Border Guard unit to whom my informant belonged was established in 2014 and is made up of 1500 men. The unit's 15 checkpoints are located on the Saudi side of the international border since the Yemeni territories of the border area have been occupied by the Hūthī forces. These Border Guard units, loyal to Hādī, were therefore dislocated from Yemeni territory. Hence, the fracturing of Yemen's political landscape is mirrored in the current re-organization of the Border Guard.

Two newspaper articles from the Middle East Eye highlight the current precarious situation and transnational transformation of the Yemeni-Saudi border conflict in the present time. The first one from August 2017 points to the fact that thousands of poorly trained Yemenis were recruited by the Saudi government to fight against the Hūthī rebels instead of their own soldiers. Trained within only a few weeks, the Yemeni mercenaries, who were predominantly recruited from Yemeni provinces in the south that are controlled by pro-Hādī forces and the Saudi-led coalition, are deployed into Saudi-funded border defense regiments that are staffed almost exclusively by Yemenis. Their average wage is up to $\$ 800$ per month, a significantly higher amount of money than can be earned from fighting in local battles. The wages for fighters in Yemen, at $\$ 130$ per month, are less than a quarter of those fighting on the Saudi side (MEE 2017a). Apart from Yemenis, most other troops fighting with the Saudi-led coalition against the Hūthīs are foreigners, among them many fighters from Egypt and Pakistan, but also from Latin American countries such as Columbia, Panama, El Salvador and Chile. Here, it becomes evident that not only in the past but also in the current Yemeni-Saudi border dispute, the motivations for guarding and administering the border from a tribal as well as from a state point of view depended greatly on, amongst others, economic reasons. In December 2017, the second newspaper article reported that hundreds of Yemeni mercenaries fighting for Saudi Arabia had protested peacefully in reaction to the non-disbursement of their salaries. According to sources, the soldiers were then paid $\$ 400$, they were told that they were no longer needed and were sent back to Ma'rib in Yemen where they had received their training months earlier (MEE 2017b). Inconsistent with these articles, sources from among the Yemeni Border Guard indicate that Yemeni citizens neither fight for the Saudi haras al-hudūd nor for the general Saudi army. The Yemeni and the Saudi Border Guard cooperate and work closely together as one joint institution but each national Border Guard subordinates to its national government. 
As has been shown, shifts in Saudi Arabia's border policy resulted in the successive marginalization of Yemeni border tribes in managing and guarding the border. Responsibilities and well-established cooperation between the Saudi kingdom and the Yemeni border tribes have gradually been weakened and taken over by a state-led institution that hired mercenaries from different countries as border guards. It is worth noting that the online application form for a position in the Saudi Border Guard requires - among other information - detailed indications on the tribal background, including confederation, tribe, tribal section, and representative persons of the applicant (MOI 2018), which shows that the Saudi government is well aware of the importance of tribal identity and belonging within the border management. Historically the kingdom has always recognized the tribal background of its border guards and their relationship to the borderland residents as an important factor in the general border management. In recent years, however, Saudi Arabia seems to steer away from local tribal border management because it perceives permeable borders, regularly crossed by people, goods and contraband as threats. To prevent these threats, local border management has been replaced by a professional, highly hierarchized border guard consisting of soldiers and officers without links to the local tribal population.

\section{Conclusion}

Managing and securing the Yemeni-Saudi border has undergone profound transformations since the first establishment of the border in the Treaty of Ța $\bar{a}$ if in 1934. During the decades after the initial border demarcation, many Yemeni shaykhs and their affiliated tribes from the northern provinces of Șa dah and al-Jawf were responsible for the security and administration of the Yemeni-Saudi border. In return, they received substantial financial support and rights from Saudi Arabia in order to carry out their tasks. Other examples highlight the widespread practice and use of border communities as border guards e.g. at the Greek-Ottoman border (Gavrilis 2008). The rough physical conditions in the Yemeni-Saudi border region, especially in the mountainous border segments were another reason to rely on border guards who are familiar with the local terrain and its people. Moreover, the Yemeni border shaykhs had a vital interest in monitoring and administering the international border since segments were identical with tribal territorial margins that had yet to be renegotiated. In the course of the permanent and definite determination of the border in the Treaty of Jeddah in 2000, the duty of securing the border was successively transferred from the tribes to a central state institution, consisting of a joint Yemeni-Saudi Border Guard. The formalization of border management practices tends to follow with strong militarization of border guards in case of danger and perceived threats. Like the East German Border Guards in the 1950s as well as the Chods in the Kingdom of Bohemia (Hignett 2008, 47), the joint Yemeni-Saudi Border Guard, too, with the beginning of the $21^{\text {st }}$ century has performed a double task. Their primary function of preventing fugitives and illicit trade from crossing the border has been reshaped into serving as an initial front-line defense. The traditional practice of local border management in Yemen has not continued further due to the splitting up and re-formation of several Yemeni border guard units which recruited soldiers from all over the country. Thereby, and through Saudi Arabia's announcement of the construction of a border fence, the special rights and privileges of the Yemeni border tribes that were stipulated in the official border agreements between the two states have been curtailed. For them, the possibility of actively negotiating and adapting the Yemeni-Saudi border according to tribal resolutions and local agreements was gradually diminished and impeded. With the coming into power of the so-called Hüthī rebels in Yemen, the pro-Saudi border shaykhs were expelled from their territories in the North of the country and many of them have taken refuge in Saudi 
Arabia. In the course of the internal political conflicts, the official institution of the Yemeni Border Guard has split up and reformed into several different factions. Hence, not only the traditional locally administered but also the centrally organized system of securing the border in Yemen has collapsed, leaving the border region more contested than ever.

Throughout the $20^{\text {th }}$ century, Yemen's tribal border communities successively lost their central and active role in guarding the Yemeni-Saudi border. With a series of measures, and in order to implement and protect its porous border, Saudi Arabia has deprived its former tribal cooperation partners of their traditional task as loyal but semi-independent local border guards. As a result, the active "borderwork" of the border shaykhs and their tribes has been curtailed. The former bordering processes of Yemen's tribal border communities that implied their active participation in the act of controlling, negotiating, managing and securing the international border, have been transformed into practices determined, limited and strictly regulated by the states.

\section{References}

Adra, Najwa. 1982. Qabyala: The Tribal Concept in the Central Highlands of the Yemen Arab Republic. PhD thesis. Philadelphia: Temple University.

Badeeb, Saeed M. 1986. The Saudi-Egyptian Conflict Over North Yemen, 1962-1970. Westview Press, Boulder, Co.

Brandt, Marieke. 2017. Tribes and Politics in Yemen: A History of the Houthi Conflict. London/New York: Hurst/ Oxford University Press.

Blumi, Isa. 2011. Chaos in Yemen: societal collapse and the new authoritarianism. London: Routledge.

Dresch, Paul. 1991. "Imams and Tribes: The Writing and Acting of History in Upper Yemen". In Tribes and State Formation in the Middle East edited by Philip S. Khoury \& Joseph Kostiner, 252-287. Berkeley: University of California Press.

2000. A History of Modern Yemen. Cambridge: Cambridge University Press.

Al-Enazy, Askar Halwan. 2002. "The International Boundary Treaty (Treaty of Jeddah) Concluded between the Kingdom of Saudi Arabia and the Yemeni Republic on June 12, 2000.” The American Journal of International Law 96 (1): 161-173.

2005. The Long Road from Taif to Jeddah: Resolution of a Saudi-Yemeni Boundary Dispute. Emirates Center for Strategic Studies and Research.

Gavrilis, George. 2008. "The Greek-Ottoman Boundary as Institution, Locality, and Process, 1832-1882." American Behavioral Scientist 51 (10): 1516-1537. http://journals-sagepub-com.uaccess.univie.ac.at/doi/ abs/10.1177/0002764208316353.

Gingrich, Andre. 1993. "Tribes and Rulers in Northern Yemen." In Studies in Oriental Culture and History: Festschrift für Walter Dostal edited by Andre Gingrich et al., 253-280. Frankfurt am Main: Lang.

— 2011. "Warriors of Honour, Warriors of Faith: Two Historical Male Role Models from South-Western Arabia." In Violence Expressed: An Anthropological Approach edited by Marianne Six-Hohenbalken and Nerina Weiss, 37-54. Farnham: Ashgate.

Gingrich, Andre, and Johann Heiss. 1986. Beiträge zur Ethnographie der Provinz Șa 'da (Nordjemen). Vienna: Verlag der ÖAW.

Hignett, Kelly. 2008. "Co-option or Criminalization? The State, Border Communities and Crime in Early Modern Europe." Global Crime 9 (1/2): 35-51.

Houtum, Henk Van, and Ton Van Naerrsen. 2002. "Bordering, Ordering and Othering." Journal of Economic and Social Geography 93 (2): 125-136. 
Maurer, Jochen, and Gerhard Sälter. 2011. "The Double Task of the East German Border Guards: Policing the Border and Military Functions." German Politics and Society 29 (2): 23-39.

MOI. 2018. Ministry of Interior, Kingdom of Saudi Arabia, official Website of the Border Guard. https://www. moi.gov.sa/wps/portal/Home/sectors/borderguards/contents/!ut/p/z1/rVPLcoIwFN37FWxcZhJIIHSZMhXwMR1rUciGgYBIp4Ai1 fbvG9RFXQjt2CxucjPnvk5OIB8oymAAfbnJw09z5UBeRoc8i5q8KqN36MOAGyFyCXFUok3MkaUjNp8hR18fsa1RuDoBLJs5hE4RMqe2jlzmeC8Pc4wRw5B3xE_0Szy6sR j6ZfxtAO_ufwk55KJsts0GBnFVJ2mtZB9RneyH6OyePSWqh6hMj_uzla7Y5Ie0BWVhexOqJ1A1oCGVxmFUt2m3Ik9gkGCSUF3HIMYiBSSO1iBeCwPQhOhCPBgoJuKE3h9bOKc327Vwz7hyHt7N5rifT34NQcwcIcbw0nHoXHs21Qug68n7ulhIfoLOUV0Drg55eoReWdWFFOLij4Q6qK8CvrNCd3pG7kw_71 Ou_Jr5227HmdRvVTbpZwP9_xTwtvA8rzBxAfyvhQtsKzZnT1jPinC2_wZZBroP/dz/d5/L2dBISEvZ0FBIS9nQSEh/.

Newman, David, and Anssi Paasi. 1998. "Fences and Neighbours in the Postmodern World: Boundary Narratives in Political Geography." Progress in Human Geography 22 (2): 186-207.

MEE. 2017a. N.N. "Yemeni mercenaries fight and die to protect Saudi border". Middle East Eye, 4 August 2017. http://www.middleeasteye.net/news/yemenis-fight-saudi-arabia-s-war-return-pennies-1458536939.

MEE. 2017b. N.N. "The 'absurd' war: How Riyadh sacked the Yemeni fighters defending its border." Middle East Eye, 21 December 2017. http:/www.middleeasteye.net/news/absurd-war-how-riyadh-sacked-yemenimercenaries-defending-saudi-arabia-210870852.

Lamb, Vanessa. 2014. "'Where is the Border?' Villagers, Environmental Consultants and the 'Work' of the ThaiBurma Border." Political Geography 40: 1-12.

Lichtenthäler, Gerhard. 2003. Political Ecology and the Role of Water: Environment, Society and Economy in Northern Yemen, Aldershot: Ashgate.

Philby, Harry St. John Bridger. 1952. Arabian Highlands. New York: Da Capo Press.

Popescu, Gabriel. 2012. Bordering and Ordering the Twenty-first Century: Understanding Borders. Plymouth, UK: Rowman \& Littlefield Publishers.

al-Rammah, Khalid A., and Aish A. Awass. 2009. Yemeni-Saudi Experience of Joint Border Management: A Paper to be Presented to Mass Destruction Weapons and Border Security Group. Conference of the Strategic Research Centers in NESA: Sheba Center for Strategic Studies.

Reeves, Madeleine. 2014. Border Work: Spatial Lives of the State in Rural Central Asia. Ithaca, London: Cornell University Press.

Rumford, Chris. 2008. "Introduction: Citizens and Borderwork in Europe.” Space and Polity 12 (1): 1-12. http:// dx.doi.org/10.1080/13562570801969333.

Rossiter, Ash. 2017. "The Yemeni-Saudi Border: From Boundary to Frontline". In Yemen and the Gulf States: The Making of a Crisis edited by Helen Lackner and Daniel Martin Varisco, 29-44. Berlin: Gerlach Press.

Weir, Shelagh. 2007. A Tribal Order: Politics and Law in the Mountains of Yemen. Austin: University of Texas Press. 



\section{AL-MAWADDAH AL-KHĀLIDAH? \\ THE HŪTHĪ MOVEMENT AND THE IDEA OF THE RULE OF THE \\ $A H L A L-B A Y T$ IN YEMEN'S TRIBAL SOCIETY}

ALEXANDER WEISSENBURGER

Introduction

The term "mawaddah," literally meaning "love" or "affection," has been used in Upper Yemen for centuries, optimistically describing specifically the feelings of love and loyalty the tribal population supposedly harbored for the religious ruling elite (Serjeant 1982, 23-25). This religious elite was mainly comprised of the sädah (sg. sayyid) or ahl al-bayt, ${ }^{1}$ the descendants of Muhammad through his daughter Fāṭimah and his nephew and son-in-law, 'Alī. Upper Yemen is the home of Zaydism, a denomination of Shi ite Islam, which is characterized by the role of political leadership it assigns to the ahl al-bayt. For the better part of a millennium, between the end of the $10^{\text {th }}$ and the middle of the $20^{\text {th, }}$ century, Upper Yemen has thus, at least nominally, been ruled by an imam from among the ahl al-bayt, while the religious and administrative elite was to a large degree constituted by the ahl al-bayt. While the existence of a specific term to denote the tie between this elite and the general population points to the immense importance of this relationship for Yemeni society, in reality the attitude of the tribal population towards its religious rulers was never as harmonious as the phrase makes it out to be. With the end of the imamate and the consequent decline of Zaydi scholarship, however, the issue lost its significance. Only with the revival of Zaydism in the 1990s and especially with the appearance of the Hūthī movement a decade later, did the question of religious leadership gain relevancy again, albeit in an entirely different conceptual setting.

Especially in the context of the emergence of the Hūthīs, a Zaydī religio-political movement founded in the early 2000s, the issue of the imamate gained relevancy again. While much of the Hüthī movement's rhetoric revolves around typical "third-worldist" or anti-imperialist interpretations of Yemen's political situation, there is an increasing amount of effort spent on the question of religious rule in the context of Yemen's tribal society. The earliest ideological statements of the group, the speeches of its founder, Husayn al-Ḥuthī, himself a member of the ahl al-bayt, address the issue only briefly. While legitimizing the ahl al-bayt's claim to the right to leadership in religious terms, he does not really attempt to connect these claims to the societal realities of Upper Yemen, which were, and still are, characterized by tribalism. With the political success of the movement in the wake of the Arab Spring, the movement now engages with the problem in a more concrete manner, trying to reinterpret the relationship between the tribes and the ahl al-bayt in a way conducive to their political aspirations.

In the remainder of the chapter, these two terms will be used interchangeably. 
This chapter will first show how the role of the ahl al-bayt in Yemen's society was fundamentally altered by the foundation of the Yemeni Republic in 1962. With the abolition of religious rule and the introduction of new markers of Yemeni identity, the ahl al-bayt lost not only their religious and political position in society, they, and by extension also Zaydism, in a sense also ceased to be Yemeni. While it has to be acknowledged that reality is never as clear cut as presented in a theoretical discussion, and Zaydism and the ahl al-bayt in reality remained an integral part of Yemeni society, the implications of the ahl al-bayt's conceptually altered status are diametrically opposed to the claims to legitimate religio-political leadership advanced by the Zaydī actors such as the Hūthī movement. This chapter will thus use these conceptual considerations in order to analyze the Hūthī movement's calls for the reintroduction of religious rule.

\section{Religious Rule in Yemen's Tribal Society}

The use of the concept of tribes has been strongly criticized by scholars pointing to its misuse by colonial powers from the $17^{\text {th }}$ century onwards. The term is therefore seen by many as negatively charged and frequently replaced in academic discourse by terms like "ethnic group" or "indigenous people" (Gingrich 2015, 645). Upper Yemen, as well as most parts of the Arabian Peninsula, however, were never colonized by Western powers. Tribes in Yemen and large parts of the Arabian Peninsula in general are not a selfserving colonial construction, but have been part of social reality for at least one and a half millennia. ${ }^{2}$ The majority of Yemenis self-identify as tribal ${ }^{3}$ and the term "qabilah" is found repeatedly in Yemeni historiography of the last centuries, reflecting the indigenous nature of the concept. The same holds true for the segments (such as sha 'b, qabïlah, 'imärah, bațn) of Yemen's tribal society (Varisco 2017).

Tribes and their subdivisions are each mainly bound together by mutual ties of solidarity based on shared notions of common ancestry. ${ }^{4}$ Each of these segments, down to the household, is an independent unit (Serjeant 1982,12), which allows them to "mobilize quickly and effectively to accomplish certain tasks" (Adra 2016, 1185). Tribes and their segments are therefore cooperative entities tasked with the accomplishment of mutually shared goals. Whether society in northern Yemen persists in a perpetual state of anarchy in which tribes and their segments only come into existence in order to protect their honor (sharaf) from infringements from other conceptually equal units as Dresch $(1984,35)$ writes in one of his earlier articles may, however, be contested. The performative qualities of tribal dance (Adra 1982, 60), the collective recitation of tribal poetry (Caton 1990), as well as guest meals (Gingrich 1989, 143) also serve to evoke communal cohesion, as do the completion of shared tasks such as the building and maintaining of wells (Hovden 2014, 61). Nonetheless, inter-tribal relations and the conflicts arising from them are of major concern in Yemen's tribal society, since these conflicts, due to the internal logic of the tribal organization of society, can easily spin out of control (Dresch 1993, 84-85 and Jamous 1992, 172-173).

Tribes are already attested in pre-Islamic inscriptions (Robin 1982) and Islamic historiographers report that tribes such as Banū 'Aws and Banū Khazraj come from South Arabia end settled in Medina in pre-Islamic times (Watt 1953, 141). On tribal self-identification, see Najwa Adra's chapter in this volume.

$4 \quad$ In reality, tribal membership above the level of the extended family and below the level of tribal confederations tends to be defined in terms of co-territoriality (Adra 1982, 116-133; Weir 2007, 97). "What is important is not a verifiable chain of ancestors, in a positivistic sense, but social recognition and acknowledgement” (Meissner 1987, 177). 
[E]ach tribe divides and subdivides again and so forth until family units are reached ... From the viewpoint of any one individual or family, this means that he or it are at the centre of a number of concentric circles - the intra-village clan, the village, the group of villages forming a local clan, the larger clan, the tribe, and so forth (Gellner 1985, 117).

An individual is thus part of different nested segments at once; a conflict between two individuals can therefore quickly involve wider sections of society, not directly involved in the conflict. "This is embodied in the oft-cited Arabic saying 'I against my brother; my brother and I against my cousin; my cousins, my brother and I against the world"' (Combs Schilling 1985, 660).

This conceptualization of tribal societies is most commonly referred to as segmentary theory. As Dresch $(1986,309)$ says, this theory does not, however, deal "with sequences of events at the level of observation (and in particular with the appearance of groups) ... [but] deals with formal relations that characterize the types of events possible." Or, as Mundy $(1989,118)$ puts the same idea: "The tribal idiom was by its nature more an appeal to local men for common action than a description of obligatory association." Segmentary theory therefore does not sufficiently describe the actual workings of intertribal relations (Weir 2007, 2-3; Adra 1982, 114; Caton 1987; Peters 1990). The actual course events take is defined by sophisticated modes of tribal mediation, ${ }^{5}$ which help to contain the centrifugal forces inherent in the system. This is illustrated by a conversation Weir (2007, 192-193) mentions: Asked about how conflict would spread in a certain village, a shaykh answered: "If they have an internal dispute in al-Farq, everyone supports his own bayt. Then elders intervene and crush it by slaughtering, and force them to make it up and return to the right path (yiruddūhim). There must be no ganging up! It should only be one on one." While, in this example, the conflict in the village is contained by the elders, the function of mediator is often carried out by outsiders.

The conceptual equality of tribesmen and tribes, which Gellner alludes to in the quote above, is a function of their shared ancestry and predestines outsiders to mediate in tribal conflicts. It is therefore no wonder that many shaykhly families are said to have joined the tribe they represent relatively late, often only a few hundred years ago (Dresch 1984, 36-37). Another such group of outsiders are the aforementioned sädah (sg. sayyid) or ahl al-bayt, who for centuries have played an important role as mediators in Yemen's tribal society. As descendants of Muhammad, they are members of the North Arabian tribes, tracing their lineage back to their mythical ancestor 'Adnān. Traditional Arab genealogy states that he was a descendant of Ismā' 1 l, the son of Abraham, and therefore arrived only late to the Arabian Peninsula. Yemen's tribes, on the other hand, trace their roots back to Qahțān, who is said to have come to the peninsula shortly after the Great Flood. The Qahțānī tribes are therefore also known as al-'arab al-'arībah (roughly: original Arabs), while the 'Adnānī tribes are referred to as al-'arab almusta 'ribah (Arabized Arabs) (Orthmann 2002, 210-211).

The ancestors of most of Yemen's ahl al-bayt came in 897 together with Yahyā b. al- Husayn b. alQāsim al-Rassī, who later became known as Imam Hādī ilā al-Ḥaqq (Heiss and Hovden 2016a, 375 n. 26). Yahyā b. al-Husayn was invited to Yemen in order to settle a local dispute in the city of Șa 'dah. With him, he brought Zaydī Islam, and became Yemen's first imam. According to the most common forms of Zaydī Islam, every sayyid who fulfills certain criteria (such as being male, free, sane, pious,

For detailed descriptions of these modes of mediation, see Weir 2007, 143-225 and Dresch 1993, 75-197. 
just, brave and learned) and rebels against the unjust incumbent to the office of the imamate, can theoretically become imam. ${ }^{6}$

So while, according to Zaydī beliefs, society should be ruled by the sādah, in accordance with Zaydism's understanding of Islam, in reality the power of the imamic state was nowhere near absolute. The sādah, usually had a higher level of education than the rest of the population and traditionally filled high positions in the bureaucracy and the legal system. While they thus formed the upper stratum of Yemeni society, they did so in a society that remained tribal and to a large extent guided by principles and laws independent of Islam, in fact preceding it. So in other words: the sādah held their exalted societal position more due to their ability as outsiders to mediate in a society governed by secular principles, than due to the position Zaydi Islam ascribed to them. From imamic literature it becomes evident that the sādah were well aware of the problem and tacitly adapted to this contradiction between the "source of political leadership and the pretense of legitimacy" (Mundy 1995, 28).

This adaptation to the tribal environment is also seen in a passage from the biography of the first Yemeni imam, al-Hādī ilā al-Haqq, written by his cousin al-'Abbasī al- 'Alawī. In this account, the imam returns from his daily visit to the market and brings with him a coat embellished with silk. ${ }^{7}$ When he encounters the father of the author, he says:

"By God, if I was amongst believers I would not wear such a thing; this is not of my normal clothes. I would like to just dress in coarse clothes. But if I would not wear it [i.e. the coat] the people would judge my position lowly. I looked into their ways and saw that they only follow somebody who wears clothes like these. On my skin, however, it feels like it was made of thorns." (al-'Abbasī al-'Alawī 1972, 56).

The reason for the imam's apology to his uncle is that in many interpretations of Islam, obviously including the interpretation of the imam, the wearing of silk is forbidden for men. The imam is clearly aware that he has to make amends in terms of religious purity in order to satisfy the expectations of his subjects; on the other hand, he apparently also feels that this behavior distracts from the respect those that judge him by religious standards have for him.

Due to the fact that the sädah's legitimacy rested on their claim to religious leadership, however, the issue was normally not addressed openly, as Gellner $(1984,21)$ writes:

A person who made it plain that his confidence in his own supposedly unnegotiable basic position is less than total, and that he is keeping an alternative ready and available, would thereby undermine the credibility of his own stance... Thus the alternatives are decently hidden away.

This tendency is clearly seen in the imamate's dealing with tribal customary law ('urf). Due to its secular nature, tribal law, strictly speaking, fell outside the purview of the imamic state. Since openly engaging with it would constitute an acknowledgment of its validity, doing so would undermine the

$6 \quad$ For general information on Zaydism, see Strothmann 1912 and Madelung 1965. For a biographical account of Imam Yahyā's life, see Van Arendonk 1960.

7 The term used here (qabä' mulham) is explained by Mundy (1983, 531 n.12), who also cites the same passage: "A qabā' is an open-front coat, probably like a șāyah. Mulham is stuff with a warp of silk and a woof of some other material." 
imamate's claim to being the sole source of legitimate authority. Imamic literature therefore frequently reviled tribal customary law and practices publicly, often referring to it as țagh $\bar{u} t$ (roughly: idolatrous practice). In reality, however, the imam had to adapt to these practices. He therefore, for example, sent emissaries to negotiate in tribal affairs or tolerated some principles of 'urf that did not openly contradict the sharī'ah (Dresch 1989, Rathjens 1951, and Rossi 1948).

All of this does not mean that personal piety amongst the tribesmen was of no importance, nor that consequently the sādah's religious status did not benefit their societal standing and their authority in mediations, quite the opposite (Caton 1990, 94, 108, 116; Dresch and Haykel 1995, 418; Serjeant 1982, 12). The problem, however, remains the same: from their own point of view, the $s \bar{a} d a h$ were at the top for the wrong reasons.

What is more, both of the sources of their authority, be it in the secular or the religious sense, are based on them being outsiders to tribal society. Their ability to mediate in tribal conflicts is based on their standing outside the tribal order, while their standing as a religious elite was legitimated and based on Zaydī principles, privileging North Arabian tribal ancestry. As long as the state claimed for itself to be religiously legitimized, however, they were still part of that state. With the abolition of the imamate in 1962 and the reinvention of Yemen as the home of a particular Yemeni nation, things changed dramatically for the $s \bar{a} d a h$.

After 1962 the ancien régime was officially derided as tyrannical, racist and accused of dividing the country, ${ }^{8}$ and the newly established republican state tried to create a shared national identity based on a non-sectarian state Islam (vom Bruck 1998; King 2012) as well as Yemen's historic (Stookey 1978, 24) and tribal heritage (Adra 1993; Varisco 2017, 241). Thus neither Zaydism nor the sādah lost much of their societal standing in practical terms, but theoretically also stood outside the conceptual realm of the new nation-state. ${ }^{9}$ Under the imamate, the sädah's claims to authority on account of them being from the family of Muhammad and therefore of 'Adnānī descent were not only in line with the precepts this state purported; they were the essence of the imamic state itself. If a Zaydī state is defined by its application of Zaydī Islam and Zaydī Islam demands the leadership of the ahl al-bayt, ${ }^{10}$ such a state can only be upheld if the ahl al-bayt claim authority. Yet, with the connection of notions of a Yemeni nation with the country's tribal and pre-Islamic cultural heritage, claims to the leadership of the ahl al-bayt were inherently at odds with the republican state on a political level, while every highlighting of descent from outside Yemen at the same time re-enforced the sädah's position outside the envisioned national community. Their exclusion went to the heart of what it now meant to be Yemeni. By introducing South Arabian descent as a marker of "true Yemeniness," the sädah conceptually became foreigners. The idea of sādah supremacy, however, persisted and made a comeback in the early 2000 s.

A good example for this is the republication of al-Zubayrī's Al-imāmah wa-khataruhā 'alā wahdat al-Yaman in 2004 by the ministry of Culture and Tourism. Tellingly the book opens with a foreword by then-president 'Alī 'Abd Allāh Șāliḥ in which he states that this book should be read by every Yemeni as a warning of the dangers of the imamate to the unity and safety of Yemen.

$9 \quad$ On this point, see also Bonnefoy 2011, 226-228.

10 In traditional interpretations of Zaydism there is, should there for some reason be no imam, the possibility of a so-called muhtasib, a sort of steward of the vacant imamate who does not have to be from the ahl al-bayt, see Strothmann 1912 , 86-87. For the Mutarrifiyyah, a form of Zaydism not conforming to standard Zaydī conceptions of legitimate rule, see Heiss and Hovden 2016a. 
The Hūthīs and the Attempt to Make Zaydism Yemeni Again

As a result of the profound social transformations setting in in the 1970s with the influx of oil money, new irrigation technologies and aggressive forms of Sunni Islam from Saudi Arabia and Egypt, as well as the opening of new political possibilities, especially for tribal elites, the tribal system began to show cracks (Brandt 2017, 35-74). In this context of a weakening and coopted tribal system and the onslaught of an alien and state-sponsored form of Islam in combination with the more liberal political climate after the Yemeni unification in 1990, Zaydī scholarship slowly began to make a comeback (Dorlian 2013). First, Zaydī scholars such as Aḥmad al-Shāmī or Zayd al-Wazīr tried to reintegrate Zaydī doctrine into the republican system by abandoning the idea of an imam from amongst the ahl al-bayt (vom Bruck 1998); later, more intransigent voices like Zayd 'Alī Muṣlị̣ and Ḥusayn al-Ḥùthī appeared.

Husayn al-Hūthī was the scion of an old but historically not overly important sayyid family, which had made a name for itself through its charitable works and tribal mediation in northern Yemen (Brandt 2017, 139-144). Between 2000 and 2003, al-Hūthī gave around a hundred speeches in Yemen's Șa 'dah province. Collectively they became known as the Maläzim Husayn al-Hūthì. After Husayn's death in the first round of the Hūthī conflict in 2004, he became a martyr figure, as is evident in the honorific al-shahìd al-qä 'id (the martyr leader), which is now commonly bestowed upon him. At the same time, his speeches developed into the ideological foundation of the movement. ${ }^{11}$

Al-Hūthī is surprisingly clear on the role he envisions for the ahl al-bayt. Contrary to al-Shāmī and al-Wazīr he clearly envisions a leading role for the descendants of Muhammad.

We say: We are the Zaydiyyah, the Zaydiyyah is the correct faction (al-tâ' ifah al-muhiqqah), the Zaydiyyah is the best of factions (safwat al-tawa' if), we are the people of correct beliefs ... And those of us who are from among the ahl al-bayt, we say: We are from the ahl al-bayt, we are those of whom Allah took away the uncleanliness and purified them thoroughly (adhaba Allāh 'anhum al-rijs wa-țhharahum tathìran). We are those whose love has to be for the ummah, those who have to cling to it. We are those who have to cling to them to protect them from going astray. And so on and so on ... But is it of the logic of the Quran (mantiq al-Qur'än) that you can attribute those things to yourselves without accepting the responsibility that comes with them? There is a responsibility, a large responsibility! (Ḥusayn al-Ḥ̂̀thī, 2002c)

Also:

Don't expect those that are angry at the ahl al-bayt or don't believe in the culture of the ahl al-bayt to be victorious against the Jews ... The prophet - șalawāt Allāh 'alayhi wa-ālihi - said: "I am leaving among you [two weighty things, (thaqalayn)], ${ }^{12}$ if you cling to them, you will not go astray after I am gone: The book of Allāh and my descendants, the ahl albayt." (Husayn al-Ḥūthī 2002e)

\footnotetext{
11 His speeches continue to be referenced in abridged form in magazines (Ḥusayn al-Ḥuthī 2016, 4-6), poems are composed in his honor (al-Dakkāk 2017, 61) and his picture is frequently used in posters and graphic designs.

12 Al-Hūthī leaves out the word "thaqalayn" here, yet mentions it in the context of the quoted passage.
} 
In the first quote, al-Hūthī clearly refers to the Hadith of the Cloak, ${ }^{13}$ while in the second he refers to the Hadith of the Two Weighty Things. ${ }^{14}$ Besides Muhammad's sermon at Khumm, which culminates in the sentence: "He of whom I am the mawla (roughly: guardian), of him 'Ali is also the mawlā," which Husayn al-Ḥ̄thī also quotes (2002a), these passages are two of the main traditions commonly used to legitimize the ahl al-bayt's claim to political authority.

Husayn al-Hūthī calls upon the ahl al-bayt to become aware of what he sees as their responsibility towards the ummah and lead it in the fight against what he saw as Western imperialist intrusion into the Middle East in the wake of the so-called War on Terror. Only led by the ahl al-bayt could the ummah survive in the face of Western and Zionist imperialism; after all, he argues, it was only 'Alī who could breach the walls of the fortress of Khaybar, not Abū Bakr, nor 'Umar (Husayn al-Hūthī 2002c, 2002a, 2002d).

Guided by the ahl al-bayt, Yemenis should unite in a culture defined by Islam, which he calls the "Quranic Culture" (thaqāfah qur'āniyyah).

We, if we don't believe in the Quranic Culture will lose everything, we will return to an illiteracy worse than the first [i.e. before Islam]. God described this illiteracy as "they had been before in manifest error" (Al 'Imrān: 164) ... Because we fail to follow our religion, to hold on to its values, we lost also the values of our human nature (qiyamnā al-insāniyyah al-tabi' 'iyyah) that humans like every other living being (ka-ayy haywān äkhar) possess. Do humans not have feelings of anger (ghadab), sometimes he is angry? This is a matter of nature and instinct (shay' fitrī wa-gharīzì), love of revenge (intiqām), love of sacrifice (tadhiyyah) for something that is dear to him? We will be more illiterate than the illiterate Arabs were then [before Islam]. There is no religion amongst us, there is no mutual help (najdah), no honor (karāmah), no courage (shajā'ah), no proud refusal (ib $\left.\bar{a}^{\prime}\right)$, no chivalry (furūsiyyah), and nothing else (Ḥusayn al-Ḥūthī, 2002e).

These categories, mutual help, honor, courage, chivalry and proud refusal are clearly categories familiar to people brought up in Yemeni tribal society. These values are, however, mentioned in a universal, Arab context, which becomes clear as he continues to argue that before the advent of Islam, the Arabs holding on to these values were stronger than "the Jews" (Husayn al-Hūthī, 2002e). While alluding to these indigenous values and ideals, not necessarily connected to Islam, he hardly mentions the tribes ${ }^{15}$ or the tribal system. Unlike the imams, he does not denounce the mechanisms of the tribal system. Different

13 "The prophet went out one morning wearing a striped cloak of the black camel's hair. Then came Hasan b. 'Alī and he took him under it, then came Ḥusayn and he took him under it, then came Ḥasan and he entered with him. Then came Fāṭimah and he took her under it, and then came 'Alī and he took him under it. Then he said: "God only wants to remove from you all that might be loathsome, O you members of the [Prophet's] household, and to purify you to utmost purity. (Innama yurīd Allāh l-yudhhaba 'ankum al-rijs ahl al-bayt wa-yuțahhirakum tațhīran)" [Quran 33:33]" (Șahịh Muslim: 2424).

14 On his way back from the last pilgrimage to Mecca, Muhammad and his followers rested at a watering place called Khumm. Feeling his death coming, he said: "I am leaving amongst you two weighty things. If you hold on to them, you will not go astray after me. One is bigger than the other: the Book of Allāh, it is a rope that reaches from heaven to the earth. The other are my descendants, my ahl al-bayt. They will never be separated from each other until they return to me at the Pond [i.e. the Pond of Abundance (Hawḍ al-Kawthar) in paradise]." (Jāmi ‘ al-Tirmidhī: 3788)

15 For an exception, see Husayn al-Hūthī (2002b): here he uses the ideal of tribal unity to warn of the dangers of pluralism in religious matters. He uses an example with which people are familiar, yet he does not acknowledge the value of the tribal systems as such. 
from the $s \bar{a} d a h$ during the imamate, al-Hūthī's problem was not so much the existence of tribes or the tribal system per se but, as described above, the theoretical implications of the elevated importance of Qaḥtānī descent and, tightly connected to that, the focus on Yemen's pre-Islamic heritage. Husayn al-Hūthī seems to have been aware of these problems and addressed them. He strongly criticized the government's attempts to build a Yemeni nationalism on the basis of pre-Islamic history. "The Jews", as he said, worked through the Yemeni government to evoke an interest in the population in the history of the pre-Islamic Yemeni kingdoms of Saba', Himyar, and Ma'īn. Just as in other countries like Egypt, Iraq, and Syria, the population would be diverted from Islamic history and thus made complacent in the face of Jewish supremacy over them. Islam would be cast aside and be perceived as an idolatrous deviation from the freshly imposed quasi-religious devotion to pre-Islamic heritage.

They lay out their principles in one way or another. They make the honoring of the spiritual authorities (awliy $\vec{a}^{\prime}$ Allāh), the preservation of attention to certain characteristics of the authority (hifäz 'alā ma' älim mu'ayyanah 'alā wal̄̄), of the Imam, of the birthday of the prophet - șalawāt Allāh 'alayhi wa-ālihi -, of every Islamic influence ... the attention to that, the honoring of that, an expression of a heterodox innovation (bid 'ah) and idolatry (shirk) (Ḥusayn al-Ḥūthī 2001).

In reality, however, the Yemenis and 'Alī and consequently the ahl al-bayt, he argues, share a common bond. Only by reviving that bond could, as mentioned above, Yemen and the Islamic world return to strength. That bond, he argued, becomes apparent in the steadfast loyalty of the Yemeni people towards the ahl al-bayt.

In their history, the people of Yemen (ahl al-Yaman) always fought (yujāhidūn) under the banner of the ahl al-bayt. They left the indigenous rulers (sulțānat ukhrā qā'ima 'alā turāb hädha al-wațan) ... They did not say: "These are the sons of our homeland and those are intruders, they stood with the ahl al-bayt" (Husayn al-Ḥuthī 2002e).

These attempts to reintroduce the sādah as an integral aspect of Yemeni society became more pronounced after the movement spread in the aftermath of the Arab spring. After Husayn al- Hiūthī's, death in August 2004, the leadership of the movement passed briefly to his father, Badr al-Dīn al-Hūthī, and then to his younger half-brother, 'Abd al-Malik. Between 2004 and 2010, the movement fought six wars against the Yemeni government and participated in the revolution of 2011 (Brandt 2017; Salmoni, Loidolt, and Wells 2011). In March 2005, Badr al-Dīn al-Hūthī gave an interview in which he clearly states the imamate was preferable to democracy and that the imamate could only be held by male descendants of Hasan and Husayn. He, however, denies that Husayn aspired to the office of the imamate himself (alAmir 2005). In how far Badr al-Dīn al-Ḥūthī's views are representative for the movement at this point must remain open to speculation. Also, the ideology of the group during the period between Husayn al-Ḥuthī's death and the Arab Spring, for which only relatively few original sources remain available, has not been analyzed in detail yet. In general, however, the movement during this phase seems to have concentrated mainly on political issues. It appears that only after taking over control over Șan' $\bar{a}$ ' in 2014, and especially after 'Alī 'Abd Allāh Șāliḥ’s assassination in December 2017 did the movement seem to become more specific in its religious claims.

Marching down south from Șa dah province in 2014, the Hūthīs brought large parts of the country under their control, swimming on the one side on a wave of popular support due to their active stance 
against the corrupt and ineffective government ${ }^{16}$ of 'Abd Rabbihi Manșūr Hādī and brutally crushing tribal resistance (Lackner 2018, 160-162; International Crisis Group 2014, 11; Brandt 2018, 174-178). In control of wide parts of the country, for many Yemenis the movement became the only defense against the attacks of the Saudi-led-coalition, which plunged the country into chaos. With the country crumbling under the weight of the bombardment, the humanitarian crisis and internal displacement, for many Yemenis the Hūthīs seem to be the lesser evil compared to foreign occupation and complete societal breakdown. Profiting from an emerging war economy (Salisbury 2018, 7), the movement is currently without any real rival from within. Thus empowered, the $s \bar{a} d a h$ made a comeback to leading positions in many sectors of public life ${ }^{17}$ (Lackner 2018, 165), a new head mufti was installed (Yemen Press 2017), school books seem to have been changed in accordance with the movement's religious ideas (al-Yaman Today 2017) and books on social issues such as on the role of women in Islamic society ('Abd al-Malik al-Hūthī 2018) were published.

Also, with regards to the imamate, the movement is getting bolder. The following is from a recent publication by the movement via the Majlis al-Zaydī al-Islāmī (Zaydī Islamic Council) ${ }^{18}$ :

Lately, Yemen went through a phase of darkness, distortion and plagiarism not seen before in her history nor in her defining and cultural heritage (turāthuha al-rā'id wa-l-khad̄ârî). Imam Hādī ilā al-Ḥaqq was a great Imam and it is mandatory that we praise him, his ideas, heritage and cultural and intellectual influence, but unfortunately he and the majority of distinguished men of Islamic thinking in Yemen, were exposed to neglect and forgetting. And if research was conducted on them, they [the researchers] were treated in a derogatory, biased and distorted manner, resulting from self-serving interests of corrupt politics, the excretions of the odious takfiri madhhab and the epidemic from the Kingdom of the Horn of Satan (Mamlakat Qarn al-Shaytān $n^{19}$ ) [i.e. the Kingdom of Saudi Arabia] - the tip of the spear of the Zionist American project in the region - of which the ongoing aggression [i.e. the Saudi-led intervention in Yemen] is but one visible aspect. It is unthinkable and unnatural that the Yemeni people be prohibited from their Islamic, Arabic heritage and their centuries old historic identity, just because of the sudden urge to modernize, which is not an expression of the Yemeni identity, but of the opposite, that is the identity of the Najdi Satan that harmonizes with the American/Zionist project (Anonymous 2018, 6-7).

The book hails Imam al-Hādī ilā al-Ḥaqq as a fair and just ruler and brave fighter, courteous to his enemies. The fact that he was invited to settle a dispute and came only with very few men - the book

For, a speech by 'Abd al-Malik al-Ḥūthī addressing this issue, see 'Abd al-Malik al-Ḥūthī 2014.

For a list claiming to detail high official positions that went to $s \bar{a} d a h$ under the Hūthīs, see Yemen Press 2016.

The Majlis al-Zaydī al-Islāmī seems to be formally independent of the Hūthī movement, yet clearly serves as an ideological mouthpiece. It for example publishes favorable books on issues relevant to the movement, including speeches and books by 'Abd al-Malik al-Ḥūthī; it distributes a journal (al-Shamārah) lauding the movement; and it holds conferences on relevant issues such as the imamate. Many activities of the organization are covered by al-Masirah, the Hūthī movement's television station. This includes the conference out of which the publication cited here developed (al-Masirah 2017). Writers of the Majlis are also active for the Dā’irat al-Tarbawiyyah li-Anșār Allāh (Educational Department of Anșār Allāh), a Ḥuthī-affiliated think tank.

19 The appellation "Qarn al-Shaytān" was already used in the $13^{\text {th }}$ century in Zaydī writing in order to decry the people from the Najd (Rossi 1948, 11). The Saudi Arabian kingdom has its roots in the Najd. 
speaks of fifty - is interpreted as a sign of his benevolent intentions and serves as proof that he had no way to coerce the local population into following him. According to the book, he was generous to the poor, especially the orphans of the martyrs, and used the zakāh only for the benefit of the state. With the zakāh, he set up an "Economy of Resistance" (iqtișād al-muqāwamah), which relied on self-sufficiency. Here it becomes clear that the imam is seen as an example for the present age:

[His] reliance on the zakāh as primary source of income in order to administrate the young country may today appear miraculous and phantastic, but history tells us it is possible. But only by improving the collection and distribution. The method of Imam al-Hādī ... ensures us today to improve the societal sources of revenue and ... expand our administrative efforts. This is certainly a big undertaking, that will help us with God's help to get through this trial (mihnah), through which the enemy wants to vanquish us, but this will never happen. (al-Ahnūmī 2018, 32)

Together with such calls to take the past as an example, ${ }^{20}$ a trend to portray the movement as an indigenous actor becomes notable. While to a smaller degree this can, as mentioned above, already be observed in the speeches of Husayn al-Ḥuthī, now in power over large parts of Yemen, the movement seems to see an increasing need to present itself as a decidedly Yemeni actor. 'Abd al-Malik al-Ḥuthī now commonly begins his speeches with the phrase: "Oh brothers and sisters, our mighty Yemeni Muslim people (sha'bnā), peace be upon you and the mercy and blessing and Allah." ${ }^{21}$ What is particularly noteworthy with this phrase is the use of the word "sha ' $b$ ", which means "people" but has a national and/or racial connotation. Imam Yahyā (d. 1948), for example, commonly used the more innocuous term "ahl" instead (Wedeen 2008, 34-35). In power over large parts of Western and Upper Yemen, the movement is now also forced to engage with tribalism as a means of societal organization. In 2014, for example, al-Masirah proudly announced that 'Abd al-Malik al-Ḥūthī had settled a conflict between the tribes of al- 'Atīn and Banū Suwayd in Dhamār, allegedly ending a feud lasting for thirty years (Youtube 2014). In highlighting such efforts, the movement is faced by the problems outlined above, namely that by mediating in tribal disputes, they implicitly acknowledge the existence of secular forms of authority independent of their own religiously legitimized claims to leadership. So while reality is never as clearcut as theory and arguably every political actor has to make concessions in terms of doctrinal purity, the Hüthīs now seem to try to connect Yemen's tribes with religion in order to make Zaydism, and with it the ahl al-bayt, "truly Yemeni" again. In 2018 the Majlis al-Zaydī al-Islāmī published the book alYaman wa-ahl al-bayt fì șadr al-Isläm (Yemen und the Ahl al-Bayt in the Beginning of Islam) as the first installment of a series called Silsilat al-Yaman wa-ahl al-bayt (Series of Yemen and the Ahl al-Bayt):

20 In similar vein, for example, 'Abd al-Malik al-Hūthī likens Imam Zayd b. 'Alī’s resistance against the Umayyads to the Yemenis' fight against the Saudi-led coalition ('Abd al-Malik al-Ḥ̂thī 2018).

${ }^{21}$ "Ayyuhā al-ikhwah wa-l-akhawāt, sha'bnā al-Yaman̄̄ al-muslim al-'azīz, al-salām 'alaykum wa-rahmat Allāh wabarakātuhu." 
[The book's purpose is to] show in all clarity that Yemen has preserved its respectful and loving relationship with the Hashemite ${ }^{22}$ house from which Allah has chosen the noble prophet - șallä Allāh 'alayhi wa-älihi wa-salam - even before the advent of Islam. This relationship remained good and fine and as Islam arrived, it changed into a religion that encompassed all the hearts of the Yemenis and brought them near to Allāh - 'azz wajall ... This special relationship formed the gentle power (al-quwwah al-nä imah), which enabled the emergence of the imams of the ahl al-bayt and the founding of the just state of Islam (dawlat al-Islām al- 'âdilah) that lasted more than a thousand years, beginning with the state of Imam al-Hādī ilā al-Ḥaqq Yahyā b. Husayn ... Despite the attempts of the others to sever the historic emotional and contractual bond (irtibāt al-wajdān $\bar{\imath}$ wa-l- 'aqd al-tārikhīayn) between the two, Yemen has not even for one day abandoned the idea of the ahl al-bayt. This is what those trying to repeat these attempts should understand (alAhnūmī 2017, 66-67).

In 2018 al-Masirah, the movement's Beirut-based TV-station, broadcast a documentary movie called alMawaddah al-Khälidah (The Everlasting Affection) which outlines the envisioned connection between the ahl al-bayt and the tribes explicitly (al-Masirah 2018). The documentary starts with the story of the Banū Jurhum, a Qaḥtānī tribe from Yemen, which is said to have settled in Mecca in pre-Islamic times. There it established marital connections with Ismā' 1 l, a forefather of 'Adnān and thus also of the ahl al-bayt. Later the Banū 'Aws and Banū Khazraj settled in Medina and women of the Banū Khazraj, including Muhammad's grandmother and great-grandmother, married into the Quraysh. Muhammad thus had close familial ties to Yemen. Later members of the two tribes were amongst the first Muslims of Medina (al-anșār), helping Muhammad to escape from Mecca. The film goes on to tell the story of how Hamdān, one of the two big tribal confederations in Yemen, converted to Islam in "a single day" and how it continued to play a major role by supporting 'Alī in the war against Mu'āwiyah $b$. Abī Sufyān. Even today, the film alleges, this "everlasting affection" has not changed.

By selectively drawing on well-known passages of Islamic historiography, the Hūthīs are able to give examples underpinning the presumption of the existence of an almost primordial bond between the Qaḥtạnī and 'Adnānī tribes and thus between the ahl al-bayt and the Yemenis of Qaḥțānī descent. These arguments are often given additional gravity through the use of poetry, which serves as a sort of direct quote of the actors involved in the mentioned historic events. ${ }^{23}$ A case in point is the recitation of an oft-cited poem in which 'Alī is said to have honored Hamdān at the battle of Șiffīn:

As I saw horses impaled by spears

- their riders' throats reddened with blood

I turned to those of Hamdān

- should it ever come to it, they are my shield and my arrows

they do not ride into battle unarmed

22 The term "Hashemite" is, like here, often used synonymously with sayyid in order to denote a member of the ahl albayt. Strictly speaking this is not necessarily correct. While the ahl al-bayt or sādah are, as previously mentioned, descendants of Muhammad through his daughter and son-in-law, "Hashemite" refers to descendants of Muhammad's great-grandfather Hāshim b. 'Abd Manāf. Every sayyid is thus a Hashemite, but not every Hashemite is a sayyid.

23. On the (un-)reliability of early Islamic sources, see Donner 2011. 
- tomorrow is war and from Shākir ${ }^{24}$ and Shibām

and of Arhab are the noblest of my comrades in arms

- Ruhm and the factions of Sabī ${ }^{`}$ and Yām

and of al-Wādi 'ah are exceedingly brave, feared are their traps

- attacking with sharpened swords in their hands

Hamdān is elevated by their character and belief

- as well as by their strength and, if need be, vigor in battle

they are elevated by their solemn and honest speech, their support

- and their knowledge should they utter noble words

if I was the guard at the gates of paradise

- I would say to Hamdān: Enter in peace!

(al-Masirah 2018, min. 52:09-53:42)

What becomes evident in the depiction of the tribes in the book and the documentary movie is that they are primarily portrayed solely as kinship entities. Customary law and tribal methods of conflict mediation are only given a role in so far as they support the immediate political interest of the movement. Like under the imamate (Dresch 1993, 186), tribalism is generally not conceptualized or even alluded to. Tribes are mentioned, yet not portrayed as parts of a society, which is, to a certain extent, still organized around tribal forms of rule. Reduced to the kinship aspects of tribalism, a tribe becomes simply a group of people drawn together by varying degrees of inter-relatedness, and is in that regard not different from the ahl al-bayt themselves. Such groups can then be inscribed with new meaning in accordance with the movement's goals.

\section{Conclusion}

Looking at the movement's two most productive periods in terms of its ideological output, this chapter aimed to shed light on the Hiuthī movement's strategies to legitimize its claim to religious rule. In both of these periods, the phase of the inception of the movement under Husayn al-Hîthī in the early 2000s and the phase of active political leadership after 2014, the movement claims the right for the ahl albayt to rule. This call is more pronounced in the case of the speeches of Husayn al-Hūthī. In these he makes frequent reference to the necessity he sees for reestablishing the active political leadership of the descendants of Muhammad. How this should be achieved and what this role should actively look like, however, he leaves largely unaddressed. The contemporary movement, on the other hand, is, as of the time of writing, already in control of wide parts of Yemen. In this context, the movement's narratives concerning the imamate seem to be primarily oriented towards legitimizing this kind of religio-political authority with recourse to the early imamic times.

At the same time, the Hūthī movement expends a considerable amount of effort to portray itself as a quasi-indigenous movement, deeply rooted in Yemen. In so far as what is considered to be indigenous is determined by Qaḥtānī heritage, such claims are, however, contradicted by the Zaydī legitimization of religio-political rule employed by the Hüthīs, which demands that leadership should lie in the hands of a member of the ahl al-bayt. As became evident from the discussion of the status of the ahl al-bayt under

24 Shākir, Shibām, Arḥab, Sabī’’, Yām, Ruhm and al-Wādi 'ah are segments of Hamdān. 
the imamate and under the republican system, the Hiuthīs, in the absence of a decidedly religious state, now face considerable obstacles to argue convincingly for the "Yemeni nature" of their movement. While, as mentioned in the beginning, societal realities are never even nearly as clean and tidy as they may appear conceptually, and the amount of legitimacy the Hūthīs enjoy is, of course, not solely dependent on their ethno-religious credentials, the perception of the ahl al-bayt as foreigners leaves them open for criticism and attacks. ${ }^{25}$ Husayn al-Ḥuthī acknowledged the issue but did not give it much room. The issue has only gained relevance and urgency with the Hüthīs' rise to power. Consequently, Yemen's tribes now play a relatively significant role in the movement's ideological output. They do so, however, mainly only as tribes, not as elements of a tribally organized society. With this reduction of the tribes to kinship groups, the movement is able to incorporate them into Zaydi conceptions of the ideal Islamic society, while at the same time portraying the Qahțānite population as closely tied to the ahl al-bayt.

\section{References}

al- 'Abbāsī al-'Alawī, 'Alī b. Muhammad b. 'Ubayd Allāh. 1972. Sìrat al-Hādī ilā al-Haqq Yahyā b. al-Husayn 'alayhi al-salām. Beirut.

Adra, Najwa. 1982. Qabyala: The Tribal Concept in the Central Highlands of the Yemen. PhD dissertation, Temple University.

1993. "Tribal dancing and Yemeni nationalism: Steps to Unity." Revue du Monde Musulman et de la Méditerranée 67:161-170.

— 2016. "Tribalism." In Encyclopedia of Islam and the Muslim World, $2^{\text {nd }}$ edition, edited by Richard C. Martin. New York: Macmillan Reference USA: Gale: 1185-1188.

al-Ahmmadī, Thābit, 2018. Al-Hādawiyyah: Bayna al-nathariyyah al-siyāsiyyah wa-l- 'aqūdah al-ilāhiyyah. Yemeni Ministry of Cultural Affairs.

al-Ahnūmī, Hamūd 'Abd Allāh. 2017. Al-Yaman wa-ahl al-bayt fì șadr al-Islām. Șan 'ā': Majlis al-Zaydī al-Islāmī.

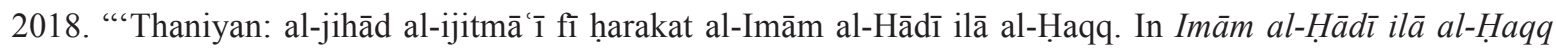
Yahyā b. al-Husayn: Qi 'ädat al-jihād al-fā ilah wa-riyādat al-dawlah al-'ädilah: Majmū'at awrāq 'āmal quddimat fì nadwat dhikrā wușūl al-Imām al-Hādī ilā al-Yaman 'ām 1438h. Șan'â': Majlis al-Zaydī al-Islāmī: $20-41$.

'Āmir, Jamāl. 2005. "Badr al-Dīn al-Ḥūthī li-“l-Wasaț": Al-ra'̄̄s khāfa an ya'khudha Ḥusayn minhu al-wilāyah wa-lImāmah khāșșah bi-āl al-bayt”. Al-Wasat, 19 March 2005. http://alwasat-ye.net/index.php?ac=3\&no=32290.

Anonymous. 2018. "Muqaddimah." In Imām al-Hādī ilā al-Haqq Yahyā b. al-Husayn: Qi ādat al-jihād al-fā 'ilah wa-riyādat al-dawlah al- 'ādilah: Majmū' at awrāq 'āmal quddimat fì nadwat dhikrā wușūl al-Imām al-Hādī ilā al-Yaman 'àm 1438h. Șan'ầ': Majlis al-Zaydī al-Islāmī: 5-8.

Bonnefoy, Laurent. 2011. Salafism in Yemen: Transnationalism and Religious Identity. London: Hurst and Company.

Brandt, Marieke. 2017. Tribes and Politics in Yemen: A History of the Houthi Conflict. London/New York: Hurst/ Oxford University Press.

2018. "The Huthi Enigma: Ansar Allah and the 'Second Republic." In Yemen and the Search for Stability: Power, Politics and Society after the Arab Spring, edited by Marie-Christine Heinze. London: Tauris.

25 For an example published by the Hādī government, see al-Aḥmadī 2018. 
Caton, Steven C. 1987. "Power, Persuasion, and Language: A Critique of the Segmentary Model in the Middle East." International Journal of Middle East Studies 19 (1): 77-101.

1990. “Peaks of Yemen I Summon”: Poetry as Cultural Practice in a North Yemeni Tribe. Berkeley: University of California Press.

Combs-Schilling, Elaine. 1985. "Family and Friend in a Moroccan Boom Town: The Segmentary Debate Reconsidered." American Ethnologist 12 (4): 659-675.

al-Dakkāk, Șalāh. 2017. "Bayna yaday al-Ḥusayn” 'Alamuna, 3:61.

Dorlian, Sami. 2013. La mouvance zaydite dans le Yémen contemporain: Une modernisation avortée. Paris: L'Harmattan.

Dresch, Paul. 1984. "The Position of Shaykhs Among the Northern Tribes in Yemen.” Man, New Series, 19 (1): 31-49.

1989. "Keeping the Imam's peace: A Response to Tribal Order in the Late 1950s.“ Peuples Méditerranéens, 46:77-95

1993. Tribes, Government and History in Yemen. Oxford: Clarendon Press.

Dresch, Paul and Bernard Haykel. 1995. "Stereotypes and Political Styles: Islamists and Tribesfolk in Yemen." International Journal of Middle East Studies 27 (4): 405-431.

Donner, Fred. 2011. "Modern Approaches to Early Islamic Historiography." In The New Cambridge History of Islam, edited by Michael Cook et al., part 4, 623-647. Cambridge: Cambridge University Press.

Gellner, Ernest. 1984. "Doctors and Saints." In Islam in Tribal Societies: From the Atlas to the Indus, edited by Akbar S. Ahmed and David M. Hart. London, et al., 21-35. Routledge and Kegan Paul.

- 1985. Muslim Society. Cambridge, et al.: Cambridge University Press.

Gingrich, Andre. 1989. "The Guest Meal among the Munebbih: Some Considerations on Tradition and Change in 'aish wa milh in Northwestern Yemen." Peuples Méditerranéens, 46:129-149.

- 2015. “Tribe.”, In International Encyclopedia of the Social \& Behavioral Sciences, $2^{\text {nd }}$ edition, Vol. 4, edited by James D. Wright, 645-647. Oxford: Elsevier.

Heiss, Johann and Eirik Hovden. 2016a. "Competing Visions of Community in Medieval Zaydī Yemen." Journal of Economic and Social History of the Orient, 59:366-407.

_ 2016b. "The Political Usage of Religious and Non-religious Terms for Community in Medieval South Arabia: A Comparative Response to Gerda Heydemann's Chapter." In Meanings of Community across Medieval Eurasia, edited by Eirik Hovden, Christina Lutter and Walter Pohl, 61-77. Leiden: Brill.

Hovden, Eirik. 2014. "Birka and Baraka - Cistern and Blessing: Notes on Custom and Islamic Law Regarding Public Cisterns in Northern Yemen." In Southwest Arabia across History: Essays to the Memory of Walter Dostal, edited by Andre Gingrich and Siegfried Haas, 55-66. Vienna: Verlag der Österreichischen Akademie der Wissenschaften.

al-Ḥūthī, 'Abd al-Malik. 2014. "Nașṣ khutbat 'Abd al-Malik al-Ḥūthī fī dhikrā Yawm al-Walāyah ('İd al-Ghadīr) 2014-10-13.” https://www.alwatanvoice.com/arabic/news/2014/10/13/602921.html.

_ 2017. "Nașṣ khutbat 'Abd al-Malik al-Ḥūthī fī dhikrā istishhād al-Imām Zayd b. 'Alī 'alayhi al-salām 1439h. " https://www.sahafah24.com/show1147431.html.

2018. Tawșiyat al-Sayyid 'Abd al-Malik Badr al-Dīn al-Hūthī li-l-jānib al-nisā' bi-l-tārīkh 19 Rabī'al-Awwal 1434h. Șan 'ầ': Majlis al-Zaydī al-Islāmī.

al-Ḥūthī, Husayn. 2001. Yawm al-Quds al- 'àlamī

_ 2002a. Hadīth al-Walāyah.

2002b. Al-Islām wa-thaqāfat al-ittibā" .

2002c. Khatūrat al-marhalah.

2002d. Lan tarda' 'anka al-Yahūd wa-lā al-Nașārā.

2002e. Mas 'üliyyat ahl al-bayt. 
_ 2002f. Sürat al-Mā'idah, part 2.

2002g. Al-Thaqāfah al-Qur'āniyyah.

2016. "Walāyat Allāh subḥānahu wa-ta ālā hiyya walāyat raḥmah, ri āyah, tarbiyah, laysa mujarrad sulțah." Shamārah 7:4-6.

International Crisis Group. 2014. "The Huthis: From Saada to Sanaa.” Middle East Report 154.

Jamous, Raymond. 1992. "From the Death of Men to the Peace of God: Violence and Peace-Making in the Rif." In Honor and Grace in Anthropology, edited by John G. Peristiany and Julian Pitt-Rivers, 267-192. Cambridge: Cambridge University Press.

King, James R. 2012. "Zaydī Revival in a Hostile Republic: Competing Identities, Loyalties and Visions of State in Republican Yemen." Arabica 59:404-445.

Lackner, Helen. 2018. Yemen in Crisis: Autocracy, Neo-Liberalism and the Disintegration of a State. London: Saqi.

al-Masirah. 2017. "Iḥyā' dhikrā wușūl al-Imām al-Ḥādī ilā al-Yaman bi-1-Jāmi' al-Kabīr bi-Ṣan 'ā' .” https://www. almasirah.net/details.php?es_id=14707\&cat_id=3.

_ 2018. al-Mawaddah al-Khālidah. https://almasirah.net/gallery/preview.php?file_id=19653.

Meissner, Jeffrey. 1987. Tribes at the Core: Legitimacy, Structure and Power in Zaydi Yemen. PhD dissertation, Columbia University.

Mundy Martha. 1983. "Șan' $\bar{a}$ ’ Dress, 1920-1975." In Șan ' $\bar{a}$ ': An Arabian Islamic City, edited by and Ronald Lewcock. London: The World of Islam Festival Trust: 529-541.

— 1989. "Irrigation and Society in a Yemeni Valley: On the Life and Death of a Bountiful Source." Peuples Méditerranéens 46:97-128.

1995. Domestic Government: Kinship, Community and Polity in North Yemen. London: Tauris

Orthmann, Eva. 2002. Stamm und Macht: Die Arabischen Stämme im 2. und 3. Jahrhundert der Hijra. Wiesbaden: Reichert.

Peters, Emrys L. 1990. The Bedouin of Cyrenaica: Studies in Personal and Corporate Power. Cambridge: Cambridge University Press.

Rathjens, Carl. 1951. “Tâghût gegen Scherî’a: Gewohnheitsrecht und islamisches Recht bei den Gabilen des jemenitischen Hochlandes.“ Jahrbuch des Linden-Museums, New Series, 1:172-187.

Robin, Christian. 1982. Les Hautes-Terre du Nord-Yemen avant l'Islam. Volume 1. Istanbul: Nederlands HistorischArchaeologisch Instituut.

Rossi, Ettore. 1948. "Il Diritto Consuetudinario delle Tribù Arabe del Yemen.” Rivista degli Studi Orientali, 23:1-36.

Salisbury, Peter. 2018. "Yemen's Cratered Economy, Glimmers of Hope?" The Arab Gulf States Institute in Washington.

Salmoni, Barak A., Bryce Loidolt, Madeleine Wells. 2010. Regime and Periphery in Northern Yemen: The Huthi Phenomenon. Santa Monica: Rand Corporation.

Serjeant, Robert B. 1982. "The Interplay between Tribal Affinities and Religious (Zaydi) Authority in the Yemen." al-Abhath 30:11-40.

Strothmann, Rudolf. 1912. Das Staatsrecht der Zaiditen. Strassburg: Trübner.

Van Arendonk, Cornelis. 1960. Les débuts de l'imāmat Zaydite au Yemen. Leiden: Brill.

Varisco, Daniel Martin. 2017. "Yemen’s Tribal Idiom: An Ethno-Historical Survey of genealogical Models.” Journal of Semitic Studies 62 (1): 217-241.

Vom Bruck, Gabriele. 1998. "Disputing Descent-Based Authority in the Idiom of Religion: The Case of the Republic of Yemen." Die Welt des Islams, New Series, 38 (2): 149-191.

Watt, Montgomery. 1953. Muhammad at Mecca. Oxford: Oxford University Press.

Wedeen, Lisa. 2008. Peripheral Visions: Publics, Power, and Performance in Yemen. Chicago: University of Chicago Press. 
Weir, Shelagh. 2007. A Tribal Order: Politics and Law in the Mountains of Yemen. Austin: University of Texas Press.

al-Yaman Today. 2017. "Mīlīshiyyah al-Ḥūthī tanshur kutub dirāsiyyah țā'ifiyyah fī madāris alMạ̣wīt." https://www.alyementoday.com/208/131001-\%D9\%85\%D9\%8A\%D9\%84\%D9

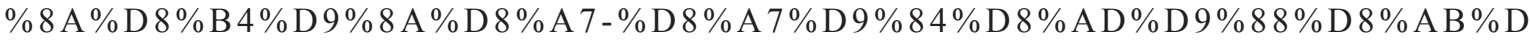
9\%8 A-\%D 8\%AA \%D 9\% 86\%D 8\%B 4\%D 8\%B 1-\%D9\%83\%D 8\%AA\%D 8\%A 8-\%D 8\%AF\%D8\%B1\%D8\%A7\%D8\%B3\%D9\%8A\%D8\%A9-\%D8\%B7\%D8\%A7\%D8\%A6\%D9\%81\%D9\%8A\%D8 \%A9-\%D9\%81\%D9\%8A-\%D9\%85\%D8\%AF\%D8\%A7\%D8\%B1\%D8\%B3-\%D8\%A7\%D9\%84\%D9\%85 $\% \mathrm{D} 8 \% \mathrm{AD} \% \mathrm{D} 9 \% 88 \% \mathrm{D} 9 \% 8 \mathrm{~A} \% \mathrm{D} 8 \% \mathrm{AA}$.

Yemen Press. 2016. "Qā'imah bi-ahamm manāṣib al-dawlah al-'uliyā allatî istafradat bi-hā ba'ḍ al-usar alḤūthiyyah.” https://yemen-press.com/news65895.html.

Yemen Press. 2017. "Man huwa al- 'alāmah al-jadīd alladhī 'ayyanahu al-Ḥūthiyyun muftīan li-l-diyār al-Yamaniyya khalafan li-1-Shaykh al- 'Amrānī." https://yemen-press.com/news94720.html.

Youtube. 2014. "Sayyid 'Abd al-Malik al-Ḥūthī yuṣlị̣ bayna qab̄ilah 'Atīn wa-Banū Suwayd bi-muḥāfaẓa Dhamār ba 'd iqtitāl dāma akthar min 30 sanah.” https://www.youtube.com/watch?v=6G5_HGe3lpo.

al-Zubayrī, Muḥammad Mạ̣mūd. 2004. Al-Imāmah wa-khataruha 'alā wah̆dat al-Yaman. Șan'ā': Ministry of Culture and Tourism of the Republic of Yemen. 


\title{
SOCIAL RESTRATIFICATION IN ḦADRAMAWT DURING THE LAST 25 YEARS: AN ANTHROPOLOGICAL OUTLOOK
}

\author{
MiKHAIL RODIONOV
}

Being a local version of the extensive phenomenon, the Hadramawt social stratification may be defined as a hierarchy of fixed social strata based on inherited status loyalty. Its essential core is the stratum of fully-fledged tribesmen with spiritual arbitrators above and the underprivileged non-tribal groups below. Strata hierarchy relies on 1) the principle of marital conformity with a tendency towards hypergamy, 2) a system of declared genealogies, and 3) the specific distribution of social and economic functions. Today the most active members of the low-status strata in Haḍramawt either seek their origin within the tribal context (of great value are freshly forged genealogical ties with the noble tribes) or prefer to join the Islamist radical groupings with acquired status.

My first visit to Vienna thirty-two years ago with a preliminary report on the field research in Hadramawt as a sociocultural anthropologist had been arranged by the Austrian anthropologist Walter Dostal. His perfect hospitality and encouraging help facilitated my entry into the everyday life of Haḍramawt in particular, and the interdisciplinary fields of South Arabian studies in general. To his memory as my ethnographic field-father I dedicate this chapter.

For many tribesmen and women of North Yemen in 1994, it was an overwhelming discovery that tribal organization and tribal honor, qabwalah (pronounced in the North as qabyalah), also existed in the South. Even in 2006, some Northerners took as breaking news my PowerPoint presentation about the influential Saybānī tribal federation (ziyy) of western Haḍramawt, their rites and customs including social presentations with tribal dances, songs and poetical improvisation. ${ }^{1}$

Tribes constitute an important echelon in the social hierarchy of South Arabia, the core stratum of the local system of fixed social strata with spiritual arbitrators above (sādah, the Prophet's offspring, and mashayikh, ${ }^{2}$ hereditary Islamic scholars) and the underprivileged below (hadar townsfolk, socially destitute masākin, socially weak $d u^{\prime}$ 'afă', socially underage șubyān, slaves, etc.). The stability of this flexible hierarchy is based on the inherited status loyalty and on the following principles: First, marital conformity with a tendency towards hypergamy (the brides are given within the same strata or above, whereas the grooms marry social equals or below); second, the system of declared/manipulated genealogies; and third, the specific distribution of social and economic functions (Rodionov 2006, 181-90).

In Haḍramawt, this phenomenon was studied by Robert Serjeant (1957), 'Abdallāh Bujra (1967 and 1971), 'Abd al-Qādir al-Șabbān (1984), Walter Dostal (1984 and 1985), Silvain Camelin (1997), Ulrike Freitag (2003), Engseng Ho (2006), etc. My ethnographic field research took place in 1983-

Rodionov 1996, 118-32; 1997a, 107-13; 1997b, 15-21; 2001, 263-75; 2009, 5-92; 2014, 49-88.

In the Hadramī context, shaykh (pl. mashāyikh) is a religious, not a tribal honorary title. 
2008 (Rodionov 2007; Rodionov and Schönig 2011). In the present-day Yemen, the process of social restratification has been gaining momentum since the unification of the country in 1990, the 1994 civil war, and the current conflict tearing Yemen apart.

The plateau-and-valley complex of Hadramawt (Rodionov 1993, 173-84) occupies the southeastern part of Yemen between Shabwah Province in the west and al-Mahrah Province in the east; it borders on Saudi Arabia in the north and the Arabian Sea in the south. Inhabitants of Hadramawt, the Hadramīs, traditionally regard their country as a landscape of death and burial and a gateway to eternal life. Denied by modern linguists, folk etymology still explains the name of Hadramawt as "presence of death." Moreover, in vernacular poetry the region is regularly rhymed with the Imperfect forms of the verb "to die." This semantic play reflects a local discourse which implicitly presents the region as a sacred landscape of death and burial (Rodionov 2010a, 342-45; 2014, 8-20, 89-129).

The most picturesque local features are shrines with their whitewashed domes or flat roofs. The main route in this symbolic space can be defined in one long sentence: a pilgrimage (ziyārah) to a sacred enclave (hawtah) to the shrine (qubbah) with the tomb (qabr) of a holy man (walī) being the patron (mawlā) of the area due to his, or sometimes her, vital force (barakah). Tombs of Islamic holy men stand by the cenotaphs of pre-Islamic prophets and ruins left by ancient tribes wiped out by God (Rodionov 2001, 263-76).

In the hub of the Wādi Hadramawt (see the map accompanying this chapter), one can find the tomb of the first sayyid who immigrated to the region in the $10^{\text {th }}$ century CE, Aḥmad b. 'Isā al-Muhājir, the forefather of the great $\mathrm{B} \overline{\mathrm{a}}$ 'Alawī clan, which consists of numerous families living all over the world (Freitag 2003; Ho 2006; Brehony 2017; Lackner 2017a).

Another sacred enclave, Mashhad 'Alī b. Hasan al-'Aț̣ās, $18^{\text {th }}$ century CE, is situated in Wādī Daw'ān, a southwestern tributary of the main Wādì Haḍramawt (Rodionov 2004, 307-12; 2017, 95108). During the pilgrimage to the sayyid 'Alī al- 'Atțās, water collected in reservoirs is blessed by the elder (manșab) of the local al- 'Ațāas clan. The act of giving water either by rain and flood or by subsoil sources is called al-rahmah, the [God's] mercy, so al-Rahmmān is regarded first of all as He who endows people with potable water (Rodionov 1999, 119-21).

Practically all venerated tombs in Haḍramawt are related to water and some affiliated folklore motives that retain chthonic features. Thus, the tomb of the pre-Islamic prophet Hūd bordered by the constant flood of Wādī Masīlah stands not far away from the legendary well Barhūt, believed to be a path to the afterlife at the utmost eastern extremity of the wādī. This ritual complex, the most significant in the area, is served by the mashāyikh hereditary groups.

Kawr Saybān plateau, the abode of Saybān tribes to the southwest of Wādī Haḍramawt, is famous for its sacred memorial of Mawlā Mațar, or the Patron of Rain. It retains pre-Islamic features and an explicit tribal air, free of the sädah and/or mashäyikh influence. The sketch and plan of the Mawlā Mațar memorial was drawn in 1993 by the Russian architect Yuri Kozhin during our three-day visit to Kawr Saybān (Rodionov 2014, 114-129, Illus. 1-20).

The traditional arbitrary and religious functions of the $s \bar{a} d a h$ as the Prophet's descendants have been harshly contended at least from the $19^{\text {th }}$ century onward. The well-known Irshādī- Alawī conflict between the Hadramī reformers can be seen in part as a struggle against the marital conformity rules which destined the sādah women to be married within their stratum only. Following the Saudi Arabian Wahhabi standards, the Irshādīs of Haḍramawt and diasporas used to condemn regular visitations of the tombs of the pious awliyā', labeling the sādah and mashäyikh involved in this practice as quburiyin, or tomb worshippers (Rodionov 2007, 61-75; Rodionov and Schönig 2011, 13-21). 
Archaic rituals of the ibex hunt aim at demonstrating the viability of social stratification through which representatives of each stratum know their social place and functions. Nowadays, traditions of the ritual ibex hunt in Wādī Haḍramawt, in spite of all opposition from the Islamic radicals, are still alive, in particular in such centers as Dammūn, Tāribah, al-Qa 'ūẹah, Madūdah (the ritual is headed by the muqaddam al-qanīṣ, "leader of the hunt", Mubārak Bakhḍar), and al-Ghurfah (with the most impressive sham play performance after successful hunting). The scenery, however, has changed slightly since the late 1980s because oil industry activity has driven the ibexes away from parts of their habitat on the southern belt of plateaux to the northern plateau (Rodionov 1994, 124-28; Rodionov and Schönig 2011, 43-47).

Madūdah, an important agricultural settlement, renowned for its basketry and date palms, represents a successful attempt to alter the strata system in a traditional way. The local oral tradition repeatedly narrates stories about weaklings who dared to become tribesmen, about plowmen who pretended to proclaim themselves shaykhs, etc. Madūdah's folk poet, Rabī'ah 'Awadh Bin 'Ubaydallāh, told me a story of his native self-proclaimed tribe Bin "Ubaydallāh, "wrongly called Bin 'Ubaydillāh," whose eponym "was a ploughman." At the time of our conversations (autumn 2003), Rabī'ah Bin 'Ubaydallāh headed the tribal committee. In his house, which served as the meeting place of the committee, he kept the tribal archives, a brand-new genealogical tree in a golden frame, and various documents related to the history of the tribe. His community was officially registered as a fully-fledged tribe only after the unification of Yemen in 1991, when the authorities in San ' $\bar{a}$ ' started to promote the tribalization and Islamization of the South, quite contrary to the politics of the ex-PDRY (Rodionov 2005, 215-21; Rodionov and Schönig 2011, 46-7).

The Marxist regime in South Yemen, with its notion of social classes, tried not to alter but to undermine the strata system entirely through abolishing most of its social and economic functions and even the names of the strata. Instead, in their attempt to create regular social classes, they have replaced the labels 'abīd (slaves) and $d u$ 'afă' (weaklings) by "workers." Consequently, a popular socialist slogan "Workers of the world, unite" was widely misunderstood by common Yemenis who wondered: "Why should the slaves of the world unite?" Tribes had been repeatedly disarmed, tribal chiefs (maqāddimah) and tribal judges (hakam/hukkām) expelled.

In spite of all efforts, however, the rules of marital conformity have managed to survive, and, therefore, the system of social strata, even deprived of some of its social and economic functions, has reproduced itself over and over again. Destratification turned out to be restratification due to the alteration of the social roles and structures of certain strata.

Recent events show us some traditional forms of social mobility in action; they demonstrate in particular how declared genealogies can be manipulated. Today the most active members of the underprivileged strata in Hadramawt seek their origin within the tribal context. Of great value are freshly forged genealogical ties with the noble tribes of Kindah, tracing their origins back to Qahțān, the legendary ancestor of the South Arabian tribes. Thus, the reputed Haḍramī carpenters of the Bā Țarfī clan maintain that they are descendants "of the kings of Kindah."

The ex-underprivileged non-tribal strata members have established the "Kindah Society" under the patronage of the Kindah tribes, including the al-Șay'ar, who always declare that they have no friends. For certain remuneration, the genealogies of the ex-weaklings, masākin (the poor), are "reinstated, strengthened and completed." There is a permanent demand for genealogical experts able to complete this task according to old manuscripts and handwritten documents. Another way of getting rid of hereditary low status is to join a radical Islamists' organization or political movement. In that way 
we can explain the relative success of the AQAP (al-Qaeda in the Arabian Peninsula), jihadists and other extremists.

When, in 2016, the AQAP forces entered al-Mukallā, they blew up some minor qubbas of the sādah and requested from the city museum, housed in the Sultan's Palace of the al-Qu'ayți dynasty, a list of all pre-Islamic artifacts as fruits of pagan jāhiliyyah. Fortunately, the museum staff, headed by 'Abd al- 'Azīz Bin 'Aqīl, a member of the Russian-Yemeni Scientific Expedition (the RYSE), hid those items until the AQAP's retreat. The same menace for the cultural memory of Hadramawt may endanger the Museum of Archaeology, History and Anthropology in Say'ūn, previously the al-Kathīrī Sultan's Palace, headed by 'Abd al-Rahmān al-Saqqāf, also a collaborator of the RYSE. The potential target of the extremists in Tarīm is "unorthodox manuscripts" from Maktabat al-Ahqāf, the Manuscript Library, directed by Husayn al-Hādī, who obtained his high school diploma in the former USSR (Rodionov 2018a and 2018b). Small wonder that two museums of St. Petersburg, the State Hermitage and the Peter-the-Great Museum of Anthropology and Ethnography (Kunstkamera) as well as the Museum of Oriental Cultures in Moscow ardently supported the international campaign launched by UNESCO for the safeguarding of Yemen's cultural heritage. Up to now, however, Hadramawt, if compared with some other districts of South Arabia, has seen little fighting and most of the key decisions are reached there through negotiations.

The current social and political struggle in South Arabia can be interpreted as the interplay of cultural and political symbols and slogans seen on street walls and on the internet, mostly on Facebook. My recent data is derived from an online exchange with my Haḍramī friends in the field, as practiced by Marieke Brandt and other colleagues, who dub it a "digital anthropological approach" (Brandt 2017, 4-6 ). Thus, Fayșal Khamīs Bā Tays proudly posts online a photo of a defensive tower (dār or husṣn) from the plateau of his tribe, Sawt Bā Tays. Along with honeycomb and a jambiyyah curved dagger, it forms the symbolic triad of Hadrramī cultural identification (tower - dagger - honey), to which one can add the fourth element, the curved horns of the ibex, the most important emblem of the local ritual hunting.

A recent trend in present-day Haḍramawt is numerous historical accounts attributed to a certain tribe written by a native author from the inside. Some of these publications do not go much further than traditional genealogical revisions, which tend to heighten the social status of a group. However, other works aim to carry out a more ambitious task. Those authors lay emphasis not only on the noble origin of their tribe but also stress its extreme importance in social, economic, political, and cultural areas. To prove this point, they bring into play ancient chronicles, classical and folk poetry, handwritten documents, various samples of the oral tradition, and ethnographic data. It is worth mentioning that the apologist of the al-Jawhiyyin, which is an important part of the Saybān tribal federation, ascribes all Saybānī merits to his tribal group. These local publications can also be regarded as the fruit of social restratification (Rodionov 2011). In these publications, tribe is treated like an eternal social division created by God and certified by an oft-cited Quranic passage (49: 13): "O mankind, indeed We have created you from a male and a female and made you peoples (shu'üban) and tribes (wa-qaba' 'il) that you may know one another."

Social identification comprises at least three basic levels: 1) familial/tribal, 2) local (= a Hadrramī) and 3) regional (= a Southerner), to which we can add two comprehensive cultural traits: belonging to the world of Arabic speakers and to the community of Islam.

The problems of social and cultural identification have been repeatedly discussed both on tribal and all-Hadiramīs levels. On the internet, these attempts are sometimes illustrated with two posters. The first 
one announces the meeting held on 31 December 2015, by the Tribal Union of Hadramawt, the Branch of Seashore and Plateau, at the Bā-1- 'Ubayd tribal area, commemorating the $2^{\text {nd }}$ anniversary since the muqaddam of al-Ḥumūm tribe, Sa'd b. Hamad Bin Habraysh, was killed because of his active antiAQAP stance.

The second poster informs about the "Inclusive Hadhramout Conference" held on 22 April 2017 with 3001 participants from all over the province. According to this conference and other meetings, Haḍramawt seems to be a rather cohesive entity which seeks its political perspective either in autonomy within the Southern state, or even in complete independence.

The evolution of local political attitudes may be highlighted by a brief history of the al-Hirāk association. Established in 2007 by the Yemeni Social Party (the YSP) functionaries as the Peaceful Movement to liberate the South, it had been transformed into an organization of Southern resistance, eager to fight under the state symbols of the former PDRY against, in their wording, northern colonialists plotting to lay their hands on the Hạuramī oil. In 2009, al-Ḥirāk got a new top leader, 'Alī Sālim alBīẹ, former General Secretary of the YSP, a party whose fervent Marxist-Leninist ideology he later renounced in favor of milder social democratic phraseology. The al-Hirāk movement declares that the current conflict in Yemen is nothing but a struggle for control of land and resources between northern kleptocrats and the South with its seventy-five per cent of Yemen's resources. Any agreement that does not give the southern people control of their resources will only provoke a third war between the North and the South, warns al-Hirāk.

To associate oneself with the South means to see in a Northerner an evil alien. A popular joke treats it as follows: "In the South, a school teacher asks: 'Children, who were the People of the Elephant totally destroyed on their way to Mecca and mentioned in the Holy Quran?' - A boy replies: 'Daḥbāshī occupants!" The point is that the boy has confused the Abyssinian intruders of the pre-Islamic time with a pejorative nickname for modern Northerners ("a backward bumpkin"): daḥbāshī instead of aḥbāsh.

Among the most common political slogans used today we find: "Restore the status quo (fakk alirtiba $\bar{a}$ )" and "The South is our Motherland, Aden is our capital." Recent social disasters and tribulations make Southerners re-imagine and re-estimate their history. Now they regard the colonial period and the British Protectorate with a sort of nostalgia reflected in numerous jokes, e.g. about an old woman at the fish market in Aden. She asks: "What is the price for that fish?" A seller replies: "900 riyals." - "Under the British it was two shillings only!" - "Bring back the British and take your fish for nothing!" A joke recorded and published by Helen Lackner $(2017 b, 167)$ embraces all three political periods at once: "Northerner asks: Why do you hate us? Southerner replies: when the British ruled, we hate them, once they left, we loved them. When the socialists ruled, we also hated them, and when they left we loved them; now you are here, we hate you, but we'll love you when you leave."

Local cultural memory is amazingly flexible. Nowadays it appeals to the golden age of the PDRY as if there were no purges, collectivization (known in Haḍramawt as intifädah), permanent shortages of food and goods, etc. In 1994, tribal chiefs did not support 'Alī Sālim al-Bīẹ in his futile efforts to defend al-Mukallā against the northerners. Now, 25 years later, the near future of Hadramawt depends on numerous forces and institutions including local tribal councils and other traditional and modern institutes of restratified society, using various combinations of inherited and acquired statuses. 


\section{Wadi Hadramawt}

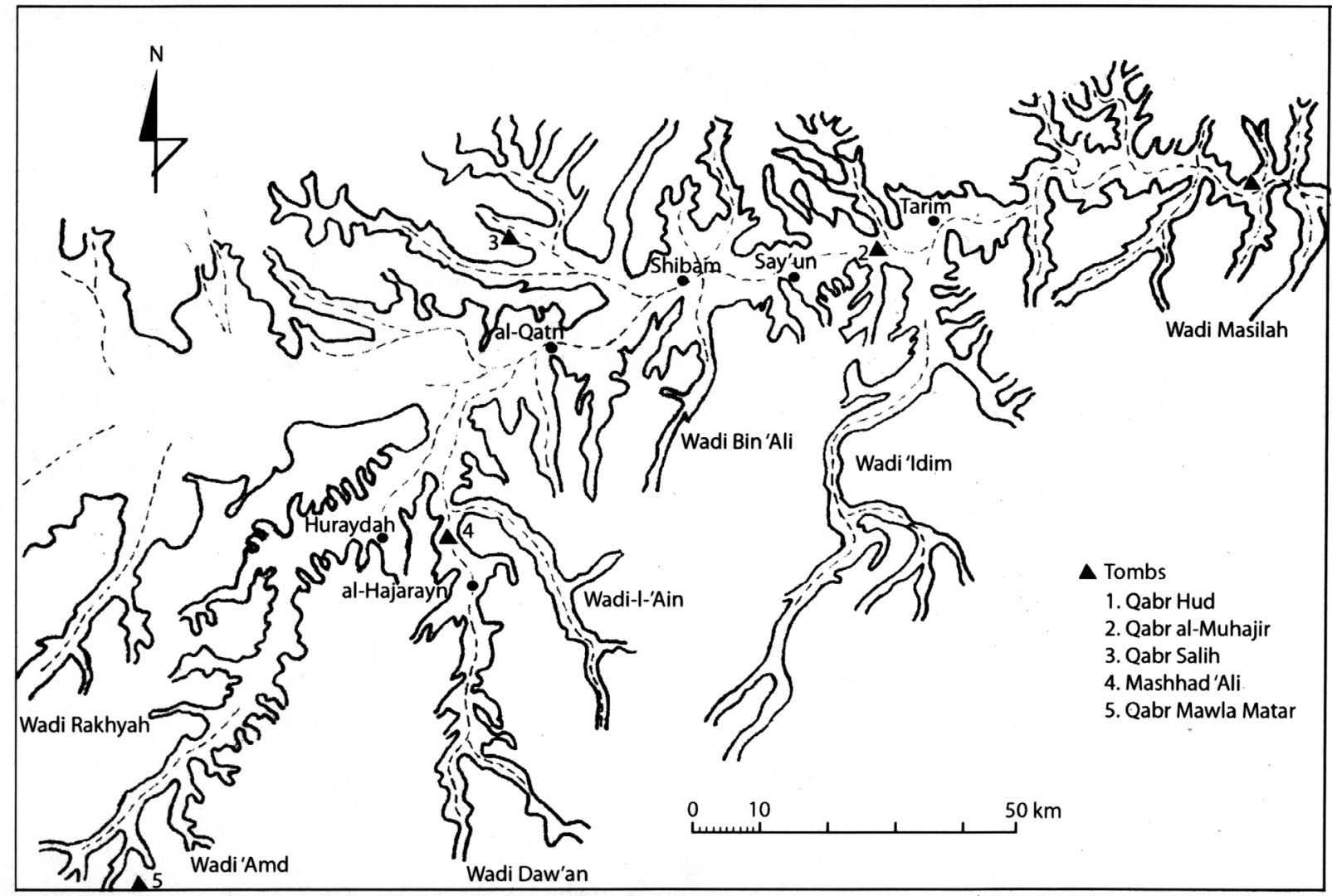

Map: Wādī Hạ̣ramawt. Five most important tombs (qabr - qubūr). Drawn by Mikhail Rodionov.

1) Qabr Hūd, a pre-Islamic prophet;

2) Qabr of Aḥmad b. 'İsā al-Muhājir, the first sayyid who immigrated to the region in the $10^{\text {th }}$ century $\mathrm{CE}$;

3) Qabr Șālih, a pre-Islamic prophet;

4) Mashhad of sayyid 'Alī b. Hasan al- 'Aț̣ās, $18^{\text {th }}$ century CE;

5) Qabr Mawlā Mațar, "the Patron of Rain”, a tribal memorial.

\section{References}

Brandt, Marieke. 2017. Tribes and Politics in Yemen: A History of the Houthi Conflict. London/New York: Hurst/ Oxford University Press.

Brehony, Noel. 2017. Hadhramaut and Its Diaspora: Yemen Politics, Identity and Migration. London: I. B. Tauris. Bujra, Abdallah. 1967. "Political Conflict and Stratification in Hadramaut", Middle Eastern Studies 3:355-75.

— 1971. The Politics of Stratification: A Study of Political Change in a South Arabian Town. Oxford: Oxford University Press.

Camelin, Silvain. 1997. "Reflection on the System of Social Stratification in Hadhramaut." In Hadhrami Traders, Scholars, and Statesmen in the Indian Ocean, 1750s-1960s, edited by Ulrike Freitag and William ClarenceSmith, 147-156. Leiden: Brill. 
Dostal, Walter. 1984. "Squire and Peasant in Tarim". In On Social Evolution: Contributions to Anthropological Concepts, edited by Walter Dostal, 228-232. Vienna: Berger \& Söhne.

1985. Egalität und Klassengesellschaft in Südarabien. Anthropologische Untersuchungen zur socialen Evolution, Vienna: Berger \& Söhne.

Freitag, Ulrike. 2003. Indian Ocean Migrants and State Formation in Hadramawt. Reforming the Homeland. Leiden/ Boston: E. J. Brill.

Ho, Engseng. 2006. The Graves of Tarim. Genealogy and Mobility across the Indian Ocean. Berkeley, Los Angeles, London: University of California Press.

Lackner, Helen. 2017a. "Hadhramaut: Social Structure, Agriculture and Migration." In Hadhramaut and Its Diaspora: Yemen Politics, Identity and Migration, edited by Noel Brehony, 67-84. London: Tauris.

2017b. Yemen in Crisis. Autocracy, Neo-Liberalism and the Disintegration of a State. London: Saqi.

Rodionov, Mikhail. 1993. "The Plateau-and-Valley Complex in Haḍramawt: The Bā Tays Case Study.” In Studies in Oriental Culture and History. Festschrift for Dr. Prof. Walter Dostal, edited by Andre Gingrich, et al., 172-84. Frankfurt/Bern: Lang.

— 1994. "The ibex hunt ceremony in Haḍramawt today." New Arabian Studies 2:124-129.

1996. "Poetry and Power in Haḍramawt." New Arabian Studies 3:118-133.

1997a. "Mawlā Mațar and other awliyā': On Social Functions of Religious Places in Western Haḍramawt." In Mare Erythraeum I., edited by Werner Daum, Walter Dostal, Walter Müller, Walter Raunig et al., 107-114. München: Staatliches Museum für Völkerkunde.

— 1997b. "Poetry from 'Alwa/ Haḍramawt: Self-Identification and Dialogue." In Mare Erythraeum I., edited by Werner Daum, Walter Dostal, Walter Müller, Walter Raunig et al., 115-122. München: Staatliches Museum für Völkerkunde.

1999. "Irrigation in Western Haḍramawt: khayyil as a Social Role." Proceedings of the Seminar for Arabian Studies 29:119-121.

— 2001. "Towards Typology of Visited Shrines in the Wādī Haḍramawt (with special reference to Mawla Matar).” Raydan 7:263-276.

2004. "Mashhad 'Ali Revisited: Documents from Haḍramawt." Proceedings of the Seminar for Arabian Studies 34:307-312.

2005. “'Satanic Matters’: Social Conflict in Madūdah (Haḍramawt), 1357/1938.” Proceedings of the Seminar for Arabian Studies 35:215-221.

2006. "Social Restratification in Modern Haḍramawt." Quaderni di Studi Arabi. Nuova Serie I.: $181-190$.

— 2007. The Western Hadramawt: Ethnographic Field Research, 1983-91. Orientwissenschaftliche Hefte 24, Halle-Wittenberg: OWZ der Martin-Luther-Universität Halle-Wittenberg.

2009. Demoni slov na krayu Aravii. Obshchestvo i stikhotvorstvo Hadramauta [The Demons of words at the Edge of Arabia. Society and versification in Haḍramawt]. St. Petersburg: Nauka Publishing House.

_ 2010a. "Wādī Hậ̣ramawt as a Landscape of Death and Burial." In Death and Burial in Arabia and Beyond. Multidisciplinary perspectives, edited by Lloyd Weeks, 341-45. Society for Arabian Studies Monographs 10.

- 2011. "Contemporary tribal versions of local history in Hadramawt." Proceedings of the Seminar for Arabian Studies 41:333-338.

— 2014. Kulturnaya pamiat i mernaya rech v Yuzhnoy Aravii: Hadramaut [Cultural Memory and Metric Speech at the South of Arabia: Haḍramawt]. St. Petersburg: Nauka Publishing House.

2017. "Le manuscrit no.2179 de Tarīm: tarğama ou autobiographie?" Chroniques du manuscrit au Yémen 24:94-108.

_ 2018a. "Ibādīs in the Cultural Memory of Modern Hậ̣ramawt." In Oman. Ibadism and Modernity, edited by Abdulrahman Al Salimi and Reinhard Eisener, 145-150. Hildesheim, Zurich, New York: Olms.

2018b. "Ibāọ̄is in the written-oral tradition of modern Haḍramawt." Chroniques du manuscrit au Yémen 2:106-116. 
Rodionov, Mikhail, and Hanne Schönig. 2011. The Hadramawt Documents, 1904-51: Family Life and Social Customs under the Last Sultans. Beirut: Ergon.

al-Ṣabbān, 'Abd al-Qādir. 1984. 'Ādāt wa-l-taqālìd bi-l-Ahqāf: mudirīyyat Say'ūn [Customs and Traditions in alAhqaf (=Wādī Hạ̣ramawt): mudiriyyat Say’ūn]. Al-Mukallā.

Serjeant, Robert B. 1957. The Saiyids of Hadramawt. London: The University of London. 


\title{
TRIBES IN THE NEO-LIBERAL ERA: THE TRANSFORMATION OF YEMEN'S SOCIAL STRUCTURE
}

\author{
HELEN LACKNER
}

In recent decades, throughout the world, the dominant neo-liberal ideology has successfully suppressed analysis based on political and economic power relations, despite its considerable relevance to understanding the causes of inequality nationally and internationally. Instead it has encouraged "identity" politics in political action as well as in academic analysis, focusing on issues such as sexuality and gender which obscure the relevance of socioeconomic circumstances in understanding social and political differentiation. In the case of Yemen, for example, this approach has transferred social stratification categories which applied in the precapitalist and precolonial eras to the $21^{\text {st }}$ century while ignoring the impact on these categories brought about by the important underlying political and economic changes of the past century. This has facilitated simplistic explanations which often also imply ethnicist interpretations, suggesting the inferiority of these social categories by comparison with those prevailing in the states of the North, as is frequently seen in the popular and even occasionally the more analytic media.

The term "tribe" is a prime example of the widespread simplistic misuse of an important category as a substitute for serious examination of the country's political economy, as a fourre-tout to define society, rather than attempt to understand the complex social and economic structure of the country at different historical moments, let alone their development over time. Yemeni tribes are labelled premodern by those who want to disparage the country and its people on the one hand, or as a model of perfect social harmony and hive of "democratic" practices where everyone had equal say by those who idealize it. ${ }^{1}$ Significantly, the term "tribal society" has been so widely used that even former president Șālih described Yemen that way. This has encouraged neglect of other social categories either in the past or the present, allowing such misrepresentations as the use of the word "tribal" to describe the Hüthī movement. It has also facilitated an anti-historical approach, ignoring the fundamental changes in modes of production and mechanisms of wealth and poverty creation which have taken place in the past half century.

This chapter outlines some ideas concerning the transformation of Yemeni society in recent decades, focusing on the changing relationship to economic and political power of older and newly emerging social groups and the relevance of the concept of tribe in these relationships. My assumption is that changes in social structure result from fundamental transformations in the underlying relations of control over economic resources, and are therefore the outcome of the synergy between the economy and political

A brilliant caricature of these prejudices was presented by Daniel Corstange in his lecture "Tribes and the rule of law in Yemen" at the Annual Conference of the Middle East Studies Association (MESA) in 2008. 
power. After a brief outline of the country's long-lasting earlier social structure, I focus on two aspects, beginning with those indigenous to the Yemeni policy, including the three periods of recent decades: the Șālih regime, the brief interim transitional period of the post-2011 uprisings and the situation prevailing at the end of the second decade of the $21^{\text {st }}$ century with, on the one hand, the Hüthī-dominated situation in the northern highlands and the emergence of increasing fragmentation elsewhere. The second focus is the involvement of external interventions, particularly those of the internationally funded development community. In conclusion, I raise a few conceptual questions worthy of further discussion.

Throughout any discussion of Yemen, it is important to remember that about $75 \%$ of the country's population are members of tribes, ${ }^{2}$ so when discussing other allegiances/identities, clearly the individuals concerned are also members of ascribed status groups, in most cases, tribes. But they can also be members of professions, political organizations, interest groups, etc. Equally, but not overlapping totally, about $70 \%$ of Yemen's population are still rural, ${ }^{3}$ living in small settlements and villages around the country. Finally it is also essential to recall that there are significant regional differences in both economic circumstances and social structures and therefore most generalizations can be challenged with respect to one area or another: for example, sādah in Hadramawt have cultural characteristics which differ markedly from those of sādah in Șa dah.

Mechanisms for rising in the social structure in societies with "ascribed" status structures have been analyzed in different contexts, particularly that of South Asia, where the caste system is commonly described as permanently unalterable. ${ }^{4}$ In reality, it is possible for individuals and their households to become upwardly mobile: this usually involves gaining some wealth away from their area of origin and then returning to the homeland to a different location where they and their background are not known and they can therefore assert a new status. It is worth pointing out that increased wealth is an almost sine qua non condition to rise in the social structure. Similarly, impoverishment can lead to a lowering of status over a period of time, usually at least one generation.

The situation varied in different parts of the country, and while most of the discussion focuses on the highlands since the middle of the $20^{\text {th }}$ century and on the whole country during the period of Yemeni unity, comparable processes were seen in southern Yemen from the $19^{\text {th }}$ century onwards as migration, particularly from Hadiramawt, was one of the mechanisms which enabled some low-status persons to rise in social rank, mostly by migration to southeast Asia and, in the early $20^{\text {th }}$ century, to Saudi Arabia. Among the most prominent examples are leading business families such as the bin Laden and bin Mahfoudh. During the PDRY period, the process was rather different and, in any case, the regime did not last long enough to be responsible for long-term transformations of social status, which generally take at least a generation, though a few changes were initiated. ${ }^{5}$

2 All figures and statistics about Yemen are subject to considerable challenge. In this particular case, as the constitution states that all citizens are equal, no statistics are ever collected on the issue of the comparative representation of the different ascribed social status groups.

3 The 2012 Statistical Yearbook of the Republic of Yemen (p. 68) gives 71.15\% rural and 28.85\% urban.

4 See Dumont 1974 for lengthy discussion of these issues and probably other more recent papers on both sides of the argument.

5 For an example of social structure changes in Haḍramawt, see Lackner 2017a. 


\section{Social Structure in the Prerevolutionary Period}

Although not static, Yemeni society had certain features which remained stable for many decades, well into the $20^{\text {th }}$ century in the southern protectorates and until the overthrow of the imam's regime in 1962 in the "north." They included in particular a social structure commonly described as being based on ascribed status, i.e. one in which people's social status was inherited, and shifting between one group and the next was formally impossible, though practice was different. The hierarchy was topped by the $s \bar{a} d a h$ (sg. sayyid), sometimes and in some places known as Hashemites or ashräf. They claim descent from the Prophet and their roles are primarily religious and judicial. Until the 1962 Revolution, the northern part of the country was ruled by Zaydi sādah imams, and the main ideological characteristic of the Hūthī movement today is its belief that $s \bar{a} d a h$ have an innate right to rule. Sādah also played a major political role in Haḍramawt. Throughout the country, in addition to their religious and judicial roles $s \overline{a d a h}$ are also landowners. Sädah often, but not always, live in villages where they form the totality or the majority of the population, rather than being dispersed in tribal villages. One notable regional difference is that while sādah in Haḍramawt for example did not bear weapons, those in many other parts of the country did so in the past and still do today. Just below sādah in status are the $q u d \bar{a}^{\prime}$ ( $\left.s g . q \bar{a} d \underline{\imath}\right)$, a group of people whose status was originally achieved through learning and who in the past acted as judges and bureaucrats. They have tribal origins and only became a distinct ascribed social group over centuries of practice.

The vast majority of the population are tribespeople. Unlike other countries where tribespeople in the past were mainly pastoralists, in Yemen the overwhelming majority of tribespeople were settled agriculturalists, primarily owner-cultivators, though some worked as sharecroppers. To deal with another myth, according to which the southern highlands are not tribal, tribes are found throughout the country. The difference resides in the level of political consolidation of tribal units, which ranges from small tribes of a few hundred people covering a village or a district and who are loosely associated with each other through common ancestry, to the well-known major confederations, the Hāshid and Bakīl in the northern highlands and the 'Awlaqī in the southern area. Tribes are the main arms-bearing group and were dominant in society as they were the formal and effective protectors of the rest of the population, both those ranking above and those below them.

Below them are groups considered weak ( $\left.d a{ }^{\text {' }} i f\right) .{ }^{6}$ They are headed by traders, whose status has changed considerably in recent decades, as discussed below. Those who remain comparatively low status include the bani khums, a group which covers artisans of all kinds as well as the less despised among the service providers such as restaurant operators and heralds, who rank above barbers and bloodletters and "henna decorators" among women. Descendants of former slaves, still commonly known as 'abīd were not at the bottom of the hierarchy given that in their former roles they had included both administration and military cadres for the local political leaders, whether tribal or sädah. The lowest status group is that of the akhdām, who now prefer to be described as muhamashin (marginalized), whose status was worsened by a range of prejudices which still prevail today. ${ }^{7}$ Even today, their main occupations are cleaning and begging, though they also occasionally work as casual cash laborers.

6 Distribution of activities and status hierarchies vary considerably for this group. For a useful table with the ranking given by different authors, see Chelhod 1985; Stevenson 1985, 94; Dresch 1989; Weir 2007.

7 Dolores Walters devoted her $\mathrm{PhD}$ thesis to analyzing the comparative levels of low-status groups and attempting to identify the origins of these phenomena, see Walters 1987. 
Formally, all these statuses were abolished in the constitutions following the revolution in 1962 in Șan' $\vec{a}$ ' and independence in the People's Democratic Republic of Yemen in 1967, both of which proclaim equality of all citizens. This explains why no statistics are collected on the distribution of the different social groups today. Economic developments in the past half century have fundamentally changed the country's social structure, in addition to changes within each group, with new families becoming dominant while others have lost their influence.

\section{Domestic Transformation}

\section{The Sălih Period (1978-1990 in the YAR and 1990-2012 in the Republic of Yemen)}

This period, spanning a whole generation, saw the emergence of a capitalist polity on the neo-liberal model prevailing in other Third World states, with the characteristics of this aspect of the globalized world. With limited natural resources, Yemen was an insignificant supplier of raw materials at the world level, but there were enough resources for primary capital accumulation by Yemeni individuals through extraction of the resources: oil and gas from the state, international investments (mainly in the form of development aid from bilateral and multilateral agencies) and trade (of everything from basic food commodities as Yemen imported $90 \%$ of its wheat and $100 \%$ rice, tea and sugar, to household appliances and vehicles), services (particularly telecoms and physical infrastructure), and finally, from the citizens' agriculture and fisheries. In the YAR, remittances from its migrants to the Gulf states in the 1970s and 1980s mainly helped thousands of households to escape poverty, it also both helped shifts in social status for some and contributed to the significant enrichment of a few who benefited directly and indirectly, ${ }^{8}$ by profits on sales of imported goods or even local produce as well as the marketing of produce locally $(q \bar{a} t)$ and internationally (oil, coffee and fish). In all these sectors, a small group of individuals successfully extracted percentages and became the wealthy. Migration, corruption and Șāliḥ's political strategies facilitated this process.

The Sālih regime ensured that profits and income were concentrated under the control of a small rapacious group of kleptocrats whose rise to the top of society was not primarily determined by their ascribed social status, but rather by being Șâlih "cronies," which gave them access to the resources. Thus there was a combination of factors which helped individuals to join the $1 \%$ (or actually less). One of Șālih's strategies to remain in power was to build up support beyond those who might have some "traditional" reason to support him, such as a close relationship within the tribal structure or military loyalty. He supported others to rise from their original status by ensuring their access to resources. Individuals and families who gained power and/or wealth during this period could only do so if allied to Șâlih and cooperating with him and his close associates whether from former leading social groups (sādah and tribes) or from the low-status groups.

Șâlih started implementing this strategy very early on with the establishment of the General People's Congress (GPC) in which he integrated all types of influential people from everywhere in the country, regardless of their ascribed status, thus both giving them social and political recognition in their communities and, at the same time, providing them with opportunities for financial enrichment. He thus established a "modern" entity, a formal political institution which became a party after unification, when

\footnotetext{
8 For the detailed impact on households and mechanisms for shifting from one "ascribed" social group to another, see Carapico and Tutwiler 1981 and Tutwiler 1987.
} 
such organizations became legal, and created it as a base for his power, which transcended ascribed status categories and also permitted members to rise socially, politically and economically through a new institution.

Involvement in the military and security sectors was a particularly important mechanism in this process, and here the tribal element was important as the units he trusted most were composed of men from his own and neighboring tribes, primarily Sanhān and Ānis. One of the mechanisms used was the Military Economic Corporation (later renamed the Yemen Economic Corporation when the IMF and World Bank demanded privatization, although only the name was changed, not the ownership structure).

After unification, in 1990, some of the leaders of the PDRY were absorbed into this group and quickly learned to enrich themselves; prominent examples were Faḍl Muhsin 'Abdullah, ex-minister of trade who profited from major wheat import contracts and Muhammad 'Alī Ahmad, the former governor of the Abyan governorate.

Among the tribal groups or leaders who benefited from their association with Șālih, a few are particularly prominent, such as the al-Aḥmar family of the Hāashid tribal confederation, some of whose members joined the wealthiest in the country and Muhammad Nājī al-Shāyif of the Bakīl confederation, who was a member of the permanent committee of the GPC, thus covering the two major effective tribal confederations. Elsewhere, where no large confederations operated, a more dispersed approach had to be taken, giving positions to members of smaller leading tribal families, for example the Bayt al-Sūfĩ and Bayt Duwayd from Khawlān and Bayt al-Bāshā from Ibb. After unification, local leaders from the southern parts of the country were added: al-Faḍlī, al-Qufaysh and Āl 'Ashāl from Abyan, al- 'Awlaqī from Shabwah, and al- 'Amūdī and Āl Jābir from Ḥaḍramawt.

Most importantly, Șālih also supported the rise of members of other social groups to broaden his political base: civilians from different original ascribed groups rose to both political prominence and wealth through membership of the GPC. Political positions were also a fundamental means of access to wealth, thanks to the widespread and complex corruption structures. Members of famous sādah families achieving senior military and security positions included the al-Waz̄ir, al-Shāmī, al-Kibsī, al-Ahdal, and al- 'Azzānī. From the $q \bar{a} \underline{d} \bar{\imath}$ social stratum, some prominent names include al- 'Arashī and al- 'Ansī from Șan' à', al-Suswah from Dhamār, and al-Iryān̄̄ from Ibb.

Members of the pre-existing trading families, who had in earlier decades been considered among the lower-status groups, transformed their situation as a direct result of the socioeconomic developments of the country in the 1970s and 1980s. During this period, migration to Saudi Arabia and other Gulf States changed the country into one where thousands of ordinary tribespeople entered the cash economy and become traders themselves. As a result of the involvement of the higher social status groups ( $s \bar{a} d a h$ and tribesmen), trade ceased to be associated with low status. Members of the older established trading families, who had in earlier generations moved to British-ruled Aden, now returned to the north and were in a position to provide credit to $s \bar{a} d a h$ and tribesmen, and also expanded into industrial activities and manufacture. But they were only successfully able to retain or improve their positions and status if they were willing to cooperate with Șālị̣ and include his nominees among the management or shareholders of their companies; this was the case, for example, in the enterprises of the best-known families: Hā'il Sa '̄id, Fāhim, al-Ḥabbārī, Thābit, and Bazārah.

While all the above-mentioned groups had previously had either social status or wealth or both, Șālih also promoted and gave opportunities to people from the low-social-status ascribed groups, giving members of these groups opportunities they had not previously had, and thus ensured a far firmer loyalty to himself as the individuals concerned had no other mechanisms on which to rely should they 
fall out of favor. Individuals reaching a high position from these groups include Rashād al- 'Alīmī, Husayn al-Mașwarī and Aḥmad al-Qana' (in 2019 a minister with the Hūthīs). For these individuals and their families, cooperation with Șālih was a mechanism to rise in social status, in addition to the immediate political and economic power they gained.

Overall this process can be described as the emergence of a capitalist class, as was seen in the West in the industrial revolution. Most wealth was obtained through trade, i.e. mercantilism, and transferred to industry, though in the late $20^{\text {th }}$ century, industrialization only played a minor role due to the worldwide economic changes. Corruption, supported by political power, was also a major means towards enrichment for many. By comparison, the US ancestors who gained their wealth and influence in an equally disreputable manner are now known mainly as founders of major philanthropic foundations (Carnegie, Rockefeller, Ford etc.), and in the UK the hereditary landowning aristocratic families have a similar origin, including as warriors rewarded by the king (Marlborough and Bedford are prime examples, but most aristocratic families and "old" wealth in the UK have similar origins).

By the time the revolution of 2011 took place in Yemen, while many of these changes had not yet become fully entrenched, they were well on the way. Younger people did not necessarily remember the social origins of those who had become "big" names in politics and the economy, or the fact that their prominence was less than a generation old. But there was widespread distaste for the corruption associated with Șâlih's associates and "cronies" and with the blatant gap between the public display of wealth of the small minority and the poverty of the majority.

\section{The Transition and the "Rise" of New Social Groups}

By the beginning of this century, rural agricultural households had experienced a significant deterioration of their living standards. Most were tribespeople and had become unable to support their families from their crops and livestock and largely came to depend on the casual labor of their younger (and older) men in the towns and cities, thus suffering a serious loss of social status and self-confidence. Similarly, the members of the new educated professionals, again from most ascribed social groups, such as teachers, medical staff and administrators, could not maintain an acceptable living standard on their salaries, given inflation and routine daily corruption. In addition to calls for real political empowerment, the worsening poverty of the majority was a major cause of the upheavals of 2011.

The 2011 revolutionary movement explicitly called for increased political power for previously marginalized social categories. The uprisings ${ }^{9}$ expressed the demands of the non-privileged bulk of society for empowerment: it was a revolt against the kleptocratic minority which had become extremely wealthy while the majority were finding it increasingly difficult to make ends meet, let alone improve their living conditions, regardless of either their ascribed social status or their more recent economic status. The events of 2011 can, in the current terminology, be summarized as the struggle of the $99 \%$ against the $1 \%$, or the rise of the citizenry challenging the elite. Their demands, if achieved, would bring the political regime in line with the country's constitution, which asserts the equality of all citizens. Their demands included "dignity," a society where citizens would be treated equally, and an end to corruption and nepotism, a society where wa'stah (intermediation, often interpreted to mean

For a discussion of the Arab Spring events throughout the region and including Yemen, see Achcar 2013. 
nepotism) would no longer be the main mechanism to get employment, nor demands for bribes essential to enable people to live reasonably. All these demands were shared widely, regardless of ascribed or "identity" status.

Social media played a very important role in the 2011 movement, but this was mostly differently from the way they are usually described: they allowed rural and urban people to connect within the same movement. They ensured that rural families were fully aware of developments in the towns and cities, not only to be kept informed of the safety of their younger participant members but also enabling them to share and indirectly join in the aims and objectives of the movement. This was a clear reminder to all that most urban residents are simultaneously part-time urban and rural.

The concept of a "national economy" does not necessarily challenge the hegemonic dominant neo-liberal discourse. Its vagueness reflects an absence of alternative economic strategies. Given the importance of the economic crisis, it is surprising that so little effort was invested in identifying a different economic model more able to respond to the needs of the majority of the population, enabling people to earn reasonable incomes; this was one of the main weaknesses of the movement throughout the region and contributed to its later failure.

The youth, women, and civil society were the new "identity-based" social categories which were promoted by the movement and its international supporters. Participants in the movement included thousands of men from tribal and other origins and fewer, but significant numbers of women. Although speakers on the platforms were dominated by "intellectuals" and political leaders, this was a genuine mass movement in which people of all social strata participated on an equal basis expressing social, economic and political concerns unrelated to their status of birth. ${ }^{10}$ It was also an opportunity for the emergence of new social relations as people from the different strata who had previously only had very ritualized relationships based on their respective positions in the status hierarchy learnt to share ideas and discussions. Most importantly, it allowed people from different geographical regions, tribes and status groups to discover common concerns, particularly in the Șan ' $\bar{a}$ ' Square where there was more regional mixing than in other places, where participants were mainly from the same area. But the involvement of different social strata was a phenomenon throughout the country.

Once the uprisings reduced in scope and the country was involved in the UN- and GCC-sponsored transition process (2012-14), the locus for social transformation moved to the institutions of the transition. Here, recognition by the international community (primarily in the shape of the UN) of the importance of these identity-defined forces came in the partially successful efforts to give these groups representation both in the "government of national unity" of the transitional period and, more successfully, at the National Dialogue Conference (NDC). The youth, women and "civil society" were "identity-based" forces which achieved political and social recognition. The NDC was the most successful of these attempts insofar as it was a forum where all the different groups, whether defined by ascribed status or identity, met and discussed: people had to listen and respect each other as individuals addressing whatever issue was under discussion, and could not be ignored because of their "traditional" ascribed status. Whereas international efforts failed to have more than a symbolic impact on the government and most other institutions, in the NDC it succeeded in ensuring $28 \%$ of members were women (instead of the intended $30 \%$ ) and $20 \%$ were young people.

$10 \quad$ See Lackner 2016. 
Of particular relevance here is the way in which the transition addressed issues of representation. Rather than ensuring statistical representation on a regional basis or on that of the different ascribed social strata recognized by all Yemenis, it ensured representation of the "new emerging forces," but these were defined by social identity rather than fundamental economic interests. The groups included in this definition were the previously politically marginalized, namely the youth and women and the muhamashin. A further category of "civil society" was intended to strengthen these and also, given the nature of significant civil society organizations in Yemen, to strengthen representation of highly educated and in many cases, foreign-trained, middle-class individuals who were outspoken and experienced in dealing with the representatives of the international community.

Ultimately, the transitional regime failed to fulfil the hopes expressed by these groups for many of the same reasons it failed in everything else, points I discuss elsewhere. ${ }^{11}$ Symbolic political representation of these groups was insufficient to overcome the vested interests and the power struggle between the main forces during this period, namely Șāliḥ’s GPC and Iṣlāḥ, which represented the political and economic elites. Two main points need to be noted here. First, the primary sector which would have enabled a fundamental social transformation, the economy, needed a sophisticated program maximizing the development of the country's resource assets for the benefit of the majority. This required investments and job creation based on qualifications and competence, a focus on sectors with good economic potential, and other features which could lay the basis for an equitable national economy in a democratic system in the context of scarce natural resources. Real recognition of the political and social importance of the non-privileged social strata, and giving their members the economic means to develop would have had a fundamental impact on the country's political and economic structure, weakening the grip of autocracy and the kleptocrats.

Second, the amalgamation of the youth, women and civil society into a single group attempts to bring together individuals with diverse and sometimes conflicting interests; this was bound to fail due to the absence of shared strategies and objectives. Each of these identity groups was composed of individuals who were also members of other social entities, tribes, sädah, low-status ascribed groups or new professional groups as laborers or professionals. Hence they did not form a cohesive entity and their influence and role depended largely on other aspects of their identity, be they tribal, political or professional. But, had this succeeded, the outcome could have been an increased political role for what is broadly described as the "middle classes," mostly professionals and educated people.

\section{Hūthī Rule and the Return of the Sādah}

Since 2015, the situation in the areas under Hūthī control has marked another turning point. Although capital accumulation has become one of the main raisons d'etre of profiteers of the war economy, and these include members from all the above categories, as well as new ones based on military strength and closeness to the new centers of power, other aspects are of greater social significance, in particular the return to referring to ascribed social status as the main mechanism for empowerment.

The rise of the Hūthīs during the transitional period and since has been marked militarily and politically by a number of characteristics, including authoritarianism and many features of retrograde Islamism,

11 See Lackner 2017b, 39-53. 
particularly with respect to women. Politically, its main manifestation has been the re-emergence of the $s \bar{a} d a h$ as the leading social group, reflecting the Hüthī belief in the innate right to rule of descendants of the Prophet. Among senior Hūthī appointees, the following are outstanding in military affairs: 'Abdullah al-Hākim, a sayyid from Șa dah, appointed head of the fourth military region, head of military security, and most recently head of the Republican Guards; 'Abd al-Qādir al-Shāmī, a sayyid from Ibb appointed Director of Political Security in January 2018; his brother Yahyā al-Shāmī, appointed advisor to the head of military forces in 2016; Yūsif al-Madānī, from Șa 'dah, the husband of Husayn al-Hūthī's daughter, military leader in Tihāmah, appointed early in 2015. Among the many civilians in very senior positions, in addition to members of the Ḥūthī family, the following stand out: Qāḍ̄ Aḥmad 'Abdullah 'Aqabāt, minister of justice; Qāộ̄ Aḥmad Yahyāa al-Mutawakkil, head of the higher Judicial Council; and 'Abd al- 'Azīz Nāṣir al-Kumaym, minister of planning and economic cooperation

The coalition has facilitated implementation of this policy by some of its air strikes: the Saudi bombing of the Ruwayshān funeral commemoration in October 2016 was a particularly prominent moment when the Hūthīs were given the opportunity to replace Șāliḥ senior military appointees by sādah: among the military leaders killed were the head of the Republican Guards ('Alī al-Jāyfĩ) and many other senior military commanders. Disagreement between Șāliḥ and the Hūthīs on the appointment of his replacement remained one of the main issues between the two former allies until Șâliḥ's killing, while many other lower-ranking cadres were replaced by sādah Hüthī supporters, some of whom had few military qualifications.

Other than returning sādah to a situation where they are given privileged positions and political dominance in the regime, while also ensuring that they benefit economically, the only other feature which marks their governance is a very retrograde attitude to women, whose movements they want to control in the same way as other religious fundamentalist movements do. Other than these two features, the Hūthīs have not produced any policies for governing the country differing from those prevailing earlier. The war economy operates as much in the areas they control as elsewhere and their rule is autocratic and certainly more repressive than that of the Șâliḥ regime.

\section{State-Tribe Interaction}

Academic $^{12}$ and political debate about the role of tribes and their relationship to the state ranges widely between two extremes: Some see tribes as entities which, by definition, oppose and compete with the state, while others see tribalism as a mechanism for supporting or complementing the state, as an intermediary institution between the state and village-level communities. Confirming yet again the importance of Ibn Khaldun, most contemporary discussions on the subject return to his analysis, either to support or challenge it. While there have often been tensions between centralized state authorities and the tribes within their territories, in practice, in the past century, the hierarchy seems clear, and tribes operate within the various states around them. ${ }^{13}$ Recently, social anthropologists have adopted very similar interpretations; most prominent among them is Godelier. ${ }^{14}$ In recent centuries, Yemeni

12 See the many important contributions in Khoury and Kostiner (eds.) 1990; Luciani 1990; Jabar and Dawod 2003; Weir 2007.

13 Interpretation confirmed by Weir 2007, 105.

$14 \quad$ Godelier 2004, 296. 
tribes have largely operated in coordination with the state under the imamate and, indeed, during the British colonial period. The two have complementary roles, with tribes providing the armed forces for the state which controls them through hostage keeping (imamate) or the supply of finance and weapons (British protectorates), a system currently revived by the Hūthīs, though not by the internationally recognized government, which has failed to establish its authority in the "liberated" areas.

In recent decades, the complementarity of tribal community level management and central government rule has been manifested in many aspects. The demand by tribal groups and communities for the government to provide the services expected of a modern state, mainly physical infrastructure (roads, telecoms) and social services (medical and education). To obtain these, different types of pressure were exerted, ranging from traditional requests and petitions to more aggressive demand mechanisms such as the kidnapping of tourists and other activities which publicly embarrassed state representatives. Under the Șâlih regime, weapons and violence were used by both tribes and the state, challenging the fundamental belief that the state should have a monopoly on the means of coercion. This was one of the reasons why many condemned the regime for not being a "modern" state. ${ }^{15}$

When convenient, or according to political expediency, state authorities can either take up modern state responsibilities or decline them and tell people to use "tribal" justice; people familiar with Yemen know of innumerable examples and have had experience of being told by modern state officials to use "tribal" mechanisms to solve a problem. These procedures have, however, been endorsed by the official legal system, through law number 32 of 1997 which allows the use of "tribal" compensatory agreements with the agreement of the victims and perpetrator, decisions which are then confirmed in writing by the modern court system. In the early 2000s, Phillips described the situation neatly:

to most tribes, the Yemeni state is an instrument through which a small band of elites exploits and harasses the people. This will not change unless the state delivers benefits and builds trust between itself and grassroots communities. The Yemeni regime has weakened many aspects of the tribal system by co-opting shaykhs with access to wealth and power from the center, thus severing many from their traditional support bases. Shaykhs now often derive their wealth and status from the political center, rather than their traditional constituency in their local area. ${ }^{16}$

Throughout the Șālih period and currently, both state authorities and tribal leaders have manipulated mechanisms to achieve their aims, either claiming the primacy of the state or that of the tribe in a completely opportunistic manner to serve the interests of the moment. For example, in the 2000s, a soldier from Ānis escaped after murdering a tribesman; when the latter's tribe demanded compensation, the Anis tribal leaders refused to take responsibility by responding that "he is the son of the state, nothing to do with us." But when one of their own was killed, they demanded action: Șan 'à' University professor al-Șabrī from Ibb killed a soldier from Ānis in Dhamār. When the tribal leaders came to Șan ' $\bar{a}$ ' intending to take revenge by killing al-Șabrī (who had surrendered to the prison authorities), the state was involved and dealt with the situation by giving the dead soldier a military position so that his family would be compensated by receiving a pension, and ordered the tribal leaders to close the issue.

\footnotetext{
Ben Nefissa et al., 217.

Phillips 2010, 7.
} 
Another example took place in Lahj in March 2017: When an agent of the security forces from the Yāfi' al-Had tribe hit a member of Parliament from Șubayḥah, Șālih 'Alī Farīd al-Barhamī, in the building of the governorate, the latter sought redress in the Parliament. The deputy speaker, Muhammad 'Alī Shaddādī, appointed a three-man team (Sālim Manșūr Haydarah, Fu'ād Muhammad 'Abd alKarīm, and Khālid Șāliḥ al-Radfānī) to address the issue. They then arranged for the problem to be solved "tribally" with the sacrifice of three bulls and other livestock and apologies for the insult. In this case an appeal by the victim to the formal "modern" structure was transformed into a "traditional" tribal issue in the justice system.

\section{External Influences: The Role of "Development" Financiers in Transforming the Social Structure}

Although of infinitely less significance than domestic factors, external ones should not be neglected. Both direct external political involvement since 2011 and earlier development investments or "aid" projects have been instruments used by the North to attempt to direct the nature of change of Yemeni society in recent decades, contributing to bringing to prominence two marginalized groups: women and the akhdàm or muhamashīn. This has had the side-effect of undermining tribal political mechanisms.

Since the 1970s, a series of internationally funded development programs and projects sought to bring about social change. Most of these had detailed strategies aimed at changing the structure and priorities of Yemen's polity. They were implemented by national staff "supported" or, to be more accurate, "directed" by international development experts pushing and promoting the international policies of their funders, whether northern states or multilateral institutions. A few decades ago these would have been described as "social engineering," a term now completely abandoned for "politically correct" reasons, but the actual reality of what was being done continued largely unchanged and involves attempts to influence social and economic change to fit them into a standardized model, currently of neo-liberalism.

The two main transformative policies targeting the country's social structure were first the empowerment of women, promoted particularly in Netherlands-financed projects but also by prominent international financial institutions, particularly the World Bank. Officially claiming to support gender equality, it was also one which was intended to push social transformation in a Western-oriented direction and undermine tribal authority structures. An underlying objective was to slow the rate of population growth which was about $3 \%$ per annum, resulting in a doubling of the population every 20 years.

The second strategy was to insist that projects include all social groups within a community and, in particular, to raise the status of people in the lower social strata by giving them leadership positions. This was correctly perceived as a threat by the existing leaders, usually tribal shaykhs, many of whom benefited from direct support from the state and particularly from elements close to the country's leadership (provided they supported the GPC), whether in line ministries or at governorate level. Despite this opposition, these projects sometimes contributed in a small but significant way, to the spread of the belief that "all are equal" 17 and to empowering these groups A third policy which was resisted was these agencies' intended focus on professionalism and qualifications in recruitment, when they

17 See various IFAD-funded projects, the UNDP Community Based Regional Development Programme, Ali and Baas 2004. 
attempted [in many cases unsuccessfully] to undermine the nepotistic approach to employment. All three of these policies were only very partially implemented due to resistance from the more powerful elements centrally and locally.

With the exceptions just noted, foreign-financed development projects strengthened the tendencies and policies of the state. Both the regime and the financing institutions shared the same prime objectives, namely the implementation of neo-liberal policies, even if the regime did not perceive them in that way. In practice, regardless of rhetoric to the contrary, all implemented policies effectively enriched a small group and worsened the impoverishment of the majority. An important example in agriculture was the development of spate irrigation schemes, the only relatively large schemes possible in Yemen. It is worth noting that the physical and engineering characteristics of spate irrigation infrastructures predetermine outcomes. Even assessments sympathetic to the World Bank confirm the intensification of social differentiation as a result of the Tihāmah spate irrigation projects. ${ }^{18}$ Bonzanigo and Borgia ${ }^{19}$ discuss the projects in Wādī Sihām from the imamate period onwards. Their analysis illustrates the way in which the projects accelerated social differentiation by assisting the more powerful and thus weakening the smallholders, whose access to irrigation water was severely restricted or even completely stopped as a result of the technical "improvements" brought about by the project. Beneficiaries were mainly the original landowners, mostly tribal leaders, but in later decades members of the rising "elites" bought land in anticipation of the works, having had access to the plans and knowing that their value would increase fundamentally.

In summary, the intervention of international development actors did not fundamentally challenge Șāliḥ’s autocratic regime as they shared a philosophy which privileged a small group of wealthy and influential people that included tribal leaders supporting the regime, as well as many security/military elements who were also mostly from tribal backgrounds. But on less fundamental aspects, development agencies promoted social change through the support of two groups, women and poorer people of lower status. They were encouraged to become active participants and beneficiaries of projects as well as community leaders. During the transition, with the open intervention of the UN agencies in procedures, the new "identity-based" approach to social change promoted women and young people. Once the Yemeni politicians took back control of processes, the situation reverted: there is no significant quota of women in the current Yemeni governments, whether internationally recognized or Hūthī, and women have had at best symbolic representation in the formal negotiations between the warring sides since the war started in 2015.

\section{Concluding Remarks}

Tribes and social class overlap and should not be seen as conflicting or mutually exclusive categories. There are many aspects of the changes during recent decades in the role of tribes and in tribal structures which need further study and investigation, placing tribes in their overall historical and social context, nationally and locally. This chapter has presented some of the issues concerning the Yemeni social structure and the place of tribes within different approaches to political economy analysis. The concept of tribe is neither a substitute for, nor in opposition to, analysis based on socioeconomic conditions,;

\footnotetext{
See Ward 2015.

Bonzanigo and Borgia 2009.
} 
rather, it is complementary. Addressing the issue of tribes as social entities is similar to the method used to examine the youth or women, i.e., it focuses on identity rather than on political economy. Tribes had in the past, and continue to have, a potentially important and meaningful social and political role. Tribal solidarity remains a fundamental mobilizing mechanism in Yemeni society. The idea that recent changes "undermine" tribal structures and norms implies that these are static and unable to adapt to new contexts. This is simply not true. As anyone who has been involved in observing any society over a few decades can confirm, so-called "eternal" traditions change fairly rapidly as a result of underlying economic and political transformations. Much anthropological research, regardless of explicit statement by its authors, is interpreted as representing a long-term situation, rather than the actual "moment" of fieldwork as intended by the researchers.

While tribes remain important, given the demographic balance in Yemen, the interaction between tribal leaders and their members has also changed considerably in recent decades as many researchers have demonstrated. In particular, the balance of power within tribes has been affected first by the enrichment of ordinary tribal households through migration in earlier decades and, more recently, by the reassertion of power by tribal leaders who were the direct interlocutors of the state and therefore the mediators for obtaining social goods (physical and social infrastructure) and also household benefits (through employment). This was one of the features of the Șālih regime, which was known as the "city shaykhs" as tribal leaders moved to Șan 'a' to ensure access to material benefits from the regime, thus shifting their role from one of community leadership to being sources of benefits which had to be visited in the same way as state institutions like ministries.

In the Hūthī-controlled areas after 2015, the return to privileging the sādah merely because of their ascribed social status is one reason why the majority of the population oppose them, insofar as the republican ideology of fundamental equality of all citizens has been adopted in principle, while in practice, tribal and other leaders who had gained power under the republican regime reject being relegated to an inferior status. This is the case regardless of the distortions to this ideal implemented by Șāliḥ's autocracy.

There has been a tendency to regard the tribal system as a closed cohesive entity experiencing interference from other social groups, rather than as one element among others of the social landscape which interact with each other over time. Gradually these interactions transform the internal structures of each of the component groups. Just as tribes changed and the relationships of tribal members with each other also changed, complementary changes took place in the roles and positions of other social groups, thus transforming their interrelationships. The current uneasy relationship between the tribes supporting the Hūthī movement and the sādah leadership of the movement is one of many examples of such changes.

\section{References}

Achcar, Gilbert. 2013. The People want. A radical exploration of the Arab Uprising. London, Saqi.

Ali, Ayman Omer; Baas, Stephan. 2004. Rural Institutions and Participation Service. Lessons learned and Good Practice: Community-Based Organizations in Yemen. Șan 'à'/Rome: FAO.

Ben Nefissa, Sara, Maggy Grabundzija, and Jean Lambert (eds.). 2008. La Société Civile au Yémen: Associations et Pouvoir Local, Șan 'à': Centre Français d'Archéologie et de Sciences Sociales, Friedrich Ebert Stiftung.

Bonzanigo, Laura and Cecilia Borgia. 2009. Tracing Evolutions of Water Control in Wadi Siham, Yemen. MSc thesis, Wageningen University, 
Carapico, Sheila and Richard Tutwiler. 1981. Yemeni agriculture and economic change: Case studies of two highland regions, Șan ' $\bar{a}$ ': American Institute for Yemeni Studies.

Chelhod, Joseph. 1985. L'arabie du Sud. Histoire et civilisation 3: Culture et institutions du Yémen, Paris: Maisonneuve et Larose.

Corstange, Daniel. 2008. "Tribes and the rule of law in Yemen." Lecture at the Annual Conference of the Middle East Studies Association (MESA).

Dresch, Paul. 1989. Tribes Government and History in Yemen. Oxford: Oxford University Press.

Dumont, Louis. 1974. Homo Hierarchicus: The Caste System and its Implications. Chicago: University of Chicago Press.

Jabar, Faleh and Hosham Dawod (eds.). 2003. Tribes and Power: Nationalism and Ethnicity in the Middle East. London: Saqi.

Khoury, Philip and Joseph Kostiner (eds.). 1990. Tribes and State Formation in the Middle East. Los Angeles and London: University of California Press.

Lackner, Helen. 2016. “The Change Squares of Yemen: Civil Resistance in an Unlikely Context.” In Civil Resistance in the Arab Spring, Triumphs and Disasters, edited by Adam Roberts, Michael J. Willis, Rory McCarthy and Timothy Garton Ash, 141-168. Oxford: Oxford University Press.

2017a. "Hadramaut: Social Structure, Agriculture and Migration." In Hadramaut and its diaspora, Yemeni Politics, Identity and Migration, edited by Noel Brehony. London: I. B. Tauris.

2017b. Yemen in crisis: autocracy, neo-liberalism and the disintegration of a state. London: Saqi.

Luciani, Giacomo. 1990. The Arab state. Los Angeles and London: University of California Press.

Phillips, Sarah. 2010. Yemen on the Brink: What Comes next in Yemen? Al-Qaeda, the Tribes and State Building. Washington DC: Carnegie Endowment for International Peace.

Republic of Yemen, Ministry of Planning and International Cooperation, Central Statistical Organization 2013: 2012 Statistical Yearbook, Șan'à'.

Stevenson, Thomas. 1985. Social change in a Yemeni highlands town. Salt Lake City: University of Utah Press.

Tutwiler, Richard. 1987. Tribe, Tribute and Trade: Social Class Formation in Highland Yemen. PhD Thesis, State University of New York at Binghamton.

Walters, Dolores 1987. Perceptions of Social Inequality in the Yemen Arab Republic. PhD, New York University.

Ward, Christopher. 2015. The Water Crisis in Yemen: Managing extreme water scarcity in the Middle East. London: Tauris.

Weir, Shelagh. 2007. A tribal order, Politics and Law in the Mountains of Yemen. Austin: University of Texas Press. 


\section{NOTES ON CONTRIBUTORS}

Najwa Adra is a cultural anthropologist with over 30 years of field research and experience in international development. Her doctoral dissertation, Qabyala: The Tribal Concept in Yemen's Central Highlands, examined the emic bases of tribal organization and identity in Yemen. In development, she has worked on projects as diverse as linkages between informal and formal legal systems, changing women's roles in agriculture, adult literacy and intangible heritage. Currently a Visitor in the School of Social Sciences, Institute for Advanced Study, Princeton, New Jersey and associated researcher at the Institute for Social Anthropology, Austrian Academy of Sciences, Najwa Adra is finalizing her book, Tribal Dynamics and Nation Building in Yemen.

Marieke Brandt is a researcher at the Institute for Social Anthropology (ISA) of the Austrian Academy of Sciences in Vienna. Her research focuses on tribalism, tribal genealogy and history, and tribe-state relations in Southwest Arabia. She was a PhD fellow of the Friedrich Ebert Stiftung, DAAD fellow in Sana'a, Marie Skłodowska-Curie fellow of the European Union, and project leader of the New Frontiers Groups Programme (NFG) project "Deciphering Local Power Politics in Northern Yemen" funded by the Austrian National Foundation for Research, Technology and Development. She is the author of the award-winning Tribes and Politics in Yemen: A History of the Houthi Conflict (Hurst/Oxford University Press 2017).

Steven C. Caton is an anthropologist with a focus on the Middle East. He has worked on poetry as a form of political rhetoric in tribal Yemen and is now researching the politics of water scarcity in the Arabian Peninsula. He has also written on film, particularly on the image of T. E. Lawrence. The image is an ideological one, furthering the ends of various political agendas in trans-Atlantic culture. At Harvard, he regularly teaches courses on language and culture; Middle East ethnography; linguistic pragmatics and cultural description; anthropology, cultural studies, and film; and the history of anthropological theory. His books include Peaks of Yemen I Summon: Poetry as Cultural Practice in a Northern Yemeni Tribe (University of California Press 1990), Lawrence of Arabia: a Film's Anthology (University of California Press 1999), and Yemen Chronicle: the Anthropology of War and Mediation (Hill and Wang 2006).

Paul Dresch is an Emeritus research fellow of St John's College, Oxford. He took early retirement from the Institute of Social and Cultural Anthropology in 2013 and is currently working on tribal law manuscripts from Yemen. His books include Tribes, Government and History in Yemen (Oxford, 1989), A History of Modern Yemen (Cambridge, 2000), and The Rules of Barat (Șan ' $\bar{a}$ ', 2006).

Andre Gingrich carried out fieldwork among the Munabbih and other Khawlan al-Sham tribes of North West Yemen, and before that, in Asir and southern Hijaz. He is a fellow of the World Academy for the Advancement of Sciences, a member of the Royal Swedish and the Austrian Academy of Sciences, and was director of the Institute for Social Anthropology at the Austrian Academy of Sciences. 
Helen Lackner studied social anthropology at SOAS and has worked as a development anthropologist in rural areas of over 30 countries during the past four decades. In Yemen she has been involved with projects throughout the country, analyzing the socio-economic conditions of rural communities, and gained a deep understanding of the transformations in social structure during that period under the different political regimes which prevailed since the 1970s. Her latest book is the award-winning monograph Yemen in Crisis: Autocracy, Neo-Liberalism and the Disintegration of a State (Saqi 2017). She is a regular contributor to Arab Digest, Oxford Analytica and Open Democracy.

Lisa Lenz-Ayoub is a $\mathrm{PhD}$ researcher in the discipline of social and cultural anthropology. Her regional focus is the Middle East. She received her bachelor's and master's degrees at the University of Vienna and studied for one year at the Near East School of Theology in Beirut, Lebanon. Lisa has traveled and worked in different projects and positions in other Middle Eastern countries, e.g. in Iran and Oman. Employed at the Institute for Social Anthropology of the Austrian Academy of Sciences, she is currently working on her PhD thesis on the Yemeni-Saudi border from a local tribal perspective.

Mikhail A. Rodionov is a professor of Oriental Studies at St. Petersburg University and chief research scientist of the South and South West Asia Department in the Peter-the-Great Museum of Anthropology and Ethnology, Russian Academy of Sciences. There he got his PhD on the Maronites of Lebanon in 1975 and habilitated on "Traditional Culture of Western Hadramawt" at the Institute for Oriental Studies in 1991. His research and teaching competence comprises comparative religion studies of the Middle East (Druzes, Maronites, Baha'is, Classical \& Modern Islam); history of the Middle East; social, cultural and field anthropology of the Arab world/ and Arab poetry. His field experience includes Syria (1967-68), Egypt (1973), Lebanon (1973 and 2011), Yemen (14 field seasons in Hadramawt, 1983-2008). He is the author of more than 100 scientific presentations, over 220 articles, reviews, translations, and 14 books.

Daniel Martin Varisco is an anthropologist and historian with a focus on Yemen. He conducted ethnographic fieldwork in the central highlands of Yemen in 1978-79, returning throughout the next decade as a development consultant and researcher. He is the president of the American Institute for Yemeni Studies, was a senior fellow at the Institute for Social Anthropology (ISA) of the Austrian Academy of Sciences (2017-2018) working on agriculture and water resource use in Yemen's northern highlands, a senior fellow at the Annemarie Schimmel Kolleg (2019) researching Rasulid-Mamluk relations, and a member of the School for Historical Studies at the Institute for Advanced Study in Princeton (2019-2020).

Alexander Weissenburger holds an MLitt in Middle East, Caucasus and Central Asian Security Studies from the University of St Andrews and an MA in Islamic Studies from the University of Vienna. He currently works as a doctoral researcher at the Institute for Social Anthropology of the Austrian Academy of Sciences and as a lecturer at the University of Vienna. His main research interests are Islamic mobilization and radicalization, Islamic religious and political thought as well as religious minorities of the Middle East. Alexander's PhD project investigates the ideology of the Ḥuthī movement. 


\section{INDEX}

A

al-'Abbasī al-'Alawī, 'Alī b. Muhammad b. 'Ubayd Allāh, 124

'Abd al-'Azīz (King of Saudi Arabia), 114

'abìd, 139, 147

accidental killing (qatl khața '), 67

Aden, 35, 73, 141, 149

'Adnān, 123

'Adnānī tribes, 123, 125, 131

agriculture and tribes, 15, 30, 79-91

agricultural contract (muzāra'ah), 86

agriculture methods development, 83-4

balanced terrace systems, $87-8$

barley (sha $\mathrm{i} r$ ) cultivation, 83,88

cash cropping, $35,79,88$

civil war impact on, 89-90

customary law governance and, $15,79,81,82,84-6$

decline of, $24 n 13,88$

dry farming, 82

during Islamic era, 79

food production and export, 79,88

foreign experts advise for agricultural development, 87

future of agriculture in Northern Yemen, 89-91

grape production, 89

irrigation projects, 156

irrigation system, 79, 82, 84, 85, 87, 88

lack of aid/investment, 80

land rights, 85-6

$q \bar{a} t$ (catha edulis) production, 28, 79, 84, 88, 100

settled farming community, 80

sharecropping, 88

and social structure, $81-2,81 n 3$

socioeconomic change, $88-9$

sorghum (dhurah) cultivation, 82, 83, 83n6, 87, 88

Tihāmah agricultural development and changes, 87-9

traditional crops cultivation, 84

tribal customary and Islamic law, 54, 84-6

water disputes, 86,87

water rights, 85,91

wheat (burr) cultivation, 83,88

ahl al-bayt (sādah/sayyid), 12, 12n11, 23, 39, 42, 68, 73,

$75,81,89,101,121-33,138,147$

al-Ḥūthī (Ḥusayn) envisions for, 126-7

ancestors of, 123
Ḥūthī Movement and re-emergence of, 121-2, 152-3, 157

legitimacy, 124

"Quranic Culture" (thaqāfah qur'āniyyah), 127-8

as religious leadership, 121-2

social structure and, 147

tribal conflicts mediation, 121, 125, 130

and tribal customary law ('urf), 124-5, 132

Ahl Fayfă', 100

Aḥmad (son of 'Alī 'Abdullah Șālị̣), 64

al-Ahmar family, 149

"aid" projects, 155-6

akhdām, 81, 147, 155

al-Akwa', Qadi Ismā̄îl, 53

Āl Sa ūo, 99

Āl Talīd, 71

Āl Thābit, 71

al-Ahjur, 23n10, 24-5, 27, 28, 29

shaykhs of, 24-5, $25 n 15$

'Alī (son-in-law of Muhammad), 23, 121, 127, 127n13

honored Hamdān, 131-2

'Alī Muṣliḥ, Zayd, 126

'Alī Șayyād, Muḥammad b., 66

al- 'Alīmī, Rashād, 66

'Amrān, 68-9

Anșār Allāh. See Ḥūthī Movement (Anșār Allāh/Ḥūthīs)

AQAP (al-Qaeda in the Arabian Peninsula), 140

Arab Spring, 48, 80, 121

Arabian Peninsula, 39, 47, 80, 122

tribal power, $47-9$

Yemen as breadbasket of, 79

artisanal fishing, 30

'Asīr (Saudi province), 111, 112, 114

al- 'Aț̣ās clan, 138

al- 'Ațtās, Mashhad 'Alī b. Ḥasan, 138

authoritarianism, 152

'Awlaqī confederation, 147

'Ayyāsh (tribe)

anti-royalist guerrilla campaigns, 101

as "demilitarized" zone, 104

border management, 15, 96, 97, 98-104

during civil war (1962-70), 101

Philby Saudi border commission (1934), 100-1

Saudi-Yemeni armed conflict (1934), 100-1

states' influence in, 98-101 
tribal section of, $96-8$

under Idrīsī rule, 99

under Ottoman colonial administration, 98-9

\section{B}

B. Mālik, 97, 98, 100, 101

Bā Tays, Fayṣal Khamīs, 140

Bakīl confederation, 25, 80, 111, 112, 147, 149

bālah (poetic genre), 46, 47

“balanced opposition", 13, 13n14

Balghāzī, 112

Banī Hushaysh, 80, 85

Banī Mālik, 112

Banī Mațar, 25

Banū 'Awfān, 101, 102, 104

bar'ah (tribal dance), 31

Barat qawā id, 53, 54n7, 58n18

Barat, Jabal, 53, 53n5, 54, 55, 56, 60n24

barley (sha ìr ) cultivation, 83, 88

Baydā' 'wa-khiyār, 56, 56n14

Bedouin, 79, 80, 81

al-Bīḍ, 'Alī Sālim, 141

Bin Habraysh, Sa 'd b. Hamad, 141

Bin Laden, Osama, 64

Bin 'Ubaydallāh, Rabī' ah 'Awadh, 139

Bin Zinbā', Aḥmad 'Alī, 53, 55, 56

blood debts, 69, 70, 71

blood feud, 65, 66, 70-2, 75-6

See also blood vengeance (tha' $r$ )

blood money (diyah), 64, 65, 67, 68-9, 68n9, 72, 73

blood vengeance (tha' $r$ ), 14-15, 63-76

accidental killing (qatl khata'), 67

$\bar{A} 1$ Talīd Vs. Āl Thābit, 71

al- 'Ușaymāt Vs. Sufyān, 63-4

'Amrān case, 68-9

"black disgrace", 68

blood money (diyah), 64, 65, 67, 68-9, 68n9, 72, 73

as continuation of violence, 70

as controversial concept, 64-6

customary law classification of, 67-8

customary practice of, 66-7, 72, 73, 75

as customary restriction of violence, 67,70

"dilapidation" and "degeneration" process, 64, 72-3

as an honor-bound concept, 66

Islamic jurisprudence discourages blood feuds, 72

longevity of, 69, 70-1

national statistics between civil war (1994) and

"Change Revolution" (2011), 72-3

"negative balanced reciprocity", 66, 70

negative views on, 65-6

politicization of conflict, 64

process of, 66
Qu 'ayțī Vs. Kathīrī, 70-1

reciprocal violence, 70-1, 72

"red disgrace" ( 'ayb ahmar), 68

segmentary theory, 65, 69, 123

"self-help" or freelance revenge, 74

socio-political change impacts, 64

tribal border shifting, 71

tribal conflict resolution, 74-5

tribal customary law and degeneration of, 72-3

vengeance group functions as a blood-money group, 69

"white disgrace" ( 'ayb abyad), 67

willful killing, 68

border communities, 109

active involvement in Yemeni-Saudi border, 111, 112

as border guards, 117

and central government cooperation, 109, 110-11

state-controlled border management and exclusion of, 109, 110, 116, 118

subsidies for, 113, 117

Yemeni-Saudi border guarding role, loss of, 118

See also Yemeni-Saudi border management

Border Guard (haras al-hudūd)

border communities as, 117

and border communities relationship, 110

establishment of, 114, 117

tasks of, 110

Yemeni Border Guard, split of, 116, 118

border shaykhs (tribal leaders)

and central government relationship, 109, 110-12

fled to Saudi Arabia, 116, 117-18

patronage policy, 73-4, 112, 113, 114, 117

subsidies for, 113, 117

tasks changes, 109, 115

See also Yemeni-Saudi border management

border studies, 109-10

border-crossings, illegal, 114, 115

Britain, 71

C

capitalism, 45

cash cropping, $35,79,84,88$

caste system, 146

Central Highland Plateau, 23, 23n10, 24, 27

“Change Revolution" (2011), 13, 15, 66, 72

revolutionary rhetoric, 48-9

Change Square, 48

"city shaykhs", 157

civil society, 16, 79, 82, 90, 151-2

civil war (1962-1970). See Yemen revolution (Sep 1962)

coffee production, 84,88

Cold War era, 15, 103

colonialism, 64, 98-9 
corruption, 87, 90, 148, 149, 150-1

cross-status endogamy, 35

cross-status marriage, 23,31

"cultural intimacy", 33

customary law ('urf), 12, 14-13, 17, 21, 32, 35, 51-62, 100 as adaptive, $27-8$

agricultural activities governance, 15, 79, 81, 82, 84-6

ahl al-bayt and, 124-5, 132

on blood vengeance, $63,66,67-8$

and degeneration of blood vengeance, $72-3$

imamate's dealing with, 124-5

inheritance and trusteeship, 54, 54n7, 55

Kitā $b$ al-ādāb, 52, 52n3, 54, $54 n 7$

Kitāb al-tabyīn, 52-3, 53n6, 60-1

"the law of hospitality", 55-6, 55n12

protector (mujawwir) and protégé (jār) role, 55-8, $55 n 11$

qabyalah as, 26-8

reciprocal protection and protected space, $55-8,55 n 9$

rural areas security maintenance, 27-8, 27n25, 35

and sharī'ah ("Islamic law") relations, 54, 84-6

state-sponsored weakening of, 74, 75

"tribal law corpus", 52

violations of, 28

Zaydī imams condemnation of, 54, 66

\section{D}

Dhofar Province, 47

Dhū Muḥammad, 53, 53n5, 56, 70, 71

"dignity", 150-1

al-Dīn, Sayyid 'Abd al-Karīm Muḥammad Sharaf, 21-2

dīwānīs, 60n25

diyah (blood money), 64, 65, 67, 68-9, 68n9, 72, 73

dry farming, 82

Dutch Rangeland Project, 87

\section{$\mathbf{E}$}

East German Border Guard, 110, 117

education, 34, 35

egalitarianism, 31, 35

Egypt, 113

elections, 35-6

"Empty Quarter", 79

\section{F}

Facebook, 140

Fāṭimah (daughter of Muḥammad), 23, 68n11, 121, $127 n 13$

Fayfā', Jabal, 96, 98, 99, 111

feud. See blood vengeance (tha' $r$ )

food imports, 79, 88

food production and export, 79, 88
G

gender equality, 33-4

genealogy, 14, 16, 17, 22, 22n5, 24, 80, 139-40

General People's Congress (GPC), 148-9, 152

al-Ghādir, Nājīi, 60

Glaser, Eduard, 60, 81

grape production, 89

Greek-Ottoman border management, 110, 117

Gulf War I, 90

\section{H}

Habshūsh, Hayīm, 60

al-Hādī ilā al-Ḥaqq. See Yaḥyā b. al- Ḥusayn b. al-Qāsim al-Rassī (al-Hādī ilā al-Haqq)

Hādī, 'Abd Rabbuh Manșūr, 49, 129

pro-Hād̄̄ Border Guard, 116

Haḍramawt: social stratification, 16, 23, 111, 137-41, 142,147

al-Hirāk association establishment, 141

archaic rituals of ibex hunt, 139

blood vengeance case, 69, 70-1

cultural heritage safeguarding, 140

ex-underprivileged in radical Islamists' organization, 139-40

genealogies of ex-weaklings, 139-40

historical writings by native authors, 140

Irshādī-' Alawī conflict, 138

as a landscape of death and burial, 138

local political attitudes evolution, 141

map of, 142

north-south struggle for land and resources control, 141

oral tradition of, 139

poetry on, 138

shrines and tombs of pre-Islamic prophets, 138, 142

social and cultural identification problems discussions on internet, 140-1

strata hierarchy, 137

Haḍramīs, 16, 138, 140

local political attitudes evolution, 141

social stratification of, 137-41

Hajjah, 79, 111

Hamdān b. Zayd, 12n6

Hamdān tribal confederation, 12, 12n6, 29, 60

tribal integrity of, 29-30

ancient tribe of, 131-2

al-Hamdān̄̄, al-Hasan, 12, 29, 55, 59n23, 80, 91

al-Hamdī, Ibrahim, 35

harìm, 86

"Hashemite", 131, 131n22, 147

Hāshid confederation, 80, 147, 149 
Heiss, Johann, 98

Herzfeld, Michael, 33

hierarchy, 30-1, 65, 81-2, 81n3, 137, 147-8, 149

hijrah, 39, 41, 42, 58, 68, 81

al-Hirāk, 141

homicide, 67-9

types of, 67-8

blood money (diyah), 64, 65, 67, 68-9, 68n9, 72, 73

honor (sharaf), 28, 33, 42, 72, 102, 122, 137

blood vengeance as honor-bound concept, 66

qabyalah as, 28

women and, 28

honor killing, 28, 33

hospitality, 14, 25, 28, 32, 34, 55-6, 55n12

housebuilding, 24, 24n13

household (bayt), 23, 24, 25, 33n36

daymah (household), 24

al-Hūthī family, 75

Ḥūthī Movement (Anșār Allāh/Hūthīs), 13, 15, 75, 117, 103-4, 121-33, 145, 147, 157

ahl al-bayt, re-emergence of, 16, 121-2, 152-3, 157

assassination of Șālih, 64

"Change Revolution" (2011), 13, 15, 48-9, 66, 72

civil war with Saudi/UAE coalition, 49, 75, 89, 116 , $117-18,129$

control over wide parts of the country, 128-9

"Economy of Resistance" (iqtișād al-muqāwamah), 130

emergence of, 16, 116, 121

engagement with tribalism, 130

expansion of, 115-16

inter-tribal relations and conflicts, 122-3

leadership, 15-16, 128, 132

Majlis al-Zaydī al-Islāmī (Zaydī Islamic Council), $129,129 n 18$

mediating in tribal disputes, 130, 132

poetry usage, 131-2

Qaḥțānī and 'Adnān̄i tribes primordial bond, 131

as quasi-indigenous movement, 132

"Quranic Culture" (thaqāfah qur āniyyah), 127-8

religious rule in tribal society, 121-5

school books, changes in, 129

social structure during, 146, 147, 152-3

supporters control over Munebbih, 104

war economy, 129, 152, 153

wars against Yemeni government, 128

weakening of tribal conflict management, 75

Yemen's pre-Islamic heritage, 128

al-Hūthī, 'Abd al-Malik, 128, 130

al-Hūthī, Badr al-Dīn, 128

al-Hūthī, Husayn, 64, 121, 126, 127n15, 130, 132, 133

death of, 126,128

envisions for ahl al-bayt, 126-7
Malāzim Husayn al-Hūthī, 126

"Quranic Culture” (thaqāfah qur'āniyyah), 127-8

I

ibex hunt rituals, 139

Ibn al-Mujāwir, 55

Ibn 'Awfān, 99, 101, 102

Ibn Khaldun, 153

Ibn Miftāh, 85

Ibn Sa 'ūd, 100

“identity" politics, 16, 145

“identity-based" approach, 151-2, 156

"identity-based" forces, 151-2

Idrīsī Period, 99

illegal immigration, 114

"Inclusive Hadhramout Conference" (22 Apr 2017), 141

industrialization, 150

internal displacement, 129

intervention, 27, 27n23, 27n24, 34, 40, 42, 74

irrigation system, 79, 82, 84, 85, 87, 88, 156

Ișlāḥ, 152

Islam, 54, 85

on blood revenge, 72

Sunni Islam, 126

See also ahl al-bayt (Sādah/sayyid); sharī'ah ("Islamic law"); Zaydism

al-Islāmī, Majlis al-Zayd̄̄, 130-1

"Islamic law". See sharī 'ah ("Islamic law")

\section{$J$}

Jabal Munebbih. See Munebbih

Jamous, Raymond, 66, 122-3

al-Jawf, 23, 67, 70, 71, 74, 111, 117

al-Jawhī, Muhammad 'Abdallah, 22-3

al-Jawhiyyin, 140

al-Jawhī, Muhammad 'Abdallah, 22-3

Jeddah, Treaty of (2000), 111, 113-14, 115, 117

Jews, 81,84

jidhn, 53, 53n5

jirbah, 82-4

Jīzān (Saudi province), 111, 112, 114

\section{$\mathbf{K}$}

Kathīrī, 70-1

Kawr Saybān plateau, 138

Khashoggi, Jamal, 64

Khawlān al-Shām tribe, 96, 96n4, 97, 99, 101, 104

Khawlān al-Ṭiyāl tribe, 14, 39, 53, 58, 59, 60, 65

Khawlān bin 'Āmir confederation, 80, 111, 112

"Kindah Society", 139

Kindah tribes, 139

Kyrgyzstan-Tajikistan border management, 110 


\section{$\mathbf{L}$}

land ownership, 31, 32

land rights, $85-6$

law, tribal. See customary law ('urf)

lineage (lahm), 24, 24n11, 25, 80-1

living standards, 150

Local Development Associations, 35

low-status groups, 23, 31, 89, 137, 147, 148, 149, 155

in leadership positions, 155

as shaykhs, 31

\section{M}

Madūdah, 138

Maghrebi law, 51, 54-5, 54n8

Mahra Province, 47

Mahrī (language), 47, 48

Majlis al-Zaydī al-Islāmī (Zaydī Islamic Council), 129, $129 n 18$

Ma'rib dam, 80

marital conformity, 137, 138, 139

Marxist regime, 139

al-Mas 'ūdī, al-Hasan, 29-30

"mawaddah", 121

Mawlā Mațar memorial (Kawr Saybān plateau), 138

mediation, 27, 27n23, 27n24, 34, 40, 42, 74

MENA (Middle East and North Africa), 23, 28, 31n34, 33

"middle classes", 152

Middle East Eye, 116

Middle East

blood vengeance as honor-bound concept, 66

governments interventions in domestic tribal systems, 13

segmentary theory, 65, 69, 123

tribal societies of, 12,16

Military Economic Corporation (later Yemen Economic Corporation), 149

Ministry for State Security (the "Stasi") (East Germany), 110

Ministry of Agriculture, 87

al-Muhājir, Aḥmad b. 'Īsā, 138

Muhammad, descendants of. See ahl al-bayt (Sädah/ sayyid)

Muḥammad, Prophet, 72, 84, 85, 86, 127n14

on agricultural contract, 86

on Muslims sharing things, 85

al-Mukallā, 140

Munebbih tribe, 15, 95-104

'Ayyāsh during civil war (1962-70), 101

'Ayyāsh tribal section, 96-8

'Ayyāsh under Idrīsī rule, 99

border redefinition (1936/7), 100-1, 102
Hūthī supporters control over, 104

inhabitants of, 96-7

intertribal border renewal contracts, 98

intertribal border zones, 96, 98, 102-3

landscape of, 96-7

local situation during current conflict, 96, 104

map, 105

Ottoman colonial administration, 98-9

Philby Saudi border commission (1934), 100-1

Saudi-Yemeni armed conflict (1934), 100-1

Sha'sha' moiety, 97

state agency and state interventions in, 15, 98-102, 103

states as an "auxiliary force", 103, 113

tribe-state relations during Cold War era, 15, 103

tribe-state relations, 15, 95-104

'Uyyūn 'Ayyāsh (thermal springs), 97, 99, 104

Munebbih tribe-state(s) border management, 15, 96, 98-104, 113

Mutawakkilite Kingdom, 87

\section{$\mathbf{N}$}

Najrān (Saudi province), 111, 112, 114

National Dialogue Conference (NDC), 151

"national economy", 151, 152

nationalism, 36, 128

neo-liberal class, 16

rise of, 16,150

neo-liberal era, tribes in, 16, 145-57

neo-liberal ideology, 145

nepotism, 150

New York Post, 64

Northern Highlands (agricultural activities in). See agriculture and tribes

Northern Regional Agricultural Development Project, 87

Nu'mān, Ahmmad Muhammad, 66

\section{o}

Obama, Barack, 64

oil and gas production, 90

"original Arabs", 12

Ottoman period (1538-1635), 63-4, 98-9

Ottomans, 73

border management, 110, 117

colonial administration, 98-9

$\mathbf{P}$

Philby, Harry St. John, 100, 112

Saudi border commission (1934), 101-1

poetry, 14, 26, 28, 31, 33, 33n36, 39, 40, 41, 43, 46

cursed by, 33

genre as a kind of rite of passage, 47

Mahrī poetry, 47, 48 
Nabaț̄ poetry, 47

production rise, 46-7

qașìdah audio-cassettes, circulation of, 46-7

as a vehicle for power, 39, 40, 41, 43

political transition. See social structure, transformation of pre-emption (shuf'ah) right, 85

pro-Hādī Border Guard, 116

"protection right" (jiyār or jiwār $), 55$

\section{Q}

qabyalah (tribalness/tribalism), 11, 13, 14, 16-17, 21-36, 21n3, 111-12, 132, 137, 145, 146

adaptability of, 17

aesthetics of, 31

concept of, 11-12, 16, 122

as cooperation, 25-6

as customary law, 26-8

dialectical terms, 21

duality of, 22, 32, 34

etymology, 21-3

formal ideology and its antithesis, 32-3, 35

as honor, 28

housebuilding, 24, 24n13

implications of, and antithesis to gender roles, 33-4

impossibility of concluding definition, 11-12, 16, 17

inter-tribal relations and conflicts, 122-3

kinship aspects of, 17, 23, 131-2

male representation of, 24, 32

marital relations, 33

models of organization, 35

and "moral equality", 30-1

national public sphere participation, 46

nature of, 80

replacement terms of, $12,12 n 3$

resilience of, 34-6

roots of the term, 11

and sädah or ahl al-bayt relationship, 15-16

segmentary theory, 65, 69, 123

self-expression, restraints on, 32-3

terms usage for tribal groups and divisions, 80

as tribal character and integrity, 29-30

tribal disputes and mediation process, 27, 27n23,

$27 n 24,34,40,42,74$

as tribal organization, $23-5,34$

as tribal origin, 23

work ethic, 30, 35

See also agriculture and tribes; blood vengeance (tha'r); qabyalah: tribal power (tribal leadership); social structure, transformation of; statetribes relationship; state-tribes border management

qabyalah: tribal power (tribal leadership), 14, 39-49

bourgeois public sphere, rise of, 46
"Change Revolution" (2011) revolutionary rhetoric, 48-9

communicative action theory, 46-7

dialectical tension between and within force and persuasion, 42-3

disciplinary/bio-power, 45-6

disputes and mediation process, 27, 27n23, 27n24, $34,40,42,74$

instrumental/coercive type, 41

model of power as persuasion, 40-1, 47-9

notion of power as consensus based on moral suasion, 40,41

past and future on the Arabian Peninsula, 47-9

power as coercion, 40-1

qașidah audio-cassettes, circulation of, 46-7

rhetoric of persuasion, 48

sanctuary and tribes conflict, 39-40, 42-3

skepticism towards notion of power, 44

sovereign power, 45

"symbolic violence", 39-40

theory of discourse and power, 44-7

Van Gannep paradigm of rites of passage, 47

Weberian ideal type of persuasion, 40-1

al-Qaeda, 115

Qahitān (son of Noah and brother of 'Adnān), 12, 80, 123

Qaḥțānī heritage, 132

Qaḥtạnī tribes, 123, 131, 133

qashshām, 84, 84n10, 89

qașìdah, 46-7

Qāsimī, 59, 60

qāt (catha edulis) production, 28, 79, 84, 88, 100

qawā'id, 53

Qu'ayțī, 70-1

al-Qu ayț̣̄, 'Abd al-' Azīz, 71

Quran, 72, 80, 140

\section{$\mathbf{R}$}

Rasulid Era, 79

Rāziḥ, Jabal, 59, 59n22, 65, 98

"realism", 61

reciprocal violence, $70-1,72$

religious intolerance, 32

religious leadership. See ahl al-bayt (Sādah/sayyid)

Republican Guards, 153

revenge taking. See blood vengeance

Rossi, Ettore, 51-3, 54, 54n8, 55, 55n9

Kitāb al-tabyīn, 52-3, 53n6, 60-1

$\mathbf{S}$

Șa dah wars (2004-2010), 63

Sa 'dah, 79, 85, 86, 90, 111, 113

annual rainfall, 82 
grape production in, 89

joint border management affects trade relationships, 115

wādī systems, 86

Sādah/sayyid. See ahl al-bayt (Sādah/sayyid)

Șālih regime, 16, 49, 154, 157

and corruption, 148, 150

social structure during, 16, 146, 148-50

"tribal" compensatory agreements, 154

tribes' strength destruction attempts, 74

Șāliḥ, 'Alī 'Abdullāh, 58, 58n19, 80, 114n4, 153

assassination of, 64, 128

Jeddah, Treaty of (2000), 113-14

modern state building efforts, 73

support for other social groups members rise, 149

See also Șālih regime

al-Samāwī, 86

Șan 'ā' Square, 151

Șan 'à', 48, 10, 1571

agricultural activities in, 79

Hūthīs took control over (2014), 128

Yemeni German Plant Protection Project, 87

Saudi Arabia border management. See Yemeni-Saudi border management

Saudi Arabia, 71

blood money (diyah) offerings to Khashoggi family, 64

bombing campaign, 80, 153

border fence construction announcement, 117

border shaykhs fled to, 116, 117-18

civil war with Ḥuthīs, 49, 75, 89, 116, 117-18, 129

construction of border fortification, 115-16

international border establishment, 112

joint Yemeni-Saudi Border Guard (haras al-ḥudūd) establishment, 114, 117

Ministry of Interior, 114

patronage policy, 73-4, 112, 113, 114, 117

Ruwayshān funeral commemoration bombing (Oct 2016), 153

Saudi-Yemeni armed conflict (1934), 100-1

Saudi Border Guard, 114, 117

Saudi-Yemeni War (1934), 112

Sawt Bā Tays tribe, 140

al-Sayāghī, 86

Saybānī tribal federation, 137

segmentary theory, 65, 69, 123

September Revolution (1962). See Yemen revolution (Sep 1962)

Shajjar am Jalsa, 98, 102

al-Shāmī, Ahmad, 126

sharī'ah ("Islamic law"), 51, 54, 75

on blood feuds, 72 and customary law relationship, 54, 84-6

principles for agriculture, 84-6

water resource usage principles, 85, 91

Sha 'sha' tribal moiety, 97

al-Shāyif, Muḥammad Nājīi, 149

shaykh al-shamal, 98, 99, 101, 102

shaykhs/āqils (tribal leaders), 24-5, 26, 42

blood feud between families, 68-9, 70

"city shaykhs", 157

election of, 25

low-status service provider as, 31

patronage policy, 73-4, 112, 113, 114, 117

on qabyalah as tribal integrity, 29

state-tribes relationship, 73-4, 112

tribal disputes and mediation process, 27, 27n23, $27 n 24,34,40,42,74$

See also border shaykhs (tribal leaders); state-tribes relationship; state-tribes border management

Silsilat al-Yaman wa-ahl al-bayt (al-Islāmī), 130-1

social class and tribes. See social structure, transformation of "social engineering", 155

social stratification. See Haḍramawt: social stratification social structure, transformation of, 16, 145-57

capitalist class, emergence of, 150

complementarity of tribal community level management, 153-4

corruption as mechanisms of, 150-1

development programs and aid projects, 155-6

domestic transformation, 148-50

during PDRY period, 146, 147-8

during Șālị regime, 16, 146, 148-50

external interventions involvement, 146, 155-6

financiers role and, 155-6

"identity" politics, 16, 145

"identity-based" forces, 151-2

"identity-based" social categories, 151

industrialization, 150

low-status groups, 147, 148, 149, 155

mechanisms for rising, 146

migration as mechanisms of, 146, 149

new social groups,

pre-existing trading families, 149

sexuality and gender, 145

social media role, 151

state-tribe interaction, 153-5

transition and rise of, 150-2

UN- and GCC-sponsored transition process (2012-14), 151-2

See also Haḍramawt: social stratification

social transformation. See social structure, transformation of sorghum (dhurah) cultivation, 82, 83, 83n6, 87, 88 
Southern Uplands Rural Development Program (SURDUP), 87

state courts, 28

state-tribes border management, 15, 96, 98-104, 109-10

blood vengeance and tribal border shifting, 71

border communities as border guards, 117

border communities exclusion of, 109, 110, 116, 118

Munebbih tribe-state(s) border management, 15, 96, 98-104, 113

stages of, $110-11$

tribal cooperation and patronage networks, 111-13, 114,117

See also Yemeni-Saudi border management

state-tribes relationship, 13, 15, 16-17, 73-4, 95-104,

$112,153-5$

as an "auxiliary force", 103, 113

"balanced opposition", 13, 13n14

during Cold War era, 15, 103

patronage policy, 73-4, 112, 113, 114, 117

See also state-tribes border management

status, 30-1, 81

Structural Transformation of the Public Sphere, The

(Habermas), 45

Sufyān, 59, 63

Vs. al-'Ușaymāt and, 63-4

Vs. Dhū Muhammad and, 71

Sunni Islam, 126

\section{$\mathbf{T}$}

"T⿳â' if line", 112, 114

Țā' if, Treaty of (1934), 71, 112, 113, 114, 117

Tajikistan-Kyrgyzstan border management, 110

taxation, 99

Tihāmah (coastal zone), 80

agricultural development and change, 87-9

irrigation projects, 156

wādī systems, 86

Tihāmah Development Authority (TDA), 87, 89

trade, 149,150

food production and export, 79, 88

"tribal cohesion", 26

tribal customary law. See customary law ('urf)

tribal icons, 26, 31

tribal identity, 15, 16, 22, 28

See also qabyalah (tribalness/tribalism)

tribal leaders. See shaykhs/āqils (tribal leaders)

tribal leadership. See qabyalah: tribal power (tribal leadership)

tribal membership, 122-3, 122n4

tribal polity, 80

tribal power. See qabyalah: tribal power (tribal leadership) "tribal society". See qabyalah (tribalness/tribalism)

religious rule in, 121-2, 123-5

term, 145

transformation of, 16, 145-57

Tribal Union of Hadiramawt, 141

tribal units, 23-5, 31

lineage (lahm), 24, 24n11, 25, 80-1

mutual responsibilities of tribes and, 25-6

tribal violence. See blood vengeance

tribalism. See qabyalah (tribalness/tribalism)

"tribe" (qabīlah/qabä'il or qubul). See qabyalah (tribalness/tribalism)

tribes and agriculture. See agriculture and tribes

tribe-state border management. See state-tribes border management

$\mathbf{U}$

UAE/Saudi coalition, civil war with Hūthī, 49, 75, 89, $116,117-18,129$

ummah, 127

UNDP (United Nations Development Programme), 87

United Nations (UN), 88, 156

and GCC-sponsored transition process (2012-14), 151-2

United States

"Food for Peace" program, 88-9

Upper Yemen

as home of Zaydism, 121

religious rule in, 121-2, 123-5, 130

'urf. See customary law ('urf)

al- 'Urr (Wādī al-Ahjur), 99

USAID (United States Agency for International

Development), 87

al- 'Ușaymāt, 63-4

'Uyyūn 'Ayyāsh (thermal springs), 97, 99, 104

V

village (mahall), 24, 24n12

gender mixing in, 34

tribal units and tribes mutual responsibilities, 25-6

women's rural economy participation, 33

village endogamy, $25-6,25 n 18$

W

Wādī al-Ahjur, 88, 89

Wādī Masīlah, 138

Wā'ilah tribe, 115

war economy, 129, 152, 153

War on Terror, 127

water crisis, 86,87

water rights, 85, 91

al-Wazīr, Zayd, 126 
West Germany, 110

Western Escarpment, 84, 88

wheat (burr) cultivation, 83,88

women

dependence on male kin, 32, 33

educational opportunities for, 35

freedom of expression, 34

and honor, 28

nafs (women's dance events), 32

political participation and mediation, 27, 27n23, $27 n 24$

role in agricultural system, 87

rural economy participation, 34

social gatherings (tafritah), 33

work ethic of, 30

work ethic, 30

World Bank, 155, 156

\section{Y}

Yaḥyā b. al- Ḥusayn b. al-Qāsim al-Rassī (al-Hādī ilā alHaqq), 123-4, 129-30

"Economy of Resistance" (iqtiṣād al-muqāwamah), 130

Yemen revolution (1967), 23

Yemen revolution (2011), $150-1$

Yemen revolution (Sep 1962), 12, 13, 23, 46, 49, 58, 66, $80,88,112,113,147$

'Ayyāsh (Munebbih) during, 101

Egyptian withdrawal (1967), 101

Saudi and Yemen borderland tribes relations during, 113

Yemeni Border Guard, 114, 116, 118

Yemeni German Plant Protection Project, 87

Yemeni Social Party (the YSP), 141

Yemeni social structure. See social structure, transformation of Yemeni unification (1990), 126, 139, 149
Yemeni-Saudi border management, 15, 99, 102, 109-118 armed conflict in border region (2004), 115-16 border communities as border guards, 117 border fence construction announcement, 117 construction of border fortification, 115-16 current developments at, 116-17

demarcation of boundary, 113-14

international border establishment, 112

Jeddah, Treaty of (2000), 111, 113-14, 115, 117

joint border management, 114, 115-16

joint Yemeni-Saudi Border Guard (haras al-ḥudūd) establishment, 114, 117

landscape of region, 111-12

overlords-states relationships, 111-12

patronage policy, 73-4, 112, 113, 114, 117

Philby Saudi border commission (1934), 100-1

Saudi Border Guard website, 114, 114n5

Saudi-Yemeni armed conflict (1934), 100-1

Sharūrah sector, 114

stages of, 110-11

Ṭà if, Treaty of (1934), 71, 112, 113, 114, 117

Yemeni-Saudi joint committee, 115

YSP (Yemeni Social Party), 141

\section{$\mathbf{Z}$}

al-Zahiri, Mohammed, 35

zāmil (poetic genre), 31, 46, 48

Zaydī imamate, 73, 79, 80, 89, 99, 100, 111n3, 132

Zaydī imams, 54, 73, 80, 100, 147

Zaydī Islam, 123-4, 125

Zayd̄̄ North, 34

Zaydī sādah, 81

Zaydī scholarship, 121, 126

Zaydism, 121, 122, 124-5, 125n10, 130 
